


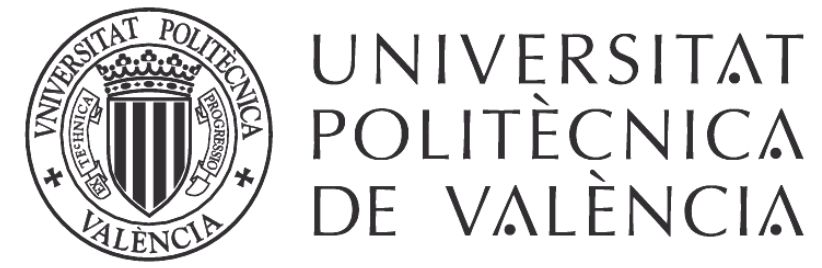

Departamento de Biotecnología

\section{NUEVAS APORTACIONES AL METABOLISMO SECUNDARIO DEL TOMATE. IDENTIFICACIÓN Y ESTUDIO DE MOLÉCULAS IMPLICADAS EN LA RESPUESTA A LA INFECCIÓN CON Pseudomonas syringae pv. tomato.}

Laura Zacarés Sanmartín TESIS DOCTORAL

Directores:

Dra. Ma Purificación Lisón Párraga

Dr. José María Bellés Albert Dr. Vicente Conejero Tomás

Valencia, 2008 
Dña. Ma Purificación Lisón Párraga, Profesor Contratado Doctor del Departamento de Biotecnología de la Universidad Politécnica de Valencia,

D. José María Bellés Albert, Profesor Titular de Universidad del Departamento de Biotecnología de la Universidad Politécnica de Valencia, y

D. Vicente Conejero Tomás, Catedrático de Universidad del Departamento de Biotecnología de la Universidad Politécnica de Valencia,

\section{CERTIFICAN:}

Que la presente memoria titulada "Nuevas aportaciones al metabolismo secundario del tomate. Identificación y estudio de moléculas implicadas en la respuesta a la infección con Pseudomonas sysingae pv. tomato" ha sido realizada por Laura Zacarés Sanmartín bajo nuestra dirección y constituye su Memoria de Tesis para optar al grado de Doctora Ingeniera Agrónoma.

Para que así conste a todos los efectos oportunos, firman el presente certificado en Valencia, a veintinueve de febrero de dos mil ocho. 


\section{AGRADECIMIENTOS}

Son muchas las personas que me han acompañado en esta aventura que inicié hace unos años. Gracias a ellas, en parte, soy lo que soy. Ahora ha llegado el momento de cerrar un capítulo, de pasar página, y no puedo hacerlo sin antes agradecerles todo lo que me han dado...

He realizado este trabajo bajo la dirección de tres CIENTíFICOS con mayúsculas que no sólo me han enseñado Ciencia, sino también lecciones de vida. Gracias, Vicente, por haberme inculcado ese espíritu crítico y esa humanidad que te caracterizan, por escucharme siempre, por tus consejos... Siempre serás un punto de referencia para mí. Gracias, José María, por transmitirme tu buen humor cada día y por ser como eres, una excelente persona. Gracias, mi querida Puri, por haberme enseñado tanto y por haberte implicado de forma incondicional en esta Tesis. Te he admirado siempre, desde el día en que te conocí, y siempre he sabido que llegarías lejos, por tu valía profesional y por tu forma de ser.

No cambio por nada el día a día en el laboratorio, con sus momentos buenos y también menos buenos, pero siempre rodeada de unos compañeros y amigos excepcionales. Gracias, Su, por tu energía, por tu optimismo, por tu buen humor y por tantas otras cosas. Gracias, Mapi por tu gran ayuda, por las divertidas y "sabias" charlas sobre química que hemos compartido, y por tu forma de ser, única y genuina. Gracias Ismael, por tu "ayuda gráfica" incondicional y por el cariño y apoyo que siempre me has mostrado... todo ello denota que "en el fondo" no te caigo tan mal, ¿no? Gracias Emi, ahora tan lejos pero a la vez tan cerca, tú me hiciste el regalo más preciado. Gracias, Cris, por tu dedicación, por tus ganas de aprender, por aportar al laboratorio esa bocanada de aire fresco que tanto nos gusta a todos. Gracias a Ma Carmen ("Chip") y a Mónica ("Chop") por la energía positiva con la que inundáis el laboratorio cada día, y a nuestra última incorporación, Susi, gracias por tu interés y buena disposición.

He podido contar con la ayuda desinteresada de científicos brillantes que han contribuido con sus conocimientos a enriquecer y a mejorar este trabajo. Gracias, Lynne Yenush, por tus sabios consejos y por tu lectura crítica del tan esperado artículo. Gracias, Jaime Primo, por prestarme "tu casa" para desarrollar una parte importante de esta Tesis.

Merecen especial mención todas aquellas personas que hicieron de mi estancia en Estrasburgo una experiencia única y enriquecedora. Gracias, Pierrette, por acogerme tan bien desde el primer día, por tus pequeños pero valiosísimos "trucos", por regalarme tu amistad... y a Sebastian, Alban, Sylvain, Bea y Aurelie por todos los inolvidables "momentos científicos y musicales" que compartimos. Gracias, Michel, por darme la oportunidad de trabajar en tu laboratorio. 
A mis "antiguos vecinos" (Lucrecia, Barto, Victoria, Laia y Miguel), gracias por amenizar los días en el labo, y a mis compañeros Toni, Fede, Jesús, Ainoa, Emilio, Astrid, Laura, Ángela, Regi, Diego, Ma Ángeles, Cinta, Vicente, Pablo, Lina, Noemí, Roberto y un largo etcétera, por hacer agradable mi estancia en este centro.

Esta etapa, como tantas otras, la he compartido con mis amigos Paco, Aurora, Laura, Jaime, Teresa, Germán, Nuria, Carlos, Rebeca, Alberto, Carmina, Marta, Ingo, Diego, Juan Carlos, Liheya, Andrés... a ellos quiero agradecerles los buenos ratos que hemos pasado y que creo seguiremos pasando.

A mi familia, a quien se lo debo todo, GRACIAS por la confianza que han depositado en mí, por el apoyo que me han transmitido y por el cariño infinito que siempre me demuestran. Sobran las palabras...

Y a ti, Corrado, ¿qué puedo decirte?... Gracias por el amor que me demuestras y me has demostrado, por transmitirme fuerza y coraje... por hacer que TODO cobre sentido.

GRACIAS A TODOS 
a Corrado 


\section{RESUMEN}

Los fenilpropanoides constituyen un grupo de metabolitos secundarios producidos y utilizados por las plantas como parte de la respuesta defensiva tanto constitutiva como inducible. Un gran número de ellos están implicados en la resistencia frente a la enfermedad a diferentes niveles: señalización (ácido salicílico), agentes antimicrobianos (fitoalexinas), y endurecimiento de la pared celular (lignina). Las amidas derivadas del ácido hidroxicinámico (HCAAs) son un conjunto de metabolitos, pertenecientes al grupo de los fenilpropanoides, que desempeñan un importante papel en la defensa de las plantas frente a patógenos y predadores. Las HCAAs se forman a partir de la condensación de tioésteres de hidroxicinamoil-CoA con feniletilaminas, tales como la tiramina. El último paso en la biosíntesis de las HCAAs está catalizado por el enzima tiramina hidroxicinamoil transferasa (THT).

En la presente tesis se muestra la identificación y el estudio de cuatro HCAAs, p-cumaroildopamina, feruloildopamina, p-cumaroiltiramina y feruloiltiramina, asociadas a la infección de tomate con la bacteria Pseudomonas syringae pv. tomato. Su identificación y caracterización estructural se han llevado a cabo mediante técnicas de cromatografía líquida de alta resolución y espectrometría de masas (HPLC-MS). Se ha analizado la posible implicación del ácido salicílico y del etileno en la inducción patogénica de dichas moléculas y del enzima responsable de su biosíntesis (THT). Además, se ha estudiado la actividad antioxidante y antibacteriana in vitro de las cuatro HCAAs identificadas. Por último, se han obtenido líneas transgénicas de Arabidopsis thaliana y de tomate que sobreexpresan el gen de la THT, y se han analizado los perfiles cromatográficos de dichas líneas. 


\section{RESUM}

Els fenilpropanoids contituixen un grup de metabolits secundàris produïts per les plantes i formen part de la resposta defensiva tant constitutiva com induïble. Un gran nombre d'ells sòn implicats en la resistència contra l'enfermetat a diferents nivells: senyalització (àcid salicílic), agents antimicrobians (fitoalexines), i enduriment de paret cel.lular (lignina). Les amides derivades de l'àcid hidroxicinàmic (HCAAs) sòn un conjunt de metabolits, que pertanyen al grup dels fenilpropanoids, els quals exercixen una funció molt important en la defesa de les plantes contra patògens i predadors. Les HCAAs es formen a partir de la condensació de tioèsters de hidroxicinamoil-CoA amb feniletilamines com la tiramina. La última etapa de la biosíntesi de les HCAAs és catalitzada per l'enzim tiramina hidroxicinamoil transferasa (THT).

En este treball es presenta l'identificació i l'estudi de quatre HCAAs, $p$ cumaroildopamina, feruloildopamina, $p$-cumaroiltiramina i feruloiltiramina, associades a la infecció de la tomata amb la bactèria Pseudomonas syrinage pv. tomato. La seua identificació i caracterització estructural s'han portades a terme mitjançant tècniques de cromatografia líquida d'alta resolució i espectrometria de mases (HPLC-MS). S'ha analitzat la possible implicació de l'àcid salicílic i de l'etilé en la inducció patogènica de les esmentades molècules i de l'enzim responsable de la seua biosíntesi (THT). A més a més, s'ha estudiat l'activitat antioxidant i antibacteriana in vitro de les quatre HCAAs identificades. Finalment, s'han obtingut línies transgèniques que sobreexpressen el gen de la THT, i s'han analitzat els perfils cromatogràfics en estes línies. 


\begin{abstract}
Phenylpropanoid compounds are widely used by plants as a part of the antimicrobial defense arsenal. A number of these products have been implicated in disease resistance playing different roles: signaling (salicylic acid), antimicrobials, and plant cell wall reinforcement. Among them, hydroxycinnamic acid amides (HCAA) constitute an important group that has been implicated in the plant defense to both pathogens and insect attack. HCCA are formed by the condensation of hydroxycinnamoy-CoA thioesters with phenylethylamines such as tyramine. The last step in tyramine-derived HCAA biosynthesis is catalized by hydroxycinnamoylCoA:tyramine N-(hydroxycinnamoyl) transferase (THT).

Here we report the identification and characterization of four HCAA, $p$ coumaroyldopamine, feruloyldopamine, p-coumaroyltyramine and feruloyltyramine, induced in tomato plants upon Pseudomonas syringae pv. tomato infection. Their identification and structural characterization have been made by MS-HPLC techniques. We also have explored the implication of ethylene and salicylic acid on HCAA accumulation. Antimicrobial and antioxidant in vitro studies have been performed using the four synthesized amides. Additionally, we have obtained transgenic Arabidopsis thaliana and tomato lines overexpressing THT. Changes in the metabolic profile of the overexpressing THT lines compared with wild-type are analyzed.
\end{abstract}


ACC 1-aminociclopropano-1carboxílico

$\mathrm{ACO}$

ACS

ADS

AOC

AOS

AVG

BA2H

$\begin{array}{ll} & \text { hidroxilasa } \\ \text { BHT hidroxitolueno butilado }\end{array}$

CD

CEVd

CT

DCC dicilohexilcarbodiimida

DPPH 2,2-difenil-1-picrilhidracil

DMAPP dimetilalil pirofosfato

eds 16

ES+

ES-

ET

FD

FT

$g$

GA

GUS

HCAAs
ACC oxidasa

ACC sintasa

$S$-AdoMet sintasa

óxido aleno ciclasa

óxido aleno sintasa

aminoetoxi-vinilglicina

p-cumaroildopamina

viroide de la exocortis de

los cítricos

$p$-cumaroiltiramina

enhnaced disuade

susceptibility16

electro-spray positivo

electro-spray negativo

etileno

feruloildopamina

feruloiltiramina

campo gravitatorio

unitario

ácido gentísico

$\beta$-glucuronidasa

amidas derivadas del

ácido hidroxicinámico
HPLC cromatografía líquida de

alta resolución

HPLC-MS cromatografía líquida de

alta resolución y

espectrometría de masas

acopladas

hpi horas post inoculación

hpt horas post tratamiento

HR respuesta hipersensible

ICL isocorismato piruvato

liasa

ICS isocorismato sintasa

IPP isopentenil pirofosfato

ISR resistencia sistémica

inducida

JA ácido jasmónico

LAR resistencia local

adquirida

LOX lipoxigenasa

LRR leucine rich repeat

MeJA metil jasmonato

MS espectrometría de masas

nos nopalina sintasa

NPR1 non-expressor of PR1

OPDA ácido12-oxo-fitodienoico

PAMPs Pathogen-Associated

Molecular Patterns

PCR reacción en cadena de la polimerasa 


\begin{tabular}{|c|c|}
\hline PAD & photodiode array \\
\hline & detector \\
\hline PCR & reacción en cadena de la \\
\hline & polimerasa \\
\hline PINs & inhibidores de proteasas \\
\hline PLA & fosfolipasa $\mathrm{A}_{2}$ \\
\hline PRs & Pathogenesis-Related \\
\hline & Proteins \\
\hline ROS & especies reactivas de \\
\hline & oxígeno \\
\hline RPL2 & proteína ribosomal L2 \\
\hline RT-PCR & transcripción reversa de \\
\hline & RNA seguida de PCR \\
\hline $\mathbf{S A}$ & ácido salicílico \\
\hline$S$-AdoMet & $S$-adenosil-metionina \\
\hline SAR & resistencia sistémica \\
\hline & adquirida \\
\hline SID2 & Salicylic-Acid-Induction \\
\hline & Deficient2 \\
\hline TD & deaminasas de treonina \\
\hline THF & tetrahidrofurano \\
\hline TMS & tetrametilsilano \\
\hline TMV & virus del mosaico del \\
\hline & tabaco \\
\hline ToMV & virus del mosaico del \\
\hline & tomate \\
\hline TYDC & tiramina descarboxilasa \\
\hline
\end{tabular}




\section{ÍNDICE}

\section{Introducción}

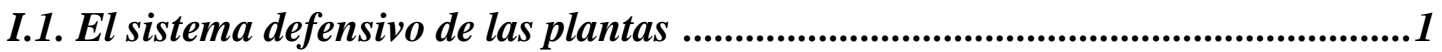

I.1.1. Consideraciones generales ................................................................. 1

I.1.2. La percepción del patógeno ....................................................................5

I.1.2.1.- El reconocimiento inespecífico: elicitores o PAMPs. ...............5

I.1.2.2. - El reconocimiento específico: la interacción gen a gen .............6

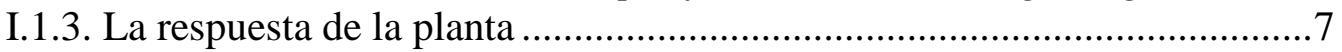

I.1.3.1.- Las respuestas defensivas locales.........................................

I.1.3.2.- Las respuestas defensivas sistémicas......................................10

I.1.4. Las rutas de señalización de la respuesta defensiva en la planta ..............12

I.1.4.1. La ruta del ácido salicílico (SA) ............................................ 12

I.1.4.2. La ruta del ácido jasmónico (JA)............................................ 16

I.1.4.3. La ruta del etileno (ET)........................................................... 19

I.1.4.4. Interacciones entre las rutas de señalización patogénica ........22

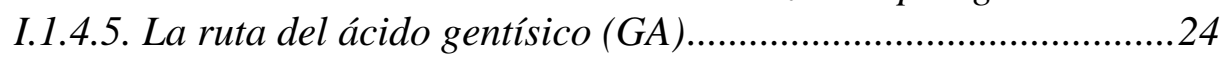

I.2. El metabolismo secundario en el sistema defensivo de las plantas ...................26

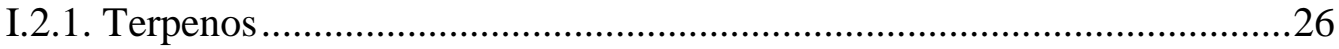

I.2.1.1. Biosíntesis de los terpenos ......................................................22

I.2.1.2. Los terpenos en el sistema defensivo de las plantas ................29

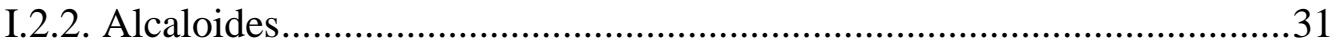

I.2.2.1. Biosíntesis de los alcaloides........................................................ 31

I.2.2.2. Los alcaloides en el sistema defensivo de las plantas................34

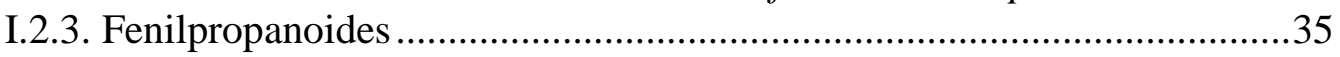

I.2.3.1. Biosíntesis de los fenilpropanoides: la ruta del ácido

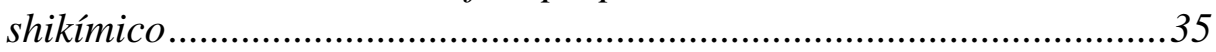

I.2.3.2. Metabolismo de las amidas derivadas del ácido

hidroxicinámico: fisiología y bioquímica...............................................39

I.2.3.3. Los fenilpropanoides en el sistema defensivo de las plantas: importancia de las HCAAs ......................................................44

II. Objetivos ................................................................................................. 47

III. Materiales y Métodos ............................................................................. 49

III.1. Material vegetal, condiciones de cultivo y tratamientos ..............................49

III.2. Inoculación del material vegetal y recogida de muestras.............................50

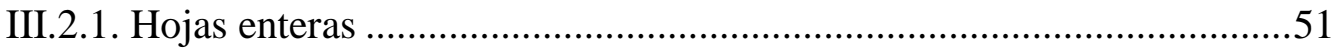

III.2.2. Manchas necróticas y zona alrededor de las mismas ............................51 
III.3. Extracción de compuestos fenólicos ...........................................................52

III.3.1. Compuestos fenólicos libres ..........................................................5 52

III.3.2. Compuestos fenólicos conjugados ..................................................52

III.4. Aislamiento y purificación de ácidos nucleicos de plantas ...........................54

III.4.1. Transformación de Escherichia coli ....................................................54

III.4.2. Purificación de plásmidos bacterianos ...................................................54

III.4.3. Aislamiento y purificación de RNA de plantas.....................................54

III.4.4. Reacciones de amplificación (RT-PCR) .............................................54

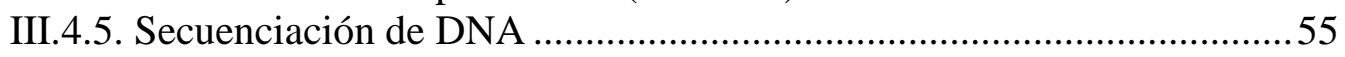

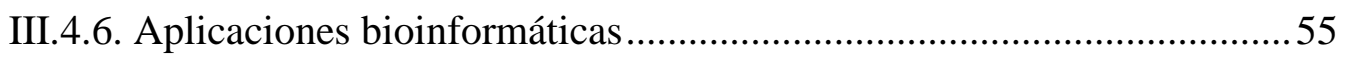

III.5. Técnicas de análisis, síntesis, cuantificación e identificación de

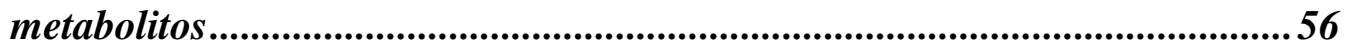

III.5.1. Análisis y cuantificación de las muestras por cromatografía

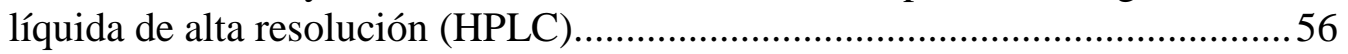

III.5.2. Análisis de la producción de etileno mediante técnicas de

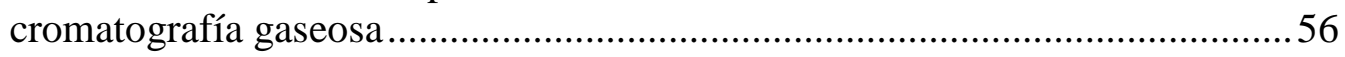

III.5.3. Identificación de metabolitos mediante cromatografía líquida de lata resolución y espectrometría de masas acopladas (HPLC-MS) ...................57

III.5.4. Síntesis de las HCAAs .....................................................................5 57

III.5.5. Elaboración de curvas patrón de las HCAAs para su

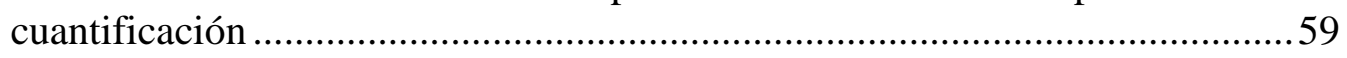

III.6. Ensayos de actividades in vitro de las HCAAs................................................60

III.6.1. Ensayo de la actividad antibacteriana in vitro....................................60

III.6.2. Ensayo de la actividad antioxidante in vitro ......................................... 60

III.7. Obtención de plantas transgénicas..........................................................61

III.7.1. Obtención del cDNA del gen THT1-3 de tomate.................................61

III.7.2. Fusión de la región directa del gen THT1-3 al promotor doble

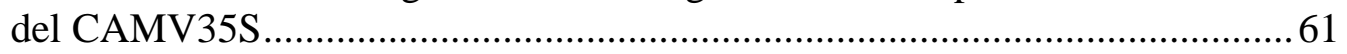

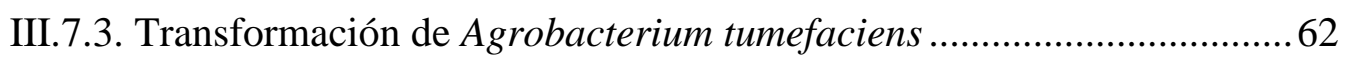

III.7.4. Transformación genética de plantas de Arabidopsis thaliana ............... 62

III.7.5. Transformación genética de plantas de tomate ......................................63

III.7.6. Estudios in situ de la actividad $\beta$-glucuronidasa ..................................63

IV. Resultados y discusión ........................................................................65

IV.1. Caracterización de cuatro amidas derivadas del ácido hidroxicinámico en tomate 'Rutgers' infectado con Pseudomonas syringae pv. tomato.

IV.1.1. La infección de plantas de tomate 'Rutgers' con la bacteria Pseudomonas syrinage pv. tomato induce la acumulación de cuatro compuestos de naturaleza fenólica..... 
IV.1.2. Estudio de los espectros de masas y de absorbancia de los compuestos 1, 2, 3 y 4 inducidos por la infección de Pseudomonas syrinage pv. tomato

IV.1.3. Acumulación de las HCAAs en tomate infectado con

Pseudomonas syringae pv. tomato.....

IV.2. La inducción de la tiramina hidroxicinamoil transferasa (THT) precede la acumulación de $C D, F D, C T$ y FT.

IV.3. Estudio de la posible implicación del ácido salicílico (SA) y del etileno (ET) en la inducción patogénica de las HCAAs.

IV.3.1. La activación de la síntesis de las HCAAs sigue una vía independiente de SA.

IV.3.2. El etileno es esencial para la inducción de la expresión del gen $T H T$ y para la acumulación de las HCAAs

IV.4. CD y FD poseen actividad antioxidante

IV.5. CD y FD poseen actividad antibacteriana .

IV.6. Sobreexpresión del gen de la tiramina hidroxicinamoil transferasa (THT) en plantas transgénicas

IV.6.1. Arabidopsis thaliana como sistema modelo para la sobreexpresión de la THT

IV.6.1.1. Obtención de plantas transgénicas ..........................................93

IV.6.1.2. Estudio de la acumulación de HCAAs en plantas 35S2X::THT::nos de Arabidopsis thaliana ...........................................95

IV.6.2. Sobreexpresión de la THT en plantas de tomate Solanum lycopersicon cv. UC82

IV.6.2.1. Obtención de plantas de tomate portadoras de la construcción 35 S2X::THT1-3::nos

IV.6.2.2. Estudio de la acumulación de HCAAs en plantas 35S2X::THT1-3::nos de tomate

VI. Bibliografía.................................................................. 105

Anexos................................................................................. 133

Anexo I. Zacarés, L., López-Gresa, M.P., Fayos, J., Primo, J., Bellés, J.M., and Conejero, V. (2007) Induction of p-coumaroyldopamine and feruloyldopamine, two novel metabolites, in tomato by the bacterial pathogen Pseudomonas syringae Mol. Plant Microbe Interact. 20(11):1439-1448. 


\section{ÍNDICE DE FIGURAS, TABLAS Y ESQUEMAS}

\section{Introducción:}

Figura 1. Diferentes tipos de ataque por agentes estresantes bióticos que afectan a las diversas partes de la planta ................................................ 2

Figura 2. Naturaleza multicomponente de la respuesta defensiva ............................ 4

Figura 3. Modelo ilustrativo del sistema inmunológico de las plantas ...................... 7

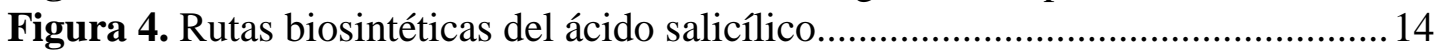

Figura 5. Ruta de biosíntesis del ácido jasmónico .................................................... 17

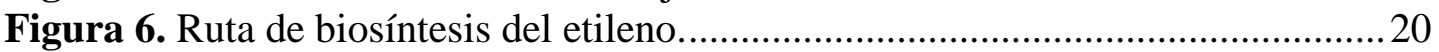

Figura 7. Interacción entre las diferentes rutas de señalización patogénica...............23

Figura 8. Biosíntesis compartimentada del IPP y del DAMP .................................28

Figura 9. Alcaloides de plantas con diversos orígenes biosintéticos..........................32

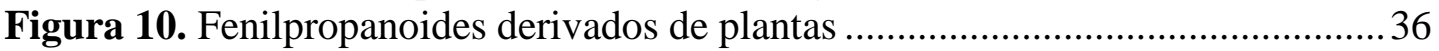

Figura 11. Metabolismo de los fenilpropanoides ................................................... 38

Figura 12. Estructura química de algunas amidas derivadas del ácido hidroxicinámico (HCAAs) de plantas ..................................................... 41

Figura 13. Biosíntesis de la feruloiltiramina a partir de tirosina ..............................43

Tabla 1. Interacción de GA y SA en diferentes interacciones planta-patógeno .........25

\section{Materiales y Métodos:}

Figura 14. Conjugación de compuestos fenólicos en forma de $\alpha$ y $\beta$ glucósidos

Figura 15. Mecanismo de reacción de la síntesis química de las HCAAs ................58

Figura 16. Curvas patrón para cada una de las HCAAs ..........................................59

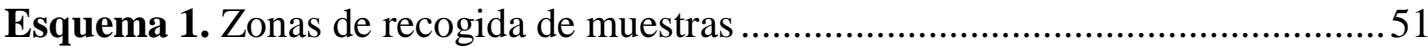

Esquema 2. Construcción pBI121::GUS::35S2X::cDNA::nos ................................62

\section{Resultados:}

Figura 17. Plantas de tomate 'Rutgers' infectadas con la bacteria Pseudomonas syringae pv. tomato

Figura 18. Análisis por HPLC de los extractos metanólicos de hojas de tomate 'Rutgers'

Figura 19. Espectros de masas y de absorción en el UV relativos al compuesto 1

Figura 20. Espectros de masas y de absorción en el UV relativos al compuesto 2

Figura 21. Espectros de masas y de absorción en el UV relativos al compuesto 3 ..... 
Figura 22. Espectros de masas y de absorción en el UV relativos al compuesto 4

Figura 23. Patrón de acumulación de $p$-cumaroildopamina (CD), feruloildopamina (FD), $p$-cumaroiltiramina (CT) y feruloiltiramina (FT) en tomate 'Rutgers' infectado con Pseudomonas syringae.

Figura 24. Niveles de acumulación de las cuatro HCAAs en distintas zonas de las hojas de tomate 'Rutgers' infectadas con la bacteria Pseudomonas syringae.

Figura 25. Patrón de acumulación de THT .

Figura 26. Análisis de compuestos fenólicos en plantas de tomate $N a h G$ infectadas con la bacteria Pseudomonas syringae pv. tomato.

Figura 27. Efecto del AVG en la acumulación de $p$-cumaroildopamina (CD), feruloildopamina (FD), $p$-cumaroiltiramina (CT) y feruloiltiramina (FT) y del transcrito THT, en plantas de tomate 'Rutgers' infectadas con Pseudomonas syringae pv. tomato

Figura 28. Efecto del tratamiento con etileno en la inducción del mRNA de la THT y la acumulación de $p$-cumaroildopamina (CD), feruloildopamina (FD), $p$-cumaroiltiramina (CT) y feruloiltiramina (FT), en plantas de tomate 'Rutgers'

Figura 29. Ensayo de la actividad antibacteriana de $p$-cumaroildopamina (CD), feruloildopamina (FD), p-cumaroiltiramina (CT) y feruloiltiramina (FT)

Figura 30. Acumulación de At2g39030 en hojas de Arabidopsis infectadas con la bacteria Pseudomonas syringae ....

Figura 31. Acumulación del mRNA del isoenzima THT1-3 en las líneas transgénicas de Arabidopsis 1, 2, 3, 4 y 5.

Figura 32. Análisis de la acumulación de compuestos fenólicos en las líneas transgénicas de Arabidopsis thaliana

Figura 33. Ruta biosintética del ácido sinápico

Figura 34. Acumulación del mRNA del isoenzima THT1-3 en las líneas transgénicas de tomate $11.1,11.2,12.3,34.1,35.1$ y 38.1 , y en dos controles no transgénicos

Figura 35. Niveles de acumulación de p-cumaroiltiramina en las líneas transgénicas $11.1,11.2,12.3,34.1,35.1$ y 38.1 comparadas con las líneas control (C1 y $\mathrm{C} 2)$

Tabla 2. Cuantificación de la capacidad antioxidante in vitro de $p$ cumaroildopamina (CD), feruloildopamina (FD), $p$ cumaroiltiramina (CT) y feruloiltiramina (FT), y de sus precursores (ácidos cumárico y ferúlico, tiramina y dopamina) 
I. Introducción 


\section{Introducción.}

\section{I.1.- El sistema defensivo de las plantas.}

\section{I.1.1.- Consideraciones generales.}

Las plantas están continuamente expuestas a una gran diversidad de agentes estresantes y situaciones de estrés potenciales. Por ello, han desarrollado a lo largo de la evolución mecanismos de defensa muy eficaces, y por lo tanto, el establecimiento de la enfermedad suele ser más la excepción que la norma (figura 1).

Estos mecanismos de defensa incluyen tanto barreras físicas y químicas (resistencia pasiva), como una serie de reacciones (resistencia activa), que se inducen como consecuencia de la invasión patogénica, confiriendo a las plantas lo que se denomina resistencia adquirida. La resistencia pasiva la componen una serie de elementos constitutivos, algunos de naturaleza estructural, como la topografía de la superficie vegetal, la composición y estructura de la cutícula, estructura de los estomas, pared celular, etc., mientras que otros son de naturaleza química. Se trata en este último caso de compuestos que pueden ser directamente tóxicos para el patógeno (compuestos fenólicos, lactonas no saturadas, derivados sulfurados, saponinas, proteínas de defensa, entre otros) o que existen en la planta en forma de precursores no tóxicos a partir de los cuales se libera la forma tóxica cuando se produce la infección (por ejemplo, liberación de ácido cianhídrico a partir de cianógenos) (Conejero et al., 1990; Baker et al., 1997; Pieterse et al., 2001; Staal y Dixelius, 2007).

La resistencia activa puede ser inducida de forma específica, y va normalmente acompañada de la muerte celular, dando como resultado el confinamiento del patógeno a las zonas necróticas, lo que constituye una interacción incompatible denominada respuesta hipersensible (HR). La respuesta defensiva puede ser también de tipo compatible. En este caso no tiene lugar la muerte celular, aunque, como ocurre en la HR, se activan una batería de señales que también pueden ser liberadas frente a estreses de naturaleza biótica o abiótica. En las interacciones compatibles, la enfermedad se extiende a toda la planta (Conejero et al., 1990; Dixon et al., 1994; Bent, 1996; Ryals et al., 1996; Staal y Dixelius, 2007). 




Figura 1. Diferentes tipos de ataque por agentes estresantes bióticos que afectan a las diversas partes de la planta. 
Además de la de muerte celular, en la reacción hipersensible se producen, como parte de la respuesta defensiva, unos compuestos antimicrobianos de bajo peso molecular denominados fitoalexinas. Se trata de las primeras armas moleculares antimicrobianas de las que se tuvo conocimiento. Estos mecanismos de resistencia local adquirida $(L A R)$, en torno a las células muertas, también se activan en tejidos alejados, por medio de una señal o mensaje que media la activación de reacciones defensivas en las zonas de la planta no infectadas, haciendo a la planta más resistente. Esta resistencia distal recibe el nombre de resistencia sistémica adquirida (SAR; Ryals et al., 1996).

Se sabe que, además de la acumulación de fitoalexinas, la respuesta defensiva incluye, entre otras reacciones, la síntesis de proteínas y compuestos fenólicos que refuerzan la pared celular, así como la producción de un conjunto de proteínas denominadas PRs (del inglés "Pathogenesis - Related"). Conviene resaltar que, aunque éstas son proteínas de defensa, tienen una función distinta a la de las proteínas $R$ : las proteínas $R$ de resistencia son elementos que actúan en la percepción del patógeno y génesis de la señal, que mediante una serie de iones, moléculas y dispositivos celulares, es convertida y transmitida (transducción) en una orden de activación de la respuesta. Las proteínas PRs son ellas mismas armas de ataque al patógeno y, por lo tanto, componentes de la propia respuesta (Conejero, 1996).

Por último, se sabe que, la generación de especies reactivas de oxígeno (Reactive Oxygen Species, ROS, ión superóxido $\mathrm{O}_{2}^{-}$y peróxido de dihidrógeno $\mathrm{H}_{2} \mathrm{O}_{2}$, fundamentalmente) contribuyen de forma significativa a los diferentes mecanismos de defensa de la planta frente a patógenos (Low y Merida, 1996). Además de su función señalizadora, las especies de oxígeno activo son tóxicas per se para el patógeno. También se sabe que el $\mathrm{H}_{2} \mathrm{O}_{2}$ liberada durante el proceso de infección puede contribuir al refuerzo de las barreras físicas que se oponen a la entrada y penetración del patógeno en la planta. En este sentido, Harbin y Obst (1973) y Elstner y Heupel (1976), vieron que el $\mathrm{H}_{2} \mathrm{O}_{2}$ era necesaria para el proceso de lignificación. De hecho, se ha detectado biosíntesis de $\mathrm{H}_{2} \mathrm{O}_{2}$ en tejidos vegetales en los que hay una deposición activa de lignina (Olson y Varner, 1996).

La acumulación de especies reactivas de oxígeno puede estar relacionada con la inducción de la respuesta hipersensible. Baker et al. (1993) han demostrado que existe una estrecha relación entre la respuesta hipersensible, activada como consecuencia de 
una interacción incompatible entre planta y patógeno, y la puesta en marcha de la respuesta oxidativa.

En la figura 2 se muestra un esquema de los diferentes mecanismos de defensa de las plantas frente a patógenos. Tal y como se observa en el esquema, la respuesta defensiva de las plantas se caracteriza por ser de naturaleza multicomponente, incluyendo un sistema de señalización de dicha respuesta, producción de enzimas implicadas en la biosíntesis de compuestos antimicrobianos (lignina, fitoalexinas, etc.) y acumulación de proteínas que frenan la expansión del patógeno (glucanasas, quitinasas, etc.).

A continuación se explican de forma más detallada los diferentes componentes de la interacción planta-patógeno que integran la respuesta defensiva de la planta, haciendo especial hincapié en el papel de los productos naturales en la defensa de las plantas frente a patógenos.

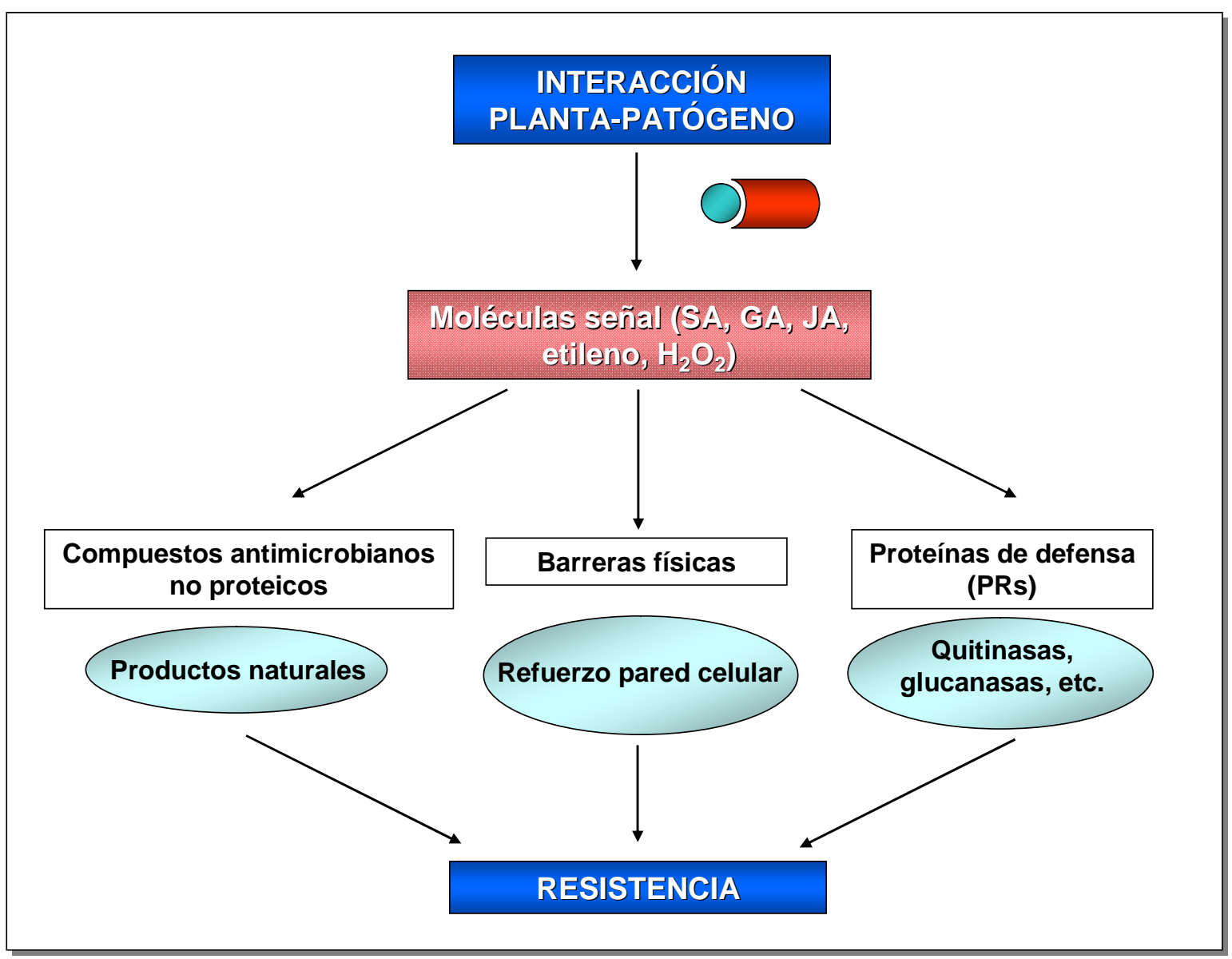

Figura 2. Naturaleza multicomponente de la respuesta defensiva. SA, ácido salicílico; GA, ácido gentísico; JA, ácido jasmónico. Adaptado de Conejero (1997). 


\section{I.1.2.- La percepción del patógeno.}

\section{I.1.2.1.- El reconocimiento inespecífico: elicitores o PAMPs.}

Los patógenos vegetales utilizan diversas estrategias de ataque que tienen como finalidad penetrar en la planta y colonizarla: las bacterias fitopatógenas entran a través de los estomas, de poros acuosos o de heridas y proliferan en los espacios intercelulares (apoplasto), los nemátodos y áfidos se alimentan insertando su estilete directamente en una célula vegetal, los hongos pueden entrar directamente a través de las células epidérmicas, o extender sus hifas en la superficie de las células. Sin embargo, todos ellos tienen algo en común: liberan factores de virulencia en las células vegetales, con el fin de crear un entorno favorable para su proliferación en la planta (Jones y Dangl, 2006).

Cuando un patógeno entra en contacto con una planta e intenta infectarla, se pone en marcha un sistema de comunicación molecular entre ambos, que desencadena la inducción de mecanismos de defensa en la planta (Desender et al., 2007). Los elicitores o PAMPs (Pathogen-Associated Molecular Patterns), son el conjunto de moléculas producidas por el patógeno o por el mismo huésped en una fase inicial del encuentro entre ambos, capaces de inducir la respuesta defensiva en la planta (Jones y Dangl, 2006; Hückelhoven, 2007; Desender et al., 2007). Los PAMPs son reconocidos en las células vegetales (figura 3) por receptores transmembrana no específicos (PRRs, pattern recognition receptors). Dicho reconocimiento desencadena una serie de cambios en las células de la planta tales como variaciones en el potencial de membrana, producción de ROS, peroxidación de lípidos y fosforilación de proteínas, que alteran la fisiología celular y generan mensajeros químicos implicados en la activación de la resistencia local o sistémica (Dixon y Lamb, 1990; Desender et al., 2007). Los mecanismos de defensa de la planta activados por los elicitores o PAMPs (PTI, PAMPstriggered immunity; Jones y Dangl, 2007) incluyen entre otros el refuerzo de la pared celular mediante deposiciones de callosa y lignina (Hückelhoven, 2007), la producción de proteínas de defensa PR (quitinasas y glucanasas), la expresión de genes que codifican proteínas que participan en el establecimiento de barreras físicas que frenan la expansión del patógeno y la inducción de enzimas que participan en la biosíntesis de metabolitos secundarios antimicrobianos (Broekaert et al., 2006). 
El ejemplo más característico de un PAMP viene representado por el elicitor bacteriano 'flagelina', capaz de activar la respuesta defensiva en diversas plantas (Gómez y Boller, 2002). La movilidad de las bacterias mediante flagelos es importante para su fitopatogenicidad (Zipfel y Felix, 2005). La flagelina es un elicitor proteico, proveniente de los flagelos bacterianos, que contiene un dominio peptídico de 22 aminoácidos conservado (flg22) capaz de inducir gran cantidad de respuestas celulares (Felix et al., 1999), incluyendo la rápida inducción transcripcional (en menos de 1 hora) de al menos 1100 genes en Arabidopsis thaliana (Zipfel et al., 2004).

\section{I.1.2.2.- El reconocimiento específico: la interacción gen a gen.}

En ocasiones, los patógenos pueden superar la resistencia de la planta activada como consecuencia del reconocimiento de los PAMPs. Dichos patógenos son capaces de sintetizar 'efectores', que no son más que factores de avirulencia (Avr) (Jones y Dangl, 2006). Los efectores pueden ser reconocidos de forma específica por proteínas NB-LRR, que son producto de los genes de resistencia $R$ de la planta. Reciben ese nombre ya que tienen la capacidad de unirse a nucleótidos (NB, nucleotide binding) y porque poseen dominios repetidos ricos en el aminoácido leucina (LRR, leucine rich repeat). En el caso de que ninguno de estos efectores encuentre en la planta el gen de resistencia $R$ correspondiente, la infección se extenderá a toda la planta, lo que se conoce como interacción compatible. $\mathrm{Si}$, por el contrario, un determinado efector patogénico es reconocido de forma específica por una proteína NB-LRR, estaremos frente a una interacción de tipo incompatible, que normalmente va asociada a la muerte celular programada o repuesta hipersensible (HR) (figura 3). 


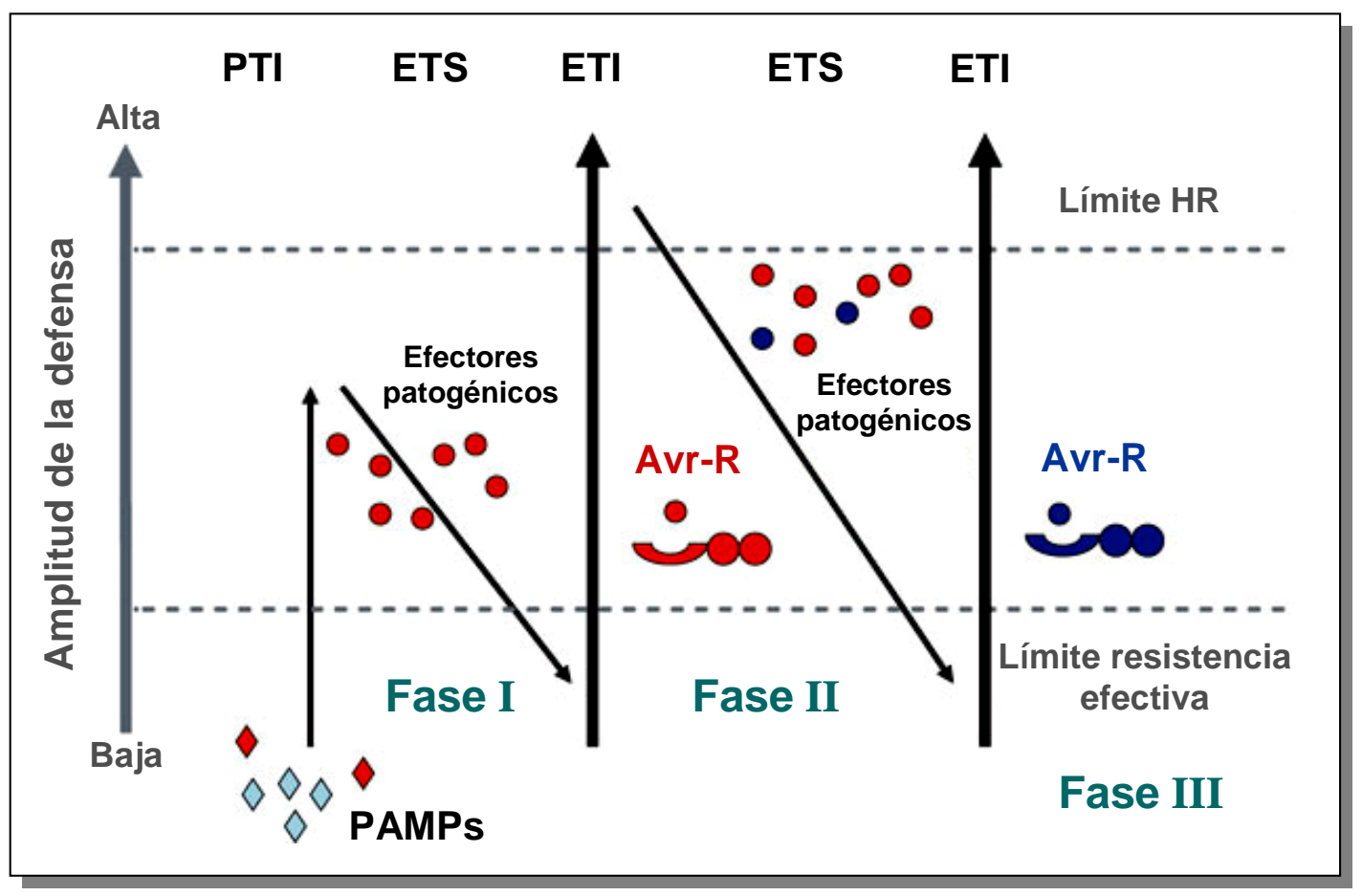

Figura 3. Modelo ilustrativo del sistema inmunológico de las plantas. En la fase I, la planta detecta los PAMPs (Pathogen-Associated Molecular Patherns) mediante receptores transmembrana no específicos (PRRs, pattern recogniction receptors) estableciéndose mecanismos de defensa en la planta activados por los PAMPs (PAMPs-triggered immunity o PTI). En la fase II, ciertos efectores patogénicos pueden interferir la PTI estableciéndose un susceptibilidad ligada dichos efectores (Effector-triggered susceptibility o ETS). El la fase III, un determinado efector patogénico o factor de avirulencia es reconocido de forma específica por un gen $\mathrm{R}$ de la planta estableciéndose un inmunidad ligada al efector (Effector-triggered immunity o ETI) y se produciéndose la repuesta hipersensible (HR). Adaptado de Jones y Dangl (2006).

\section{I.1.3.- La respuesta de la planta.}

\section{I.1.3.1.- Las respuestas defensivas locales.}

Uno de los eventos más rápidos que acontecen en la célula vegetal tras la percepción del patógeno es un cambio en el potencial y la permeabilidad de la membrana plasmática. Los canales iónicos como la bomba $\mathrm{H}^{+}$-ATPasa, se ven alterados. Se produce una modificación del flujo de iones que conlleva una acumulación de $\mathrm{Ca}^{2+}$ en el citoplasma y una salida extracelular de $\mathrm{Cl}^{-}$y K $\mathrm{K}^{+}$(Trewavas y Malhó, 1998; White y Broadley, 2003; Zhao et al., 2005). El calcio parece jugar un papel importante en el establecimiento de las barreras defensivas, ya que es un segundo mensajero implicado en una gran variabilidad de procesos celulares y cambios fisiológicos (Trewavas y Malhó, 1998). Por una parte podría estar implicado en la síntesis y acumulación de metabolitos secundarios (Smith, 1994), además de en la producción de 
ROS y $\mathrm{H}_{2} \mathrm{O}_{2}$ (Price et al., 1994, Lecorieux et al., 2002). Por otra parte, podría estar activando de forma diferencial factores de transcripción que regulen directamente la expresión de genes de defensa en la planta (Dolmetsch et al., 1997, Yang y Poovaiah, 2002).

Otro de los primeros eventos que acontecen en una célula vegetal tras la percepción del patógeno, es la acidificación del citoplasma y la consiguiente alcalinización del medio (apoplasto). Este fenómeno ha sido utilizado para localizar los sitios de unión del elicitor patogénico en la célula vegetal. Se cree que la alcalinización del apoplasto y la subsiguiente acidificación del citoplasma, es debida a una despolarización de la membrana plasmática inducida por los elicitores patogénicos, con la consiguiente entrada de calcio en el citoplasma y salida de cloro al apoplasto (Boller, 1995; Zhao et al. 2005). La acidificación del citoplasma es fundamental en la transducción de la señal de la respuesta defensiva, ya que constituye un paso previo a la generación de ROS y a la biosíntesis de metabolitos secundarios (Shakano, 2001; Zhao et al., 2005). Por ejemplo, se ha comprobado que cuando en un cultivo celular de tabaco se acidifica artificialmente el citoplasma de las células, se produce un incremento en la transcripción de los genes que codifican la fenilalanina amonio liasa (PAL) y la 3hidroxi-3-metilglutaril-CoA reductasa (HMGR), dos enzimas implicados en las rutas biosintéticas de los fenilpropanoides y de los terpenos respectivamente (Lapous et al., 1998). Además, Armero y Tena (2001) demostraron que la inhibición de la bomba $\mathrm{H}^{+}$ATPasa de la membrana plasmática y, más concretamente, el bombeo de protones al apoplasto, podría activar una ruta de señalización para la secreción de fitoalexinas e isoflavonas al medio (apoplasto). Estos resultados sugieren que la acidificación del citoplasma como consecuencia de la percepción del patógeno por parte de la planta, no es una mera respuesta local frente a la infección, sino también un proceso regulatorio que podría mediar otras respuestas celulares (Zhao et al. 2005).

Las explosión oxidativa o generación de especies reactivas de oxígeno (ROS), tales como el anión superóxido $\left(\mathrm{O}_{2}^{-}\right)$o el peróxido de hidrógeno $\left(\mathrm{H}_{2} \mathrm{O}_{2}\right)$, produce intermediarios tóxicos que provienen de la reducción del oxígeno molecular. En las plantas se conocen diferentes fuentes de generación de ROS, como por ejemplo el complejo NADPH oxidasa, la peroxidasa apoplástica, y otras oxidasas de la mitocondria, cloroplasto y peroxisomas (Zhao et al., 2005). En la mayoría de las 
especies vegetales es la activación del complejo NADPH oxidasa la fuente principal generación de ROS, aunque en algunas plantas también intervienen las peroxidasas del apoplasto (Bolwell y Wojtaszek, 1997). Las ROS, aparte de resultar directamente tóxicas para el patógeno, están implicadas en numerosos procesos que acompañan a la respuesta defensiva. $\mathrm{El} \mathrm{H}_{2} \mathrm{O}_{2}$ interviene en el reforzamiento de las paredes celulares, favoreciendo el entrecruzamiento de sus componentes o incrementando la síntesis y secreción de polímeros de lignina, por medio de un aumento en la actividad peroxidasa (Kawano, 2003). Además, es una señal intermediaria en la inducción de la explosión oxidativa. Con la explosión oxidativa se activan algunos genes de defensa, y la acción conjunta y coordinada de ROS, del óxido nítrico (NO) y del ácido salicílico (SA), activa el proceso de muerte celular programada en la respuesta hipersensible (Delledonne et al., 1994; Romero-Puertas et al., 2004). Por último, la generación de ROS también parece estar implicada en la acumulación de metabolitos secundarios. En algunas plantas, el $\mathrm{H}_{2} \mathrm{O}_{2}$ media la acumulación de compuestos defensivos, tales como la gliceolina en soja (Degousee et al., 1994; Guo et al., 1998), p-cumaroiloctopamina en tubérculos de patata (Matsuda et al., 2001) o alcaloides indólicos en Catharanthus roseus (Zhao et al., 2001), entre otros. En otras plantas es el anión superóxido el que interviene en la producción de metabolitos secundarios tales como, la acumulación de fitoalexinas (furanocumarinas) en cultivos celulares de perejil (Jabs et al., 1997) o capsidiol en tabaco (Perrone et al., 2003). Hasta el momento, no se conoce de forma precisa la forma en la que las especies reactivas de oxígeno podrían regular la producción de metabolitos secundarios. Sin embargo, lo que sí que está claro es que la explosión oxidativa activa la expresión de una gran cantidad de genes de defensa y genes implicados en las rutas biosintéticas de metabolitos, tales como sesquiterpeno ciclasas o la fenilalanina amonio liasa (PAL) (Zhao et al., 2005).

La explosión oxidativa puede acontecer en dos fases, dependiendo del tipo de interacción patogénica que se produzca. De este modo, tanto en la interacción compatible como en la incompatible, se produce una primera acumulación de ROS a pequeña escala que ocurre a los 10-30 min de la interacción. Esta primera acumulación de especies reactivas de oxígeno no afecta a la viabilidad de la célula. La segunda explosión oxidativa, a mayor escala y más prolongada, sólo se da en las interacciones incompatibles y tiene lugar pocas horas después de la infección (1-3 horas). Esta 
segunda fase es crítica para el establecimiento de la resistencia y la activación de la HR (Levine et al., 1994; Lamb y Dixon, 1997; Feys y Parker., 2000).

La HR es el primer síntoma visible que testifica que la planta ha respondido frente al ataque patogénico (Desender et al., 2007). Como ya se ha comentado en apartados anteriores (ver página 6), la reacción hipersensible (HR) se produce tras el reconocimiento de los productos de los genes $A v r$ y $R$ y consiste en una muerte celular localizada en el sitio de infección, que acontece de forma macroscópica a las 12-48 horas después de la infección (Penell y Lamb, 1997). Normalmente va asociada a interacciones incompatibles aunque, en ocasiones, en ciertas interacciones compatibles las características microscópicas del tejido necrótico son idénticas a la HR (Vleeshouwers et al., 2000). Por otra parte, se ha observado que la inoculación con un patógeno activa también la muerte celular en hojas distales no inoculadas. Este efecto se conoce como microHR (Álvarez et al., 1998), que no puede apreciarse a simple vista. En ausencia de la activación de la HR, gran parte de la respuesta defensiva no tiene lugar y por lo tanto, la infección se extiende a toda la planta, desencadenando el desarrollo de la enfermedad (Lorrain et al., 2003).

También como respuesta defensiva local, la planta induce la síntesis de fitoalexinas y metabolitos secundarios, tal y como se ha venido diciendo en párrafos anteriores, y la expresión de proteínas relacionadas con la patogénesis (Pathogenesis Related Proteins, PRs), que serán tratadas en el siguiente apartado. Por su parte, la implicación de las fitoalexinas y, en general, del metabolismo secundario, en el sistema defensivo de la planta, serán tratados en posteriores apartados.

\section{I.1.3.2.- Las respuestas defensivas sistémicas.}

Durante la década de los años 60 Ross (1961) observó que plantas de tabaco que habían sido infectadas con TMV (tobacco mosaic virus) mostraban resistencia frente a una segunda infección en tejidos distales. A este tipo de resistencia se le acuñó con el nombre de resistencia sistémica adquirida (SAR), y se caracteriza por activarse después de la infección por parte de un patógeno necrosante o tras la aparición de HR. En este tipo de respuesta la resistencia que adquiere la planta es duradera (a veces para el resto de la vida de la planta) y contra un amplio espectro de patógenos tales como virus, 
bacterias, hongos y oomicetos (Ryals et al., 1996; Sticher et al., 1997; Durrant y Dong, 2004).

La respuesta SAR va acompañada por el incremento en la expresión de un gran número de genes de proteínas PR (pathogeneis related), tanto en tejidos locales como distales. Las primeras PRs descritas se detectaron en plantas de tabaco sometidas a una infección con TMV de tipo incompatible (HR) (Gianinazzi et al., 1970; van Loon y van Kammen, 1970). En la actualidad ya han sido caracterizadas numerosas PRs en diferentes especies vegetales y se clasifican en 17 familias. La mayoría de las PRs se inducen bajo la acción de moléculas señalizadoras de la respuesta defensiva tales como el ácido salicílico (Shah, 2003), el ácido gentísico (Bellés et al., 1999), el ácido jasmónico (Browse, 2005) o el etileno (Broekaert et al., 2006). Además gran parte de las PRs descritas poseen actividad antimicrobiana in vitro (García-Breijo et al., 1990; Rodrigo et al., 1993; Collinge et al., 1993; Domingo et al., 1994), y algunas de ellas podrían estar implicadas en la señalización de la respuesta defensiva (van Loon et al., 2006b).

El hecho de que la acumulación de PRs esté asociada a la expresión de los genes relacionados con SAR y al establecimiento de la resistencia sistémica adquirida, hace pensar que dichas proteínas defensivas podrían ser los agentes responsables de la resistencia inducida frente a un gran número de patógenos en las subsiguientes infecciones. Sin embargo esta hipótesis no ha cobrado fuerza debido a que se ha observado que las plantas transgénicas que sobreexpresan una o más PRs, no muestran mayor resistencia frente a infecciones víricas, contrastando con los resultados obtenidos en plantas transgénicas que expresan SAR de forma constitutiva, que si muestran mayor resistencia frente a cualquier tipo de infección (van Loon et al., 2006b). Además, se ha comprobado que ciertos patógenos de naturaleza fúngica tales como Botrytis cinerea en tabaco o Alternaria brassicicola en Arabidopsis, son insensibles al establecimiento de la SAR. Dichos patógenos son sensibles a un mecanismo de resistencia inducida diferente a SAR, que es independiente a la inducción de PRs (Thomma et al., 2001; Ton et al., 2002). Este tipo de resistencia se conoce con el nombre de resistencia sistémica inducida (ISR), ya que es activada por cepas bacterianas no patogénicas que colonizan la raíz de ciertas especies vegetales (van Loon y Pieterse, 2002). La ISR es activa frente a un amplio espectro hongos y bacterias patogénicos, pero, a diferencia de la SAR, no es 
activa contra virus. El establecimiento de la SAR requiere la previa acumulación de ácido salicílico (local y sistémica), mientras que la ISR está regulada por etileno y ácido jasmónico (Grant y Lamb, 2006).

\section{I.1.4.- Las rutas de señalización de la respuesta defensiva en la planta.}

\section{I.1.4.1.- La ruta del ácido salicílico (SA).}

El ácido salicílico es la primera molécula a la que se atribuyó un papel importante en la intermediación de la transducción de la señal patogénica primaria, hasta la respuesta final. Es un compuesto fenólico natural presente en un gran número de plantas. Se sabe que está implicado en gran cantidad de procesos fisiológicos y bioquímicos; sin embargo, la función fisiológica mejor caracterizada del ácido salicílico (SA) es la de la activación de programas de defensa inducibles, confiriendo a la planta resistencia frente a patógenos (Álvarez, 2000). Efectivamente, el SA parece desempeñar un papel fundamental en HR y SAR. Además el SA es también necesario para el desarrollo de los síntomas de la enfermedad (O’Donnell et al., 2003). El incremento en los niveles endógenos de SA y de sus conjugados en plantas infectadas, coincide con la activación de genes que codifican para proteínas PR y con el establecimiento de la resistencia en la planta (Shah, 2003).

Numerosos estudios han demostrado la implicación del SA en el desarrollo de la resistencia local y sistémica. En este sentido ha sido clave la utilización de plantas transgénicas que no pueden acumular ácido salicílico ya que, llevan incorporado el gen $N a h G$, que codifica el enzima salicilato hidroxilasa, y que transforma el ácido salicílico en catecol. Estas plantas son incapaces de activar la SAR y, además, son más susceptibles al desarrollo de enfermedades que sus parentales (Gaffney et al., 1993; Delaney et al., 1994; Mur et al., 1997). Por otra parte, la aplicación exógena de SA activa la expresión de genes $P R$ y hace a la planta más resistente a cualquier ataque patogénico (Shah, 2003). 


\section{Biosíntesis del SA.}

Hasta hace unos años, estaba ampliamente admitido que el SA era sintetizado en la planta a partir de la fenilalanina, a través de la ruta de los fenilpropanoides (Verbene, et al., 1999). Sin embargo, actualmente se admite que la ruta biosintética del isocorismato es la principal fuente de SA durante la infección patogénica y el establecimiento de la SAR (Willdermuth et al., 2001). Los enzimas isocorismato sintasa (ICS) e isocorismato piruvato liasa (IPL) catalizan la biosíntesis en dos pasos del SA a partir de isocorismato (figura 4, Serino et al., 1995). Dicha biosíntesis tiene lugar en el cloroplasto. Algunos autores han demostrado que plantas que sobreexpresan estos enzimas experimentan un aumento en los niveles de acumulación de SA (Mauch et al., 1995; Verberne et al., 2000). La expresión del gen de Arabidopsis SID2 (Salicylic-AcidInduction Defitient2) que codifica una ICS localizada en el cloroplasto, es activada en tejidos infectados o que han establecido la SAR. Las plantas de Arabidopsis mutadas en sid2 o en el alelo eds 16 (enhnaced disuade susceptibility16), son defectivas en la síntesis de SA y en la activación de la SAR, exhibiendo una mayor susceptibilidad frente al ataque patogénico (Nawrath y Métraux, 1999; Willdermuth et al., 2001). La aplicación exógena de SA complementa el fenotipo observado en el mutante sid2, confirmándose así la implicación de SID2 en la biosíntesis de SA (Shah, 2003).

El transporte de SA al citoplasma podría llevarlo a cabo la proteína de membrana EDS5/SID1 que muestra identidad con proteínas de extrusión de drogas y toxinas (MATE) (Nawrath et al., 2002). La activación de la síntesis de SA por el ataque patogénico o por la exposición a luz UV se encuentra bloqueada en los mutantes eds5/sid1 (Nawrath et al., 2002) y eds1/pad4 (Jirage et al., 1999; Feys et al., 2001). Además, los mutantes eds1/pad4 bloquean la expresión de EDS5 activada por patógenos, sugiriendo que EDS1 y PAD4 actúan aguas arriba de EDS5 en la regulación de la síntesis de SA (Nawrath et al., 2002). 


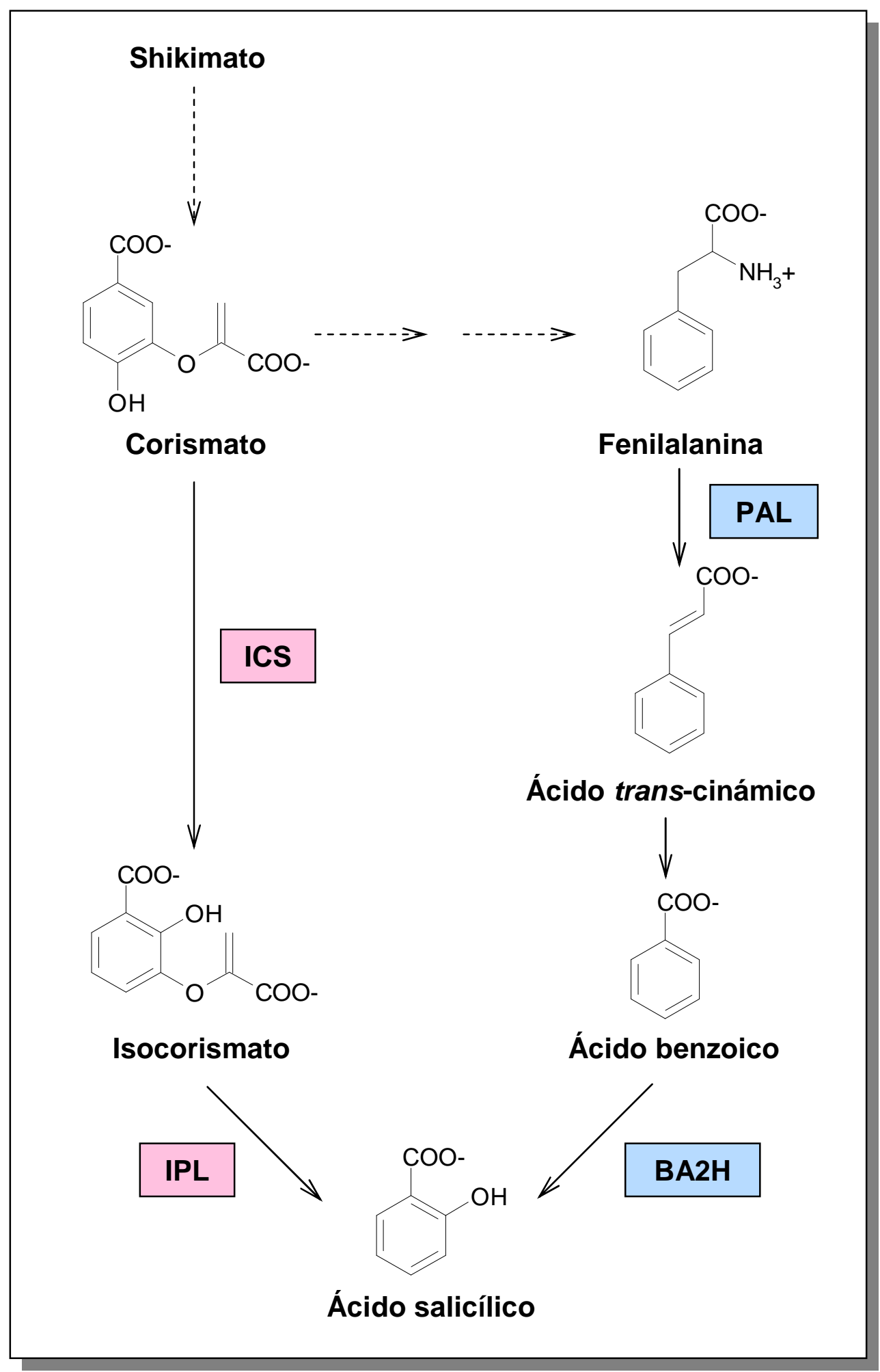

Figura 4. Rutas biosintéticas del ácido salicílico (SA). ICS, isocorismato sintasa; IPL, isocorismato piruvato liasa; PAL, fenilalanina amonio liasa; BA2H, ácido benzoico-2hidroxilasa. Adaptado de Shah (2003). 


\section{Mecanismo de señalización del SA.}

Con el fin de identificar los componentes implicados en la transducción de la señal mediada por SA, se aislaron y se caracterizaron un gran número de mutantes de múltiples alelos de un mismo gen: NPR1 (Non-expressor of PR1; Cao et al., 1994; Delaney et al., 1995, Glazebrook et al., 1996; Shah et al., 1997; Durrant y Dong, 2004). Los mutantes nprl de Arabidopsis eran más susceptibles a patógenos virulentos y algunos no eran capaces de activar la expresión de genes de defensa $P R$ en respuesta a SAR (Cao et al., 1994; Delaney et al., 1995, Glazebrook et al., 1996; Shah et al., 1997). NPR1 es un regulador positivo central de la respuesta SAR y funciona aguas abajo del SA (Grant y Lamb, 2006).

La acumulación de SA parece regular la actividad de NPR1 en dos fases: en primer lugar, activa la expresión de NPR1, y en segundo lugar, el SA induce un cambio en el potencial de membrana y esto estimula la traslocación de NPR1 al núcleo donde interacciona con factores de transcripción TGA (Kinkema et al., 2000; Mou et al., 2003; Despres et al., 2000). Los TGAs se unen específicamente a secuencias de ADN activadoras (as-1) presentes en los promotores de algunos genes de respuesta a SA, como PR1 (Despres et al., 2000; Zhou et al., 2000). Los subsiguientes cambios transcripcionales que acontecen, contribuyen al establecimiento de la SAR (Grant y Lamb, 2006). La función de NPR1 parece estar conservada entre especies monocotiledóneas y dicotiledóneas, ya que se ha demostrado que la sobreexpresión de NPRl en arroz (o de su ortólogo NH1) confiere una mayor resistencia frente a la bacteria Xanthomonas oryzae pv. oryzae (Chern et al., 2005).

NPR1 es necesario no sólo para la respuesta SAR sino también para la respuesta ISR (Resistencia Sistémica Inducida). Como se ha comentado en apartados anteriores, dicha respuesta está asociada a rizobacterias y confiere resistencia frente a bacterias y hongos en la parte aérea de la planta (Shah y Klessig, 1999; Schenk et al., 2000). Además NPR1 está también implicado en la señalización cruzada (cross-talk) entre la ruta del SA y la del ácido jasmónico (JA) y la del etileno, confiriendo resistencia frente a insectos y patógenos necrotrofos (Spoel et al., 2003). 
En los últimos años se han encontrado mutantes, supresores de nprl, que ponen de manifiesto la posibilidad de expresión de genes PR y de resistencia a patógenos independiente de nprl. Tal es el caso de los mutantes snil (Li et al., 1999), scnl (Li et al., 2001) y ssi2 (Shah et al., 2001). Otro posible regulador de la respuesta SAR, independiente de NPR1, incluye DTH9. El mutante dth9 muestra una mayor susceptibilidad frente a patógenos virulentos, acumula elevados niveles de SA, y no es capaz de establecer la SAR en respuesta a una infección patogénica o a un tratamiento con SA (Mayda et al., 2000). Estos fenotipos son similares a los encontrados en el mutante $n p r l$, sin embargo, dth9 difiere de nprl en que en él, la expresión de PRl y $P R 2$ en respuesta a una infección o a un tratamiento con SA, no está alterada. Esto demuestra que DTH9 es necesario para la SAR, en una ruta paralela a NPR1, pero no para la expresión de los genes característicos de SAR (Mayda et al., 2000). Además, dth9 es insensible a un tratamiento con auxinas, indicando que la señalización por auxinas podría jugar un papel importante en la señalización de la respuesta defensiva en la planta (Durrant y Dong, 2004).

\section{I.1.4.2.- La ruta del ácido jasmónico (JA).}

El ácido jasmónico (JA) es una molécula de naturaleza lipídica (oxilipina) que regula una gran variedad de procesos relacionados con el desarrollo en la planta (elongación de raíces, dehiscencia de anteras, maduración de semillas, etc.). También juega un papel fundamental en la señalización de la respuesta a herida o ataque por insectos, así como en la resistencia frente a patógenos necrotrofos.

\section{Biosíntesis del JA.}

El JA es uno de los productos finales de la ruta de los octadecenoides, que comienza con la liberación de ácido linolénico de las membranas plasmáticas (Vick y Zimmerman, 1983; Narvaez-Vazquez et al., 1999). Hay evidencias que indican que la biosíntesis del JA parece completarse en dos compartimentos celulares diferentes (figura 5; Strassner et al., 2002). En el cloroplasto, el ácido linolénico es transformado en ácido 12-oxo-fitodienoico (OPDA). Posteriormente, en los peroxisomas, el ácido 12oxo-fitodienoico sufre tres etapas de $\beta$-oxidación, que finalmente darán lugar al ácido jasmónico (Creelman y Mullet, 1997; Schaller, 2001; Browse, 2005). 
Además, se ha encontrado un gran número de derivados del JA en plantas que podrían desempeñar interesantes funciones biológicas (Sembdner y Parthier, 1993). En efecto, existen evidencias de que el metil jasmonato (MeJA) (Seo et al., 2001), el conjugado del JA con isoleucina (Staswick y Tiryaki, 2004), y el precursor de JA, OPDA (Stintzi et al., 2001), son biológicamente activos. También son activos los productos derivados de los ácidos grasos denominados oxilipinas u octadecenoides (Weber et al., 1997).

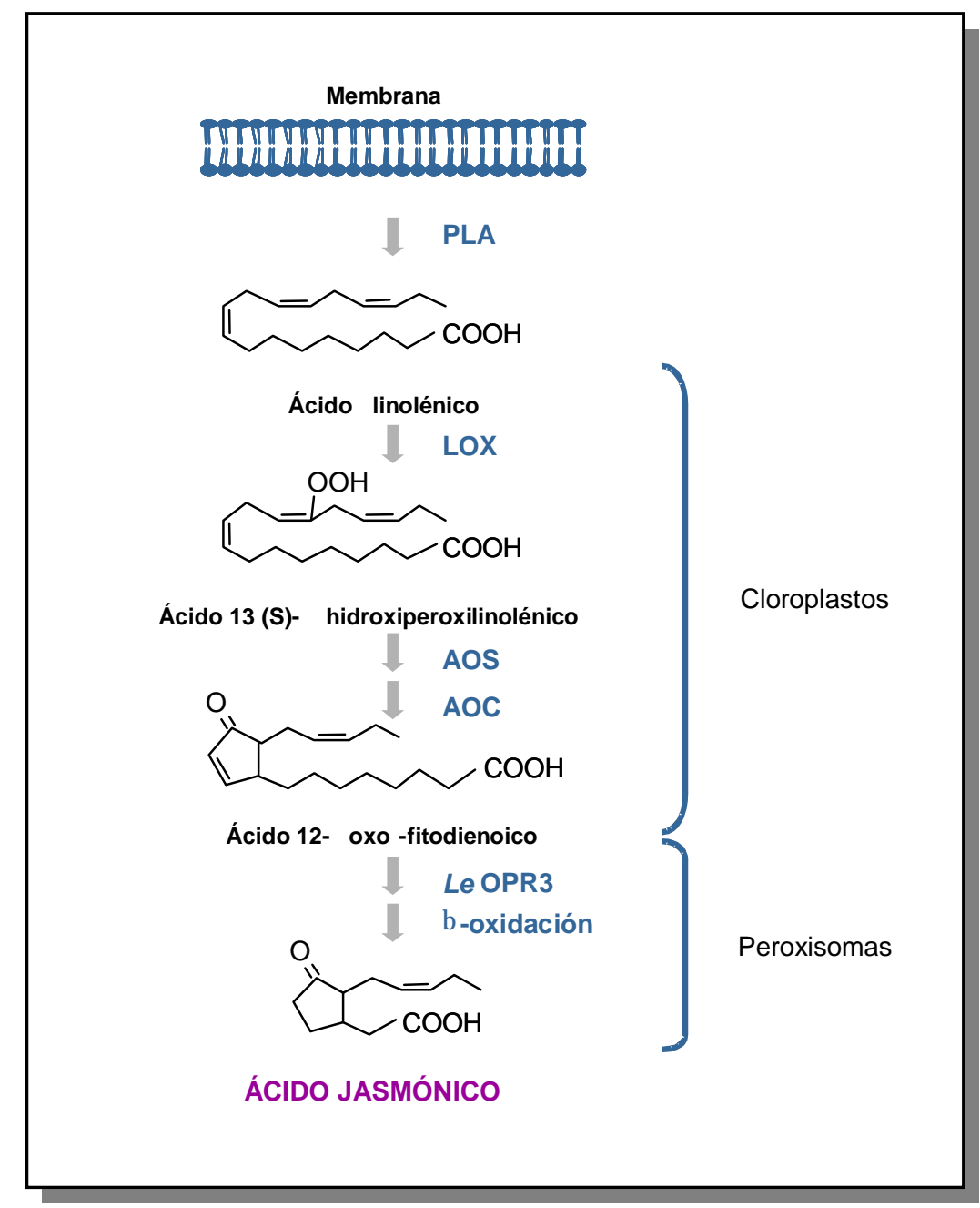

Figura 5. Ruta de biosíntesis del ácido jasmónico. La ruta tiene lugar en dos compartimentos diferentes. PLA: fosfolipasa $\mathrm{A}_{2}$; LOX: lipoxigenasa; AOS: óxido aleno sintasa; AOC: óxido aleno ciclasa; LeOPR3: isoforma 3 de la 12-oxofitodienoato reductasa de Lycopersicon esculentum. Adaptado de Schaller (2001). 
Mecanismo de señalización del JA.

Una de las rutas de señalización por JA más estudiadas, es la respuesta a herida, que inicialmente se estudió en tomate. Después de producirse una herida en la planta, se activa localmente la biosíntesis de prosistemina que a su vez estimula la síntesis de un péptido de 18 aminoácidos, la sistemina. La acumulación de sistemina activa la síntesis de enzimas implicados en la ruta biosintética del JA, tales como la AOC (Allene oxide cyclase), produciéndose un aumento local en los niveles de JA (Wasternack, 2006). El JA actúa como una señal sistémica que activa la expresión de genes que codifican inhibidores de proteasas (PINs), así como la acumulación de compuestos en las hojas, teniendo ambos efectos negativos en el desarrollo de herbívoros. Como consecuencia, la planta queda inmunizada frente a subsiguientes ataques de insectos.

La respuesta a herida mediada por JA desencadena una respuesta defensiva por parte de la planta que puede ser indirecta (emisiones de compuestos volátiles) y directa (acumulación de proteínas de defensa y compuestos de bajo peso molecular) (Halitschke y Baldwin, 2004; Howe, 2004; Pieterse et al., 2006). De entre las proteínas de defensa que se acumulan en tomate se han encontrado PINs que degradan enzimas digestivos en el tracto intestinal de insectos. Además de los PINs, en tomate se inducen por ataque de insectos otras proteínas tales como aminopeptidasas de leucina, deaminasas de treonina (TD) y arginasas (Walling, 2000; Chen et al., 2004), que poseen también dicha actividad proteolítica.

Los mutantes en la ruta de biosíntesis y de señalización del JA, han sido una herramienta muy valiosa para determinar las propiedades señalizadotas del JA y de sus compuestos relacionados, en Arabidopsis thaliana (Turner et al., 2002; Lorenzo y Solano, 2005; Delker et al., 2006; Wasternack, 2006). Los análisis realizados con el mutante opr3, que no acumula JA pero si su precursor, el OPDA, revelaron que la expresión de ciertos genes de respuesta a herida dependía exclusivamente de OPDA (Stintzi et al., 2001). Entre los estudios con mutantes de Arabidopsis afectados en la biosíntesis, en la percepción o en el modo de acción del JA, cabría destacar el hallazgo de coil (Feys et al., 1994) y jarl (Staswick et al., 2002). COIl codifica una proteína cuya secuencia parece indicar que podría funcionar promoviendo la degradación de un regulador negativo de la transducción de la señal del JA (Xie et al., 1998; Xu et al., 
2002; Feng et al., 2003). El mutante coil es hipersusceptible a algunas bacterias necrotrofas (Devoto y Turner, 2005), sin embargo, confiere resistencia a distintas cepas de la bacteria biotrofa Pseudomonas syringae (Kloek et al., 2001; Ellis et al., 2002). En la defensa frente a dicha bacteria están implicados diferentes componentes de la ruta de señalización dependiente de SA. Estos datos implican a COI1 como un posible factor de conexión entre las rutas de señalización del JA y del SA. El otro mutante, insensible a JA, jarl, permite un aumento de los niveles de crecimiento de $P$. syringae pv. tomato (Pieterse et al., 1998). Estudios funcionales de JAR1 mostraron que esta proteína está relacionada con enzimas formadores de adenilato, en soja (Staswick et al., 2002), implicando el proceso de adenilación, en la respuesta dependiente de JA. Otros mutantes de interés son los tipo cet (Hilpert et al., 2001), que tienen incrementados los niveles de JA, pudiendo actuar de reguladores negativos en la señalización por JA. También se han descrito algunos genes que se inducen en respuesta al JA y que codifican proteínas relacionadas con la patogénesis. Tal es el caso de la defensina PDF1.2, comúnmente utilizada como marcador de las respuestas defensivas dependientes de JA (Reymond y Farmer, 1998; Devoto y Turner, 2003). Al igual que ocurre con la señalización dependiente de SA, la señalización con JA tiene efectos sistémicos. Así, al inocular unas pocas hojas basales con Alternaria brassicicola, la planta entera es capaz de de expresar PDF1.2 (Penninckx et al., 1996).

\section{I.1.4.3.- La ruta del etileno (ET).}

El etileno es una fitohormona clave en la señalización de procesos vitales para el desarrollo de las plantas y en la activación de respuestas defensivas frente a las agresiones del medio. En muchos casos, cuando un patógeno entra en contacto con una planta, se produce un importante aumento en los niveles de acumulación de etileno (Boller, 1991; Cohn y Martin, 2005; Penninckx et al., 1998; Ross y Williamson, 1951; van Loon, 1977). La activación de la biosíntesis de etileno requiere el reconocimiento previo de elicitores moleculares derivados del patógeno o bien el reconocimiento de factores de avirulencia por parte de receptores específicos en la planta (Broekaert et al., 2006; Hammond-Kosack y Parker, 2003; Nimchuk et al., 2003; Nurnberger et al., 2004). 


\section{Biosíntesis del ET.}

El etileno se sintetiza a partir del aminoácido metionina, que es convertido en $S$ adenosil-metionina ( $S$-AdoMet) en una reacción catalizada por el enzima $S$-AdoMet sintasa (ADS) (figura 6). La AdoMet pasa a ácido 1-aminociclopropano 1-carboxílico (ACC), el precursor del etileno, en una reacción catalizada por el enzima ACC sintasa (ACS). El ACC es finalmente oxidado a etileno a través del enzima ACC oxidasa (ACO). El paso de AdoMet a ACC es el que limita la velocidad del proceso de síntesis del etileno, estando la actividad del enzima ACC sintasa estrechamente regulada (Chae y Kieber, 2005; Broekaert et al., 2006). Además, la ACS se activa en la planta como respuesta a la infección del viroide de la exocortis de los cítricos (CEVd), causando también un aumento en el nivel de etileno (Bellés y Conejero, 1989; Bellés et al., 1989). Una vez producido, el etileno se difunde libremente a las células circundantes (Wang et al., 2002).

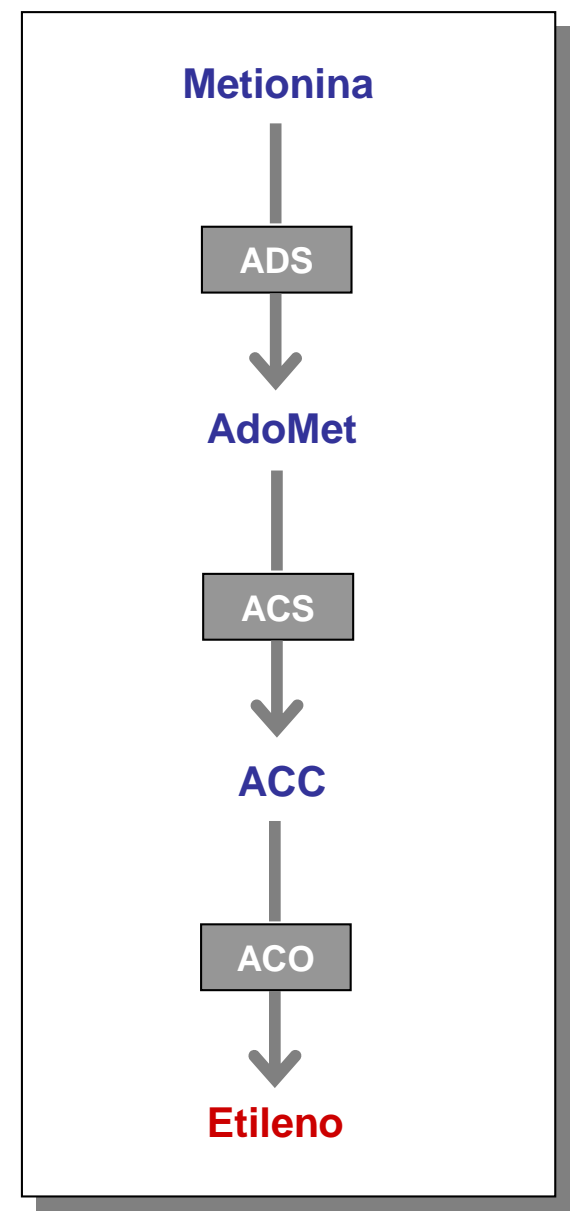

Figura 6. Ruta de biosíntesis del etileno. ADS, AdoMet sintasa; ACS, ACC sintasa; ACC, ácido 1aminociclopropano 1-carboxílico; ACO, ACC oxidasa 


\section{Mecanismo de señalización del ET.}

El etileno producido como consecuencia del ataque patogénico es percibido en la pared celular y esta señal se transmite mediante una cascada de señalización muy conservada en diferentes especies (Chen et al., 2005; Guo y Ecker, 2004; Stepanova y Alonso, 2005). La mayoría de los componentes de dicha ruta han sido descubiertos mediante el empleo de mutantes de Arabidopsis que no responden al ET o bien que poseen una respuesta a ET constitutiva. La respuesta a ET se conoce con el nombre de 'triple respuesta' y morfológicamente se caracteriza por una inhibición del crecimiento del hipocotilo y de la elongación radicular, un estrechamiento radial del hipocotilo y un meristemo apical hipercurvado.

El análisis de mutantes insensibles a ET ha permitido identificar una familia de cinco receptores implicados en las primeras etapas de percepción de la hormona (ETR1, ETR2, ERS1, ERS2 y EIN4) (Bleecker et al., 1988; Chang et al., 1993; Hua, et al., 1995; Hua et al., 1998; Sakai et al., 1998), localizados en la membrana del retículo endoplasmático (Chen et al., 2002; Chen et al., 2005). En ausencia de etileno, estos receptores funcionan como parte de un sistema de regulación negativa de las respuestas a dicha fitohormona (Hua y Meyerowitz, 1998; Rodríguez et al., 1999; Schaller y Bleecker, 1995). Parte fundamental de este sistema de regulación negativa es la proteína CTR1, también localizada en el retículo endoplasmático, y cuyo dominio amino terminal interacciona con el dominio histidina-kinasa de los receptores. Dicha interacción activa la función de CTR1 que transduce la señal de bloqueo de los genes de respuesta a etileno. La unión de etileno al receptor provoca la liberación al retículo endoplasmático de CTR1 produciéndose la interrupción de la señal bloqueante (Gao et al., 2003; Clark et al., 1998). Otro gen implicado en esta ruta de señalización es EIN2, que codifica una proteína integral de membrana, con un dominio hidrofóbico similar al de los transportadores de iones metálicos y otro hidrofílico que podría estar implicado en interacciones proteína-proteína (Alonso et al., 1999). Finalmente, la señal de ET llega al núcleo mediante la desrepresión de EIN2 por parte de CTR1, produciéndose la activación de factores de transcripción del tipo EIN3 (Chao et al., 1997). EIN3 activa la expresión de los denominados factores de respuesta a etileno (ERFs), necesarios para que tenga lugar la expresión de diferentes genes de defensa dependientes de ET, siendo 
algunos de ellos, también dependientes de JA, como PDF1.2 (Norman-Setterblad et al., 2000).

\section{I.1.4.4.- Interacciones entre las rutas de señalización patogénica.}

La convergencia en PDF1.2 de las rutas de JA y ET en plantas de Arabidopsis thaliana es sólo una de las numerosas evidencias que demuestran que las diferentes rutas defensivas de las plantas no funcionan de forma independiente, sino que están implicadas en una compleja red de señalización. La rutas de señalización del JA y del ET parecen actuar de forma sinérgica en las diferentes respuestas defensivas (Ellis y Turner, 2001; Penninckx et al., 1996; Pieterse et al., 1998). Dicho sinergismo ha quedado demostrado mediante los análisis realizados con microarrays que ponen de manifiesto grupos de genes que se inducen de forma común tanto por ET como por JA (Glazebrook et al., 2003; Schenk et al., 2000). Numerosos estudios han demostrado que, mientras el ET y el JA interaccionan sinérgicamente activando programas defensa inducibles, las rutas del ET y del JA actúan de forma antagonista a la ruta dependiente de SA (Broekaert et al., 2006). El antagonismo entre SA y JA/ET probablemente permite a la planta priorizar de forma efectiva las respuestas defensivas dependientes de una u otra señalización (figura 7).

Finalmente, cabría mencionar también que el mecanismo de resistencia ISR (resistencia sistémica inducida) está regulado por JA y ET. Sin embargo, aunque no depende del SA, sí que requiere la acción de NPRl (figura 7), implicado en la activación de los genes $P R$ característicos de la ruta del SA (Pieterse y Van Loon, 1999; Verhagen et al., 2004; Broekaert et al., 2006). 


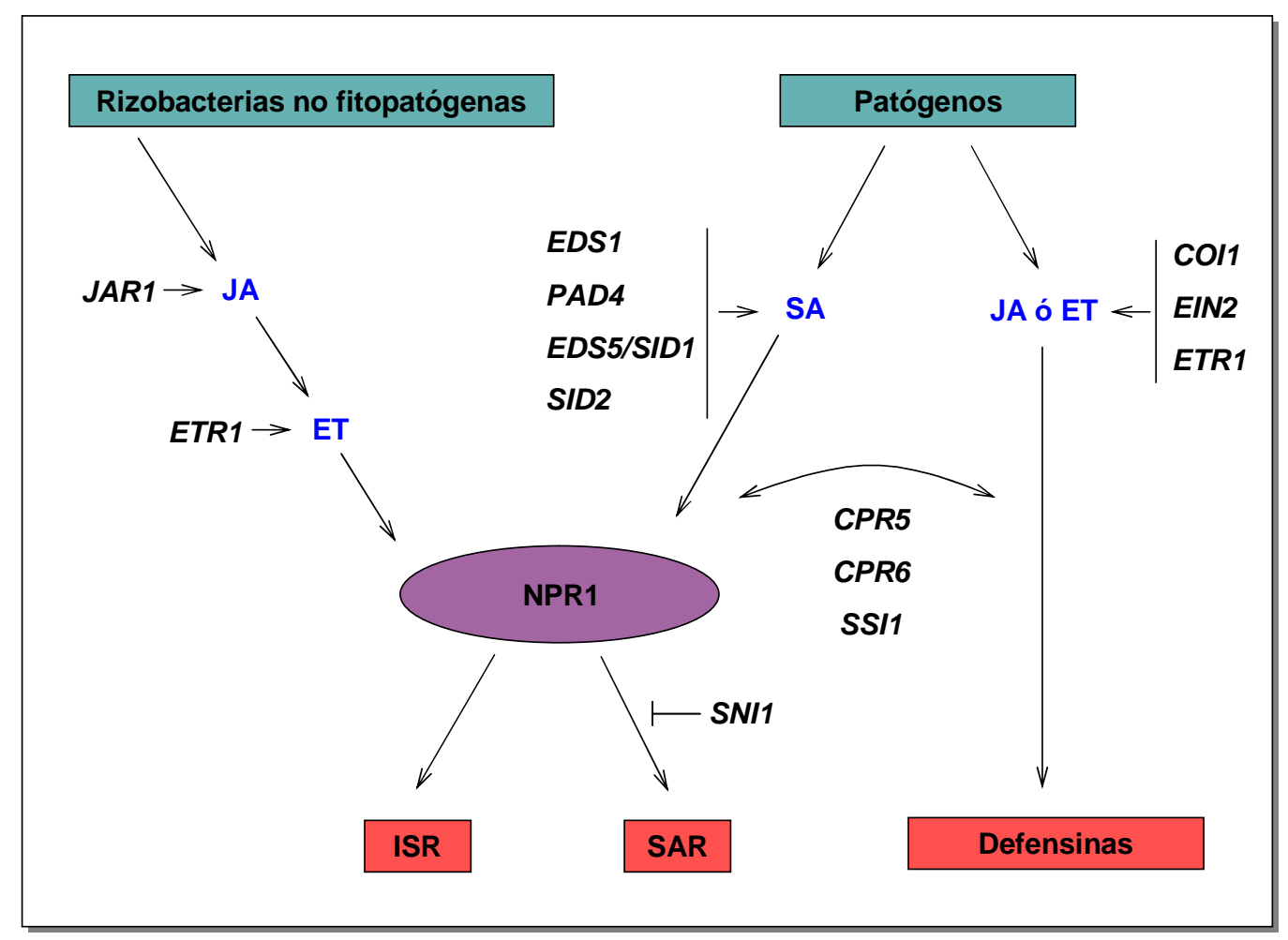

Figura 7. Interacción entre las diferentes rutas de señalización patogénica. JA, ácido jasmónico; JAR1, jasmonic acid response1; ET, etileno; ETR1, ethylene response1; SA, ácido salicílico; EDS1, enhanced disease susceptibility 1; PAD4, phytoalexin deficient4; EDS5/SID1, enhanced disease susceptibility5; SID2, salicylic acid induction defecient2; COI1, coronatine insensitive1; EIN2, ethylene insensitive2; ETR1, ethylene response1; CPR5, constitutive expressor of PR genes5; CPR6, constitutive expressor of PR genes6; SSI1, supressor of SAinsensitivity2; NPR1, non-expressor of PR1-1; SNI1, supressor of npr1-1; ISR, induced systemic resistance; SAR, systemic acquired resistance. Adaptado de Feys y Parker (2000). 


\section{I.1.4.5.- La ruta del ácido gentísico (GA).}

Hace unos años, nuestro laboratorio se interesó en la búsqueda de nuevas moléculas señalizadoras de la respuesta defensiva en plantas. El estudio se centró en compuestos fenólicos ya que, en numerosas ocasiones, ha sido descrita su importancia como armas defensivas per se (Laks y Pruner, 1989; Lyons et al., 1990; Lattanzio et al., 1994; Maher et al., 1994) y como moléculas señalizadoras de la respuesta defensiva, tal es el caso del SA, claramente implicado en el establecimiento de la SAR (Delaney et al., 1994). El sistema elegido fue una interacción de tipo compatible, concretamente plantas de tomate infectadas con el viroide de la exocortis de los cítricos (CEVd) (Conejero y Granell, 1986; Granell et al., 1987). La comparación entre los extractos fenólicos de plantas control y plantas infectadas puso en evidencia la gran acumulación de un compuesto, diferente al SA, identificado por ${ }^{1} \mathrm{HNMR}$ (Proton Nuclear Magnetice Resonance) como ácido gentísico (GA). Con la aparición de los síntomas propios del CEVd, la planta de tomate comenzaba a acumular GA, alcanzando niveles mucho mayores que los de SA (Bellés et al., 1999). Los mismos resultados se obtuvieron en otra interacción de tipo compatible, la resultante de infectar plantas de tomate con el virus del mosaico del tomate (ToMV). Sin embargo, no se observó acumulación de GA y sí de SA, en este mismo huésped, al realizar una infección necrotizante (interacción incompatible) con Pseudomonas syringae pv. syringae (Tabla 1). Por otra parte, al tratar exógenamente con GA, las plantas de tomate mostraban una acumulación de PRs, concretamente de P23, P32 y P34. Estas proteínas no se inducían, en cambio, con SA (Bellés et al., 1999). Todos estos resultados sugerían que el GA podría actuar como una molécula señalizadora, complementaria al SA, en la activación de las defensas en tomate. En este sentido, recientemente, nuestro grupo ha observado que el GA también se induce como consecuencia de infecciones no necrotizantes, en otras especies vegetales, como Gynura aurantiaca y Cucumis sativus, aunque, a diferencia de lo que ocurre en tomate, en estos casos, la acumulación de GA va acompañada de una considerable acumulación de SA (Tabla 1). Por el contrario, al infectar Cucumis sativus con una dosis elevada de Pseudomonas syringae pv. syringae, se produce en la zona inoculada una rápida necrosis (HR-like), que no conlleva un aumento significativo de GA, pero sí de SA. Además, los tratamientos exógenos con GA y SA inducen proteínas defensivas distintas (Bellés et al., 2006). 
El hecho de que el GA induzca proteínas defensivas distintas del SA, junto con su poder antifúngico muy eficaz en plantas (Lattanzio et al., 1994), sugiere que el GA podría actuar como una señal adicional al SA, en la activación de las defensas, en infecciones no necrotizantes. Además, como ya se ha comentado, el GA también es capaz de activar proteínas de estrés en algunos microorganismos, mientras que en células animales, gracias a su poder antioxidante, el GA ejerce un efecto protector importante frente al ataque de ciertas bacterias (Belicova et al., 2001).

\begin{tabular}{|c|c|c|c|c|c|}
\hline $\begin{array}{c}\text { SISTEMA } \\
\text { PLANTA-PATÓGENO } \\
\end{array}$ & $\begin{array}{c}\text { TIPO DE } \\
\text { INTERACCIÓN }\end{array}$ & INFECCIÓN & $\begin{array}{c}\text { INDUCCIÓN } \\
\text { DE GA }\end{array}$ & $\begin{array}{c}\text { INDUCCIÓN } \\
\text { DE SA } \\
\end{array}$ & REFERENCIA \\
\hline Tomate-CEVd & compatible & sistémica & +++ & + & Bellés et al., 1999 \\
\hline Tomate-ToMV & compatible & sistémica & ++ & - & Bellés et al., 1999 \\
\hline Tomate-Pseudomonas syringae & incompatible & $\mathrm{HR}$ & - & + & Bellés et al., 1999 \\
\hline Pepino-PNRSV & compatible & sistémica & ++ & + & Bellés et al., 2005 \\
\hline Pepino-Pseudomonas syringae & incompatible & HR-like & - & + & Bellés et al. , 2005 \\
\hline Gynura-CEVd & compatible & sistémica & ++ & ++ & Bellés et al. , 2005 \\
\hline
\end{tabular}

Tabla 1. Inducción de GA y SA en diferentes interacciones planta-patógeno. 


\section{I.2.- El metabolismo secundario en el sistema defensivo de las plantas.}

Las plantas producen una gran variedad de compuestos orgánicos que participan e influyen en su interacción con el medio que las rodea. Dichos compuestos, denominados tradicionalmente metabolitos secundarios, juegan un papel muy importante en la protección de la planta frente a ataques patogénicos de diversa naturaleza.

Basándonos en sus orígenes biosintéticos podemos establecer tres grandes grupos de compuestos que conforman el metabolismo secundario de una planta: terpenos, alcaloides, y fenilpropanoides (Korkina, 2007). A continuación, se describen las características estructurales de cada grupo así como su implicación en la defensa de las plantas frente a patógenos, con el fin de establecer una panorámica general del papel del metabolismo secundario en el sistema defensivo de las plantas.

\section{I.2.1.- Terpenos.}

Los terpenos, también conocidos con el nombre de terpenoides o isoprenoides, forman un conjunto enormemente amplio de metabolitos secundarios (más de 40.000 descritos hasta la fecha) en plantas, animales y microorganismos (Roberts, 2007). La denominación terpeno proviene del nombre trementina o aguarrás, y se limitó inicialmente a compuestos aislados de ésta y otras esencias naturales, pero luego también se amplió a otras muchas sustancias volátiles y también no volátiles (Buchanan et al., 2002; Marco, 2006).

Todos ellos derivan del 2-metil-1,3-butadieno o isopreno y se caracterizan por contener un número de carbonos múltiplo de 5 , generalmente $10,15,20$ y 30 . Se clasifican tomando como base el número de carbonos de su estructura, sin indicar nada acerca de la misma, en: hemiterpenos $\left(C_{5}\right)$, monoterpenos $\left(C_{10}\right)$, sesquiterpenos $\left(C_{15}\right)$, diterpenos $\left(\mathrm{C}_{20}\right)$, sesterterpenos $\left(\mathrm{C}_{25}\right)$, triterpenos $\left(\mathrm{C}_{30}\right)$, tetraterpenos $\left(\mathrm{C}_{40}\right) \mathrm{y}$ politerpenos $\left(>\mathrm{C}_{40}\right)$. Los monoterpenos y sesquiterpenos fueron conocidos desde muy pronto como constituyentes de esencias vegetales ya que una buena proporción de ellos exhibe una apreciable volatilidad. Un ejemplo de monoterpeno lo encontramos en el ácido crisantémico, componente de los insecticidas naturales llamados piretrinas. Los diterpenos y triterpenos suelen ser constituyentes comunes de gomas, resinas y otros 
exudados vegetales; algunos triterpenos y sus parientes biosintéticos, los esteroides tales como el colesterol, se encuentran también en organismos animales. Un ejemplo muy importante de diterpeno es el ácido giberélico, hormona que juega un papel crucial en el desarrollo de la planta. Los tetraterpenos engloban un amplio grupo de carotenoides, colorantes muy abundantes en el reino vegetal. Los sesterterpenos han sido los últimos en incorporarse a la lista puesto que fueron descubiertos por primera vez a mediados de los años sesenta; su difusión es bastante restringida y se limita a ciertos tipos de esponjas, hongos e insectos, además de algunas plantas superiores. Finalmente, los politerpenos constituyen un grupo relativamente reducido de sustancias con más de 30 átomos de carbono, ampliamente difundidas en las membranas celulares de los organismos vivos (Marco, 2006).

\section{I.2.1.1.- Biosíntesis de los terpenos.}

El precursor de las unidades isoprénicas $\mathrm{C}_{5}$ con las que se construyen los esqueletos terpénicos es el ácido mevalónico, un compuesto de 6 carbonos. Dichas unidades, el isopentenil pirofosfato (IPP) y el dimetilalil pirofosfato (DMAPP), se forman por fosforilación secuencial de los dos hidroxilos alcohólicos del ácido mevalónico mediada por ATP, seguida de una descarboxilación-fragmentación que expulsa $\mathrm{CO}_{2}$ y una unidad de fosfato. El intermedio formado de este modo, el IPP, es isomerizado luego reversiblemente al fosfato alílico DMAPP en un proceso catalizado por un enzima denominado IPP isomerasa. El equilibrio se encuentra desplazado mayoritariamente hacia el DMAPP.

La ruta biosintética de los dos precursores terpénicos base (IPP y DMAPP) a través del ácido mevalónico ha sido considerada durante muchas décadas la única vía existente de formación in vivo de dichos compuestos. Sin embargo, a finales de la década de los ochenta, ciertos experimentos sobre biosíntesis de tripterpenos en bacterias pusieron de manifiesto la existencia de una vía metabólica alternativa que utilizaba 1-deoxi-D-xilulosa 5-fosfato (DXP) como precursor de las unidades isoprénicas $\mathrm{C}_{5}$ IPP y DMAPP. El ácido pirúvico proporciona un fragmento $\mathrm{C}_{2}$ (tras pérdida de $\mathrm{CO}_{2}$ ) y el D-gliceraldehído 3-fosfato proporciona un fragmento $\mathrm{C}_{3}$ a la unidad IPP. El primer paso es una transferencia de anión acetilo al gliceraldehído desde el ácido pirúvico, dando lugar a la DXP. La DXP experimenta una transposición catiónica catalizada por un enzima denominado 1-desoxi-D-xilulosa 5-fosfato 
reductoisomerasa (DXR). El mismo enzima, con ayuda del cofactor NADPH, reduce éste último compuesto dando 2-C-metil-D-eritriol 4-fosfato (MEP), primer intermedio aislado con esquelético $\mathrm{C}_{5}$ isoprénico. La conversión final a IPP o DMAPP requiere dos pasos consecutivos de tipo reductor (Marco, 2006).

En plantas, la formación de terpenos en el citoplasma tiene lugar por la vía metabólica del mevalonato, que es responsable de la síntesis de los triterpenos, incluidos los esteroides, y de muchos sesquiterpenos. Sin embargo, la vía de la DXP es la operativa en los cloroplastos y es responsable de la biosíntesis de los monoterpenos y diterpenos, particularmente el fitol, constituyente de la estructura de la clorofila, así como también de los tetraterpenos (Marco, 2006) (figura 8).

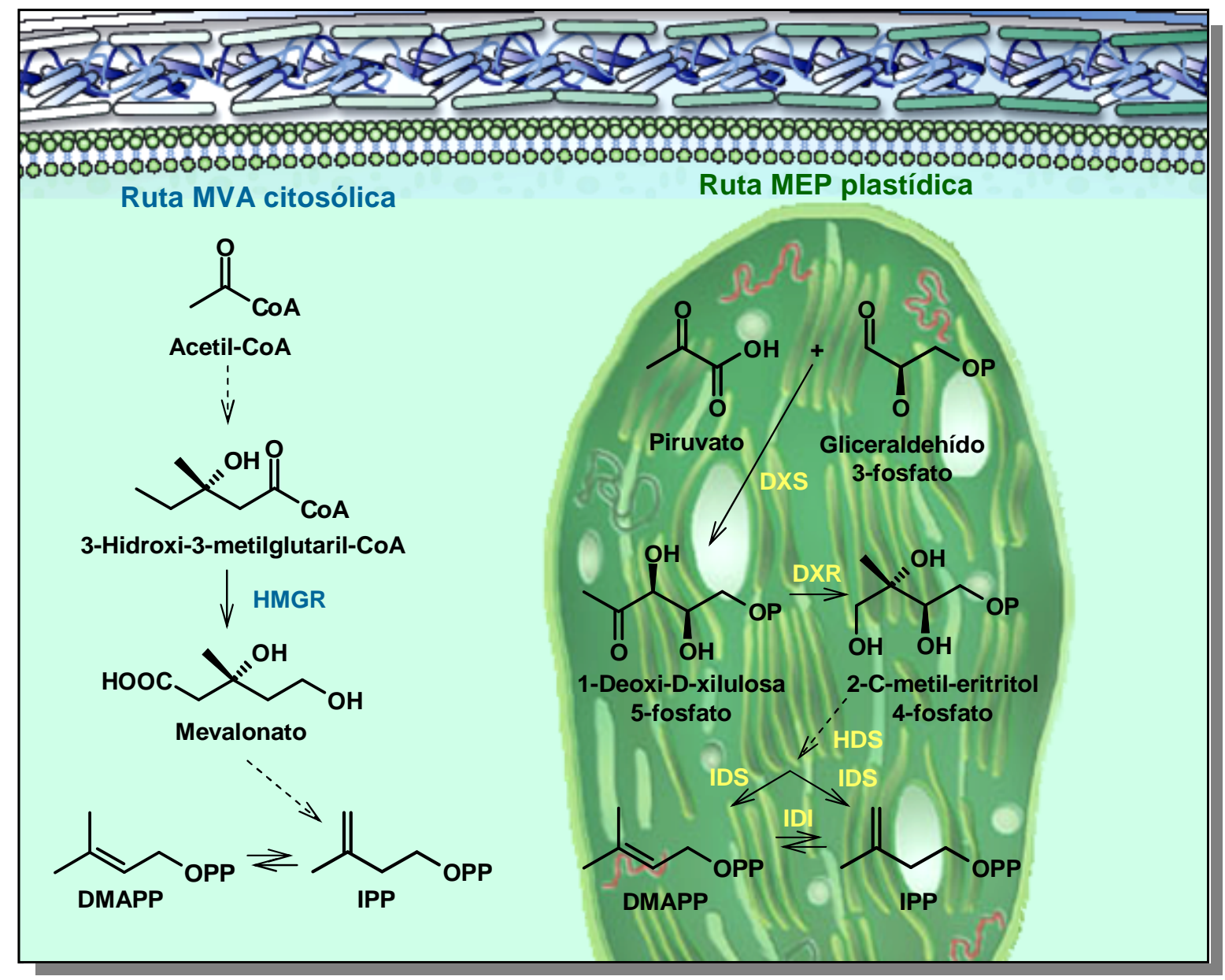

Figura 8. Biosíntesis compartimentada del IPP y del DAMP. A la derecha se muestra la vía del ácido mevalónico (MVA) en el citoplasma. HMGR, 3-hidroxi-3-metilglutaril coenzima A reductasa. A la izquierda se muestra la vía del 2-C-metil-eritritol-4-fosfato (MEP) en el cloroplasto. DXS, 1-deoxi-Dxilulosa-5-fosfato sintasa; DXR, 1-deoxi-D-xylulosa-5-fosfato reductoisomerasa; HDS, hidroxi-2-metil2-€-butenil 4-difosfato sintasa; IDS, isopentenil difosfato dimetilalil difosfato sintasa; IDI, isopentenil difosfato isomerasa. Adaptado de Roberts (2007). 
En realidad, el IPP y el DMAPP no son ellos mismos precursores directos de los terpenos individuales, sino de unos compuestos intermedios que son a su vez precursores específicos de aquéllos. La formación de estos precursores específicos a partir del IPP y del DMAPP es catalizada por enzimas específicos denominado colectivamente preniltransferasas. Las preniltransferasas generan precursores como el geranil difosfato (GPP), precursor de los monoterpenos, el farnesil difosfato (FPP), precursor de los sesquiterpenos, y el geranilgeranil difosfato (GGPP), precursor de los diterpenos. Los enzimas geranil difosfato sintasa (GPPS), farnesil difosfato sintasa (FPPS), y geranilgeranil difosfato sintasa (GGPPS), catalizan la conversión los antedichos precursores en los correspondientes derivados terpénicos (Buchanan et al., 2002; Marco, 2006).

\section{I.2.1.2.- Los terpenos en el sistema defensivo de las plantas.}

Para poder entender completamente el lugar que ocupan los terpenos en el sistema defensivo de las plantas, resulta interesante conocer el modo en el que estas sustancias actúan molecularmente. A continuación se citarán algunos ejemplos que ponen de manifiesto su modo de acción. Los piretroides constituyen un tipo de terpenos de gran interés. Tanto los piretroides de origen natural como los análogos de de origen sintético son importantes insecticidas comerciales debido a su limitada persistencia en el medio ambiente y a su baja toxicidad en mamíferos y aves. Los piretroides actúan sobre el sistema nervioso central de los insectos, alterando los canales de sodio de la membrana de las células nerviosas. De esta manera, se producen repetidas descargas en los nervios, en lugar de impulsos nerviosos simples, produciéndose la hiperexcitación del sistema nervioso, lo cual se traduce en movimientos descoordinados y rápidos y finalmente parálisis (Gershenzon y Dudareva, 2007).

Sin embargo, teniendo en cuenta la gran variedad de terpenos que se conocen en la naturaleza, actualmente se sabe muy poco sobre su modo de acción. Debido a la naturaleza lipofílica de la mayoría de éstos compuestos, se piensa que su principal diana sería la membrana plasmática y su toxicidad se produciría por la perdida del control quimiosmótico por parte de la célula. Otra posibilidad que estaría relacionada con lo anterior, es que los terpenos actúan de forma sinérgica con otras toxinas ayudándolas a atravesar la membrana plasmática de las células (Gershenzon y Dudareva, 2007). Por ejemplo, los monoterpenos presentes en la planta Porophyllum gracile incrementan la 
toxicidad de un compuesto defensivo sintetizado por la planta (poliacetileno) frente al lepidóptero Ostrinia nubilalis (Guillet et al., 1998). El mismo efecto se ha visto sobre ciertos microorganismos. En efecto, la acumulación de una mezcla de sesquiterpenos y monoterpenos en la tradicional hierba china Perilla frutescens aumenta la toxicidad del sesquiterpeno drimano frente una gran variedad de bacterias y hongos (Kang et al., 1992). Existen empresas farmacéuticas que están investigando en este proceso con el fin de desarrollar fármacos que combatan infecciones cutáneas (Kanikkannan et al., 2000).

Por otra parte, tal y como se ha comentado anteriormente, los terpenos constituyen uno de los tipos de compuestos volátiles mayoritarios en flores y en frutos. Sin embargo, las flores y frutos no son los únicos órganos vegetales que acumulan este tipo de metabolitos. Ciertos trabajos han demostrado que la alimentación de los insectos sobre las hojas induce la emisión de una mezcla de compuestos volátiles (VOCs, volatile compounds) formada fundamentalmente por terpenos (Dicke et al., 1990; Turlings et al., 1990). Dichas mezclas de compuestos volátiles constituyen un sistema de comunicación utilizado por la planta con el fin de atraer predadores y parásitos de plagas de insectos que la atacan (Dicke et al., 1990; Turlings et al., 1990; Kessler y Baldwin, 2001). De hecho, se han identificado monoterpenos y sesquiterpenos específicos que participan en este sistema de comunicación (Kessler y Baldwin, 2001; Kappers et al., 2005; Schnee et al., 2006). La emisión de terpenos por parte de la planta también puede servir como mecanismo de señalización interna en la misma que indique la presencia de un insecto y permita la inducción de defensas en los tejidos adyacentes. Por ejemplo, las hojas de lima dañadas por insectos emiten compuestos volátiles que estimulan la secreción de un néctar en los tejidos vecinos que atrae a enemigos naturales de dichos insectos (Heil y Bueno, 2007). Finalmente, la emisión de terpenos volátiles por una planta en respuesta a un ataque por insectos, puede servir para alertar a plantas vecinas de la presencia de una plaga. Existen múltiples ejemplos en la literatura que muestran la inducción de defensas en plantas en respuesta a compuestos volátiles liberados por otras plantas (Baldwin et al., 2006; Dicke y Bruin, 2001; Ton et al., 2007). 


\section{I.2.2.- Alcaloides.}

El término alcaloide, debido al farmacéutico alemán W. Meissner en 1879, significa semejante a los álcalis y se aplica a compuestos nitrogenados básicos naturales, de origen vegetal. Los alcaloides son representantes arquetípicos del metabolismo de las plantas y constituyen un tipo de metabolitos secundarios en los que parte de la estructura, incluyendo el nitrógeno, procede de los aminoácidos. El grado de conservación de la estructura del aminoácido en la del alcaloide es, sin embargo, variable. En la mayoría de los casos se retiene la práctica totalidad de la misma salvo el grupo carboxilo, que suele perderse por lo general. A su vez, el aminoácido puede constituir la totalidad de la estructura del alcaloide o sólo una parte de ésta, proviniendo el resto de la estructura de la vía metabólica del acetato-malonato, de la del ácido shikímico o de algunos precursores isoprénicos $C_{5 n}$ (Marco, 2006). En la figura 9 se muestran algunos de los alcaloides más conocidos. A continuación se realiza una descripción de los diferentes tipos de alcaloides basándonos en sus orígenes biosintéticos.

\section{I.2.2.1.- Biosíntesis de los alcaloides.}

Los alcaloides se clasifican siguiendo un criterio biosintético de acuerdo con el aminoácido y/o compuesto precursor. El número de precursores es bastante reducido y se limita, salvo raras excepciones, a la fenilalanina / tirosina, triptófano, lisina / ornitina, histidina y ácido nicotínico (Marco, 2006). Dada la gran variedad de alcaloides conocidos y las múltiples funciones atribuidas a los mismos, en el presente trabajo se describen únicamente los grupos de alcaloides más relevantes pertenecientes al reino vegetal: alcaloides derivados del triptófano y de precursores terpénicos (terpenoid indol alkaloids, TIAs), alcaloides del tipo bencilisoquinoleínico o derivados de la tirosina (benzilisoquinoline alkaloids, BIAs), y alcaloides derivados del tropano (tropane alkaloids, TPAs) y del ácido nicotínico (Facchini, 2001).

Los TIAs constituyen un grupo de alcaloides formado por aproximadamente unos 3000 compuestos. Un ejemplo dentro de este grupo lo encontramos en la quinina, un fármaco utilizado contra la malaria. Todos ellos exhiben en una parte de la molécula un sistema heterocíclico de tipo indol que proviene del aminoácido triptófano, mientras que el resto proviene un precursor terpénico, concretamente de la secologanina. El 
primer paso en la ruta biosintética de este tipo de alcaloides consiste en la conversión del triptófano en triptamina, una reacción catalizada por el enzima triptófano descarboxilasa (TDC). En la planta Catharanthus roseus, un solo gen codifica dicho enzima (De Luca et al., 1989; Goddijn et al., 1992), mientras que en Campotheca acuminata son dos los genes independientes los que codifican TDC (López-Meyer y Nessler, 1997). El enzima estrictosidina sintasa (STR) cataliza la reacción de condensación entre la triptamina y la secologanina, dando como producto la estrictosidina, el precursor común de todos los TIAs (Facchini, 2001). Algunos autores han demostrado la implicación de este tipo de alcaloides en la defensa de las plantas frente a plagas y patógenos (Luijendijk et al., 1996).

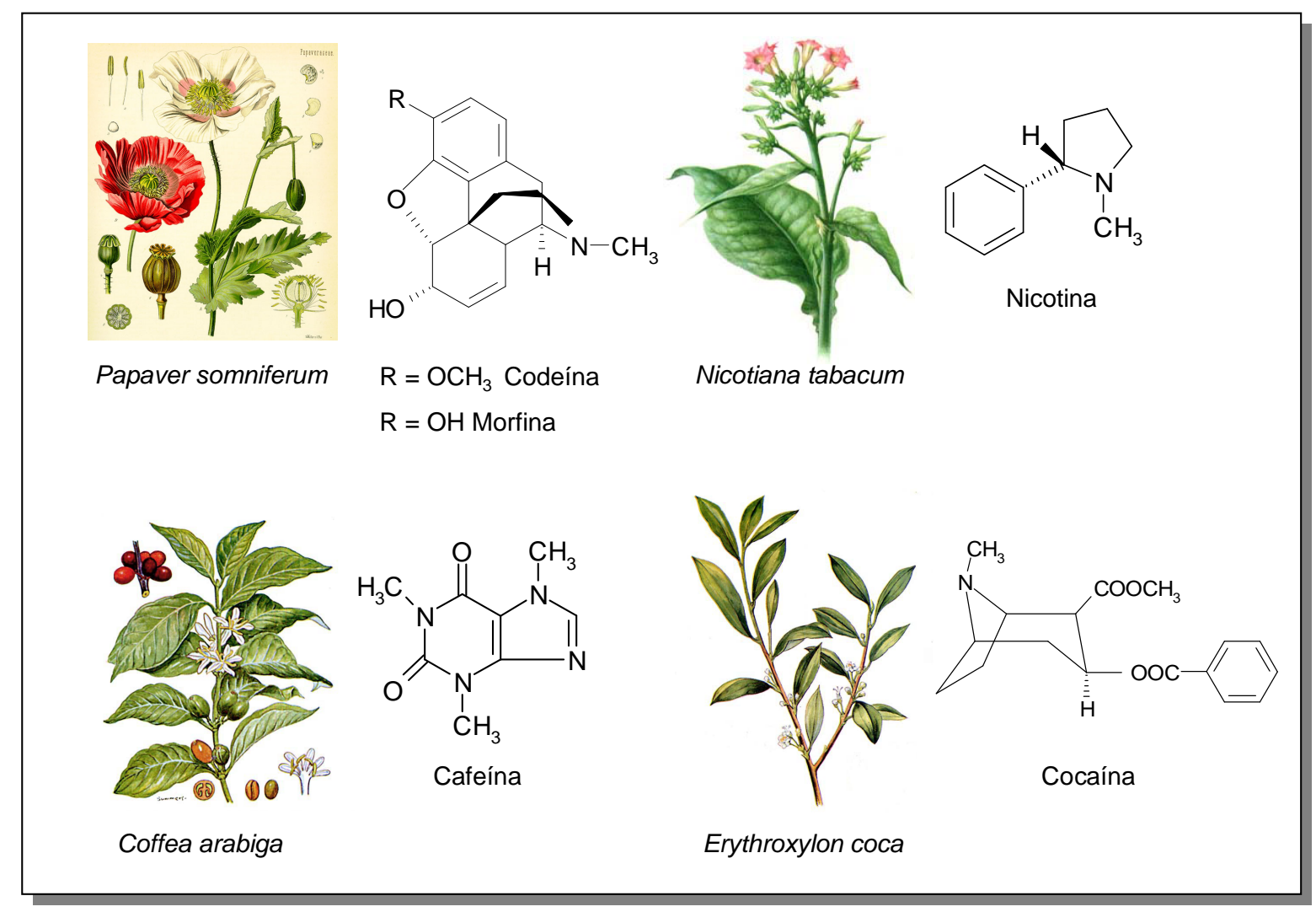

Figura 9. Alcaloides de plantas con diversos orígenes biosintéticos. Adaptado de Buchanan et al. (2002). 
El grupo más importante y numeroso de alcaloides procedentes del aminoácido tirosina es el constituido por los de tipo bencilisoquinoleínico (BIAs). Ejemplos característicos de este grupo son: la morfina, un potente analgésico, la colchicina, un inhibidor del huso acromático, y la codeína. En este caso son dos las moléculas de tirosina las que se incorporan a la estructura del alcaloide, si bien sólo una de ellas proporciona el átomo de nitrógeno. Uno de los primeros pasos en la biosíntesis de este tipo de alcaloides, es la conversión del aminoácido tirosina en dopamina mediante una serie de reacciones de descarboxilación, hidroxilación en orto, y la deaminación, para dar el primero y más sencillo alcaloide del grupo, la norcoclaurina. El enzima implicado en dicha reacción, la tirosina descarboxilasa (TYDC) (Marqués y Brodelius, 1988). La reticulina es otro compuesto clave en la biosíntesis de muchos alcaloides del grupo y es biosintetizada inicialmente con la configuración $S$ en su carbono estereogénico. Notablemente, dicha configuración resulta ser la opuesta a la $R$ que exhibe una parte de dichos alcaloides, muy particularmente los del grupo de la morfina. Ello requiere que se produzca, por tanto, una inversión de la configuración de dicho carbono. Dicha inversión tiene lugar por oxidación mediante un enzima citosólico 1,2-dehidroreticulina reductasa, que es NADPH dependiente (Facchini, 2001).

Los alcaloides derivados del tropano (TPAs) son sintetizados principalmente en plantas de la familia de las Solanáceas. Ejemplos característicos de este grupo los encontramos en la atropina, la hiosciamina, la escopolamina y la cocaína. La síntesis de los TPAs comienza con la descarboxilación de la ornitina y / o arginina para formar la putrescina. Esta primera reacción está catalizada por los enzimas ornitina descarboxilasa (ODC) y arginina descarboxilasa, respectivamente. Aunque la nicotina es un alcaloide que no pertenece a este grupo, el catión N-metil- $\Delta^{1}$-pyrrolinium implicado en la síntesis de los TPAs, es también un intermediario en la ruta de la nicotina. Tanto en el caso de los TPAs como en el caso de la nicotina, el primer paso común en su síntesis consiste en la metilación de la putrescina por parte de la putrescina N-metiltransferasa (PMT). La PMT ha sido clonada en tabaco y muestra una fuerte homología con la espermidina sintasa de humanos $(73 \%)$, ratón $(70 \%)$, y E. coli (58\%) (Hibi et al., 1994). La Nmetilputrescina sufre una reacción de desaminación oxidativa y se transforma en 4aminobutanol que por ciclación espontánea se convierte en el catión N-metil- $\Delta^{1}$ pyrrolinium. Dicho catión sufre una reacción de condensación con el ácido acetoacético 
para formar bien higrina que es el precursor del anillo de tropano, o bien ácido nicotínico, precursor de la nicotina (Facchini, 2001).

Por último, los alcaloides derivados de la purina tales como la cafeína, la teobromina, y la teacrina, se encuentran ampliamente distribuidos en el reino vegetal. Algunos autores (Marco, 2006) emplean la denominación de pseudoalcaliodes para este tipo de compuestos ya que no responden a la definición estricta de alcaloide. En este caso, el aminoácido proporciona únicamente el átomo de nitrógeno a través de un proceso de transaminación, perteneciendo el resto de la estructura a alguna de las grandes rutas metabólicas antes mencionadas (acetato-malonato, de la del ácido shikímico o de algunos precursores isoprénicos $C_{5 n}$ ).

\section{I.2.2.2.- Los alcaloides en el sistema defensivo de las plantas.}

Los alcaloides son un grupo de metabolitos secundarios implicados en el sistema defensivo químico de las plantas tanto constitutivo como induclible. Sus múltiples efectos fisiológicos en posibles predadores y sus actividades antibióticas apoyan dicha hipótesis. Por ejemplo, la nicotina, encontrada en la planta del tabaco, fue uno de los primeros insecticidas utilizados por el ser humano (Luijendijk et al., 1996).. La cafeína presente en la planta del café, en el cacao y en el té, es una efectiva toxina contra insectos. La $\alpha$-solanina, presente en el tubérculo de la patata, es un potente inhibidor de la acetilcolinesterasa.

Por otra parte, tal y como se ha comentado anteriormente, los alcaloides también participan en establecimiento de barreras defensivas de naturaleza química inducibles por patógenos. La $\mathrm{N}$-acetilnicolina se acumula en hojas de tabaco en respuesta a herida o a ataque de insectos. Los niveles de dicho compuesto se incrementan rápidamente (10 horas) para después volver a los niveles basales en un periodo de 14 días aproximadamente. La síntesis inducida de la nicotina y de otros alcaloides parece estar mediada por metil-jasmonato (Buchanan et al., 2002). Además, algunos genes que codifican enzimas implicados en la biosíntesis de alcaloides también experimentan cambios en sus niveles de expresión en respuesta al ataque patogénico. Por ejemplo, se ha comprobado que los niveles de expresión del mRNA de gen de la TYDC se incrementan rápidamente en respuesta a un tratamiento con un elicitor (Facchini et al., 1996; Kawalleck et al., 1993; Trezzini et al., 1993) y en respuesta al ataque patogénico 
(Yamamoto et al., 2000) en diversas especies de plantas. Tal y como se ha comentado anteriormente, la acumulación de TYDC ha sido también descrita en plantas de cebada y Arabidopsis que no acumulan alcaloides derivados de la tirosina. Esto hace pensar que la tiramina, además de ser precursora de los alcaloides de tipo bencilisoquinoleínico (BIAs), podría serlo también de otra clase de metabolitos defensivos. En este sentido, algunos estudios apuntan a que la síntesis y deposición en la pared celular de amidas compuestas por ácido hidroxicinámico y tiramina, es fundamental en la respuesta defensiva de las plantas (McLusky et al., 1999). Sin embargo, este último tipo de compuestos serán estudiados con más detalle en el siguiente apartado.

\section{I.2.3.- Fenilpropanoides.}

Los fenilpropanoides engloban un grupo de metabolitos secundarios de una gran variabilidad tanto estructural como de función (Beggs et al., 1987; Christie et al., 1994; Dixon y Paiva, 1995), producidos por plantas en respuesta a estreses de tipo biótico y abiótico de diversa naturaleza (infecciones patogénicas, respuesta a herida, radiación UV, exposición a ozono, contaminación, etc.). Todos ellos se caracterizan por poseer un esqueleto carbonado del tipo $\mathrm{C}_{6} \mathrm{C}_{3}$. En la figura 10 se muestran algunos fenilpropanoides derivados de plantas y utilizados en la alimentación. Se cree que su principal función en plantas es la de establecer barreras físicas que frenen la expansión del patógeno y también ejercer una acción protectora de las células vegetales frente a la generación de especies de oxígeno activo como consecuencia de una infección patogénica (Korkina, 2007). A continuación se pasará a describir el origen biosintético de este grupo de metabolitos, así como su implicación en la respuesta defensiva de las plantas.

\section{I.2.3.1- Biosíntesis de los fenilpropanoides: la ruta del ácido shikímico.}

Los fenilpropanoides pertenecen a un grupo de compuestos aromáticos naturales derivados del ácido shikímico. El origen de los fenilpropanoides se encuentra en los aminoácidos fenilalanina y tirosina. Bajo la influencia de un enzima, que para el primero de ellos se llama fenilalanina amonio liasa (PAL), dicho aminoácido experimenta una transformación funcional que consiste en la eliminación de amoníaco 
con formación de un doble enlace $\mathrm{C}=\mathrm{C}$, dando lugar al ácido cinámico (figura 11). Curiosamente, la mayoría de las plantas no es capaz de llevar a cabo una transformación semejante del aminoácido tirosina para originar el ácido p-cumárico (o ácido $p$ hidroxicinámico). Una notable excepción son las gramíneas, que pueden hacerlo gracias a que disponen de un enzima denominado tirosina amonio liasa (TAL), equivalente en su efecto al enzima PAL antes mencionado. No obstante, todas las plantas son capaces de biosintetizar ácido p-cumárico por hidroxilación de ácido cinámico (figura 11). Los ácidos cinámico y p-cumárico, son ejemplos arquetípicos de compuestos fenilpropanoides, es decir, del tipo estructural $\mathrm{C}_{6} \mathrm{C}_{3}$. Sirven asimismo de precursores biosintéticos de otros muchos compuestos $\mathrm{C}_{6} \mathrm{C}_{3}$ mediante reacciones de oxidación, reducción, alquilación, etc. (Marco, 2006).

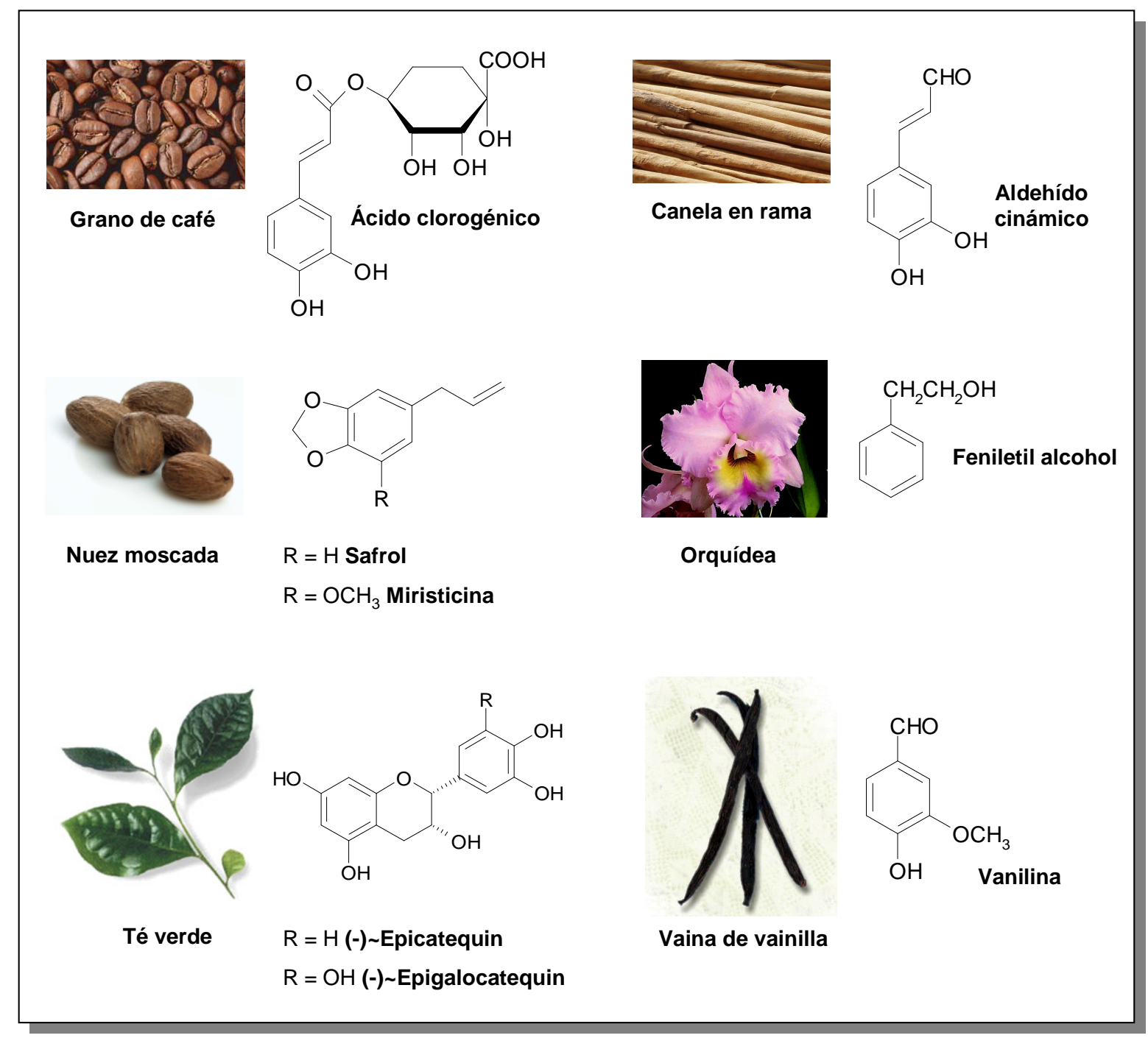

Figura 10. Fenilpropanoides derivados de plantas. Adaptado de Buchanan et al. (2002). 
Muchos de los compuestos fenólicos encontrados en plantas tales como flavonoides, isoflavonoides, cumarinas, y lignanos (figura 11), son productos secundarios del metabolismo de los fenilpropanoides (Korkina, 2007). De particular interés son los alcoholes cinamílicos sustituidos, precursores monoméricos que usan las plantas para la biosíntesis de los lignanos, así como también del importante polímero estructural lignina. Los lignanos son polímeros de naturaleza fenólica que desempeñan un papel muy importante en la impermeabilización de la pared celular al agua, incrementando su rigidez, lo que constituye un mecanismo de resistencia frente a posibles ataques patogénicos. Por otra parte también resulta de interés el ejemplo del resveratrol (un potente antioxidante presente en la uva negra) y el de los flavonoides (responsables de los colores rojos, azules y amarillos que se observan en las flores), ya que ambos poseen un origen biosintético común al de los fenilpropanoides en la ruta del ácido shikímico. En el primer caso, la chalcona sintasa utiliza tres radicales cinamato para producir los distintos tipos de flavonoides que se conocen hasta el momento, mientras que en el caso del resveratrol, es el encima estilbeno sintasa la que utiliza dos radicales cinamato para sintetizar el trans-3,4'-trihidroestilbeno, también conocido como resveratrol (Korkina, 2007).

Las cumarinas (figura 11) son también un grupo muy numeroso de compuestos fenólicos $\mathrm{C}_{6} \mathrm{C}_{3}$ derivados de los fenilpropanoides. De ellos, la cumarina propiamente dicha es la cabeza de serie, y se encuentra en muchas especies vegetales, siendo, por ejemplo, responsable del típico olor del heno recién cortado. Otros compuestos fenólicos de gran interés desde el punto de vista de la defensa de las plantas frente a patógenos y que derivan del metabolismo de los fenilpropanoides, serían el ácido salicílico, y el ácido gentísico, de los que hemos hablado ampliamente en apartados anteriores. Los taninos son un grupo de compuestos naturales presentes en numerosas especies vegetales, causantes del sabor astringente de muchas bebidas. Se sabe que, muy probablemente, la misión que cumplen los taninos en las plantas que los poseen es la de proporcionar una defensa contra las agresiones de hongos e insectos (por toxicidad) y también contra herbívoros (sabor desagradable).

Por último, cabe destacar un grupo de metabolitos, las amidas derivadas del ácido hidroxicinámico (HCAAs), que pertenecen al grupo de los fenilpropanoides, a las 
que se va a dedicar el siguiente capítulo por constituir el eje central de la presente tesis doctoral.

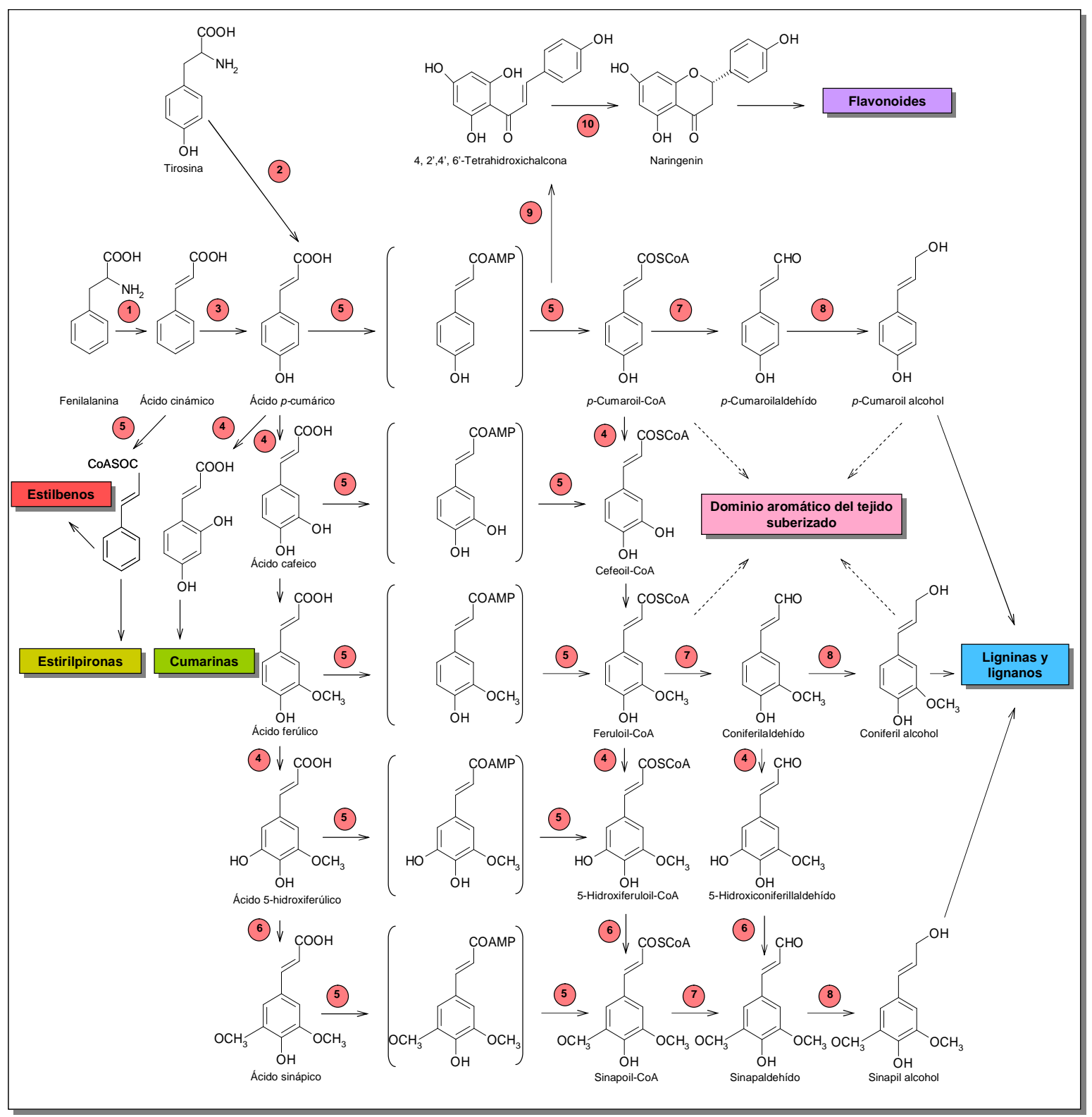

Figura 11. Metabolismo de los fenilpropanoides. Los enzimas son los siguientes: 1, PAL (phenylalanine ammonia-lyase); 2, PAL ó TAL (tyrosine ammonia-lyase); 3, C4H (cinnamate-4-hydroxylase); 4, hidroxilasas; 5, CoA ligasas que participan en la ligación de AMP y CoA (CoASH); 6, $O$-metiltransferasas; 7, cinamoil-CoA:NADPH oxidoreductasas; 8, cinamoil alcohol deshidrogenasas; 9, chalcona sintasa; 10, chalcona isomerasa; 11, estilbeno sintasa; 12, estirilpirona sintasa. Adaptado de Buchanan et al. (2002). 


\section{I.2.3.2.- Metabolismo de las amidas derivadas del ácido hidroxicinámico:} fisiología y bioquímica.

Las amidas derivadas del ácido hidroxicinámico (HCAA, del inglés hydroxycinnamic acid amides) son un conjunto de metabolitos, pertenecientes al grupo de los fenilpropanoides, de bajo peso molecular, y que se caracterizan por la presencia de nitrógeno en su molécula. Basándonos en sus propiedades físicas y químicas podemos distinguir dos tipos de amidas: en primer lugar las amidas básicas, que contienen una función de amina primaria en la molécula y son solubles en agua, y en segundo lugar las amidas neutras, que son insolubles en agua. Normalmente, las amidas básicas contienen en su molécula diaminas y poliaminas alifáticas tales como la putrescina, cadaverina, espermidina y espermina, mientras que el segundo grupo de amidas se caracteriza por contener aminas aromáticas en la molécula como por ejemplo tiramina, octopamina y triptamina (Facchini et al., 2002). En la figura 12 se muestran algunos ejemplos de ambos tipos de amidas.

Las HCAAs están implicadas en una gran variedad de procesos de crecimiento y desarrollo en la planta que serán detallados a continuación. Sin embargo, la función fisiológica mejor caracterizada de este tipo de compuestos, es la de la participación en programas de defensa inducibles como componentes finales de la respuesta defensiva de la planta, como veremos en el siguiente apartado. Un primer rol atribuido a las HCAAs en procesos de crecimiento y desarrollo, está relacionado con la formación de las flores y órganos reproductivos. En efecto, se han identificado una gran variedad de amidas específicas que se acumulan en los tejidos florales (Martin-Tanguy, 1985; Aribaud y Martin-Tanguy, 1994a, 1994b; Tarenghi y Martin-Tanguy 1995), e incluso, los órganos masculinos y femeninos se pueden distinguir en función de sus perfiles metabólicos (Facchini et al., 2002). La obtención de plantas transgénicas transformadas con el plásmido T-DNA Ri de Agrobacterium rhizogenes ha constituido una herramienta básica para estudiar de forma indirecta la implicación de las HCAAs en procesos de desarrollo floral. Dichas plantas se caracterizan por tener alterados la dominancia apical, la morfología foliar, la inducción y el desarrollo floral, y los procesos reproductivos. La expresión constitutiva de dos genes $\mathrm{Ri}$ en tabaco, rolA y rolC, causa esterilidad masculina y reduce la fertilidad femenina (Martin-Tanguy, 1997). Sun y colaboradores (1991) comprobaron que existía una correlación entre dichas alteraciones y la reducción 
en los niveles de acumulación de HCAAs y aminas libres. Los cambios fenotípicos observados en dichas plantas transgénicas se atenúan cuando se aplican exógenamente tiramina o putrescina (Martin-Tanguy, 1997). Otro proceso fisiológico en el que parecen estar implicadas las HCAAs es la tuberización en patata. Paynot y colaboradores (1983) vieron que la acumulación de 4-cumaroilputrescina, cafeoilputrescina, feruloilputrescina, y cafeoilespermidina en los estolones se producía de forma paralela a la formación de los tubérculos.

La conjugación de aminas libres (tiramina, putrescina o similares) en forma de derivados del ácido hidroxicinámico (HCAAs) ha sido propuesta como un mecanismo de regulación de los niveles de poliaminas libres en las células (Flores y Filner, 1985). Un ejemplo lo encontramos en el endosperma de arroz (Oryza sativa): parece ser que las HCAAs derivadas de la putrescina, tiramina y de la espermidina, desempeñan una función de almacenamiento $\mathrm{y}$, después de una hidrólisis, suplementan aminas adicionales requeridas para facilitar la división y la expansión celular durante la germinación de las semillas (Bonneau et al., 1994). Parece ser que, además, la formación de HCAAs podría contribuir a la regulación de la toxicidad de la tiramina en las plantas (Negrel et al., 1993b). El caso anterior no es el único ejemplo que pone de manifiesto la implicación de las HCAAs en procesos de detoxificación. Suzuki y colaboradores (1981), vieron que la acumulación de HCAAs podía estar asociada con la detoxificación de ciertos herbicidas y xenobióticos. Dichos autores comprobaron que un tratamiento en hojas de espinaca (Spinacia oleracea) con herbicidas del tipo difeniléter causaba la acumulación de una amida derivada del ácido ferúlico y de la 3metoxitiramina. 
<smiles>[R2]c1cc(/C=C/C(=O)NCC([R7])c2ccc(O)cc2)ccc1O</smiles>

$\mathrm{R} 1=\mathrm{H} ; \mathrm{R} 2=\mathrm{H} ;$-cumaroiltiramina

$\mathrm{R} 1=\mathrm{OH} ; \mathrm{R} 2=\mathrm{H} ;$-cumaroiloctopamina

$\mathrm{R} 1=\mathrm{H} ; \mathrm{R} 2=\mathrm{OCH}_{3}$; feruloiltiramina<smiles>[R]c1cc(/C=C/C(=O)NCCC2CNc3ccccc32)ccc1O</smiles>

$\mathrm{R}=\mathrm{H} ; p$-cumaroiltriptamina

$\mathrm{R}=\mathrm{OCH}_{3}$; feruloiltriptamina<smiles>[R]c1cc(/C=C/C(=O)NCCCCN)ccc1O</smiles>

$\mathrm{R}=\mathrm{H}$; $p$-cumaroilputrescina

$\mathrm{R}=\mathrm{OCH}_{3}$; feruloilputrescina<smiles>[R]c1cc(/C=C/C(=O)NCCCCNC(=N)N)ccc1O</smiles>

$\mathrm{R}=\mathrm{H}$; p-cumaroilagmatina

$\mathrm{R}=\mathrm{OCH}_{3}$; feruloilagmatina<smiles>[R]c1ccc(C(=O)[O-])c(NC(=O)c2ccccc2)c1</smiles>

$\mathrm{R}=\mathrm{H}$; Diantramida $\mathrm{B}$

$\mathrm{R}=\mathrm{OCH}_{3}$; Metoxidiantramida<smiles>[R7]c1ccc(NC(=O)/C=C/c2ccc(O)c([R2])c2)c(C(=O)O)c1</smiles>

$\mathrm{R} 1=\mathrm{OH} ; \mathrm{R} 2=\mathrm{H}$; avenantramida $\mathrm{A}$

$\mathrm{R} 1=\mathrm{OH} ; \mathrm{R} 2=\mathrm{OCH}_{3}$; avenantramida $\mathrm{B}$

$\mathrm{R} 1=\mathrm{H} ; \mathrm{R} 2=\mathrm{H}$; avenantramida $\mathrm{C}$<smiles></smiles>

Avenalumin I<smiles>[R]c1cc(CCC(=O)O[C@@H]2C[C@](O)(C(=O)O)C[C@H](O)[C@H]2O)ccc1O</smiles>

$\mathrm{R}=\mathrm{H}$; p-cumaroilshikimato

$\mathrm{R}=\mathrm{OH}$; cafeoilshikimato

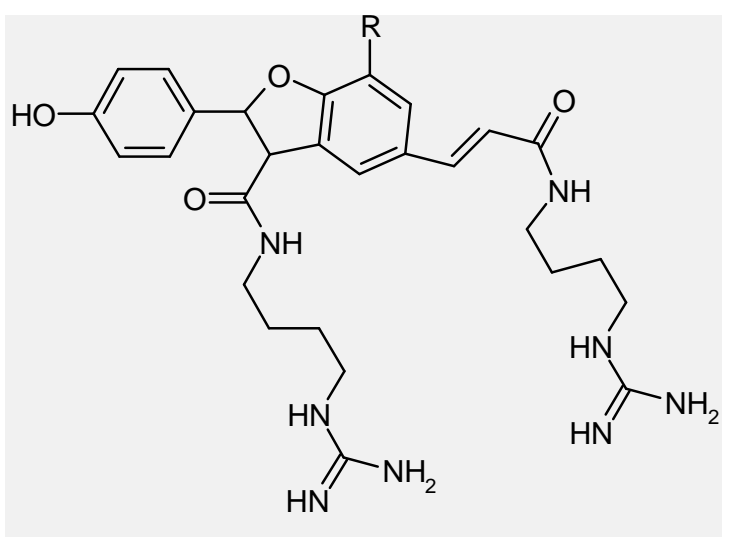

$\mathrm{R}=\mathrm{H}$; Hordatina $\mathrm{A}$

$\mathrm{R}=\mathrm{OCH}_{3}$; Hordatina $\mathrm{B}$

Figura 12. Estructura química de algunas amidas del ácido hidroxicinámico (HCAAs) de plantas. Adaptado de Facchini et al. (2002). 
La feruloiltiramina y derivados son sintetizados a través de la condensación de feruloil-CoA con la tiramina. Los ésteres del ácido hidroxicinámico y la CoA, y la tiramina, derivan del aminoácido fenilalanina y de la tirosina, respectivamente. La formación de dichos ésteres, catalizada por la cumarato CoA ligasa (4CL), es específica de plantas y representa parte del metabolismo general de los fenilpropanoides (Hahlbrock y Scheel, 1989) que, como se ha comentado anteriormente, comienza con la desaminación de la fenilalanina a ácido trans-cinámico mediante el enzima PAL. Además, tal y como se explicó en el apartado de la biosíntesis de alcaloides, la TYDC (tirosina descarboxilasa) cataliza la conversión del aminoácido tirosina en tiramina. Finalmente, la condensación de los ésteres del ácido hidroxicinámico y CoA, con la tiramina, es catalizada por el enzima tiramina hidroxicinamoil transferasa (THT, EC 2.3.1.110) (figura 13). La THT fue aislada por vez primera en hojas de tabaco (Nicotiana tabacum) infectadas con el virus del mosaico del tabaco (Negrel y Martin, 1984). Posteriormente, los cDNAs de la THT han sido clonados en patata (Schmidt et al., 1999), tabaco (Farmer et al., 1999), pimiento (Back et al., 2001) y en tomate (von Roepenack-Lahaye et al., 2003). La cinética y la especificidad de este enzima han sido ampliamente estudiadas en varias especies vegetales (Negrel y Martin, 1984; Negrel y Javelle, 1997; Facchini et al., 2002; von Roepenack-Lahaye et al., 2003). 


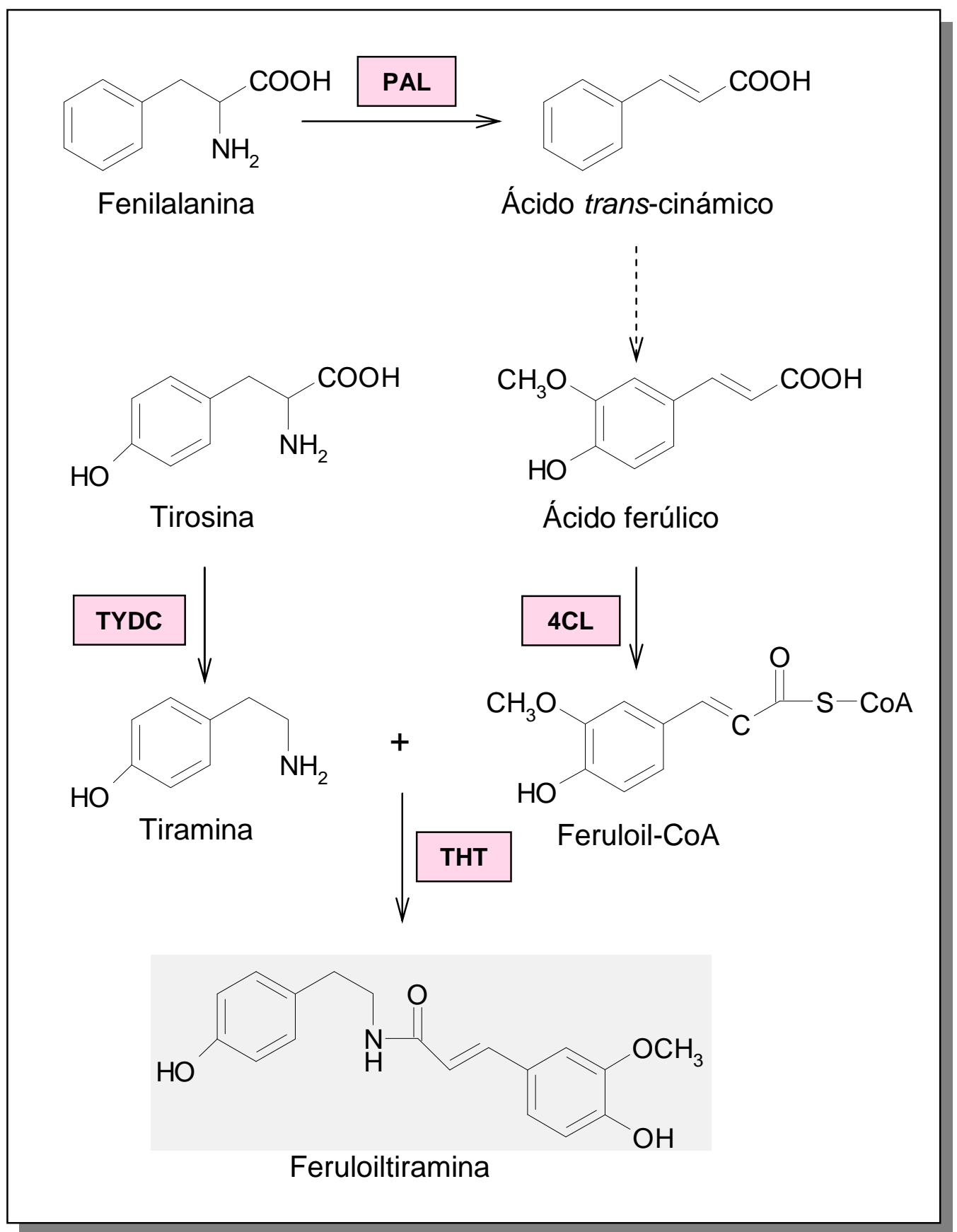

Figura 13. Biosíntesis de feruloiltiramina a partir de tirosina. 4CL, 4-cumarato ligasa; PAL, fenilalanina amonio liasa; THT, tiramina hidroxicinamoil transferasa; TYDC, tirosina descarboxilasa. 
I.2.3.3.- Los fenilpropanoides en el sistema defensivo de las plantas: la importancia de las HCAAs.

Las posibles funciones de los fenilpropanoides que se han propuesto dentro del marco defensivo de las plantas se han basado tradicionalmente en actividades biológicas detectables in vitro y en correlaciones entre ratios de acumulación y expresión de la resistencia in vivo. Así, se ha relacionado la acumulación de este tipo de metabolitos con diversas funciones defensivas tales como el endurecimiento de la pared celular (lignanos), actividad antimicrobiana (furanocumarinas, pterocarpanos, isoflavonoides, HCAAs) y la ya mencionada señalización de la respuesta defensiva (SA, GA) (Hummerschmidt, 1999).

Dentro del grupo de los fenilpropanoides, las HCAAs parecen desempeñar un papel fundamental como parte de las defensas activas en repuesta al ataque patogénico o a herida. Clarke en 1982, mostró por primera vez la acumulación de HCAAs en respuesta a una infección (en tubérculos de patata infectados con Phytophthora infestans). En este sentido, Keller et al. (1996) encontraron que, en plantas de patata (Solanum tuberosum cv. Datura) infectadas con el oomiceto Phytophthora infestans se producen cambios en el patrón de acumulación de compuestos fenólicos pertenecientes a la ruta de los fenilpropanoides, pudiéndose distinguir entre compuestos solubles y compuestos asociados a pared celular. El incremento observado en la producción de compuestos unidos a pared celular después de realizar la infección constituye una barrera química frente al patógeno, ya que se produce una disminución de la digestibilidad de paredes celulares. Además, los compuestos unidos a pared celular pueden también inhibir el crecimiento de invasores fúngicos potenciales. En este contexto, resulta conveniente resaltar que diversos grupos de investigación han observado una disminución de la actividad de enzimas degradativas de la pared celular cuando ésta posee un contenido elevado de compuestos fenólicos (Beimen et al., 1992; Kauss et al., 1993).

Dos de los compuestos unidos a pared celular detectados en patata por Keller et al. (1996) han sido también detectados en tomate por Pearce et al. (1998), inducidos por herida en las hojas. Se trata de dos HCAAs, la p-coumaroiltiramina ( $p$-CT) y la feruloiltiramina (FT). Se ha demostrado que tanto la $p$-CT como la FT son los componentes principales del anillo aromático de la suberina (Bernards et al., 1995; 
Negrel et al., 1996), que se forma como una barrera física al avance de los patógenos en respuesta a herida. Hahlbrock y Scheel (1989) encontraron que la THT estaba implicada en reacciones de resistencia frente a ataques patogénicos en patata. Se vio además que los productos de la reacción catalizada por el enzima eran incorporados a la pared celular (Negrel y Martin, 1984; Villegas y Brodelius, 1990; Negrel et al., 1993a), aparentemente como parte de una barrera defensiva contra la expansión del patógeno. Más recientemente, Von Roepenack-Lahaye et al. (2003) han encontrado que en plantas de tomate Río Grande infectadas con Pseudomonas syringae pv. tomato, se produce la acumulación de p-cumaroiloctopamina y p-cumaroilnoradrenalina, y que la acumulación de dichos metabolitos estaba relacionada con un aumento en los niveles de expresión del gen $T H T$.

La deposición de HCAAs en la pared celular reduce la digestibilidad de la misma y hace más difícil la penetración de ciertos hongos en las células. La síntesis de HCAAs parece producirse en el citosol. Sin embargo, se conoce muy poco acerca del mecanismo de transporte de las mismas hasta la pared celular. En este sentido, McLusky y colaboradores (1999) postularon que las HCAAs son transportadas en vesículas específicas desde el citosol hasta la membrana plasmática donde son liberadas para incorporarse a la pared celular. Sobre el mecanismo de transporte subcelular de este tipo de metabolitos se conoce muy poco, sin embargo existen estudios (Park y Facchini, 2000) que implican a las glutatión $S$-transferasas (GSTs) como proteínas transportadoras de HCAAs. Además, se sabe que la incorporación de las HCAAs a la pared celular requiere la actividad de peroxidasas (Iiyama et al., 1994; Negrel y Lherminier, 1987; Negrel et al., 1996) que a su vez están reguladas por cambios localizados del $\mathrm{pH}$ celular y de los niveles de $\mathrm{Ca}^{2+}$.

Por último, la obtención de plantas transgénicas que sobreexpresen alguno de los enzimas implicados en la ruta de biosíntesis de las HCAAs, ha resultado una importante herramienta para profundizar en el conocimiento del papel de estos compuestos en el sistema defensivo de las plantas (Facchini et al., 1999; Guillet y de Luca, 2005; Hagel y Facchini, 2005; Jang et al., 2004; Lee et al., 2007). Asimismo, dicha estrategia podría constituir un medio de obtención de plantas más resistentes frente a ataques patogénicos de diversa naturaleza. Lo que se ha comentado hasta ahora pone de manifiesto la importancia de este tipo de metabolitos secundarios, las HCAAs, dentro del marco 
defensivo de las plantas. Sin embargo, es necesaria la realización de más trabajos de investigación que permitan profundizar en el conocimiento del metabolismo de dichos compuestos y en su modo de acción. El metabolismo de las HCCAs constituye actualmente una importante área de investigación y una posible diana de manipulación genética. 
II. Objetivos 


\section{Objetivos.}

Una de las líneas de investigación del laboratorio donde se ha realizado la presente tesis doctoral estaba dirigida a la búsqueda de nuevas señales entre compuestos de naturaleza fenólica diferentes al ácido salicílico. En este marco se había producido el descubrimiento del ácido gentísico como nueva molécula señal, inducible por patógenos y con actividad inductora de proteínas PR de defensa. Después de este primer éxito nos planteamos proseguir la búsqueda de nuevas moléculas de naturaleza fenólica implicadas en la respuesta antipatogénica.

Los objetivos concretos que se persiguen en el presente trabajo son los que se detallan a continuación:

1. Identificación y caracterización de nuevas moléculas pertenecientes al metabolismo secundario acumuladas en tomate 'Rutgers' como consecuencia de la infección con Pseudomonas syringae pv. tomato.

2. Estudio de la posible implicación del ácido salicílico y del etileno en la inducción patogénica de dichas moléculas y del enzima responsable de su biosíntesis.

3. Estudio de su actividad antibacteriana y antioxidante in vitro.

4. Obtención de plantas transgénicas que sobreexpresen el enzima responsable de la síntesis de dichas moléculas para el estudio de su posible papel en el marco defensivo de la planta. 


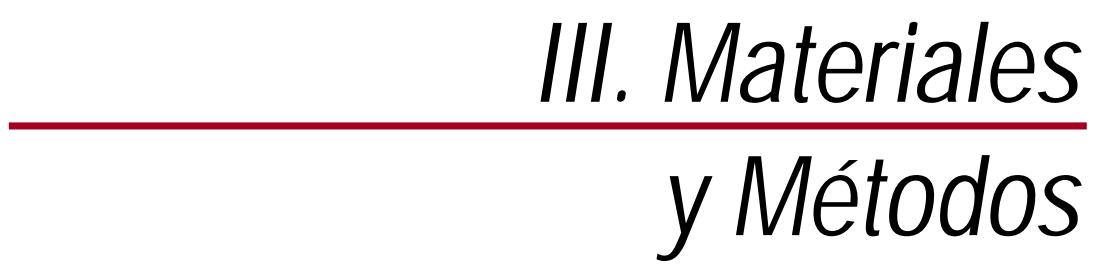




\section{Materiales y métodos.}

\section{III.1.- Material vegetal, condiciones de cultivo y tratamientos.}

Para la realización del presente trabajo se han empleado plantas de tomate (Solanum lycopersicum), cultivares 'Rutgers', UC82, Moneymaker, así como plantas de tomate transgénicas $N a h G$, obtenidas a partir del cultivar Moneymaker y proporcionadas por el Prof. Jonathan D.G. Jones (John Innes Centre, Norwich, UK). El cultivar 'Rutgers' se caracteriza por su sensibilidad frente a ataques patogénicos de distinta naturaleza, y por tanto, ha sido utilizado en estudios previos sobre patogénesis en tomate en nuestro laboratorio (Conejero et al., 1990; Bellés et al., 1999).

El cultivar Moneymaker ha sido utilizado por dos motivos: en primer lugar para comprobar si la inducción de los metabolitos observada en 'Rutgers' como consecuencia de la infección es extensible a otras variedades de tomate y, en segundo lugar, porque dicho cultivar ha sido empleado como fondo genético para desarrollar las plantas transgénicas $N a h G$ (Brading, 2000). Las plantas de tomate $N a h G$, que se caracterizan por no poder acumular ácido salicílico, expresan de forma constitutiva un gen bacteriano que codifica el enzima salicilato hidroxilasa. Dicho enzima convierte el SA en catecol evitando así la acumulación de ácido salicílico (Gaffney et al., 1993; Delaney et al., 1994). La variedad UC82 ha sido empleada para la obtención de plantas transgénicas.

Todas las plantas empleadas fueron cultivadas en invernadero a una temperatura que oscilaba entre los 25 y los $30^{\circ} \mathrm{C}$, con una humedad relativa entre el 50-70\% y con un fotoperíodo de $16 \mathrm{~h}$ luz / $8 \mathrm{~h}$ oscuridad. Se preparaban en primer lugar semilleros en vermiculita y, aproximadamente una semana después de la siembra, las plántulas se transplantaban a macetas que contenían turba y vermiculita al 50\%. Se transplantó una planta por maceta (12 cm de profundidad x $13 \mathrm{~cm}$ de diámetro interior). Las plantas se sometieron a riego a manta automatizado dos veces al día en solución de Hoagland, tal y como se describe en Naranjo et al. (2003). 
Las plantas de Arabidopsis thaliana Columbia-0 fueron cultivadas en cámara bajo condiciones de alta intensidad lumínica (22.000 lux), con un fotoperíodo de 16 horas de luz / 8 horas de oscuridad y $22^{\circ} \mathrm{C}$ de temperatura.

Los tratamientos con ácido salicílico (SA) se efectuaron pulverizando plantas de tomate 'Rutgers' de un mes con una solución de SA (sal sódica) a dos concentraciones diferentes: 1 y $5 \mathrm{mM}$, añadiendo un $0.05 \%$ de Tween 20 para facilitar el contacto de la disolución acuosa con la superficie foliar. Las hojas se pulverizaron hasta estar bien empapadas de la solución. Se recogieron muestras a diferentes horas post-tratamiento (hpt): 5, 24, 30, 48, y 72 .

Los tratamientos con etileno se efectuaron introduciendo plantas de tomate 'Rutgers' de un mes en cajas de metacrilato con una capacidad de 125 1, en una cámara de cultivo a $25^{\circ} \mathrm{C}$ y con fotoperíodo de $16 \mathrm{~h}$ luz / $8 \mathrm{~h}$ oscuridad. Se hizo pasar un flujo constante $(15 \mathrm{l} / \mathrm{h})$ de una mezcla de etileno en aire $(50 \mu \mathrm{l} / \mathrm{l})$ (Lynde), durante 24 horas.

El tratamiento con aminoetoxi-vinilglicina (AVG) se efectuó pulverizando plantas de tomate 'Rutgers' de un mes con una solución de AVG $1 \mathrm{mM}$, añadiendo un 0.05\% de Tween 20 para facilitar el contacto de la disolución acuosa con la superficie foliar. Se realizaron dos tratamientos consecutivos, con 10 horas de diferencia entre uno y otro. Dos horas después del segundo tratamiento las plantas fueron inoculadas con la bacteria Pseudomonas syringae pv. tomato, tal y como se describe en el apartado 2 del presente capítulo. Se recogieron muestras a diferentes tiempos post-inoculación (hpi): 5 , $17,24,48$ у 72 .

\section{III.2.- Inoculación del material vegetal y recogida de muestras.}

Se inocularon plantas de tomate en estado de 4-5 hojas verdaderas con la bacteria Pseudomonas syringae pv. tomato portadora del gen de avirulencia avrPto (Martin et al., 1993). Las bacterias fueron crecidas durante toda la noche a $28^{\circ} \mathrm{C}$ en placas Petri de $20 \mathrm{ml}$ que contenían medio KB (por cada $1000 \mathrm{ml}$ de medio KB: 40 g de proteosa peptona, $20 \mathrm{~g}$ de glicerol, $980 \mathrm{ml}$ de agua, $10 \mathrm{ml}$ de $\mathrm{K}_{2} \mathrm{HPO}_{4}$ al 10\%, y $10 \mathrm{ml}$ de $\mathrm{MgSO}_{4}$ al 10\%). A continuación se recogió una colonia aislada y se sembró en $10 \mathrm{ml}$ de medio LB líquido (Pronadisa), dejándose en agitación a $220 \mathrm{rpm}$ y a $28^{\circ} \mathrm{C}$ durante una noche. El cultivo bacteriano resultante fue resuspendido en sulfato de magnesio 10 
$\mathrm{mM}$ hasta una absorbancia final de 0.1 a $600 \mathrm{~nm}$, lo que se traduce en 1 x $10^{7}$ unidades formadoras de colonia por $\mathrm{ml}(\mathrm{ufc} / \mathrm{ml})$. Aproximadamente $100 \mu \mathrm{l}$ de la suspensión bacteriana final se infiltró en la superficie abaxial de las dos primeras hojas con una jeringuilla estéril de plástico en tres o cuatro zonas diferentes de cada foliolo con un área aproximada de $35 \mathrm{~mm}^{2}$. Los controles se infiltraron del mismo modo, con una solución de sulfato de magnesio $10 \mathrm{mM}$.

La toma de muestras del material vegetal infectado se detalla a continuación:

\section{III.2.1.- Hojas enteras.}

Se recogieron aproximadamente $0.5 \mathrm{~g}$ de hoja infectada por planta (2-3 foliolos infectados) y sus correspondientes controles, a diferentes tiempos después de la inoculación $\left(17,24,30,48\right.$ y 72 hpi). El material recogido se congeló a $-80^{\circ} \mathrm{C}$ hasta la realización de las extracciones de compuestos fenólicos y de RNA.

\section{III.2.2.- Manchas necróticas y zona alrededor de las mismas.}

Con el fin de conocer el área de acumulación de los compuestos objeto de estudio, se decidió diferenciar dos zonas para la recogida de muestras: las manchas necróticas, que incluían el área infiltrada más $1 \mathrm{~mm}$ de tejido adyacente sin inocular (zona A, esquema 1), y el resto de la hoja donde no se había infiltrado la bacteria (Zona B, esquema 1). Las manchas necróticas se recortaron del resto de la hoja con ayuda de un bisturí y, del mismo modo que con las hojas enteras, se recogieron aproximadamente $0.5 \mathrm{~g}$ por planta a diferentes tiempos después de la inoculación (17, 24, 30, 48, 72 hpi). Igualmente, se recogieron $0.5 \mathrm{~g}$ aproximadamente del área de la hoja que no había sido infiltrada con la bacteria. Las muestras recogidas se congelaron a $-80^{\circ} \mathrm{C}$ hasta la realización de las extracciones de compuestos fenólicos.

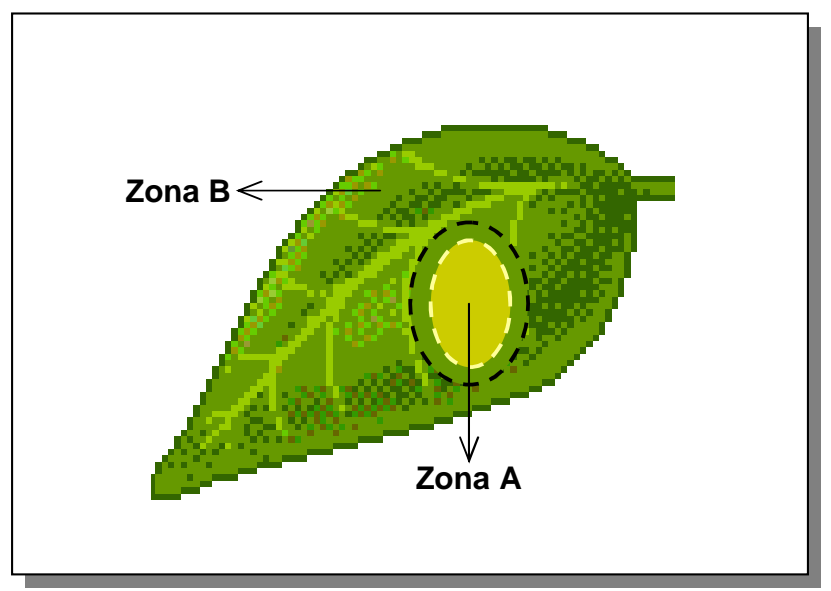

Esquema 1. Zonas de recogida de muestras. Zona A, area infiltrada con la solución bacteriana más 1 $\mathrm{mm}$ de tejido adyacente $\sin$ inocular Zona B, resto de la hoja. 
En el caso de Arabidopsis thaliana se inocularon plantas de 1 mes con la bacteria Pseudomonas syringae pv. tomato RpmI siguiendo el protocolo descrito para tomate. Los controles se infiltraron del mismo modo, con una solución de sulfato de magnesio $10 \mathrm{mM}$. Se recogieron las hojas infectadas y sus correspondientes controles 24 horas después de la inoculación.

\section{III.3.- Extracción de compuestos fenólicos.}

\section{III.3.1.- Compuestos fenólicos libres.}

Cada muestra $(0.5 \mathrm{~g})$ se trituró en un mortero y mazo de porcelana con nitrógeno líquido, para facilitar su homogeneización. Una vez trituradas las muestras se adicionaron $1.5 \mathrm{ml}$ de metanol. A continuación la mezcla se pasó a tubos Eppendorf de $2 \mathrm{ml}$ y se sometió a ultrasonidos durante $10 \mathrm{~min}$. Las ondas que produce el sonicador ayudan a terminar de romper las células, facilitando de este modo la extracción. Posteriormente, las distintas muestras se centrifugaron a $14000 \mathrm{~g}$ durante $15 \mathrm{~min}$. Se recogió el sobrenadante y se pasó a viales de vidrio de $4 \mathrm{ml}$. Las muestras se secaron en corriente de nitrógeno seco a temperatura ambiente. Una vez secas, las muestras se resuspendieron en $1 \mathrm{ml}$ de ácido perclórico al 5\% y a continuación se añadieron $2.5 \mathrm{ml}$ de una mezcla de acetato de etilo y ciclopentano (1:1, v/v), formándose dos fases inmiscibles; los compuestos fenólicos de interés se encuentran en la fase orgánica superior que se recogió y se secó con corriente de $\mathrm{N}_{2}$ seco en las mismas condiciones descritas anteriormente. Las muestras secas se resuspendieron en $200 \mu$ de metanol y se filtraron con ayuda de una jeringa de plástico de $1 \mathrm{ml}$ a la que se le acopló un filtro de nylon de $13 \mathrm{~mm}$ y $0.45 \mu \mathrm{m}$ de poro (Waters). De este modo, las muestras quedaron preparadas para el análisis por HPLC y por espectrofotometría de masas.

\section{III.3.2.- Compuestos fenólicos conjugados.}

Los compuestos fenólicos conjugados se determinaron tras ser liberados por hidrólisis en diferentes condiciones. Se realizaron diferentes tipos de hidrólisis de tipo enzimático: con $\alpha$-glucosidasa, $\beta$-glucosidasa y esterasa. La hidrólisis enzimática con $\alpha$-glucosidasa se utiliza para detectar la presencia de compuestos conjugados en forma 
de $\alpha$-glucósidos (figura 14), la hidrólisis enzimática con $\beta$-glucosidasa se utiliza para detectar la presencia de compuestos fenólicos conjugados en forma de $\beta$-glucósidos (figura 14) y la hidrólisis enzimática con esterasa se utiliza para detectar compuestos fenólicos conjugados en forma de ésteres.

Las extracciones se realizaron del mismo modo que en el apartado anterior hasta el momento del primer secado de las muestras en corriente de nitrógeno seco. A continuación se añadió $1 \mathrm{ml}$ de tampón fosfato $(0.1 \mathrm{M}, \mathrm{pH} 6.5), 1 \mathrm{ml}$ de tampón acetato de sodio (0.1 M, pH 4.5) o $1 \mathrm{ml}$ de tampón Tris- $\mathrm{HCl}(0.1 \mathrm{M}, \mathrm{pH}$ 8) con el enzima (Fluka) $\alpha$-glucosidasa, $\beta$-glucosidasa o esterasa, respectivamente, a una concentración de $4 \mathrm{mg} / \mathrm{ml}$. La mezcla se dejó a $37^{\circ} \mathrm{C}$ durante una hora. A continuación se adicionaron $77 \mu 1$ de ácido perclórico (70\% v/v) para alcanzar una concentración final del 5\%. Entonces, se realizó una extracción líquido-líquido con ciclopentano/acetato de etilo $(1: 1, v / v)$ y se procedió del mismo modo que en el caso de la extracción de compuestos fenólicos libres.

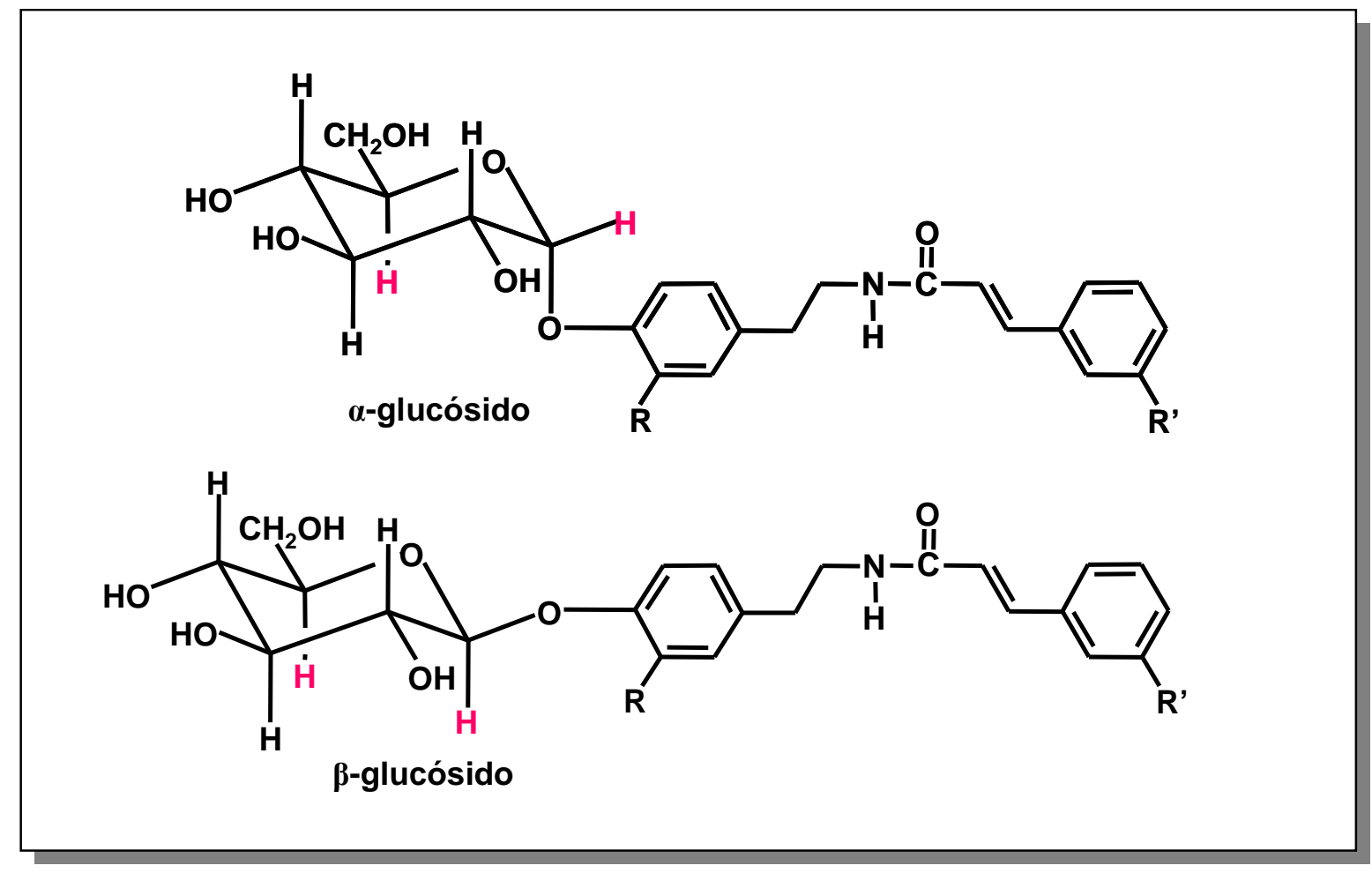

Figura 14. Conjugación de compuestos fenólicos en forma de $\alpha$ y $\beta$ glucósidos. 


\section{III.4.- Aislamiento y manipulación de ácidos nucleicos de plantas.}

\section{III.4.1. Transformación de Escherichia coli.}

La obtención de células competentes de Escherichia coli (DH5 $\alpha)$ se realizó con un tratamiento con metales divalentes y su transformación se llevó a cabo mediante un choque térmico a $42^{\circ} \mathrm{C}$, según el método descrito por Hanahan (1986) y modificado por Ausubel et al. (1995).

\section{III.4.2. Purificación de plásmidos bacterianos.}

La purificación de plásmidos de bajo número de copia $\left(\mathrm{pBI}^{\circledR}\right)$ y de alto número de copia (pBluescript ${ }^{\circledR}$ SK (+/-) y pGEM $^{\circledR} 7$ ) se realizó según los protocolos convencionales de lisis alcalina descritos por Ausubel et al. (1995), o según las instrucciones del fabricante del Kit 'High Pure Plasmad Isolation Kit' (Roche) en el caso de que las muestras fueran enviadas a secuenciar. Los clonajes y subclonajes de los fragmentos de DNA en estos plásmidos se realizaron mediante inserción en sitios de restricción concretos, según los métodos descritos por Ausubel et al. (1995) y Sambrook et al. (1989).

\section{III.4.3.- Aislamiento y manipulación de RNA de plantas.}

La extracción de RNA de diferentes tejidos de planta se llevó a cabo con Trizol ${ }^{\circledR}$ (Gibco BRL ${ }^{\circledR}$ Life Technologies) siguiendo las instrucciones del fabricante. Para los análisis de transcripción reversa se utilizaron $10 \mu \mathrm{g}$ de RNA total, cuantificado por $\mathrm{A}_{260}$.

\section{III.4.4.- Reacciones de amplificación (RT-PCR).}

Para las reacciones de transcripción reversa (RT) se partió de $10 \mu \mathrm{g}$ de RNA total para un volumen final de reacción de $50 \mu \mathrm{l}$, utilizando oligo(dT) $)_{18}$ como cebador para copiar selectivamente mRNAs y como transcriptasa reversa la M-MLV de Promega. En cada reacción de PCR se emplearon: $5 \mu$ de la reacción de RT, $1 \mu \mathrm{l}$ de cada cebador, $5 \mu \mathrm{l}$ de dNTPs $2.5 \mathrm{mM}, 5 \mu \mathrm{l}$ de tampón de reacción $10 \mathrm{X}$ y 2 unidades de 
DNA polimerasa (Netzyme NEED). Las condiciones de PCR fueron las siguientes: 1 min de desnaturalización a $94^{\circ} \mathrm{C}$, seguido de 25 ciclos de 1 min de desnaturalización a $94^{\circ} \mathrm{C}, 1$ min de anillamiento a $55^{\circ} \mathrm{C}$ y 1 min de extensión a $72^{\circ} \mathrm{C}$, terminando con un paso de extensión final de $5 \min$ a $72^{\circ} \mathrm{C}$.

Los cebadores específicos empleados para amplificar el gen hidroxicinamoilCoA:tiramina N-(hidroxicinamoil)transferasa (THT1-3) (Von Roepenack-Lahaye et al. 2003) fueron los siguientes: directo (5'-ATGGCTCCTGCTCTTGAACAAG-3') y reverso (5' -CTAACAGCTCCCTTTCGCCGT-3'). Los utilizados para amplificar el gen de la proteína ribosomal L2 (RPL2) (Fleming et al., 1993) fueron los siguientes: oligonucleótido directo (5'-GGTGACCGTGGTGTCTTTGC-3') y reverso (5'ACCAACCTTTTGTCCAGGAGGT-3').

\section{III.4.5. Secuenciación de DNA.}

Para la secuenciación de los diferentes clones se siguió el protocolo de los didesoxinucleótidos (terminadores) marcados con compuestos fluorescentes (Prober et al., 1987). Los productos marcados se resolvieron en un secuenciador ABI 377 (Applied Biosystems). Los datos proporcionados por el secuenciador se refinaron mediante el programa CHROMAS para la resolución de posibles indeterminaciones.

\section{III.4.6. Aplicaciones bioinformáticas.}

Los análisis de secuencia se realizaron empleando la aplicación MEGALIGN del la suite informática DNAstar de Lasergene. Para otras manipulaciones se emplearon diferentes programas instalados en máquinas locales. Se empleó el programa GENEDOC para realzar las zonas homólogas de los alineamientos.

Los rastreos mediante el algoritmo BLAST de las bases de datos EMBL/GenBank, se efectuaron a través de los formularios en línea que se encuentran en la dirección de Internet del National Center for Biotechnology Information (Bethesda, MD; http://www.ncbi.nlm.nih.gov). 


\section{III.5.- Técnicas de análisis, síntesis, cuantificación e identificación de metabolitos.}

\section{III.5.1.- Análisis y cuantificación de las muestras por cromatografía líquida de alta resolución (HPLC).}

Los análisis por HPLC de los extractos de hojas se hicieron siguiendo los protocolos ya descritos en Yalpani et al. (1993) y Bellés et al. (1999). De los $200 \mu \mathrm{l}$ del extracto metanólico final se inyectaron $40 \mu \mathrm{l}$ en una columna de fase reversa Symmetry C18 (5 $\mu \mathrm{m}, 4.6$ x 150 mm; Waters, Mildford, MA) equilibrada con ácido acético al 1\% (J.T. Baker). Se aplicó un gradiente de metanol (0 a 100\%) durante 20 min, con un flujo constante de $1 \mathrm{ml} / \mathrm{min}$, manteniendo la temperatura a $30^{\circ} \mathrm{C}$. Las HCAAs ( $p$ cumaroildopamina, feruloildopamina, $p$-cumaroiltiramina $y$ feruloiltiramina) se detectaron con un detector de absorbancia Waters 486, en la banda de $280 \mathrm{~nm}$, y se cuantificaron con el programa informático Millenium32 (Waters), utilizando HCAAs sintéticas como patrones.

\section{III.5.2.- Análisis de la producción de etileno mediante técnicas de cromatografía} gaseosa.

La medida de la producción de etileno se realizó introduciendo $0.5 \mathrm{~g}$ de cada muestra de tejido de hoja, en viales de vidrio de $18 \mathrm{ml}$, cerrados herméticamente durante $2 \mathrm{~h}$ a temperatura ambiente. Pasado este tiempo se tomo $1 \mathrm{ml}$ de muestra gaseosa y se inyectó en un cromatógrafo de gases Hewlett-Packard 4890 equipado con una columna TRB-1 TRACER (60 m de logitud, 0.56 mm I.D.) conectada a un detector de ionización de llama (FID). Las muestras quedaron registradas en un integrador Hewlett-Packard 3395. La temperatura del horno era de $60^{\circ} \mathrm{C}$. El pico de etileno quedó registrado a 0.98 min. La producción de etileno se calculó como la media de tres incubaciones independientes, y se utilizó una curva estándar de producción de etileno que relacionaba el área de pico con la cantidad de etileno producida (nl/g peso fresco). 


\section{III.5.3.- Identificación de metabolitos mediante cromatografía líquida de alta resolución y espectrometría de masas acoplada (HPLC-MS).}

La identificación de los cuatro compuestos mayoritarios detectados en extractos metanólicos de hojas infectadas con Pseudomonas syringae pv. tomato, se llevó a cabo utilizando espectrómetro de masas ZMD Micromass (Waters) de cuadrupolo equipado con un sistema de ionización por electro-spray (ESI-MS) directamente acoplado a un cromatógrafo HPLC Waters 1515 con un detector de matriz de fotodiodos (photodiode array detector, PAD) Waters 996 (rango entre 240 y 400 nm, resolución 1.2 nm). Los parámetros del espectrómetro de masas para la ionización por electro-spray positivo son los siguientes: voltaje capilar $2500 \mathrm{~V}$, voltaje de cono $20 \mathrm{~V}$, extractor $5 \mathrm{~V}$, RF Lens 0.5 $\mathrm{V}$, temperatura de bloque $100^{\circ} \mathrm{C}$ y temperatura de desolvatación $300^{\circ} \mathrm{C}$. El gas de desolvatación y de cono utilizado fue nitrógeno, con un flujo de 400 y 60 1/min, respectivamente. Otros parámetros del espectrómetro de masas son: resolución de masa mínima 13.5, resolución de masa máxima 13.5, energía de ionización 0.5 , multiplicador 650. Los datos del ratio masa/carga (m/z) se dan en un rango de 100 a 700 a 1 s por scan.

De los $200 \mu \mathrm{l}$ del extracto metanólico final se inyectaron $20 \mu \mathrm{l}$ en una columna de fase reversa Symmetry C18 (5 $\mu \mathrm{m}, 4.6$ x $150 \mathrm{~mm}$; Waters, Mildford, MA) equilibrada con ácido acético al 1\% (J.T. Baker). Se aplicó un gradiente de metanol (0 a $100 \%$ ) durante $20 \mathrm{~min}$, con un flujo constante de $1 \mathrm{ml} / \mathrm{min}$, manteniendo la temperatura a $30^{\circ} \mathrm{C}$. A la salida de la columna, aproximadamente en $25 \%$ del flujo se derivó al espectómetro de masas y el resto al PDA Waters 996. Los espectros de masas y de absorción al ultravioleta de los metabolitos objeto de estudio, así como de los sintéticos, se obtuvieron mediante el programa informático Masslynx (Waters).

\section{III.5.4- Síntesis de las HCAAs.}

Las HCAAs estudiadas se sintetizaron químicamente en el laboratorio mediante la reacción de los ácidos $p$-cumárico y ferúlico, con tiramina y dopamina (forma hidroclórica), en presencia del catalizador $N, N^{\prime}$-diciclohexilcarbodiimida (DCC), tal y como se describe de forma detallada en Tanaka et al. (1989). Se mezclaron $0.5 \mathrm{nmol}$ del correspondiente ácido y $0.65 \mathrm{nmol}$ de la correspondiente amina, en $20 \mathrm{ml}$ de 
tetrahidrofurano (THF). A continuación se añadió una solución del catalizador DCC (0.8 nmol / $5 \mathrm{ml}$ de THF). La reacción se dejó toda la noche a temperatura ambiente. Después de eliminar los disolventes, la reacción se solubilizó en agua y se realizó una extracción líquido-líquido con acetato de etilo. La fase orgánica se secó con $\mathrm{Na}_{2} \mathrm{SO}_{4}$ anhidro y se evaporó hasta la obtención de un aceite viscoso. Dicho aceite se purificó hasta el aislamiento de la correspondiente amida, mediante una columna de silicagel flash 60 (Merck, 0.040-0.063 mm), utilizando como fase móvil una mezcla de diclorometano / acetato de etilo (1:1).

En la figura 15 se muestra el mecanismo de reacción correspondiente a la síntesis química de los metabolitos objeto de estudio.

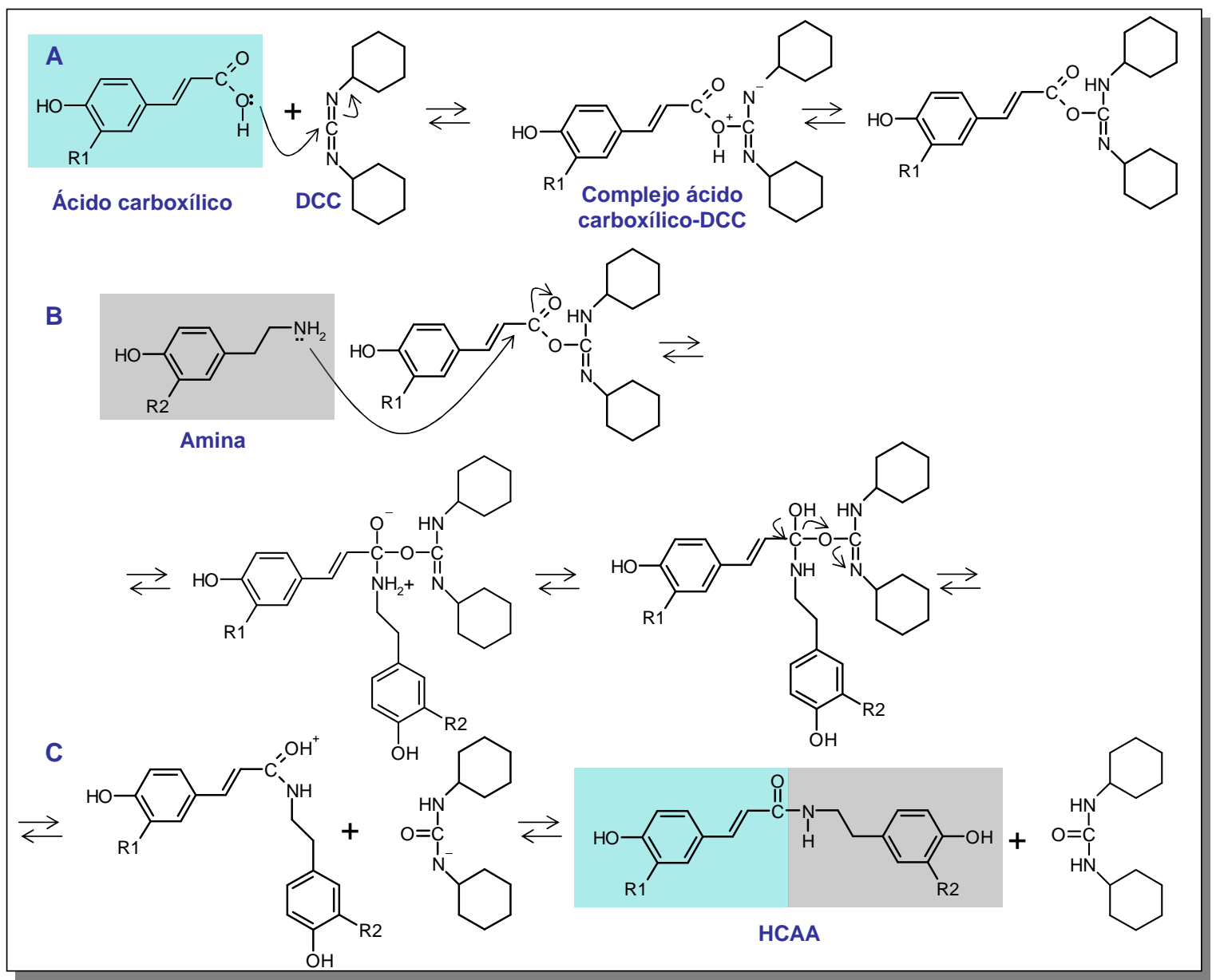

Figura 15. Mecanismo de reacción de la síntesis química de las HCAAs. Se distinguen tres fases en la reacción: Fase $\mathbf{A}$, adición del ácido carboxílico $\left(\mathrm{R} 1=\mathrm{H}\right.$, ácido cumárico; $\mathrm{R} 1=\mathrm{OCH}_{3}$, ácido ferúlico) al átomo de carbono de la diciclohexilcarbodiimida (DCC); Fase B, ataque nucleofílico de la amina (R2=H, tiramina; R2=OH, dopamina) al complejo ácido carboxílico-DCC; Fase C, formación de la HCAA (R1=H R2=OH, $p$-cumaroildopamina; $\mathrm{R} 1=\mathrm{OCH}_{3} \mathrm{R} 2=\mathrm{OH}$, feruloildopamina; $\mathrm{R} 1=\mathrm{H}$ R2=H, $p$ cumaroiltiramina; $\mathrm{R} 1=\mathrm{OCH}_{3} \mathrm{R} 2=\mathrm{H}$, feruloiltiramina) y liberación del catalizador en forma de urea. 


\section{III.5.5. Elaboración de curvas patrón de las HCAAs para su cuantificación.}

Se elaboró una curva patrón de cada uno de los metabolitos identificados en el presente trabajo con la finalidad de cuantificar los niveles alcanzados en la planta. Para ello, se inyectaron en el HPLC distintas cantidades conocidas de cada una de las amidas sintéticas y se calculó el área de pico observado en cada caso. En la figura 16 se muestran las curvas patrón elaboradas para cada una de las HCAAs: en abscisas se representan las distintas cantidades (nmoles) del compuesto ensayado y en ordenadas el área (unidades de área, u.a.) del pico en el cromatograma correspondiente. De esta forma se obtiene una ecuación que permite relacionar área de pico con nmoles. Utilizando dichas ecuaciones, podemos cuantificar la acumulación de las HCAAs en plantas de tomate a lo largo de la infección con Pseudomonas syringae.

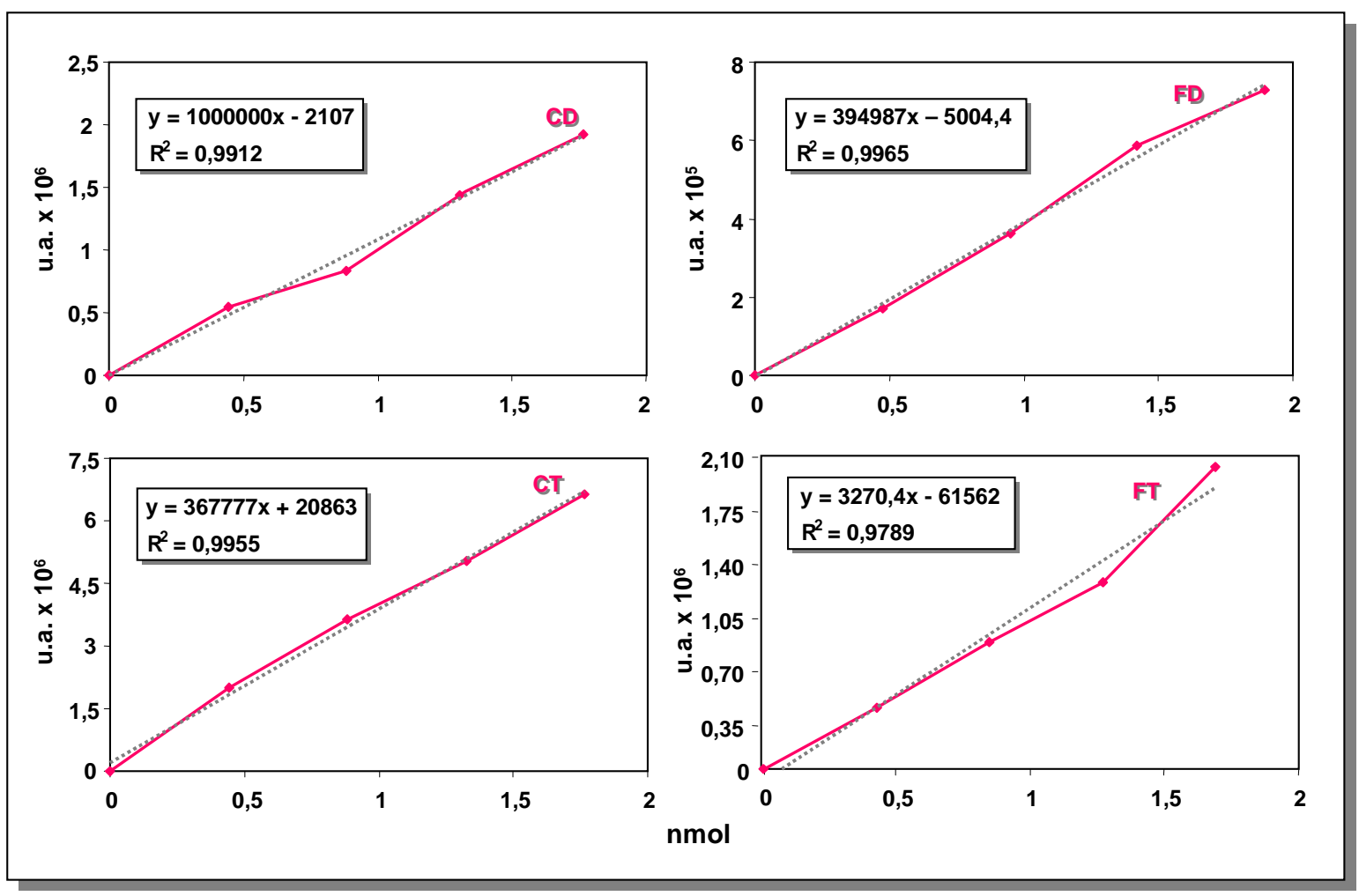

Figura 16. Curvas patrón para cada una de las HCAA. 


\section{III.6.- Ensayo de actividades in vitro de las HCAAs.}

\section{III.6.1.- Ensayo de la actividad antibacteriana in vitro.}

El test de actividad antibacteriana se llevó a cabo siguiendo el método descrito por Cole (1994). La bacteria Pseudomonas syringae pv. tomato almacenada a $-80^{\circ} \mathrm{C}$ en glicerol al 80\%, fue reactivada en placas Petri de $20 \mathrm{ml}$ que contenían medio KB (por cada $1000 \mathrm{ml}$ de medio KB: $40 \mathrm{~g}$ de proteosa peptona, $20 \mathrm{~g}$ de glicerol, $980 \mathrm{ml}$ de agua, $10 \mathrm{ml}$ de $\mathrm{K}_{2} \mathrm{HPO}_{4}$ al $10 \%$, y $10 \mathrm{ml}$ de $\mathrm{MgSO}_{4}$ al $10 \%$ ). Después de incubar las placas durante $48 \mathrm{~h}$ a $28^{\circ} \mathrm{C}$, se recogió una colonia aislada y se sembró en $15 \mathrm{ml}$ de medio LB líquido (Pronadisa), dejándose en agitación a $220 \mathrm{rpm}$ y a $28^{\circ} \mathrm{C}$ durante una noche. A continuación, se mezcló $1 \mathrm{ml}$ del caldo de cultivo bacteriano con $15 \mathrm{ml}$ de Plate Count Agar (Difco) en una placa Petri. Cuando el medio estuvo completamente solidificado, se colocaron, en cada placa, tres discos de papel Whatman $\left(\mathrm{n}^{\circ} 13,0.5 \mathrm{~mm}\right.$ de diámetro) impregnados con diferentes concentraciones de cada HCAA disuelta en $10 \mu \mathrm{l}$ de metanol. Como control negativo del experimento se utilizaron placas preparadas tal y como se ha descrito anteriormente, donde se colocaron discos únicamente impregnados con metanol. Como control positivo se utilizó el antibiótico de amplio espectro tetraciclina a una concentración de $10 \mu \mathrm{g} / \mathrm{cm}^{2}$. La actividad antibacteriana se determinó midiendo el halo de inhibición de crecimiento bacteriano alrededor del disco de papel y determinando la Concentración Mínima Inhibitoria (MIC) para cada amida. Cada ensayo se realizó por triplicado.

\section{III.6.2.- Ensayo de la actividad antioxidante in vitro.}

La actividad antioxidante de los ácidos p-cumárico y ferúlico, de la tiramina, de la dopamina y de las HCAA, fue evaluada mediante el ensayo basado en la inactivación del radical libre estable 2,2-difenil-1-picrilhidracil (DPPH) (Hirota et al., 2000), tal y como se describe en Alfaro et al. (2003). Se mezclaron 2 ml de una disolución etanólica del compuesto ensayado a diferentes concentraciones, con $1 \mathrm{ml}$ de una disolución de DPPH $0.5 \mathrm{mM}$ (disuelto en etanol) y $2 \mathrm{ml}$ de acetato sódico $0.1 \mathrm{M}$ (pH 5.5). Después de mantener la mezcla a $25^{\circ} \mathrm{C}$ durante $30 \mathrm{~min}$, se realizó una medida de la absorbancia a $517 \mathrm{~nm}$ en un espectrofotómetro JENWAY 6305. La capacidad de inactivación del radical libre DPHH por parte de cada producto ensayado, se expresó como la 
concentración de producto necesaria para reducir al 50\% la absorbancia del DPPH a 517 $\mathrm{nm}\left(\mathrm{ED}_{50}\right)$. Como control positivo se utilizó hidroxitolueno butilado (BHT). Los datos obtenidos representan la media de tres experimentos independientes.

\section{III.7. Obtención de plantas transgénicas.}

\section{III.7.1. Obtención del cDNA del gen THT1-3 de tomate.}

El cDNA correspondiente al gen hidroxicinamoil-CoA:tiramina N(hidroxicinamoil)transferasa de tomate (THT1-3) (Von Roepenack-Lahaye et al. 2003), se obtuvo mediante RT-PCR de plantas de tomate infectadas con la bacteria Pseudomonas syringae pv. tomato, utilizando como cebadores específicos los siguientes:

\begin{tabular}{lccr}
\hline $\begin{array}{c}\text { Nombre del } \\
\text { cebador }\end{array}$ & Secuencia 5'-3, & Sitio de corte & Hebra \\
\hline THT1-3 Dir & CCGGATCCTCTAGAATGGCTCCTGCTCTTGAACA & Bam HI, Xba I & Directa \\
\hline THT1-3 Rev & CCGGATCCCTAACAGCTCCCTTTCGCCGT & Bam HI & Reversa \\
\hline
\end{tabular}

El producto de PCR obtenido fue clonado en el vector pGEM-T easy y secuenciado, obteniendo así el plásmido denominado pGEM-THT.

\section{III.7.2. Fusión de la región directa del gen THT1-3 al promotor doble del CaMV35S.}

La fusión de la pauta abierta de lectura del gen THT1-3 al promotor doble $35 \mathrm{~S}$ del Virus del Mosaico de la Coliflor se llevó a cabo en dos etapas. En la primera de ellas, se llevó a cabo la ligación de la banda correspondiente al cDNA, obtenida por digestión del plásmido $p G E M-T H T$ con el enzima de restricción Bam $\mathrm{HI}$, a un vector pBlue-2X-modificado (pBluescript con una región doble del promotor del CaMV35S), digerido con Bam HI. La comprobación de que el cDNA se había insertado en sentido (+) se realizó mediante digestión con los enzimas Eco RI - Xba I obteniéndose una 
banda de 361 pb (banda Eco RI - Xba I del cDNA) y otra de 630 pb (banda Eco RI Eco RI del 2XCaMV35S). En una segunda etapa, se liberó el cassette [2XCaMV35S :: THT sentido (+) $\because$ terminador del gen nos] con el enzima Hind III y se insertó en el vector pBI121, obteniendo así la construcción denominada pBI::gus::35S2X::THT::nos. Este vector presenta el gen marcador GUS ( $\beta$-glucuronidasa) bajo el control transcripcional del promotor constitutivo CaMV35S (Esquema 2).

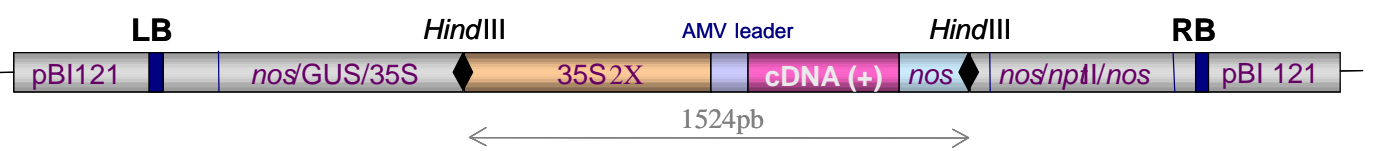

Esquema 2. Construcción pBI121::GUS::35S2X::cDNA::nos. El promotor 35S que dirige la expresión de la proteína GUS se encuentra en el sentido inverso al promotor doble 35S2X que dirige la expresión de la pauta de lectura abierta del gen THT1-3. Se señala la longitud del cassette Hind III. LB: borde izquierdo del plásmido binario; RB: borde derecho del plásmido binario.

\section{III.7.3. Transformación de Agrobacterium tumefaciens.}

La transformación de células competentes de Agrobacterium tumefaciens de la cepa C58, utilizada para transformar Arabidopsis thaliana, así como la de la cepa LBA4404, utilizada para transformar tomate, se llevó a cabo mediante choque térmico, siguiendo el método descrito por Bevan (1984).

\section{III.7.4. Transformación genética de plantas de Arabidopsis thaliana.}

La construcción correspondiente al apartado III.7.1 fue introducida en la cepa de Agrobacterium tumefaciens C58. La transformación genética de Arabidopsis thaliana con estas construcciones se llevó a cabo siguiendo el método descrito por Bechtold et al. (1993), mediante el cual se sumergen las flores y botones florales en una suspensión de Agrobacterium tumefaciens y se realiza una infiltración a vacío. Las semillas obtenidas a partir de dichas flores, se siembran en medio Murashige y Skoog con 50 $\mathrm{mg} / \mathrm{l}$ de kanamicina, que permite la selección de los transformantes por su resistencia a este antibiótico. 


\section{III.7.5. Transformación genética de plantas de tomate.}

La transformación genética de tomate var. 'UC82' con la construcción pBI::gus::35S2X::cDNA::nos se llevó a cabo mediante cocultivo de explantes de cotiledones en Agrobacterium tumefaciens LBA4404, según el método desarrollado por Ellul et al. (2003).

\section{III.7.6. Estudios in situ de la actividad $\beta$-glucuronidasa.}

Para los estudios de detección in situ de la actividad $\beta$-glucuronidasa, los tejidos frescos fueron infiltrados a vacío durante 25 minutos en una solución conteniendo 0.5 mg de X-Gluc (5-bromo-4-cloro-3-indolil glucurónido) y 0.1\% de Tritón X-100 en tampón fosfato $50 \mathrm{mM}$ a pH 7.2, e incubados a $37^{\circ} \mathrm{C}$ de 10 a 16 horas. A continuación se destiñeron con sucesivos lavados de etanol al $70 \%$. 
IV. Resultados y Discusión 


\section{Resultados y discusión.}

\section{IV.1.- Caracterización de cuatro amidas derivadas del ácido hidroxicinámico en tomate 'Rutgers' infectado con Pseudomonas syringae pv. tomato.}

\section{IV.1.1- La infección de plantas de tomate 'Rutgers' con la bacteria Pseudomonas syringae pv. tomato induce la acumulación de cuatro compuestos de naturaleza fenólica.}

La inoculación de hojas de tomate 'Rutgers' con la bacteria Ps. syringae pv. tomato a una concentración de $10^{7}$ unidades formadoras de colonias por mililitro (ufc/ml), produce una reacción necrotizante que puede considerarse como una respuesta hipersensible (HR-like). La infección se caracteriza por la aparición de unas manchas necróticas en las hojas, coincidentes con la zona inoculada. La necrotización del tejido foliar se produce de forma gradual y comienza a observarse cuando la zona inoculada toma un aspecto brillante a partir de las 17 horas post inoculación (hpi), culminando a las 72 hpi, momento en el cual las manchas necróticas han alcanzado un tamaño de aproximadamente $6 \mathrm{~mm}$ de diámetro y se ha producido un colapso celular total en toda la región inoculada (figura 17 A). Asimismo, aproximadamente a las 24 hpi, se observa una marcada epinastia en las hojas inoculadas, debido a la acumulación de la hormona etileno, como consecuencia de la infección bacteriana (figura 17 B).

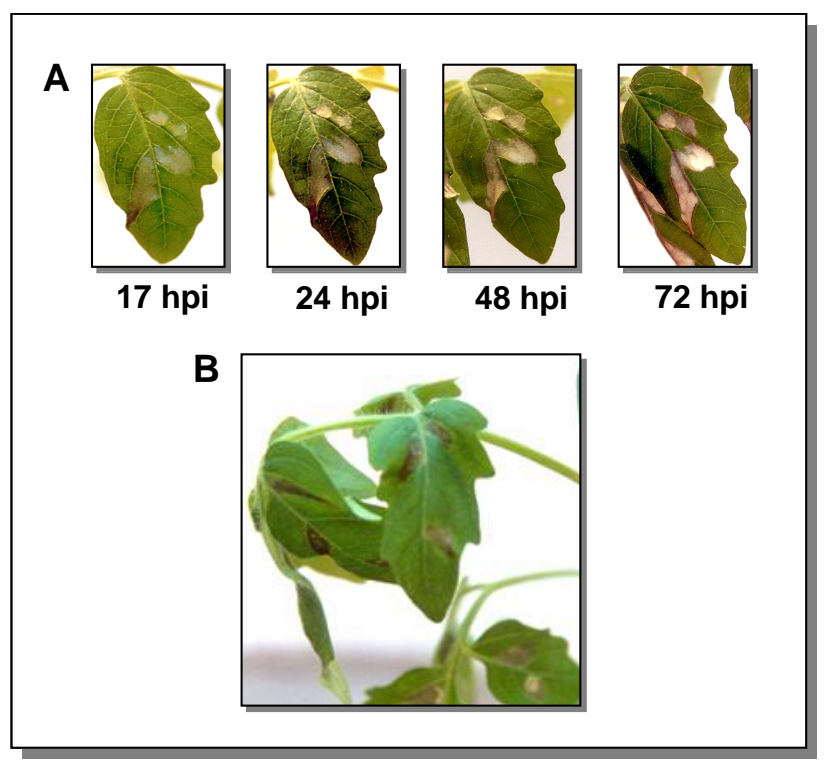

Figura 17. Plantas de tomate 'Rutgers' infectadas con la bacteria Pseudomonas syringae pv. tomato. (A) Evolución de los síntomas en las hojas inoculadas: la necrotización del tejido foliar se produce de forma gradual, hasta alcanzar un máximo a las 72 hpi. (B) Efecto del etileno producido durante la infección: a las 24 hpi se observa una marcada epinastia en las hojas inoculadas. 
En experimentos previos realizados en nuestro laboratorio, encontramos que en hojas de tomate 'Rutgers' infectadas con la bacteria Ps. syringae pv. tomato se produce la acumulación de ácido salicílico (SA) (Bellés et al., 1999), un compuesto fenólico fluorescente mediador de la respuesta hipersensible de las plantas frente a patógenos (Métraux y Raskin, 1993; Dempsey et al., 1999). Con el objetivo de encontrar otros metabolitos inducidos por Ps. syringae en tomate, decidimos llevar a cabo un análisis más general de compuestos que absorbieran en el UV, presentes en los extractos metanólicos de las hojas infectadas con la bacteria. La figura 18 muestra cromatogramas representativos de los compuestos fenólicos obtenidos de muestras de hojas infectadas tomadas a las 24 hpi y de hojas control (inoculadas únicamente con $\mathrm{MgSO}_{4} 10 \mathrm{mM}$ (ver apartado de Materiales y Métodos). Después de estudiar los espectros de absorción al UV mediante un detector de matriz de fotodiodos (PDA) en un rango de 240 a $400 \mathrm{~nm}$, se seleccionó una longitud de onda de $280 \mathrm{~nm}$ con el fin de analizar la acumulación de compuestos pertenecientes a la ruta de los fenilpropanoides. En los extractos de hojas infectadas se detecta la acumulación de cuatro compuestos mayoritarios, numerados por orden de aparición en el cromatograma (1, 2, 3 y 4), con tiempos de retención de 12.5, 12.7, 13.2 y $13.6 \mathrm{~min}$, respectivamente. Como puede observarse en dicha figura, existe un pico adicional con tiempo de retención ligeramente inferior al del compuesto 3 (compuesto 2'), de que hablaremos más adelante. Dichos compuestos no están presentes en los extractos correspondientes a hojas control (figura 18). 


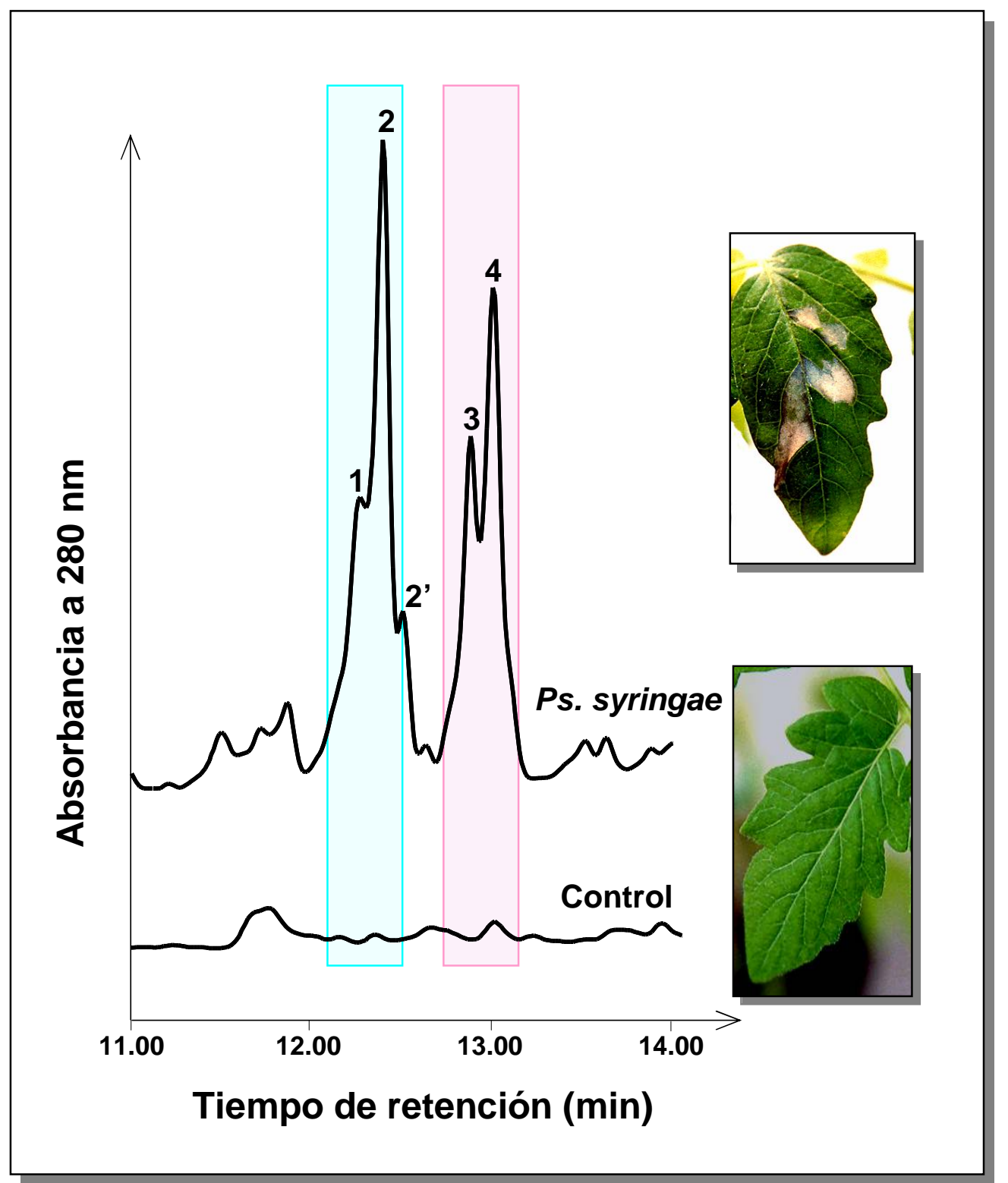

Figura 18. Análisis por HPLC de los extractos metanólicos de hojas de tomate 'Rutgers'. Las plantas fueron inoculadas con la bacteria Pseudomonas syringae pv. tomato a una concentración de $10^{7} \mathrm{ufc} / \mathrm{ml}$. Se recogieron muestras a las 24 hpi y se realizó una extracción de compuestos fenólicos. Los extractos se analizaron por HPLC y la detección se realizó a $280 \mathrm{~nm}$. Los picos 1, 2, 2', 3 y 4 representan los compuestos fenólicos acumulados en las hojas infectadas.. Dichos compuestos no se detectan en los correspondientes controles. 
IV.1.2.- Estudio de los espectros de masas y de absorbancia de los compuestos 1, 2, 3 y 4 inducidos por la infección de Pseudomonas syringae pv. tomato.

Con el fin de identificar de forma precisa los compuestos correspondientes a los picos 1, 2, 3 y 4, los extractos metanólicos de hojas de tomate infectadas se analizaron mediante técnicas de cromatografía líquida de alta resolución acoplada a espectometría de masas (HPLC-MS) combinadas con técnicas de ionización por electro-spray (ESI). A continuación se explica de forma detallada la identificación de cada uno de los compuestos aislados.

Identificación del compuesto 1.

El espectro de masas obtenido mediante la técnica de ionización por electrospray presenta un pico molecular $\mathrm{m} / \mathrm{z} 300\left[\mathrm{M}+\mathrm{H}^{+}\right]$que se corresponde con la fórmula molecular $\mathrm{C}_{17} \mathrm{H}_{17} \mathrm{O}_{4} \mathrm{~N}$ (figura $19 \mathrm{~A}$ ). La molécula genera además un fragmento de masa molecular 147, que es coherente con la fórmula $\left(\mathrm{C}_{9} \mathrm{H}_{7} \mathrm{O}_{2}{ }^{-}\right)$(figura XA). Dicho fragmento es característico de metabolitos que poseen en su molécula una parte derivada del ácido cumárico (Yoshihara et al., 1978). La parte restante de la molécula $\left(\mathrm{C}_{8} \mathrm{H}_{10} \mathrm{O}_{2} \mathrm{~N}^{+}\right)$contiene un grupo hidroxilo más que la tiramina (ver compuestos $3 \mathrm{y} 4$ ), pudiendo corresponder a la fórmula molecular de la octopamina, en el caso de que el grupo hidroxilo se encuentre unido al carbono 7, o bien a la fórmula molecular de la dopamina, en el caso de que el grupo hidroxilo se encuentre unido al anillo bencénico. Las HCAAs que poseen octopamina en su molécula generan un fragmento característico de la presencia del grupo hidroxilo en posición 7 de masa molecular $\left[\mathrm{M}+\mathrm{H}-\mathrm{H}_{2} \mathrm{O}\right]$, y por tanto, deberíamos observar, en el espectro de masas del compuesto 1, un pico de 282 unidades de masa. Basándonos en la ausencia de este pico, hemos llegado a la conclusión de que nos encontramos ante una molécula cuya estructura está formada por una parte que proviene del ácido cumárico y otra que proviene de la dopamina. La estructura propuesta es por tanto la de la $p$-cumaroildopamina (CD). En el espectro de masas se observa además la aparición de un pico molecular m/z de $599[2 \mathrm{M}+\mathrm{H}]^{+}$que correspondería a un dímero de CD formado como consecuencia del método de ionización empleado. El espectro de absorción en el UV del compuesto 1 presenta dos máximos relativos $(\lambda=290,306 \mathrm{~nm})$, indicando la presencia de dos grupos fenólicos distintos. Los espectros de UV y masas presentados en la figura 19 A son idénticos a los 
obtenidos para la CD sintetizada en el laboratorio (figura 19 B). Además, ambas coeluyen a un tiempo de retención de $12.5 \mathrm{~min}$.

Identificación del compuesto 2.

El espectro de masas obtenido mediante la técnica de ionización por electrospray presenta un pico molecular $\mathrm{m} / \mathrm{z} 330\left[\mathrm{M}+\mathrm{H}^{+}\right]$que se corresponde con la fórmula molecular $\mathrm{C}_{18} \mathrm{H}_{19} \mathrm{O}_{5} \mathrm{~N}$ (figura $20 \mathrm{~A}$ ). La molécula genera, además, un fragmento de masa molecular 177, que es coherente con la fórmula $\left(\mathrm{C}_{10} \mathrm{H}_{9} \mathrm{O}_{3}{ }^{-}\right)$(figura $20 \mathrm{~A}$ ). Dicho fragmento es característico de metabolitos que poseen una parte en su molécula derivada del ácido ferúlico (Yoshihara et al., 1978). La parte restante de la molécula $\left(\mathrm{C}_{8} \mathrm{H}_{10} \mathrm{O}_{2} \mathrm{~N}^{+}\right)$contiene, nuevamente, un grupo hidroxilo más que la tiramina (ver compuestos 3 y 4). Como ya hemos visto, dicha fórmula molecular puede corresponder a la octopamina, en el caso en que el grupo hidroxilo se encuentre unido al carbono 7, o a la dopamina en el caso en que el grupo hidroxilo se encuentre unido al anillo bencénico. Las HCAAs que poseen octopamina en su molécula generan un fragmento, característico de la presencia del grupo hidroxilo en posición 7, de masa molecular $\left[\mathrm{M}+\mathrm{H}-\mathrm{H}_{2} \mathrm{O}\right]$, y por tanto, en este caso, deberíamos observar en el espectro de masas del compuesto 2 un pico de 312 unidades de masa. Basándonos en la ausencia de este pico, hemos llegado a la conclusión de que nos encontramos ante una molécula cuya estructura está formada por una parte que proviene del ácido ferúlico y otra, que proviene de la dopamina. La estructura propuesta es, por tanto, la de la feruloildopamina (FD). En el espectro de masas se observa, además, la aparición de un pico molecular $\mathrm{m} / \mathrm{z}$ de $659[2 \mathrm{M}+\mathrm{H}]^{+}$que correspondería a un dímero de $\mathrm{FD}$ formado como consecuencia del método de ionización empleado. El espectro de absorción en el UV del compuesto 2 es similar al del compuesto 1, presentando nuevamente dos máximos relativos a 290 y $318 \mathrm{~nm}$, que indican la presencia de dos grupos fenólicos distintos. Los espectros de UV y masas presentados en la figura 20 A son idénticos a los obtenidos para la FD sintetizada en el laboratorio (figura 20 B). Además, ambas coeluyen a un tiempo de retención de $12.5 \mathrm{~min}$. 
Identificación del compuesto 3.

El espectro de masas obtenido mediante la técnica de ionización por electrospray presenta un pico molecular m/z $284\left[\mathrm{M}+\mathrm{H}^{+}\right]$que se corresponde con la fórmula molecular $\mathrm{C}_{17} \mathrm{H}_{17} \mathrm{O}_{3} \mathrm{~N}$ (figura $21 \mathrm{~A}$ ). La molécula genera, además, un fragmento de masa molecular 147, que es coherente con la fórmula $\left(\mathrm{C}_{9} \mathrm{H}_{7} \mathrm{O}_{2}{ }^{-}\right)$(figura $21 \mathrm{~A}$ ). Como se ha comentado para el caso del compuesto 1, dicho fragmento es característico de metabolitos que poseen una parte en su molécula derivada del ácido cumárico (Yoshihara et al., 1978). La parte restante de la molécula $\left(\mathrm{C}_{8} \mathrm{H}_{10} \mathrm{ON}^{+}\right)$corresponde a la fórmula molecular de la tiramina. El espectro de absorción en el UV presenta dos máximos relativos a 291 y $306 \mathrm{~nm}$, indicando la presencia de dos grupos fenólicos distintos. Por tanto, nos encontramos ante una amida derivada del ácido hidroxicinámico (HCAA), una molécula de naturaleza fenólica, cuya estructura está formada por una parte que proviene del ácido cumárico y otra parte derivada de la tiramina. La estructura propuesta es por tanto la de la p-cumaroiltiramina (CT) (Keller et al., 1996; Pearce et al., 1998; von Roepenack-Lahaye et al., 2003). En el espectro de masas se observa además la aparición de un pico molecular m/z de $567[2 \mathrm{M}+\mathrm{H}]^{+}$que correspondería a un dímero de CT formado como consecuencia del método de ionización empleado. Los espectros de UV y masas presentados en la figura 21 A son idénticos a los obtenidos para la CT sintetizada en el laboratorio (figura 21 B). Además, ambos coeluyen a un tiempo de retención de $13.2 \mathrm{~min}$.

\section{Identificación del compuesto 4.}

El espectro de masas obtenido mediante la técnica de ionización por electrospray presenta un pico molecular $\mathrm{m} / \mathrm{z} 314\left[\mathrm{M}+\mathrm{H}^{+}\right]$que se corresponde con la fórmula molecular $\mathrm{C}_{18} \mathrm{H}_{19} \mathrm{O}_{4} \mathrm{~N}$ (figura $22 \mathrm{~A}$ ). La molécula genera, además, un fragmento de masa molecular 177, que es coherente con la fórmula $\left(\mathrm{C}_{10} \mathrm{H}_{9} \mathrm{O}_{3}{ }^{-}\right)$(figura $22 \mathrm{~A}$ ). Como se ha comentado para el caso del compuesto 2, dicho fragmento es característico de metabolitos que poseen una parte en su molécula derivada del ácido ferúlico (Yoshihara et al., 1978). La parte restante de la molécula $\left(\mathrm{C}_{8} \mathrm{H}_{10} \mathrm{ON}^{+}\right)$corresponde a la fórmula molecular de la tiramina. El espectro de absorción en el UV presenta dos máximos relativos a 292 y $318 \mathrm{~nm}$, indicando la presencia de dos grupos fenólicos distintos. Por tanto, nos encontramos de nuevo ante una amida derivada del ácido hidroxicinámico 
(HCAA), una molécula de naturaleza fenólica, cuya estructura está formada en este caso por una parte que proviene del ácido ferúlico y otra parte derivada de la tiramina. La estructura propuesta es, por tanto, la de la feruloiltiramina (FT) (Keller et al., 1996; Negrel et al., 1996; Pearce et al., 1998). En el espectro de masas se observa, además, la aparición de un pico molecular $\mathrm{m} / \mathrm{z}$ de $627[2 \mathrm{M}+\mathrm{H}]^{+}$que correspondería a un dímero de FT formado como consecuencia del método de ionización empleado. Los espectros de UV y masas presentados en la figura 22 A son idénticos a los obtenidos para la FT sintetizada en el laboratorio (figura 22 B). Además, ambas coeluyen a un tiempo de retención de $13.5 \mathrm{~min}$. 


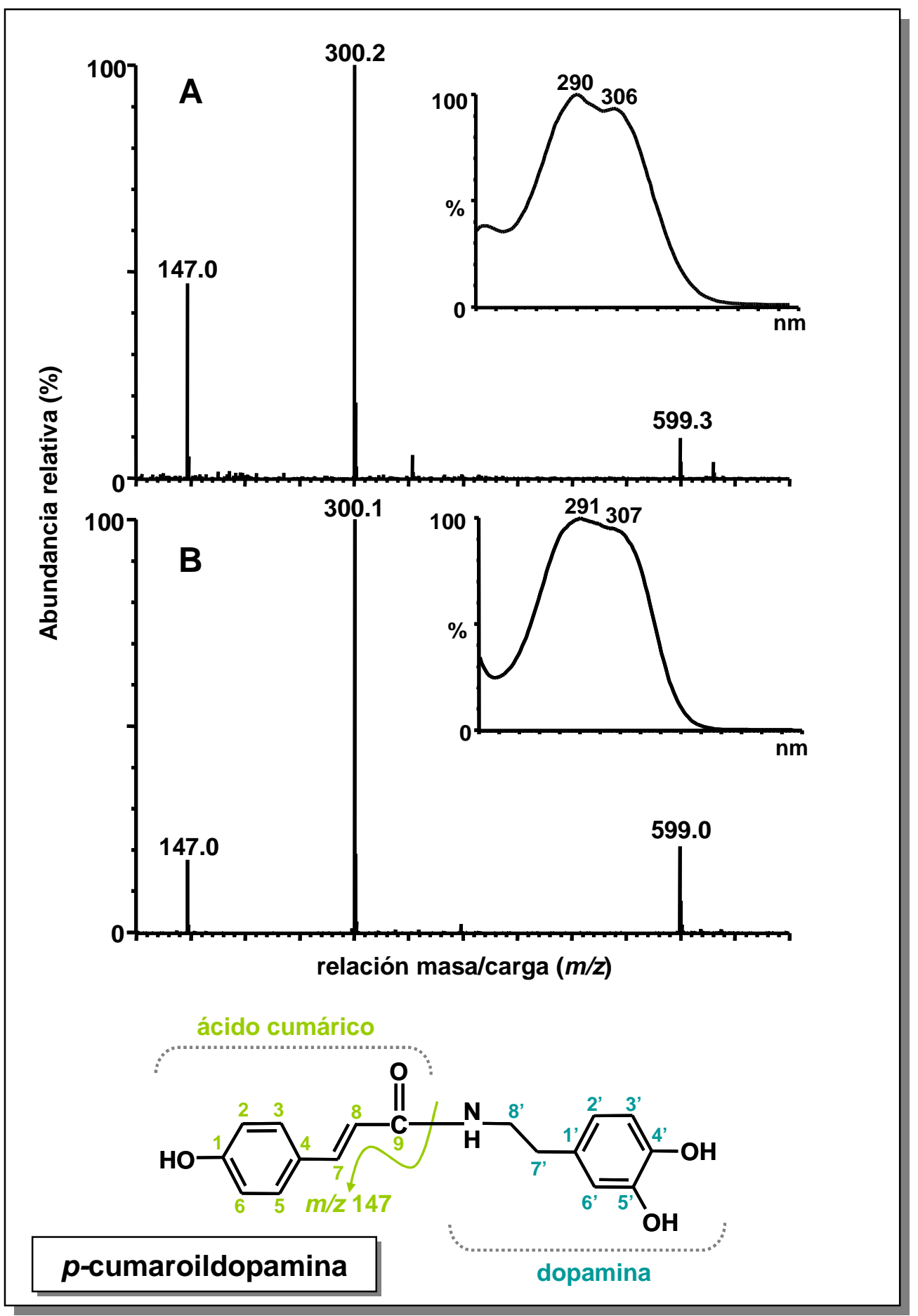

Figura 19. Espectros de masas y de absorción en el UV relativos al compuesto 1. (A) Espectro de masas obtenido mediante la técnica de ionización por electro-spray y espectro de absorción al UV del compuesto 1 detectado en extractos metanólicos de hojas de tomate 'Rutgers' infectadas con Pseudomonas syringae pv. tomato. (B) Espectro de masas obtenido mediante la técnica de ionización por electro-spray y espectro de absorción al UV de la $p$ cumaroildopamina sintetizada en el laboratorio. 


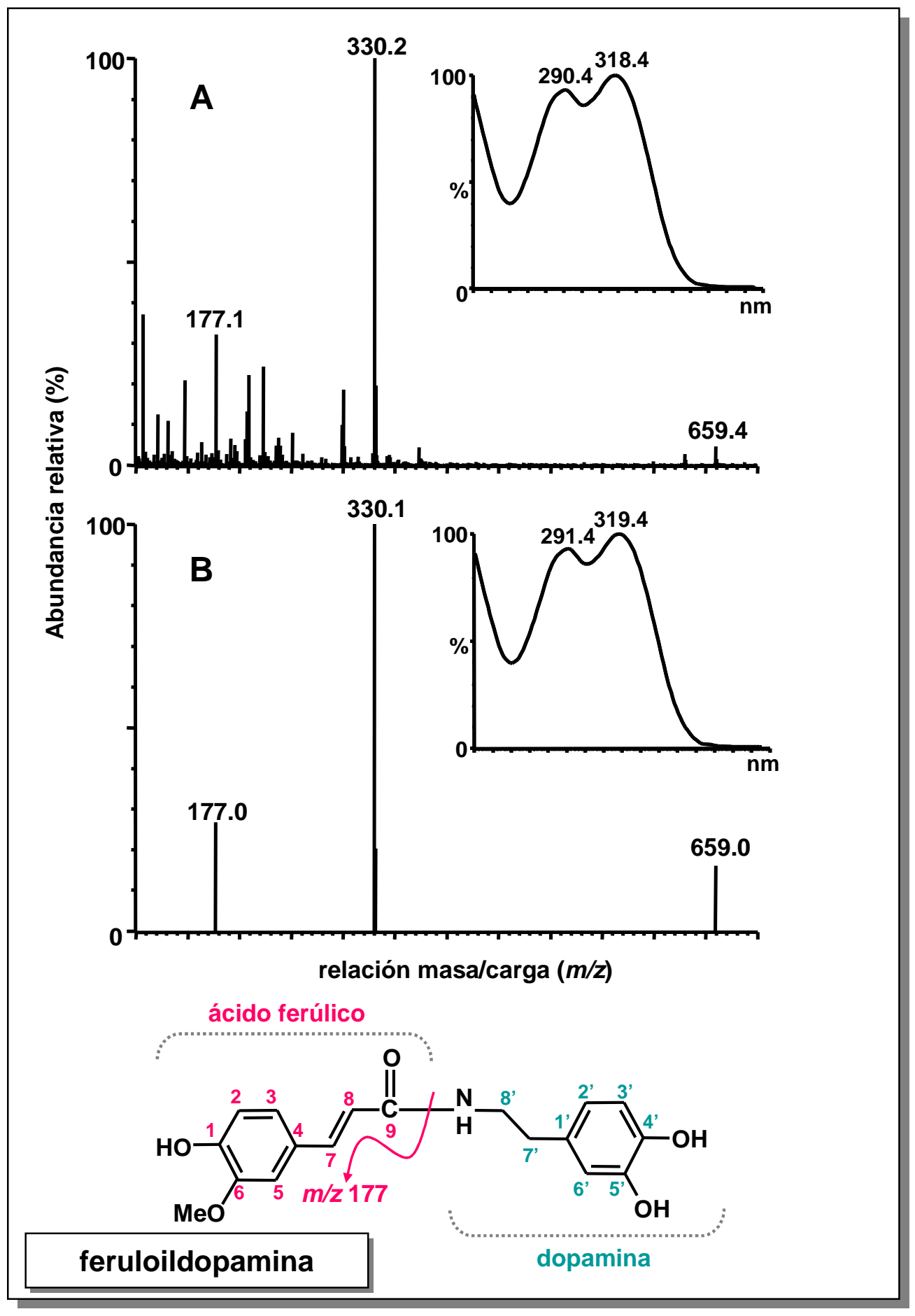

Figura 20. Espectros de masas y de absorción en el UV relativos al compuesto 2. (A) Espectro de masas obtenido mediante la técnica de ionización por electro-spray y espectro de absorción al UV del compuesto 2 detectado en extractos metanólicos de hojas de tomate 'Rutgers' infectadas con Pseudomonas syringae pv. tomato. (B) Espectro de masas obtenido mediante la técnica de ionización por electro-spray y espectro de absorción al UV de la feruloildopamina sintetizada en el laboratorio. 


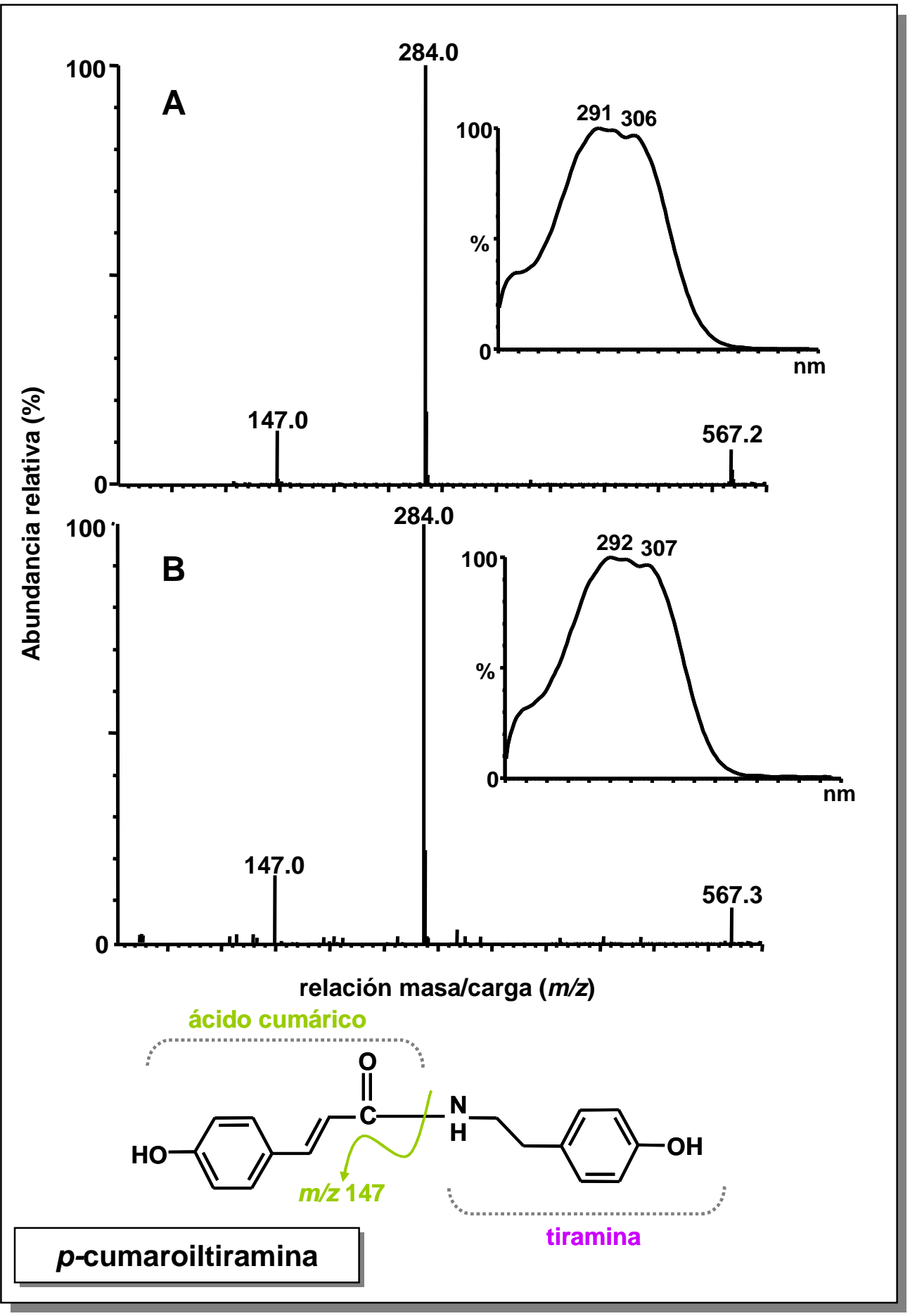

Figura 21. Espectros de masas y de absorción en el UV relativos al compuesto 3. (A) Espectro de masas obtenido mediante la técnica de ionización por electro-spray y espectro de absorción al UV del compuesto 3 detectado en extractos metanólicos de hojas de tomate 'Rutgers' infectadas con Pseudomonas syringae pv. tomato. (B) Espectro de masas obtenido mediante la técnica de ionización por electro-spray y espectro de absorción al UV de la $p$ cumaroiltiramina sintetizada en el laboratorio. 


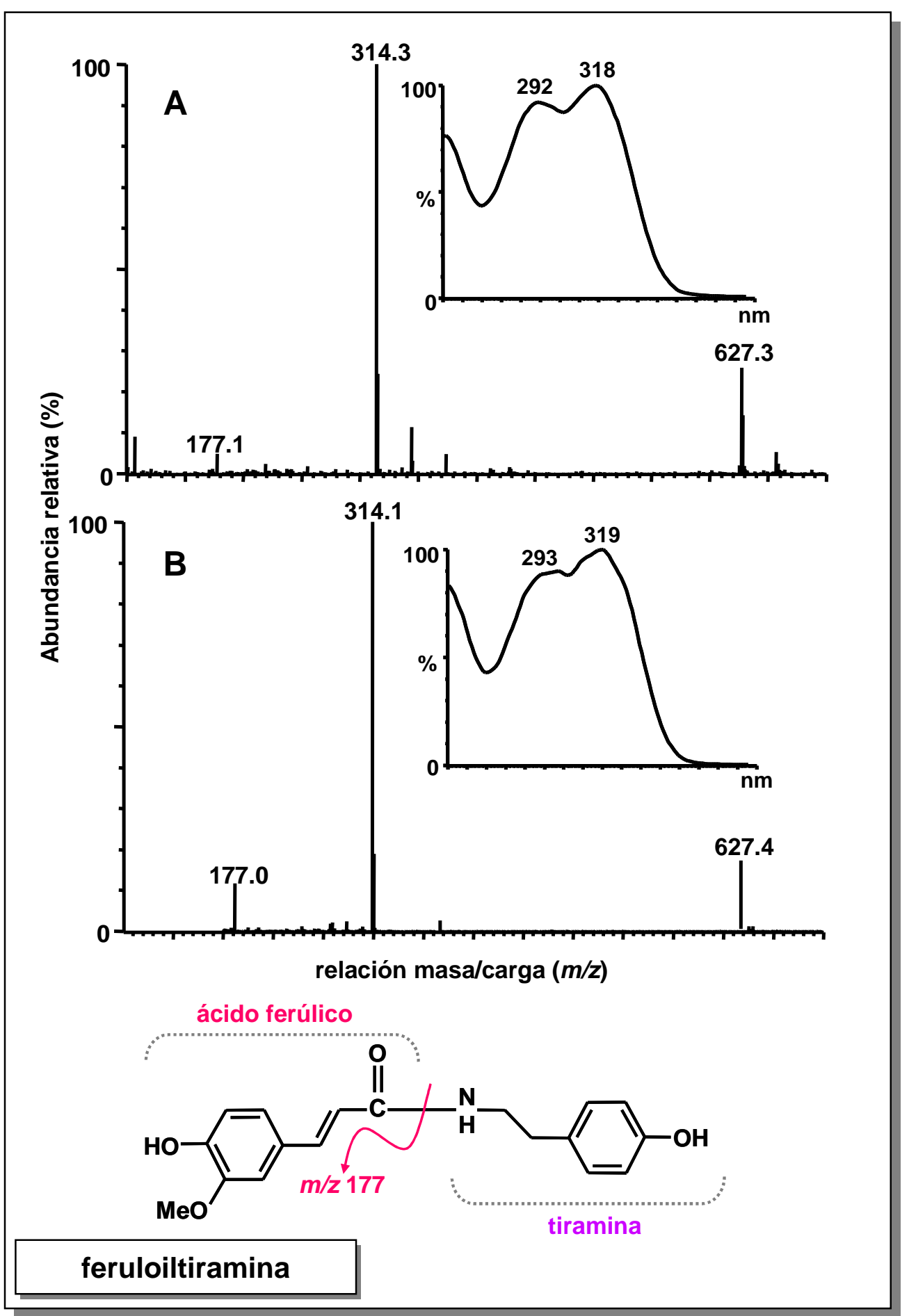

Figura 22. Espectros de masas y de absorción en el UV relativos al compuesto 4. (A) Espectro de masas obtenido mediante la técnica de ionización por electro-spray y espectro de absorción al UV del compuesto 4 detectado en extractos metanólicos de hojas de tomate 'Rutgers' infectadas con Pseudomonas syringae pv. tomato. (B) Espectro de masas obtenido mediante la técnica de ionización por electro-spray y espectro de absorción al UV de la feruloiltiramina sintetizada en el laboratorio. 
Nos encontramos, por tanto, ante cuatro moléculas de naturaleza fenólica, de estructura similar, resultado de la unión de un ácido derivado del ácido hidroxicinámico (ácido cumárico o ácido ferúlico) y una amina (tiramina o bien dopamina), mediante un enlace de tipo amida. Las HCAAs, constituyen un grupo de metabolitos secundarios de plantas de bajo peso molecular, que se caracterizan por la presencia de nitrógeno en su molécula (Facchini et al., 2002). Son numerosos los estudios que han demostrado la implicación de este tipo de compuestos en la defensa de las plantas frente a patógenos y en la respuesta a herida. La acumulación de HCAAs en respuesta a una infección se observó por primera vez en tubérculos de patata infectados con el hongo Phytophthora infestans (Clarke, 1982). A partir de entonces son numerosos los trabajos que han descrito la acumulación de este tipo de compuestos en respuesta a una infección, principalmente en la familia de las Solanáceas (Negrel et al., 1996; Pearce et al., 1998; Newman et al., 2001; von Roepenack-Lahaye et al., 2003). Von Roepenack-Lahaye et al. (2003) observaron que se producía una acumulación de $p$-cumaroiltiramina y $p$ cumaroilnoradrenalina en plantas de tomate Río Grande infectadas con la bacteria Pseudomonas syringae, sin embargo, dichos autores no detectaron la acumulación de las HCAAs descritas en la presente tesis, lo que indica un comportamiento diferencial entre variedades de tomate. También en tomate se ha descrito la acumulación de $p$ cumaroiltiramina y feruloiltiramina en respuesta a herida (Pearce et al., 1998). Sin embargo, es la primera vez que se describe la acumulación de $p$-cumaroildopamina y feruloildopamina en plantas en respuesta a una infección. Además, hemos podido observar la acumulación de las cuatro HCAAs descritas en el presente trabajo en otras variedades de tomate (Ailsa Craig, Moneymaker y UC82) en respuesta a Ps. syringae, de forma similar a como ocurre en Rutgers.

Como ya se ha comentado, en el cromatograma de la figura 18 , se observa la aparición de un pico adicional (compuesto 2') con un tiempo de retención ligeramente inferior al de la $p$-cumaroiltiramina (compuesto 3). En la naturaleza, la forma más abundante de los ácidos derivados del ácido hidroxicinámico (ácido cumárico, ferúlico, cafeico y sinápico) es la trans. Consistentemente con este hecho, en el presente trabajo se ha encontrado que los ácidos componentes (ferúlico y cumárico) de las HCAAs identificadas están también en su forma trans. Sin embargo, durante el proceso de extracción de compuestos fenólicos de plantas, la luz puede isomerizar parte de estas formas trans a formas cis (Towers, 1984). En un cromatograma, el tiempo de retención de la forma cis de cualquiera de estas amidas es un poco inferior al de la forma trans 
correspondiente. Sin embargo, las formas cis y trans presentan idénticos espectros de masas y de absorción al UV. En un principio, puesto que el tiempo de retención del compuesto 2' era ligeramente inferior al del compuesto 3, pensamos que dicho compuesto 2' podría ser el isómero cis de la p-cumaroiltiramina (compuesto 3). Dicha hipótesis se descartó al observar que su espectro de absorción en el UV era diferente al de cada uno de los compuestos estudiados. Se trata, por tanto, de un compuesto fenólico diferente a los cuatro anteriormente descritos, que no hemos podido identificar hasta el momento.

\section{IV.1.3.- Acumulación de las HCAAs en tomate infectado con Pseudomonas syringae pv. tomato.}

Con el fin de estudiar el perfil de acumulación de las cuatro HCAAs caracterizadas, se realizó una extracción de compuestos fenólicos de las hojas infectadas a diferentes tiempos post inoculación (17, 24, 48 y 72 horas post inoculación, hpi). Los extractos metanólicos de las hojas infectadas fueron analizados por HPLC con el fin de determinar no sólo el perfil de acumulación de las amidas, sino también los niveles alcanzados en la planta. Para cuantificar los niveles se utilizaron las curvas patrón elaboradas para cada compuesto, tal y como se describe en el apartado de Materiales y Métodos.

La figura 23 muestra los resultados obtenidos del análisis de la acumulación de las cuatro HCAAs en hojas de tomate infectadas con la bacteria Pseudomonas syringae pv. tomato durante las 72 horas posteriores a la inoculación (hpi). Como puede observarse en dicha figura, los patrones de acumulación de CD y CT son bastante similares entre sí. Los niveles de ambos compuestos alcanzan un máximo relativo a las 24 hpi y luego vuelven a crecer. Los otros dos metabolitos, FD y FT alcanzan un máximo en sus niveles de acumulación a las 24 hpi, decreciendo posteriormente. De las cuatro amidas la FD es la que alcanza los niveles más elevados (46 nmol/g de peso fresco a las $24 \mathrm{hpi})$, y la CD la que se acumula en menor medida $(1.7 \mathrm{nmol} / \mathrm{g}$ de peso fresco a las $24 \mathrm{hpi})$.

Con objeto de localizar la acumulación de las cuatro HCAAs detectadas, se compararon sus niveles en dos zonas de las hojas infectadas: las manchas necróticas, que incluían el área infiltrada más $1 \mathrm{~mm}$ de tejido adyacente sin inocular (zona A, figura 24), y el resto de la hoja donde no se había infiltrado la bacteria (Zona B, figura 24). 
Como puede apreciarse en la figura 24 la acumulación de los metabolitos detectados se da fundamentalmente en la zona A, en la zona B la acumulación de dichos compuestos es muy baja a pesar de que los niveles bacterianos son apreciables. Estos resultados son similares a los obtenidos por Pearce et al. (1998) y Guillet y De Luca (2005) en hojas de tomate o de tabaco heridas, respectivamente. Asimismo, también se realizaron extracciones de hojas distintas a las infectadas (hojas sistémicas), no detectándose acumulación de estos compuestos en dichas hojas, lo que indica que éstos no se inducen sistémicamente.

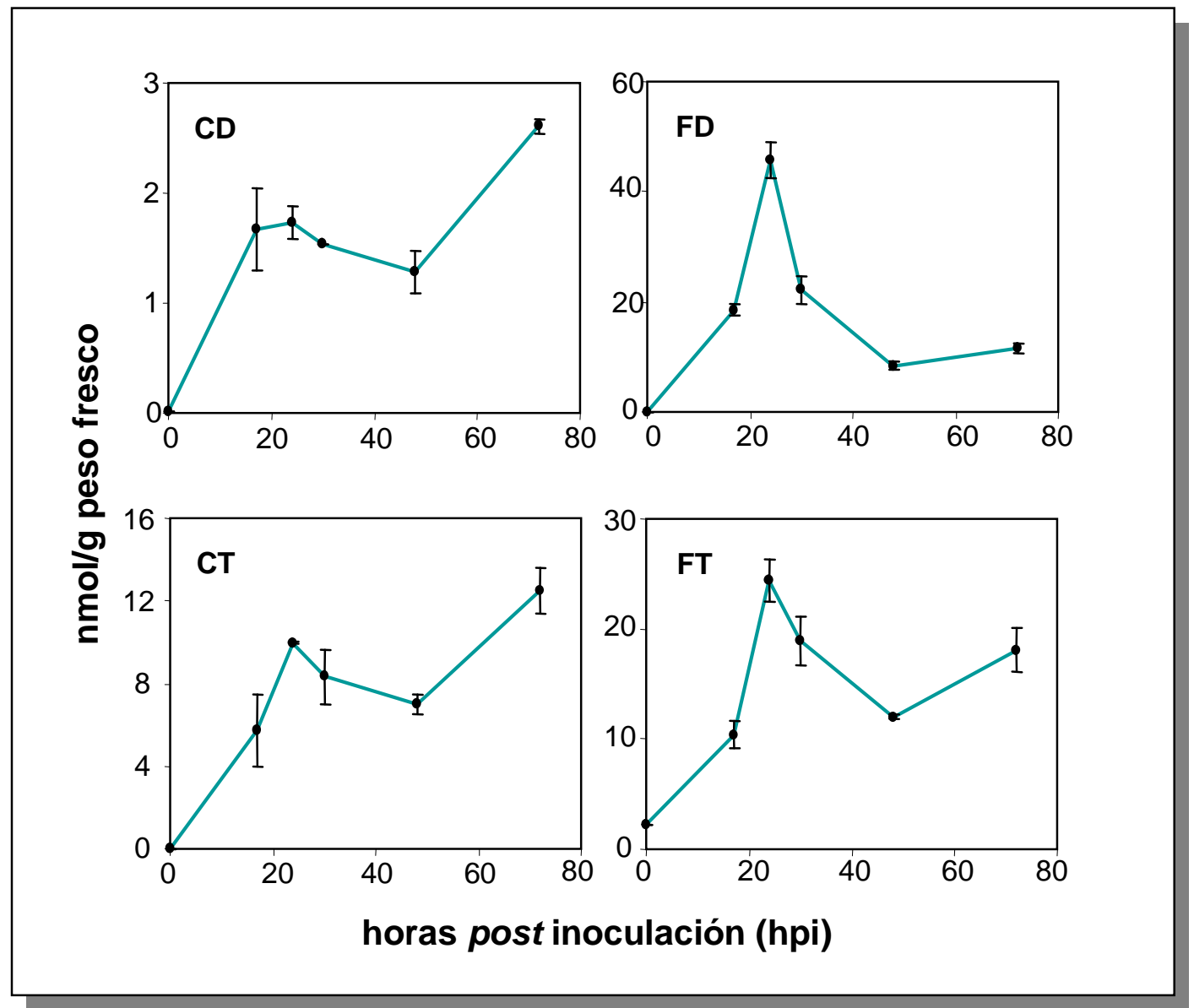

Figura 23. Patrón de acumulación de $p$-cumaroildopamina (CD), feruloildopamina (FD), p-cumaroiltiramina (CT) y feruloiltiramina (FT) en tomate 'Rutgers' infectado con Pseudomonas syringae. La figura muestra la acumulación de las cuatro HCAAs durante las 72 horas posteriores a la inoculación. 


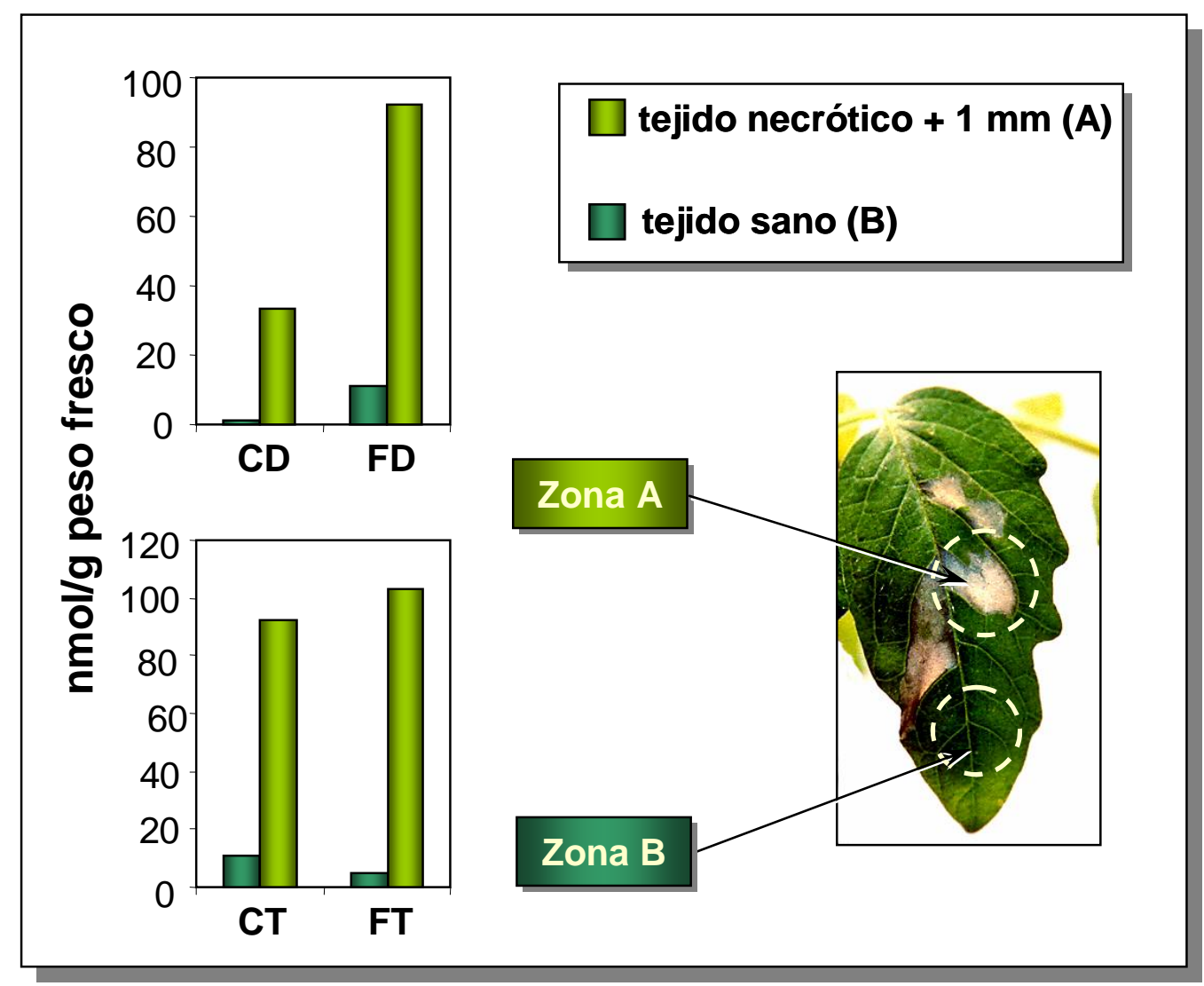

Figura 24. Niveles de acumulación de las cuatro HCAAs en distintas zonas de las hojas de tomate 'Rutgers' infectadas con la bacteria Pseudomonas syringae. La zona A representa el área infiltrada con la bacteria más $1 \mathrm{~mm}$ del tejido adyacente sin inocular. La zona B representa el resto de la hoja donde no se ha infiltrado la bacteria. Las cuatro HCAAs se acumulan principalmente en el área infiltrada (zona A). CD, p-cumaroildopamina; FD, feruloildopamina; CT, p-cumaroiltiramina; FT, feruloiltiramina. 
Normalmente, los compuestos fenólicos inducidos en la planta en respuesta a una infección se encuentran, parte en forma libre y parte conjugados con azúcares en forma de $\alpha$ ó $\beta$-glucósidos. Así, se ha encontrado que la mayor parte del SA extraído en tomate o en tabaco, se encuentra conjugado con la glucosa en forma de enlace Oglucosídico en posición $\beta$. Otro de los compuestos fenólicos descrito en nuestro laboratorio como implicado en la respuesta a patógenos, el ácido gentísico (GA) (Bellés et al., 1999), en cambio, está conjugado en forma de xilósido (Fayos et al., 2006). La conjugación a un azúcar constituye una forma de almacenamiento (Harborne 1980) y la hidrólisis de las formas conjugadas proporciona una fuente de HCAAs en forma libre, como alternativa a su biosíntesis. Con el fin de comprobar si nuestras HCAAs se encontraban conjugadas a azúcares en forma de $\alpha$ ó $\beta$-glucósidos, realizamos una hidrólisis con $\alpha$ ó $\beta$-glucosidasa respectivamente, de los extractos metanólicos de las hojas de tomate infectadas. Después de la hidrólisis, no se produjo ninguna alteración detectable en el nivel de los referidos compuestos. Para descartar la posibilidad de que estos compuestos estuvieran conjugados en forma de ésteres, se hizo una hidrólisis con esterasa, que tampoco produjo aumento en los niveles de amidas libres. Todo ello indica que los compuestos estudiados se encuentran en forma libre y no se acumulan conjugados a azúcares. Newman et al. (2001) obtuvieron resultados similares para el caso de la CT y de la FT en hojas de pimiento infectadas con la bacteria Xanthomonas campestris.

Los niveles de acumulación de las cuatro amidas en hojas de tomate 'Rutgers' infectadas con la bacteria Pseudomonas syringae pv. tomato son comparables a los observados para FT y CT en hojas de pepino infectadas con Xanthomonas campestris (Newman et al., 2001) y en patata infectada con en hongo Phytophthora infestans. También a los de $p$-cumaroilnoradrenalina y $p$-cumaroiloctopamina en hojas de tomate Río Grande infectadas con Pseudomonas syringae (Von Roepenack-Lahaye et al., 2003). Además, el hecho de que estos compuestos se acumulen principalmente en la zona infectada, es consistente con la idea de que pudieran ser tóxicos per se para el patógeno (Pearce et al., 1998). El hecho de que no se hayan encontrado conjugados a pared celular, sino en forma libre, apoya dicha hipótesis.

Recientemente, Niehl et al. (2006), después de estudiar la interacción compatible necrotizante entre Solanum tuberosum y el virus X de la patata $(P V X)$, hipotetizaron que tanto la tiramina como la dopamina (ambas fuertemente inducidas durante la infección), podrían contribuir a la respuesta defensiva de las plantas formando amidas derivadas del 
ácido hidroxicinámico, lo que contribuiría a estabilizar y reforzar la pared celular. Sin embargo, dichos autores no fueron capaces de detectar en el material vegetal infectado, la presencia de HCAAs derivadas de la tiramina o de la dopamina. En la presente tesis doctoral, hemos detectado dichas amidas en plantas de tomate infectadas con un patógeno que produce una infección necrotizante. Los resultados presentados extienden la acumulación de HCAAs a nuevos sistemas planta-patógeno, además de los ya descritos por otros autores (Newman et al., 2001; Von Roepenack-Lahaye et al., 2003), y lo que es más importante: aporta dos nuevos componentes (la $p$-cumaroildopamina y la feruloildopamina) pertenecientes a este grupo de metabolitos secundarios de plantas.

\section{IV.2.- La inducción de la tiramina hidroxicinamoil transferasa (THT) precede a la acumulación de CD, FD, CT y FT.}

El isoenzima THT1-3 es el responsable de la síntesis de las HCAAs (Von Roepenack-Lahaye et al., 2003). Con el fin de comprobar si la acumulación de las HCAAs observada en el presente trabajo podía deberse a la inducción de dicho isoenzima, se estudió la evolución del mRNA correspondiente. Para ello, se hizo un seguimiento mediante, aislamiento de RNA total y posterior RT-PCR, a las 5, 17, 24, y 48 horas posteriores a la inoculación. El RNA transcrito comienza a acumularse a las 5 hpi, detectándose los niveles máximos a las 24 hpi, para disminuir posteriormente (figura 25). Las hojas control no muestran alteración alguna en los niveles del gen. La comparación entre los patrones de acumulación de las HCAAs (figura 23) y del gen THT (figura 25), nos permite asociar la producción de las amidas con los cambios en los niveles de transcripción de la THT. En apoyo a esta idea, es pertinente resaltar que el aumento de los niveles de expresión del gen THT es anterior al incremento en los niveles de producción de las HCAAs. Estos resultados sugieren que la activación de la expresión del gen THT contribuye a incrementar los niveles de acumulación de las cuatro amidas (CD, FD, CT y FT), de forma similar a como ya había sido descrito por otros autores en otras interacciones planta-patógeno (Newman et al., 2001; Von Roepenack-Lahaye et al., 2003). El patrón de acumulación del gen THT observado en 'Rutgers' es similar al descrito por Von Roepenack-Lahaye et al. (2003) en tomate Río Grande infectado con Pseudomonas syringae, y es también comparable con el observado en cultivos celulares de patata tratadas con elicitores de la bacteria 
Pseudomonas infestans (Schmidt et al., 1999) y en pimiento infectado con Xanthomonas campestris (Newman et al., 2001).

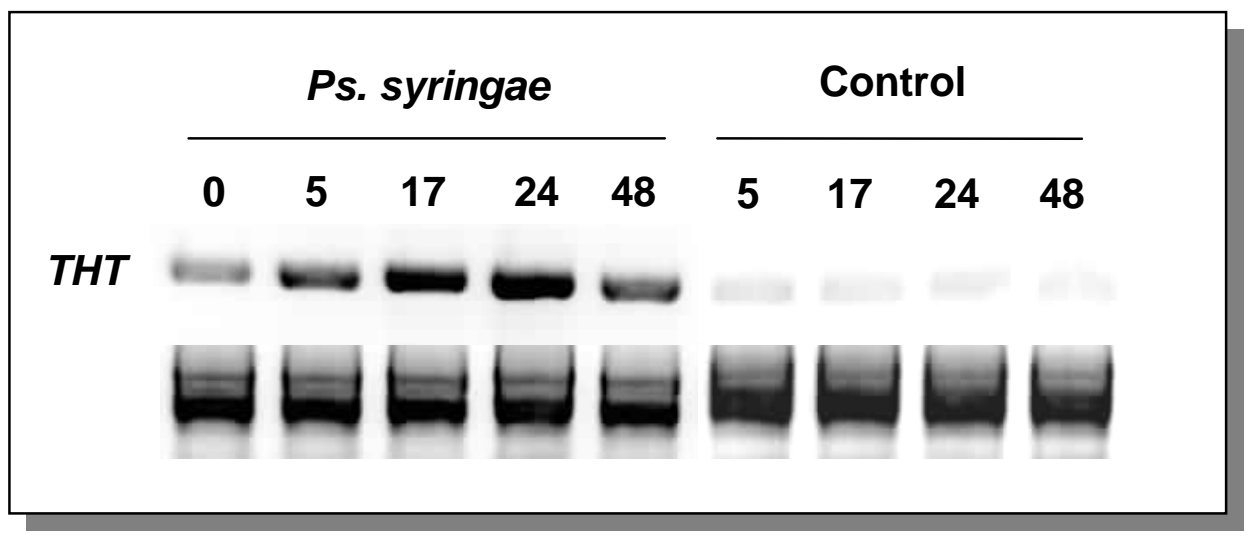

Figura 25. Patrón de acumulación de THT. La figura muestra los niveles de expresión del mRNA del isoenzima THT1-3 en hojas de tomate infectadas con la bacteria $P s$. syringae, a diferentes tiempos post inoculación $(5,17,24$ y 48 hpi), mediante análisis por RT-PCR. El panel inferior representa el RNA extraído de las muestras analizadas, utilizado como control de carga. 


\section{IV.3.- Estudio de la posible implicación del ácido salicílico (SA) y del etileno (ET) en la inducción patogénica de las HCAAs.}

\section{IV.3.1.-La activación de la síntesis de las HCAAs sigue una vía independiente de SA.}

La función fisiológica mejor caracterizada del ácido salicílico (SA) es la de la activación de programas de defensa inducibles, confiriendo a la planta resistencia frente a patógenos (Métraux y Raskin, 1993; Dempsey et al., 1999; Álvarez, 2000). En nuestro laboratorio, hemos comprobado que la infección de tomate con Pseudomonas syringae pv. tomato produce un rápido incremento en los niveles de SA (Bellés et al., 1999). Con el fin de verificar la posible mediación del SA en la inducción de las HCAAs, se utilizaron plantas $N a h G$. Las plantas de tomate $N a h G$ son plantas transgénicas que no pueden acumular SA porque sobreexpresan el gen bacteriano que codifica la salicilato hidroxilasa, enzima que transforma el ácido salicílico en catecol (Brading et al., 2000). De igual modo a como habíamos hecho en plantas de tomate 'Rutgers', plantas de tomate $N a h G$ fueron infectadas con la bacteria Pseudomonas syringae pv. tomato, tal y como se describe en el apartado Materiales y Métodos. La figura 26 A representa la acumulación de HCAAs en hojas infectadas de las plantas $N a h G$ a las 24 y 48 horas post inoculación (hpi), el nivel de esas HCAAs en los controles no infectados es indetectable. Para asegurarnos de que el SA no se acumulaba en las plantas NahG durante la infección bacteriana, se midió el nivel de SA acumulado en las hojas de tomate $N a h G$ infectadas. Como era de esperar no se observó acumulación de SA (figura $26 \mathrm{~B})$, al contrario de lo que sucede en plantas Moneymaker infectadas, que fueron utilizadas como control (figura $26 \mathrm{C}$ ). Los niveles de HCAAs alcanzados en las plantas $N a h G$ infectadas son del mismo orden que los observados en tomate 'Rutgers'. Estos resultados indican que la acumulación de las cuatro HCAAs objeto de estudio, es independiente del ácido salicílico, señal intermediaria de la respuesta defensiva de tomate frente a Pseudomonas syringae pv. tomato. En cambio, existen metabolitos secundarios de respuesta a patógenos cuya inducción si depende de SA, como es el caso de la camalexina en plantas de Arabidopsis thaliana (Nawrath y Métraux, 1999).

Con el fin de proporcionar una base experimental más sólida a la idea anterior, se estudió el efecto de un tratamiento exógeno con SA, tal y como se describe en el 
apartado de Materiales y Métodos. No detectamos acumulación de HCAAs en las hojas tratadas con SA, a pesar de que el tratamiento se realizó a una concentración de SA capaz de activar programas de defensa en tomate (Van Kan et al., 1995; Bellés et al., 1999).
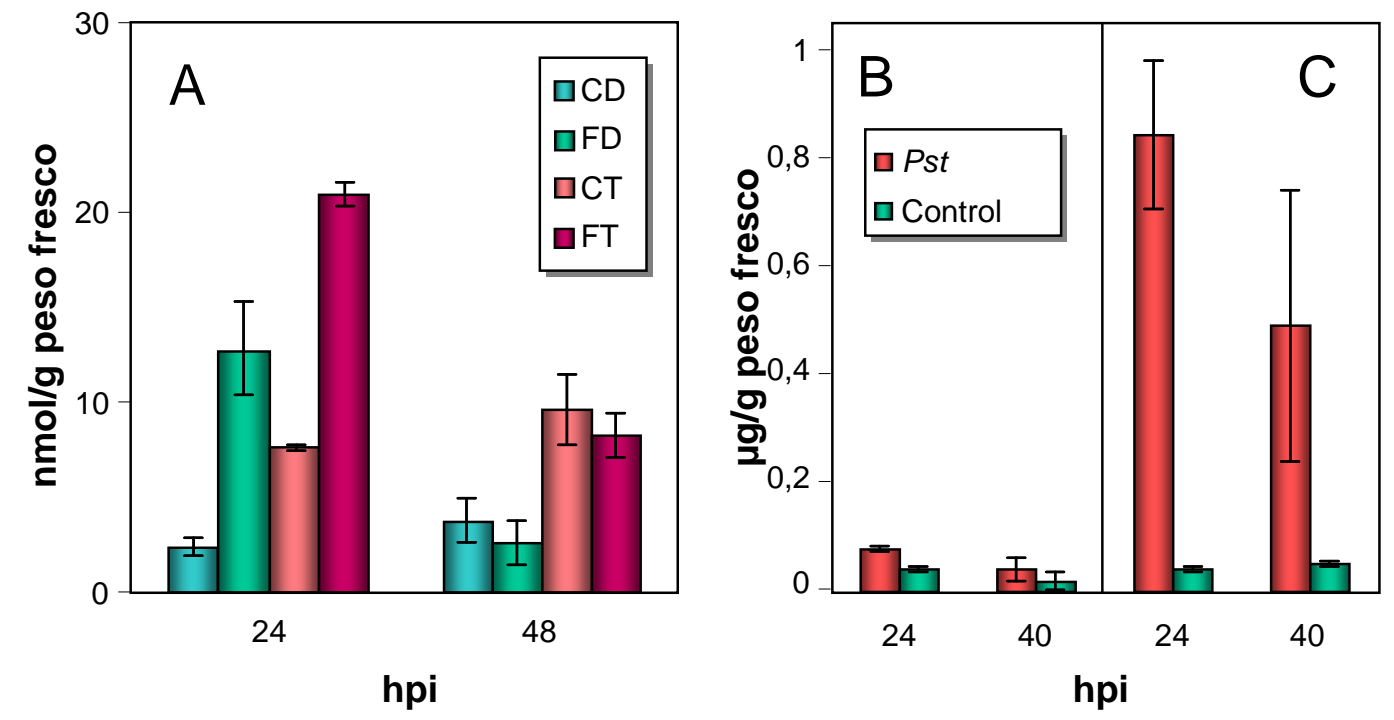

Figura 26. Análisis de compuestos fenólicos en plantas de tomate $N a h G$ infectadas con la bacteria Pseudomonas syringae pv. tomato. (A) Acumulación de $p$-cumaroildopamina (CD), feruloildopamina (FD), p-cumaroiltiramina (CT) y feruloiltiramina (FT) en extractos metanólicos de muestras hojas de tomate NahG infectadas con Pseudomonas syringae pv. tomato, tomadas a las 24 y 48 horas post inoculación (hpi). Los niveles de HCAAs en las plantas control no infectadas son indetectables. (B) Acumulación de ácido salicílico en extractos metanólicos de muestras de hojas de tomate NahG infectadas con Pseudomonas syringae pv. tomato (Pst), tomadas a las 24 y 40 hpi. (C) Acumulación de ácido salicílico en extractos metanólicos de muestras de hojas de tomate Moneymaker infectadas con Pseudomonas syringae pv. tomato, tomadas a las 24 y $40 \mathrm{hpi}$. 


\section{IV.3.2.- El etileno es esencial para la inducción de la expresión del gen $T H T$ y para la acumulación de las HCAAs.}

El etileno es una hormona vegetal que juega un papel muy importante en la señalización de la respuesta defensiva de las plantas (Van Loon et al. 2006a). Sin embargo, el papel que desempeña dicha hormona en la defensa frente a patógenos no se conoce bien: en algunos casos se ha creído que estaba relacionado con la inducción de fitoalexinas (Boller, 1990), mientras que en algunas interacciones planta-patógeno no parecía estar implicado en dicha inducción (Boller, 1990; Reinhardt et al., 1991).

En estudios previos sobre la interacción entre tomate 'Rutgers' y Ps. syringae, se ha demostrado que la infección de las hojas de tomate con dicho patógeno provocaba la síntesis de etileno. Por tanto, con el fin de establecer la posible relación del incremento del nivel de etileno producido en tomate como consecuencia de la infección con Pseudomonas syringae pv. tomato con la activación de la expresión del gen THT y la acumulación de CD, FD, CT y FT, se realizó un tratamiento con aminoetoxivinilglicina (AVG), un inhibidor de la síntesis de etileno (Adams y Yang 1979), en lugar de utilizar mutantes de tomate PTOM 13 afectados en la producción de etileno. Ello se debe a que hemos comprobado que la inhibición de la producción de etileno por el tratamiento con AVG es mucho mayor a la observada en PTOM 13. El tratamiento y la posterior infección se llevó a cabo tal y como se describe en el apartado de Materiales y Métodos. Posteriormente se analizó la producción de etileno, la expresión de THT, y la acumulación de las HCAAs, a lo largo de la infección, comparando los resultados entre plantas tratadas y plantas no tratadas con AVG. La figura 27 A muestra el patrón de acumulación del etileno en hojas de tomate infectadas con la bacteria Pseudomonas syringae pv. tomato. Dicha inducción es similar a la encontrada por Ciardi et al. (2000) en hojas de tomate infectadas con Xanthomonas campestris. La síntesis de etileno comienza a observarse a partir de las 5 horas post inoculación, alcanzando su máximo a las 17 hpi, para descender después a unos niveles similares a los alcanzados a las 5hpi. La producción de etileno en las hojas no inoculadas no experimentó ningún incremento a lo largo de toda la infección. Asimismo, la aplicación exógena de AVG 1mM inhibió el aumento en la producción de etileno que se observaba a las 17 hpi en las hojas infectadas y a lo largo de toda la infección. Además el tratamiento con AVG también produjo una reducción en los niveles de expresión (mRNA) del gen THT, tal y como se muestra en la figura 27 B, así como un marcado descenso en la acumulación de CD, FD, 
CT y FT, a las 24 y 48 hpi (figura 27 C). Dicho descenso fue mayor en el caso de CT y FT, tanto a las 24 como a las 48 hpi. No se observó ningún descenso en los niveles de acumulación de las HCAAs a las 5 y 17 hpi (resultados no mostrados), probablemente debido a que el efecto del AVG en la expresión de THT es todavía muy bajo para poder apreciar efecto alguno en la síntesis de las amidas.

Estos resultados sugieren que, el etileno generado como consecuencia de la infección con Pseudomonas syringae, es necesario para la inducción de la expresión del gen THT, y para la acumulación de las HCAAs. Asimismo, corroboran la idea de la importancia atribuida al etileno en la señalización de la respuesta defensiva de tomate (Díaz et al., 2002; Conejero et al., 1990; Lund et al., 1998). 


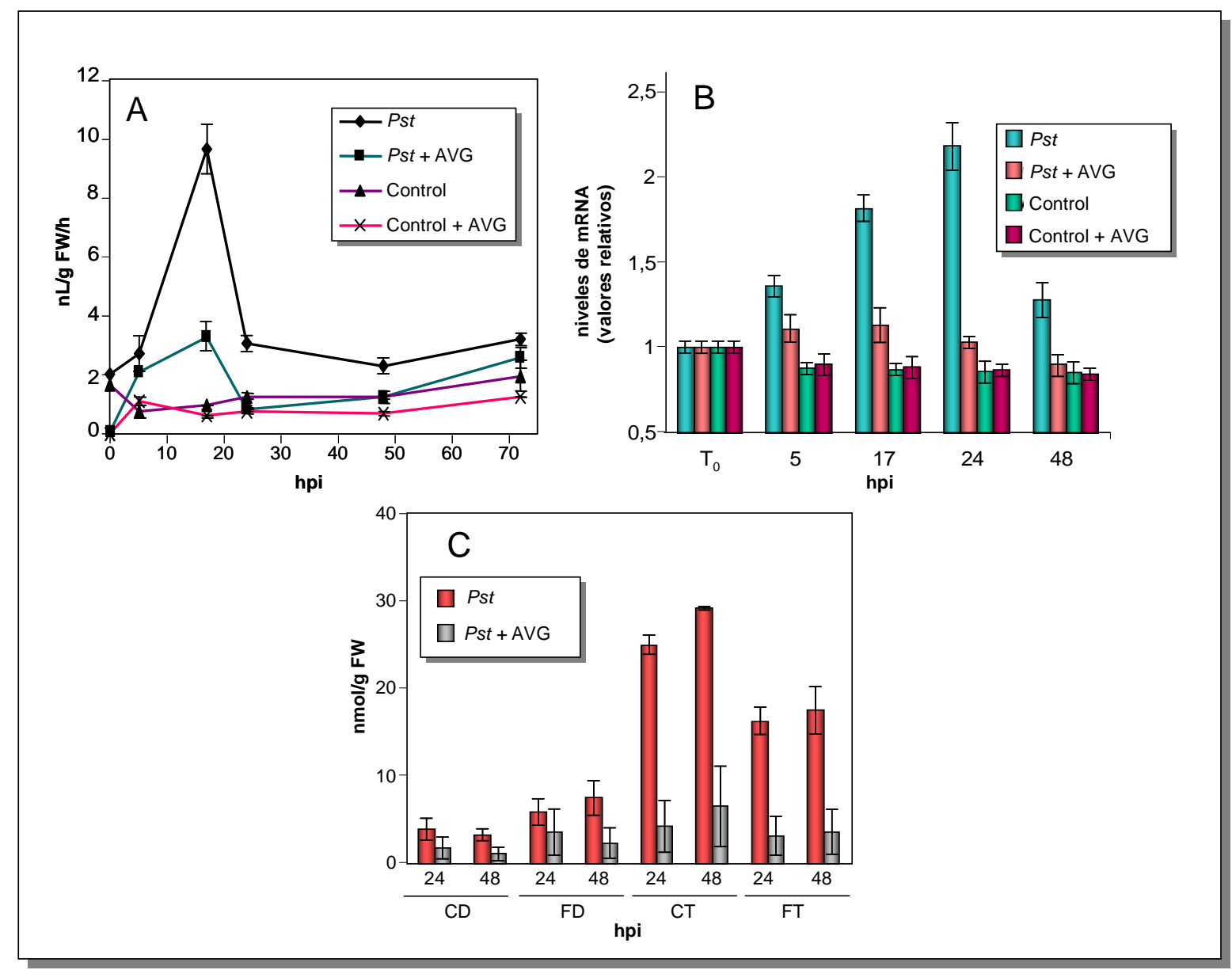

Figura 27. Efecto del AVG en la acumulación de $p$-cumaroildopamina (CD), feruloildopamina (FD), p-cumaroiltiramina (CT) y feruloiltiramina (FT) y del transcrito THT, en plantas de tomate 'Rutgers' infectadas con Pseudomonas syringae pv. tomato. (A) Estudio comparativo de la acumulación de etileno inducido por la infección con Pseudomonas syringae en plantas de tomate tratadas y no tratadas con AVG. El tratamiento con AVG inhibe el aumento en la producción de etileno observado a las 17 hpi en las hojas infectadas. (B) Análisis de los niveles de expresión del transcrito THT en hojas de tomate infectadas. (C) Acumulación de CD, FD, CT y FT en las 24 y 48 horas siguientes a la infección en plantas tratadas y no tratadas con AVG. El tratamiento con AVG reduce significativamente los niveles de acumulación de las cuatro amidas inducidas durante la infección bacteriana. 
Los experimentos con AVG demuestran que el aumento de etileno asociado a la infección patogénica es necesario para la inducción, tanto de la THT como de las HCAAs. Con objeto de ver si, además, dicha señal era suficiente, plantas de tomate 'Rutgers' fueron sometidas a un tratamiento con etileno $(50 \mu \mathrm{l} / 1)$, tal y como se indica en el apartado de Materiales y Métodos. En la figura 28A puede observarse como un tratamiento exógeno con etileno en plantas de tomate 'Rutgers' produce la acumulación de las cuatro HCAAs. Este resultado es coherente con el aumento en los niveles de expresión del gen THT como consecuencia del tratamiento (figura $28 \mathrm{~B}$ ), siendo este incremento comparable con el observado en plantas de tomate infectadas con Pseudomonas syringae. Es la primera vez que se asocia una señal de etileno a la expresión del mRNA de la THT y a la acumulación de HCAAs. 


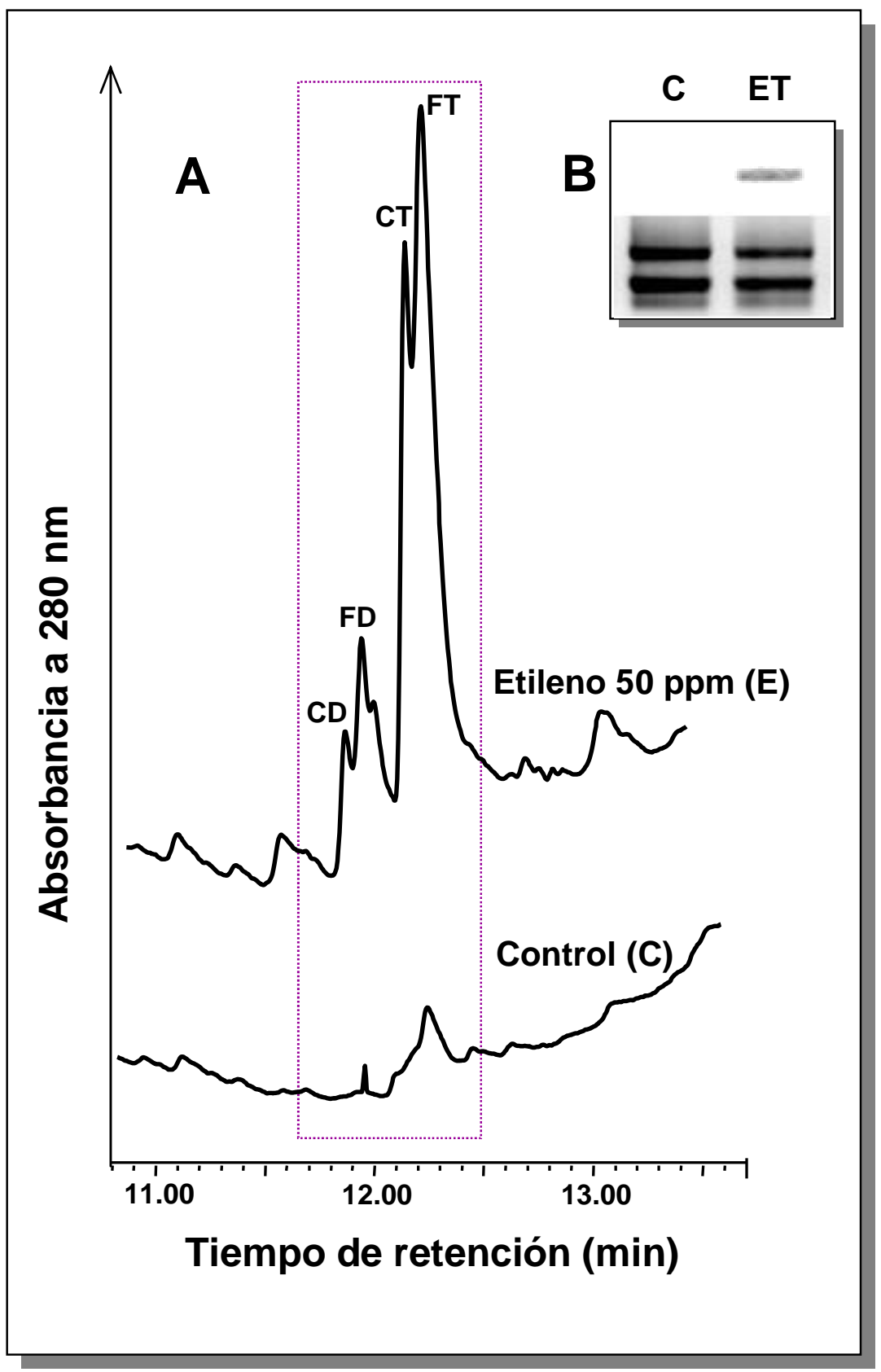

Figura 28. Efecto del tratamiento con etileno en la inducción del mRNA de la THT y la acumulación de $p$-cumaroildopamina (CD), feruloildopamina (FD), p-cumaroiltiramina (CT) y feruloiltiramina (FT), en plantas de tomate 'Rutgers'. (A) Análisis mediante HPLC de los extractos metanólicos de hojas de tomate tratadas con etileno $(50 \mu \mathrm{l} / \mathrm{l})$ durante 24 horas. (B) Análisis mediante RT-PCR de la expresión del transcrito de THT (mRNA) en hojas de tomate 'Rutgers' tratadas con etileno $(50 \mu \mathrm{l} / \mathrm{l})(\mathrm{ET})$, comparadas con el control (C). El panel inferior representa el RNA extraído de las muestras analizadas, utilizado como control de carga. 


\section{IV.4.- CD y FD poseen actividad antioxidante.}

En plantas, la presencia de metabolitos con propiedades antioxidantes podría impedir la acumulación de especies reactivas de oxígeno producidas como consecuencia de la infección patogénica (Matamoros et al., 2003). En este sentido, Niggeweg et al. (2004) demostraron que plantas transgénicas de tomate, capaces de acumular altos niveles de ácido clorogénico, poseían una mayor capacidad antioxidante y eran más resistentes a una infección bacteriana. Estudios previos han demostrado que los ácidos derivados del ácido hidroxicinámico son potentes antioxidantes naturales (Kikuzaki et al., 2002; Cos et al., 2002; Zhang et al., 1996). Hasta el momento no se ha investigado esta actividad antioxidante en HCAAs derivadas de la tiramina y de la dopamina. En el presente trabajo, se ha estudiado la actividad antioxidante de las HCAAs y de sus precursores (los ácidos p-cumárico y ferúlico, la tiramina, y la dopamina). Dicha actividad fue evaluada mediante el ensayo basado en la inactivación del radical libre estable 2,2-difenil-1-picrilhidracil (DPPH) (Hirota et al., 2000). Los resultados presentados en la tabla 2 muestran que la CD y la FD poseen una fuerte actividad antioxidante frente al radical DPPH, comparable a la del control positivo utilizado BHT. La actividad antioxidante de las HCAAs derivadas de la tiramina (CT y FT) fue significativamente menor que la obtenida en el caso de las amidas derivadas de la dopamina ( $C D$ y FD). Este resultado es coherente con la actividad antioxidante observada para la dopamina y la tiramina. En efecto, la capacidad de inactivación del radical libre DPPH de la dopamina es mucho mayor que la de la tiramina. Tal y como sugirieron Cos et al. (2002), nuestros resultados confirman que la presencia de dopamina es crucial en la inactivación del DPPH. 


\begin{tabular}{lc}
\hline Compuesto & $\mathbf{E D}_{50}(\boldsymbol{\mu M})$ \\
\hline$p$-cumaroildopamina & $56.37 \pm 0.01$ \\
feruloildopamina & $77.96 \pm 0.03$ \\
$p$-cumaroiltiramina & $>200$ \\
feruloiltiramina & $150.15 \pm 0.1$ \\
ácido $p$-cumárico & $>200$ \\
ácido ferúlico & $47.18 \pm 0.01$ \\
dopamina & $11.30 \pm 0.01$ \\
tiramina & $>200$ \\
\hline BHT & $61.13 \pm 0.02$ \\
\hline
\end{tabular}

Tabla 2. Cuantificación de la capacidad antioxidante in vitro de $p$-cumaroildopamina (CD), feruloildopamina (FD), p-cumaroiltiramina (CT) y feruloiltiramina (FT), y de sus precursores (ácidos cumárico y ferúlico, tiramina y dopamina). Los valores de la tabla representan la concentración necesaria de producto para reducir a la mitad la absorbancia del DPPH. Como control del experimento se utilizó el antioxidante comercial BHT.

\section{IV.5.- CD y FD poseen actividad antibacteriana.}

La actividad antifúngica y antibacteriana está muy extendida en los compuestos fenólicos sintetizados por las plantas en respuesta a una infección (Dixon 2001). Sin embargo, son pocos los estudios realizados sobre dicha actividad en HCAAs (Grandmaison et al., (1993); McLusky et al., 1999; Newman et al., 2001; von Roepenack-Lahaye et al., 2003). En la presente tesis doctoral, se ha estudiado la actividad antibacteriana in vitro de la $p$-cumaroiltiramina, la feruloiltiramina, la $p$ cumaroildopamina y la feruloildopamina. Hemos observado que estas dos últimas muestran una notable actividad antibacteriana in vitro frente a Pseudomonas syringae pv. tomato (figura 29 A y B). Este resultado sugiere que estas dos nuevas HCAAs podrían estar actuando directamente como agentes antimicrobianos en tomate durante la infección con Pseudomonas syringae pv. tomato. Sorprendentemente, en el caso de la CT y la FT no hemos sido capaces de encontrar un efecto significativo. Este resultado contrasta con el obtenido por Newman et al. (2001) para Xanthomonas campestris pv. campestris. Sin embargo, otros autores como Grandmaison et al., (1993) y McLusky et al. (1999), tampoco encontraron evidencias concluyentes de la acción antimicrobiana de CT y FT contra hongos. Los primeros observaron que CT y FT reducían el desarrollo de vesículas arbusculares en micorrizas, mientras que los segundos, no pudieron atribuir 
una actividad antifúngica a la CT y a la FT contra Botrytis alli y contra Botrytis cinerea. Otras HCAAs han mostrado una importante actividad antimicrobiana contra bacterias, como por ejemplo la $p$-cumaroilnoradrenalina (von Roepenack-Lahaye et al., 2003), y también contra hongos, como por ejemplo la $\beta$-feniletilamina serotonina, 3-(2aminoetil)-5-hydroxiindol (Tanaka et al., 2003).

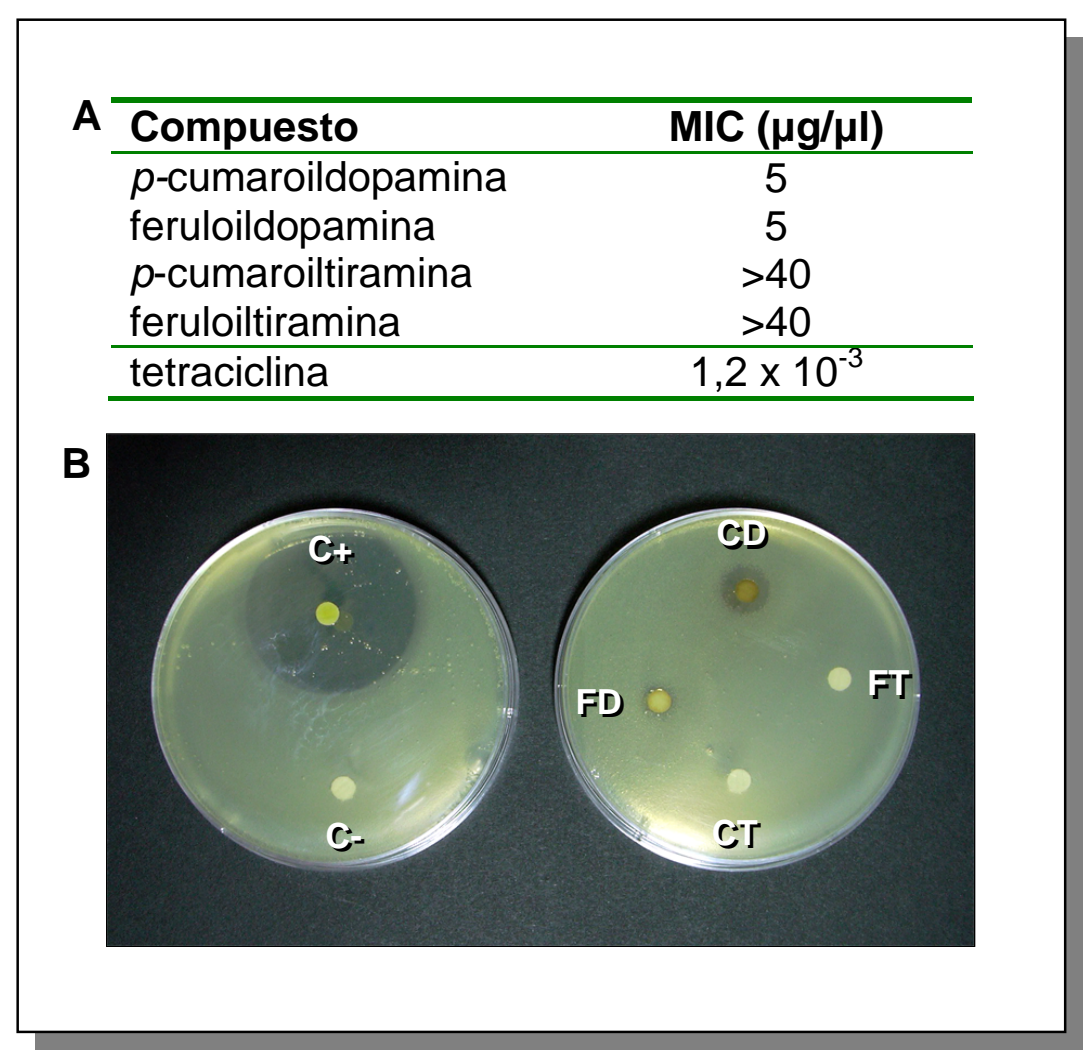

Figura 29. Ensayo de la actividad antibacteriana de $p$ cumaroildopamina (CD), feruloildopamina (FD), $p$-cumaroiltiramina (CT) y feruloiltiramina (FT). (A) Cuantificación de la actividad antibacteriana como concentración mínima inhibitoria (MIC, Minimal Inhibiory Concentration). (B) Halo de inhibición del crecimiento bacteriano alrededor de los discos impregnados con los productos ensayados. C+ representa un disco impregnado con tetraciclina. Crepresenta un disco impregnado únicamente con metanol. 


\section{IV.6.- Sobreexpresión del gen de la tiramina hidroxicinamoil transferasa (THT) en plantas transgénicas.}

Para los estudios sobre el posible papel tanto de las HCAAs como de la THT en la interacción patógeno-planta, un paso crítico es la obtención de plantas transgénicas que sobreexpresen o en las que se silencie el gen correspondiente a dicho enzima. En este sentido, la generación de plantas transgénicas que sobreexpresan THT es una herramienta que algunos autores han utilizado en otras especies para poder estudiar in vivo la función defensiva de dicha proteína así como de los metabolitos sintetizados por la misma (Hagel y Facchini, 2005; Lee et al., 2007).

\section{IV.6.1.- Arabidopsis thaliana como sistema modelo para la sobreexpresión de la THT.}

\section{IV.6.1.1.- Obtención de plantas transgénicas.}

En una primera aproximación a la obtención de plantas transgénicas con la THT modificada, hemos utilizado el sistema modelo Arabidopsis thaliana, más fácilmente transformable que el tomate. El estudio comparativo de secuencias de tomate y Arabidopsis thaliana, nos ha permitido encontrar dos genes en Arabidopsis (At2g39030 y At2g39020) que podrían desempeñar una posible función THT. Con el fin de analizar si el comportamiento de dichos genes en Arabidopsis era similar al observado para el gen THT1-3 de tomate, se estudió la inducción del mRNA correspondiente a uno de ellos, At2g39030, en hojas de plantas de Arabidopsis thaliana infectadas con la bacteria Pseudomonas syringae pv. tomato RpmI. Para ello, se hizo un aislamiento de RNA total y posterior RT-PCR, a las 24 horas posteriores a la inoculación (hpi) (figura 30). 


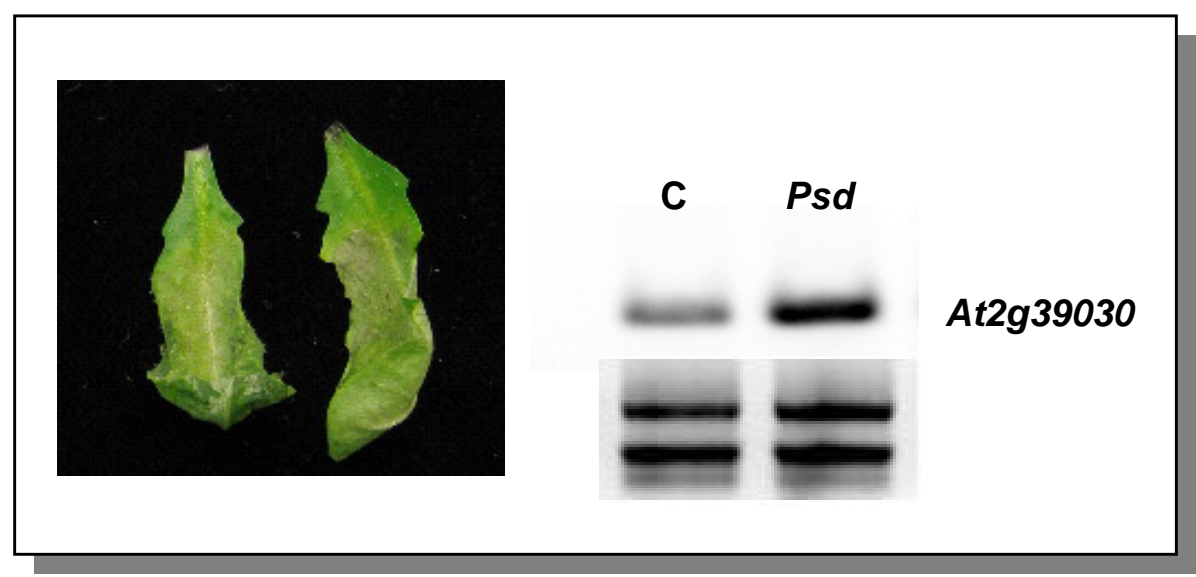

Figura 30. Acumulación de At2g39030 en hojas de Arabidopsis infectadas con la bacteria Pseudomonas. syringae. La figura muestra los niveles de expresión del mRNA del gen At2g39030 en hojas infectadas ( $P s d)$ y en hojas control no infectadas, a las 24 horas posteriores a la inoculación. El panel inferior representa el RNA extraído de las muestras analizadas, utilizado como control de carga. La fotografía de la izquierda representa dos hojas infectadas.

La inducción de At2g39030 observada a las 24 hpi en plantas de Arabidopsis infectadas con Pseudomonas syringae, es similar a la inducción de THT1-3 observada a las 24 hpi en plantas de tomate infectadas con esta misma bacteria (figura 25). A la vista de estos resultados, Arabidopsis thaliana nos pareció un sistema adecuado para poder estudiar in vivo la posible función defensiva de la proteína THT1-3 de tomate. Para ello, se generaron plantas transgénicas de Arabidopsis que la sobreexpresaran. La secuencia de cDNA del gen fue insertada en sentido directo en el plásmido binario pBI121::gus bajo el control transcripcional del promotor $35 S 2 X$ del virus del mosaico de la coliflor y con la señal de poliadenilación del gen de la nopalina sintasa. Se llevó a cabo la transformación genética de plantas de Arabidopsis de la variedad Columbia 0 con esta construcción. Como resultado de la transformación se obtuvieron 5 líneas de Arabidopsis resistentes a kanamicina (líneas $\mathrm{n}^{\circ}$ 1, 2, 4, 5 y 6). Se realizó la detección de la actividad $\beta$-glucuronidasa in situ en estas líneas y se observó dicha actividad en todas ellas. Para comprobar que el transgen se estaba sobreexpresando se realizó una purificación de RNA total y una posterior RT-PCR para cada una de las líneas (figura 31). Como puede verse en la figura 31 todas las líneas analizadas mostraron expresión constitutiva del gen THT1-3. 


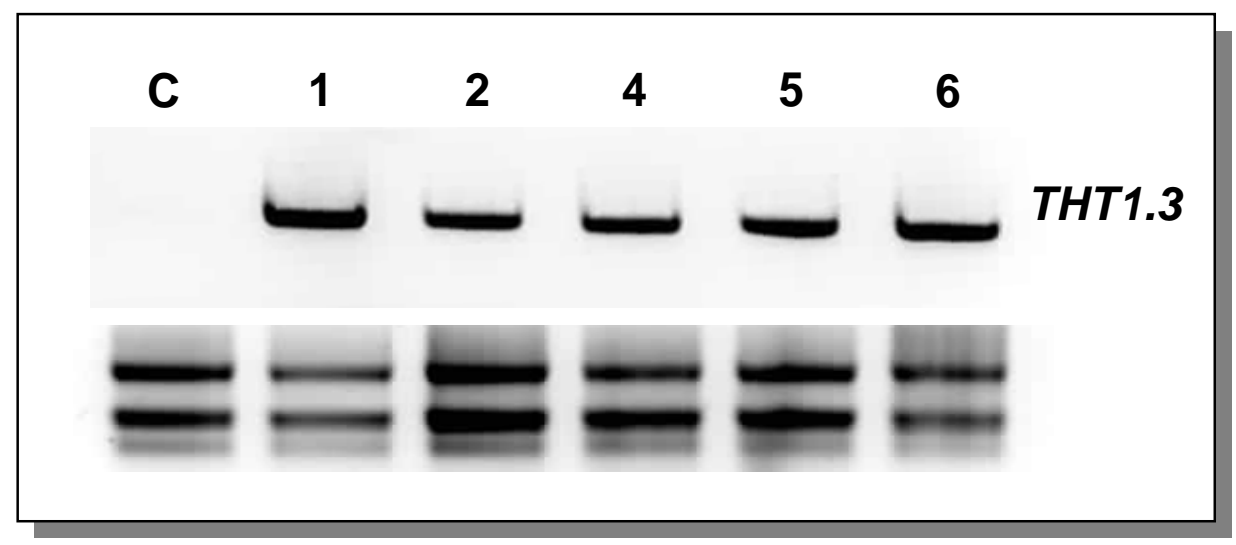

Figura 31. Acumulación del mRNA del isoenzima THT1-3 en las líneas transgénicas de Arabidopsis 1, 2, 3, 4 y 5. Análisis mediante RT-PCR de la expresión del transcrito de THT (mRNA) en hojas de las cinco líneas transgénicas comparadas con el control (C). El panel inferior representa el RNA extraído de las muestras analizadas, utilizado como control de carga.

\section{IV.6.1.2.- Estudio de la acumulación de HCAAs en plantas 35S2X::THT::nos} de Arabidopsis thaliana.

Con la finalidad de comprobar si las líneas transgénicas de Arabidopsis thaliana que sobreexpresan la THT1-3 de tomate acumulan de forma diferencial metabolitos relacionados con la actividad de dicho enzima (amidas derivadas del ácido hidroxicinámico, HCAAs), se llevó a cabo el análisis de los niveles de acumulación de compuestos fenólicos en las cinco líneas transgénicas obtenidas. Para ello se realizó una extracción metanólica de compuestos fenólicos de las hojas de las plantas transgénicas y de sus correspondientes controles, tal y como se describe en el apartado de Materiales y Métodos. Los extractos fueron analizados mediante HPLC-MS. En las cinco líneas analizadas se produce la acumulación de un pico diferencial con un tiempo de retención de 10.5 min y cuya masa molecular es de 343 unidades. En la figura 32 se muestra acumulación en una de las líneas (línea 5) comparada con una línea no transgénica (control). Sin embargo, no hemos encontrado acumulación de las HCAAs identificadas y caracterizadas en la presente tesis doctoral en ninguna de las líneas transgénicas obtenidas. Este resultado puede explicarse si se tiene en cuenta el hecho de que en Arabidopsis thaliana son muy abundantes los fenilpropanoides derivados del ácido sinápico, por ejemplo el sinapoilmalato (figura 32) (Hagemeier et al., 2001). Los ácidos 
p-cumárico y ferúlico son precursores biosintéticos del ácido sinápico (Hoffman et al., 2004) y, por tanto, la proteína sobreexpresada podría no encontrar en Arabidopsis los sustratos que emplea en tomate (ácidos p-cumárico y ferúlico) para sintetizar la HCAAs objeto de estudio, ya que éstos estarían siendo consumidos en la ruta del ácido sinápico. Se sabe que las THTs caracterizadas hasta el momento en tabaco (Farmer et al., 1999), en patata (Schmidt et al., 1999), en pimiento (Back et al., 2001) y en tomate (von Roepenack-Lahaye et al., 2003) muestran una mayor afinidad por los ácidos ferúlico y cumárico. Sin embargo, Ishihara y colaboradores (2000) han encontrado que el ácido sinápico es también un buen sustrato para la THT que han caracterizado en hojas de maíz. Basándonos en este dato y en la masa molecular (343 unidades), el compuesto diferencial detectado en las plantas transgénicas, podría corresponder a una nueva HCAA, la sinapoiltiramina (figura 33). No obstante, será necesario realizar análisis más precisos que revelen la identidad inequívoca de dicho compuesto, labor que se pretende llevar a cabo en el futuro. 


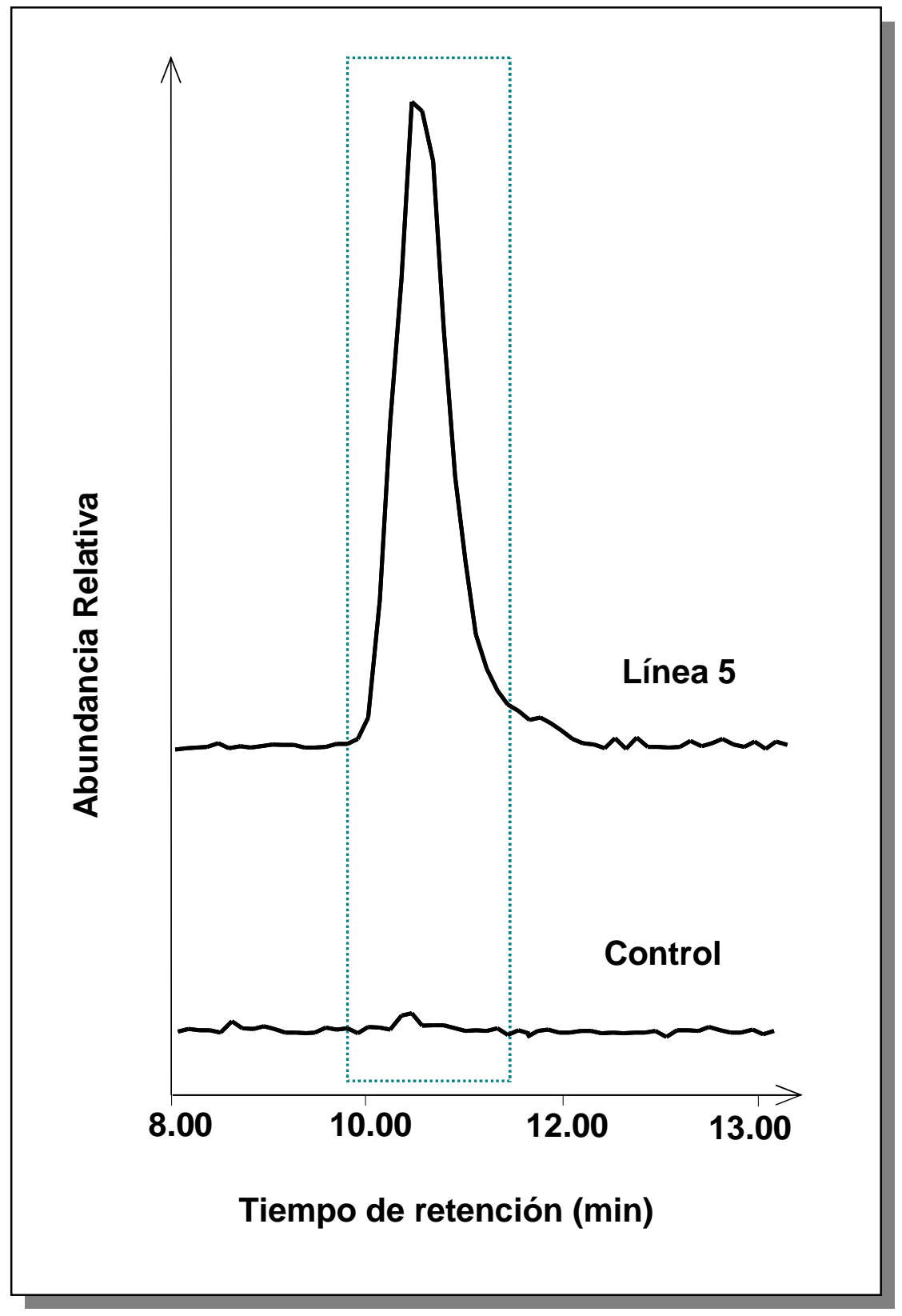

Figura 32. Análisis de la acumulación de compuestos fenólicos en las líneas transgénicas de Arabidopsis thaliana. En la figura se muestra la acumulación diferencial de un compuesto con un tiempo de retención de 10.5 min y una masa de 343 unidades en la línea 5. Dicha acumulación se produce en las cinco líneas analizadas. Los datos que se muestran corresponden a un cromatograma obtenido en la modalidad de scan en positivo. 


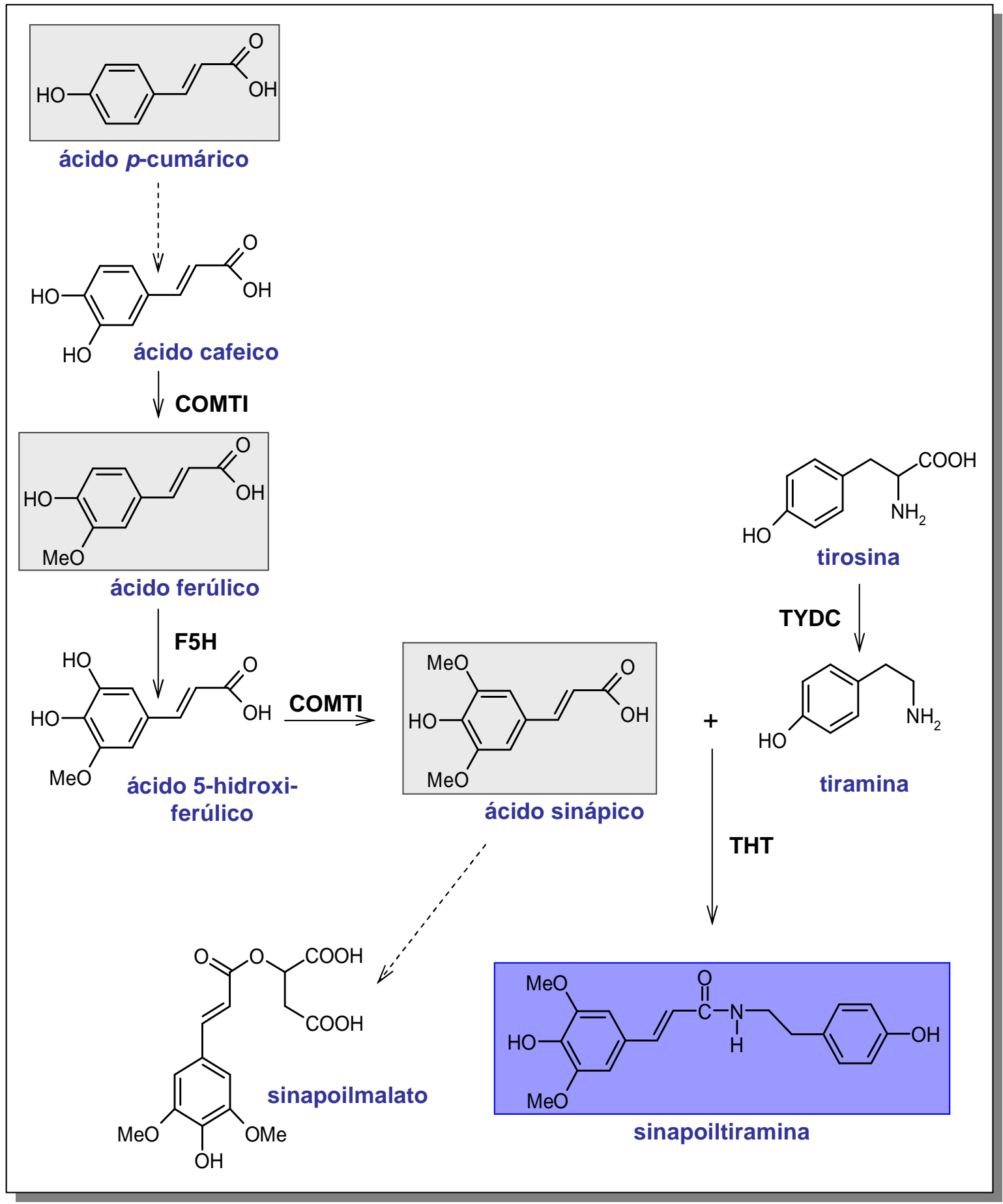

Figura 33. Ruta biosintética del ácido sinápico. COMT I, ácido cafeico/5-hidroxiferúlico Ometiltransferasa; F5H, ferulato 5-hidroxilasa; TYDC, tirosina decarboxilasa; THT, tiramina hidroxicinamoil transferasa. Adaptado de Hoffman et al. (2004). 
IV.6.2.- Sobreexpresión de la THT en plantas de tomate Solanum lycopersicon cv. UC82.

IV.6.2.1.- Obtención de plantas transgénicas de tomate portadoras de la construcción 35S2X::THT1-3::nos.

Paralelamente a la utilización de Arabidopsis thaliana, se abordó también la obtención de plantas de tomate que sobreexpresan la THT1-3. Con la misma construcción que se empleó en Arabidopsis thaliana, se llevó a cabo la transformación genética de tomate mediante cocultivo de explantes de cotiledón. Como resultado de la transformación se obtuvieron 6 líneas de tomate resistentes a kanamicina (líneas 11.1, 11.2, 12.3, 34.1, 35.1 y 38.1). Todos los análisis que se describen a continuación se realizaron sobre plantas $\mathrm{T}_{0}$, tanto en el caso de las transgénicas como en los controles, después de un periodo de un mes de aclimatación en el invernadero. Se realizó la detección de la actividad $\beta$-glucuronidasa in situ en hojas de estas líneas y se observó dicha actividad en todas ellas. Para comprobar que el transgén se estaba sobreexpresando se realizó una purificación de RNA total y una posterior RT-PCR para cada una de las líneas (figura 34). Como control de la PCR se utilizó la proteína ribosomal L2 de tomate (Fleming et al., 1993). Como puede verse en la figura 34 todas las líneas analizadas mostraron expresión constitutiva del gen THT1-3, mientras que no se detectó acumulación de transcrito en las plantas control.

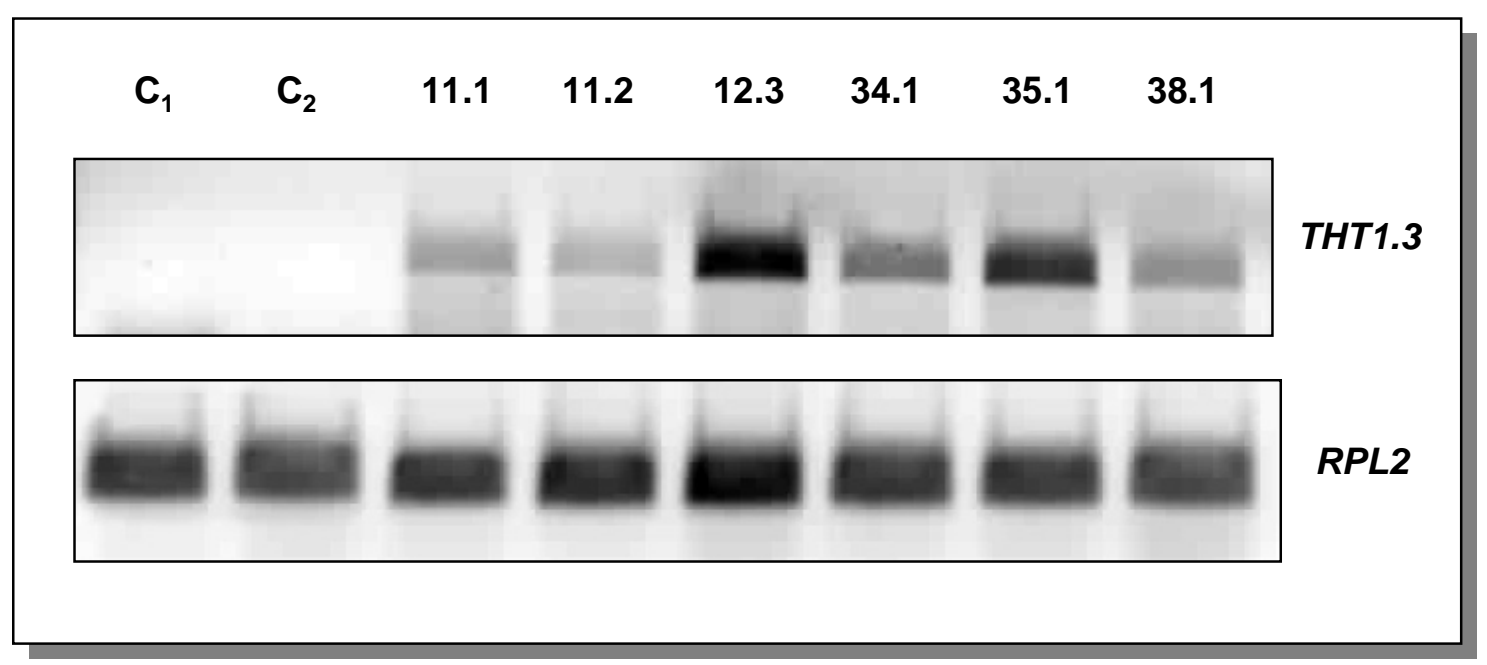

Figura 34. Acumulación del mRNA del isoenzima THT1-3 en las líneas transgénicas de tomate 11.1, 11.2, 12.3, 34.1, 35.1 y 38.1, y en dos controles no transgénicos. Panel superior: PCR realizada con oligonucleótidos específicos del gen THT1-3. Panel inferior: PCR realizada con oligonucleótidos específicos del gen RPL2 (347 bp) utilizado como control para la transcripción reversa. 
IV.6.2.1.- Estudio de la acumulación de HCAAs en plantas 35S2X::THT1-

\section{3::nos de tomate.}

La extracción de compuestos fenólicos y el análisis de los niveles de acumulación de HCAAs en las hojas se llevó a cabo tal y como se describe en el apartado de Materiales y Métodos. Los extractos fueron analizados mediante HPLCMS. En todas las líneas de tomate que sobreexpresan la THT se ha encontrado la acumulación de $p$-cumaroiltiramina, una de las HCAAs (figura 35) que, según nuestros resultados, es inducida por Pseudomonas syringae. Los niveles alcanzados de CT son, superiores a los observados en las plantas no transgénicas (control) y, en algunos casos (líneas 11.2 y 12.3), hasta cinco veces los observados en los controles.

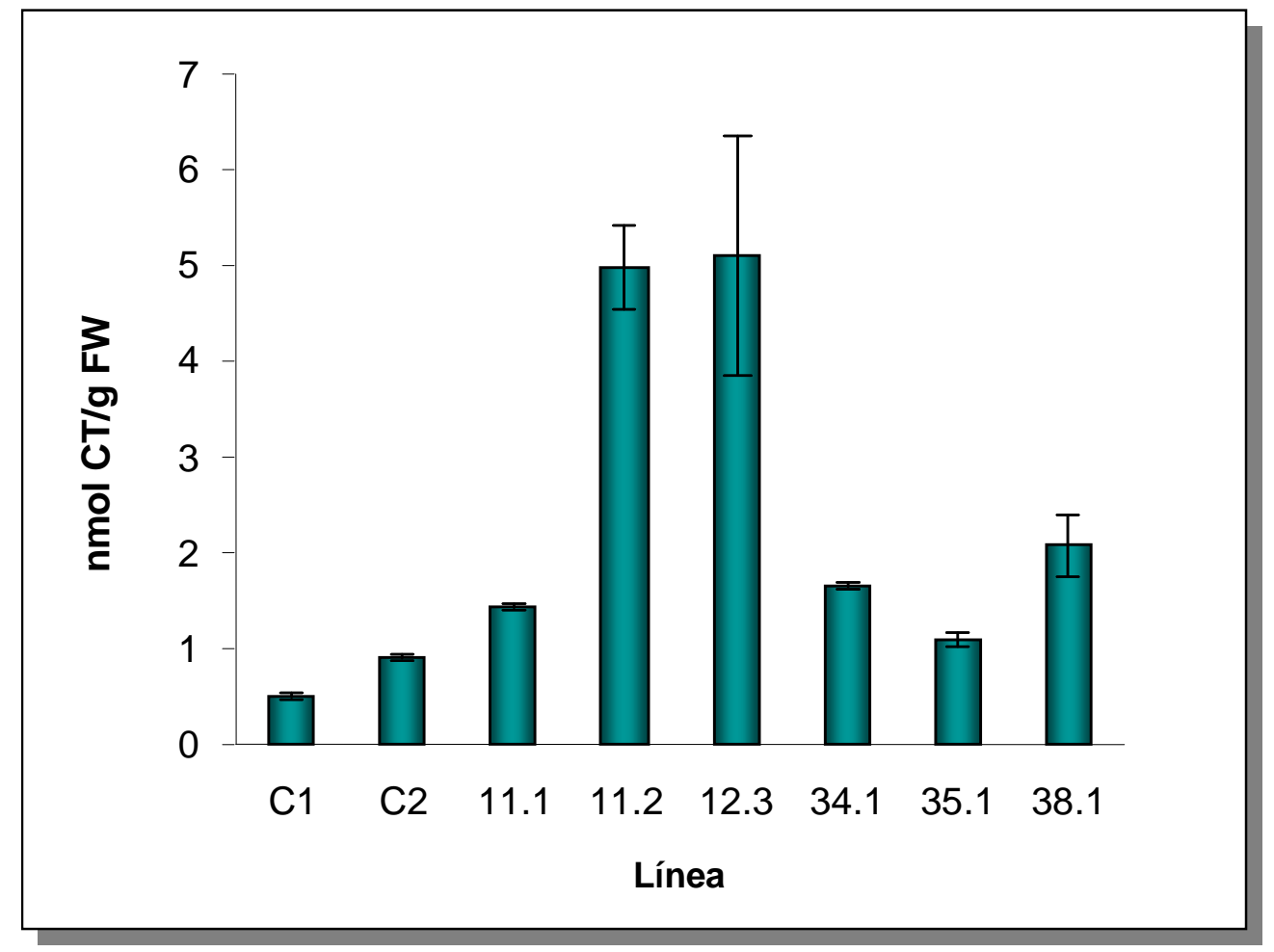

Figura 35. Niveles de acumulación de $p$-cumaroiltiramina en las líneas transgénicas 11.1, 11.2, 12.3, 34.1, 35.1 y 38.1 comparadas con las líneas control (C1 y C2). Los datos que se muestran representan la media de tres medidas independientes calculadas a partir de las áreas obtenidas de un cromatograma en la modalidad de scan en positivo. 
Contrariamente a estos resultados, Hagel y Facchini (2005) obtuvieron plantas transgénicas de tabaco que sobreexpresaban la THT y vieron que la alteración en la actividad de dicho enzima no tenía efecto alguno en la acumulación de HCAAs en plantas transgénicas sanas. Únicamente detectaron niveles significativos de CT y FT en plantas transgénicas sometidas a una reacción de herida. Por su parte, Jang y colaboradores (2004) generaron plantas transgénicas de arroz que sobreexpresaban la SHT (hydroxicinnamoyl-CoA:serotonine $N$-(hidroxicinamoil)transferase), una hidroxicinamoil transferasa, similar a la THT, pero que utiliza como sustrato serotonina en lugar de tiramina. En este caso tampoco se encontraron niveles constitutivos de HCAAs en las plantas transgénicas debido posiblemente a una limitación en la disponibilidad de los sustratos utilizados por la proteína. Sólo en el caso del arroz transgénico que sobreexpresa la THT de forma constitutiva (Lee et al., 2007) se ha encontrado una acumulación diferencial de CT y FT, principalmente asociada a las hojas más jóvenes de la planta. Dicha acumulación, aunque baja, es significativamente mayor a la observada en las plantas control. Además, la aplicación exógena de tiramina a las raíces de dichas plantas transgénicas provoca una aumento en los niveles constitutivos de CT y FT en la hojas, deduciéndose que la síntesis de CT y FT está regulada por la disponibilidad de tiramina en los tejidos. Los autores sugieren que los bajos niveles constitutivos de CT y FT alcanzados en las plantas de arroz transgénicas podrían deberse a una baja disponibilidad de tiramina endógena en estas plantas.

El hecho de que las plantas transgénicas de tomate que hemos obtenido acumulen de forma constitutiva CT invita a proseguir en un futuro en el estudio de la posible implicación del enzima THT y de estas amidas en la interacción de tomate y Pseudomonas syringae pv. tomato. Una vez obtenidas las líneas $\mathrm{T}_{2}$ homocigotas correspondientes se llevarán a cabo los siguientes estudios:

1. Medidas de HCAAs en dichas líneas con el fin de constatar los resultados presentados hasta el momento.

2. Ensayos de resistencia frente a la bacteria Pseudomonas syringae en estas líneas. 
El análisis de nuevas líneas transgénicas obtenidas en la transformación que silencien el gen de la THT y los análisis en dichas líneas de la alteración de la acumulación de las HCAAs y de la resistencia, permitirá completar el estudio de la posible función defensiva de las amidas y de la THT. 
V. Conclusiones 


\section{Conclusiones.}

1. Las plantas de tomate 'Rutgers' infectadas con la bacteria Pseudomonas syringae pv. tomato acumulan cuatro compuestos de naturaleza fenólica, indetectables en extractos de planta sana. Además, dicha acumulación se produce en otras variedades de tomate (Ailsa Craig, Moneymaker y UC82) en respuesta a la bacteria, de forma similar a como ocurre en la variedad 'Rutgers'.

2. Nuestros resultados indican que estos compuestos se encuentran en la planta en forma libre ya que, incubaciones con $\alpha$-glucosidasa, $\beta$-glucosidasa y esterasa de los extractos no producen una mayor acumulación de los mismos.

3. Los cuatro compuestos detectados han sido identificados por HPLC-MS como amidas derivadas del ácido hidroxicinámico (HCAAs) pertenecientes al grupo de los fenilpropanoides: $p$-cumaroildopamina, feruloildopamina, $p$-cumaroiltiramina $\mathrm{y}$ feruloiltiramina. Es la primera vez que se describe la acumulación de $p$ cumaroildopamina y feruloildopamina en respuesta a una infección en plantas.

4. La acumulación de las HCAAs se produce localmente en el entorno de los puntos de infección de la bacteria Pseudomonas syringae pv. tomato, habiéndose observado niveles de acumulación mucho más bajos en el resto de la hoja e indetectables en hojas sistémicas.

5. La acumulación de las cuatro HCAAs, inducidas por Pseudomonas syringae pv. tomato, es independiente de la señalización por ácido salicílico.

6. El aumento de etileno asociado a la infección patogénica constituye una señal necesaria para la inducción, tanto de la THT como de las HCAAs. 
7. De las cuatro amidas inducidas por Pseudomonas syringae pv. tomato sólo las derivadas de la dopamina ( $p$-cumaroildopamina y feruloildopamina) poseen una fuerte actividad antioxidante frente al radical DPPH.

8. La p-cumaroildopamina y la feruloildopamina podrían estar actuando directamente como componentes antimicrobianos de la respuesta defensiva final en tomate por la infección con Pseudomonas syringae pv. tomato, ya que muestran una notable actividad antibacteriana in vitro frente a dicha bacteria.

9. La sobreexpresión del enzima THT de tomate en plantas transgénicas de Arabidopsis thaliana produce la acumulación de un compuesto diferencial que podría corresponderse con una nueva HCAA, la sinapoiltiramina. .

10. La sobreexpresión del enzima THT en plantas transgénicas de tomate produce una acumulación constitutiva de $p$-cumaroiltiramina. Los niveles alcanzados en las líneas transgénicas son, en todos los casos, superiores a los observados en las plantas no transgénicas (control). 
VI. Bibliografía 


\section{Bibliografía.}

Alonso, J.M., Hirayama, T., Roman, G., Nourizadeh, S. and Ecker, J.R. (1999). EIN2, a bifunctional transducer of ethylene and stress responses in Arabidopsis. Science 284: $2148-2152$.

Álvarez, M.E., Penell, R.I., Meijer, P.J., Ishikawa, A., Dixon, R.A., and Lamb, C. (1998). Reactive oxygen intermediates medite a systemic signal network in the establishment of plant immunity. Cell-Cambridge 92: 773-784.

Álvarez, M.E. (2000). Salicylic acid in the machinery of hypersensitive cell death and disease resistance. Plant Mol. Biol. 44: 429-442.

Adams, D.O., and Yang, S.F. (1979). Ethylene biosynthesis: identification of 1aminocyclopropane1-1carboxylic acid as an intermediate in the conversion of methionine to ethylene. Proc. Natl. Acad. Sci. USA 76: 170-174.

Alfaro, C., Urios, A., González, M.C., Moya, P., and Blanco, M. (2003). Screening for metabolites from Penicillium novae-zeelandiae displaying radical-scavening activity and oxidative mutagenicity: isolation of gentisyl alcohol. Mutat. Res. 539: 187-194.

Aribaud, M., and Martin-Tanguy, J. (1994a). Polyamine metabolism, floral induction and floral development in chrysanthemum (Chrysanthemum morifolium Ramat.) Plant Growth Regul. 15: 23-31.

Aribaud, M., and Martin-Tanguy, J. (1994b). Polyamine metabolism in normal and sterile chrysanthemum plants. Phytochemistry 3: 927-932.

Armero, J., and Tena, M. (2001). Posible role of plasma membrane $\mathrm{H}^{+}$-ATPase in the elicitation of phytoalexin and related isoflavone root secretion in chickpea (Cicer arietinum L.) seedlings. Plant Sci. 161: 791-798.

Ausubel FM, Brent R, Kingston RE, Moore DD, Sedman JG, Smith JA y Struhl K (1995). Current Protocols in Molecular Biology. John Wiley \& Sons Inc. Boston. EE.UU. 
Back, K., Jang, S.M., Lee, B.C., Schmidt, A., Strack, D., Kim, K.M. (2001). Cloning and characterization of a hydroxycinnmoyl-CoA:tyramine $N$-(hydroxycinnamoyl) transferase induced in response to UV-C and wounding from Capsicum annuит. Plant Cell Physiol. 42: 475-481.

Baker, C. J., Orlandi, E. W., and Mock, N. M. (1993). Harpin, an elicitor of the hypersensitive response in tobacco caused by Erwinia amylovora, elicits active oxygen production of suspension cells. Plant Physiol. 102: 1341-1344.

Baker, B., Zambryski, P., Staskawicz, B., and Dinesh-Kumar, S. P.(1997). Signaling in plant-microbe interactions. Science 276: 721-733.

Baldwin, I.T., Halitschke, R., Paschold, A., von Dahl, C.C., and Preston, C.A. (2006). Volatile signal in plant-plant interactions: 'talking trees' in the genomic era. Science 311: $812-815$.

Bechtold, N, Ellis, J and Pelletier, G (1993). In planta Agrobacterium-mediated gene transfer by infiltration of adult Arabidopsis thaliana plants. C. R. Acad. Sci. Paris Life Sci. 316: 1194-1199.

Beggs, C.J., Kuhn, K., Böcker, R., and Wellmann, E. (1987). Phytocrome-induced flavonoid biosynthesis in mustard (Sinapis alba L.) cotyledons: Enzymic control and differential regulation of anthocyanin and quercetin formation. Planta 172: 121-126.

Beimen, A., Witte, L., and Barz, W. (1992). Growth characteristics and elicitor-induced reactions of photosynthetically active and heterotrophic cell suspension cultures of Lycopersicon peruvianum (Mill.) Bot. Acta 105: 152-160.

Belicova, A., Krizkova, L., Nagy, M., Krajcovic, J. and Ebringer, L. (2001). Phenolic acids reduce the genotoxicity of acridine orange and ofloxacin in Salmonella typhimurium. Folia Microbiol. (Praha) 46: 511-514.

Bellés, J.M. and Conejero, V. (1989). Evolution of ethylene production, ACC and conjugated ACC levels accompanying symptom development in tomato and gynura aurantiaca DC leaves infected with citrus exocortis viroid (CEVd). J. Phytopathology 127: 81-85.

Bellés, J.M., Granell, A., Durán-Vila, N. and Conejero, V. (1989). ACC synthesis as the activated step responsible for the rise of ethylene production accompanying citrus exocortis viroid infectection in tomato plants. J. Phytopathology 125: 198-208. 
Bellés, J.M., Garro, R., Navarro, P., Primo, J., Conejero, V. (1999). Gentisic acid as a pathogen-inducible signal, additional to salicylic acid for activation of plant defenses in tomato. Mol. Plant Microbe Interact.12 (3): 227-235.

Bellés, J.M., Garro, R., Pallás, V., Fayos, J., Rodrigo, I., and Conejero, V. (2006). Accumulation of gentisic acid as associated with systemic infections but not with the hypersensitive response in plant-pathogen interactions. Planta 223: 500-511.

Bent, A. R. (1996). Plant disease resistance gene: Function meets structure. Plant Cell 8: 757-1771.

Bernards, M.A., López, M.L., Zajicek, J., and Lewis, N.G. (1995). Hydroxycinnamic acid-derived polymers constitute the polyaromatic domain of suberin. J. Biol. Chem. 270: $7382-7386$.

Bevan, M. (1984). Binary Agrobacterium vectors for plant transformation. Nucl. Acids. Res. 12: 8711-8721.

Bleecker, A.B., Estelle, M.A., Sommerville, C., and Kende, H. (1988). Insensitivity to ethylene conferred by a dominant mutation in Arabidopsis thaliana. Science 241:1086-1089.

Boller, T. (1990). Ethylene and plant-pathogen interactions. Pages 138-145 In: Polyamine and Ethylene: Biochemistry, Physiology, and Interactions, H.E. Flores, R.N. Arteca, and J.C. Shannon, eds. American Society of Plant Physiologist, Rockville.

Boller, T. (1991). Ethylene in pathogenesis and disease resistance. In The Plant Hormone Ethylene, ed. AK Mattoo, JC Sutle, pp 293-314. Boca Raton, FL: CRC Press.

Boller, T. (1995). Chemoperception of microbial signals in plant cells. Annu. Rev. Plant Phisiol. Plant Mol. Biol. 46: 189-214.

Bolwell, G.P., and Wojtaszek, P. (1997). Mechanism for generation of reative oxygen sepecies in plant defense: a broad perspective. Physiol. Mol. Plant Pathol. 51: 347366.

Bonneau, L., Carré, M., and Martin-Tanguy, J. (1994). Polyamines and related enzymes in rice differing in germination potential. Plant Growth Regul. 15: 75-82. 
Brading, P. A., Hammomd-Kosack, K. E.; Parr, A., Jones, J. D. G. (2000). Salicylic acid is not required for $C f-2$ and $C f-9$ - dependent resistance of tomato to Cladosporium fulvum. Plant J. 23 (3): 305-318.

Broekaert, W.F., Delauré, S.L., De Bolle, M.F.C., and Cammue, B.P.A. (2006). The role of ethylene in host-pathogen interactions. Annu. Rev. Phytopathol. 44: 393-416.

Browse, J. (2005). Jasmonate: an oxylipin signal with many roles in plants. Vitamins and Hormones 72: 431-456.

Buchanan, B.B., Gruissem, W., and Jones, R.L. (2002). Natural products (secondary metabolites). In: Biochemistry and molecular biology of plants. American Society of Plant Physiologists. pp: 1250-1318.

Cao, H., Bowling, S.A., Gordon, S., Dong, X. (1994). Characterization of an Arabidopsis mutant that is nonresponsive to inducers of systemic acquired resistance. Plant Cell 6: 1583-1592.

Chae, H.S., and Kieber, J.J. (2005). Eto Brute? Role of ACS turnover in regulation ethylene biosynthesis.Trends Plant Sci. 10:291-296.

Chang, C., Kwok, S.F., Bleecker, A.B., and Meyerowitz, E.M. (1993). Arabidopsis response gene ETR1: similarity of product to two-component regulators. Science 262:39-45.

Chao, Q., Rothenberg, M., Solano, R., Roman, G., and Terzaghi, W. (1997). Activation of the ethylene gas response pathway in Arabidopsis by the nuclear protein ETHYLENEINSENSITIVE3 and related proteins. Cell 89:1133-44

Chen, Y.F., Randlett, M.D., Findell, J.L., and Schaller, G.E. (2002). Localization of the ethylene receptor ETR1 to the endoplasmic reticulum of Arabidopsis. J. Biol. Chem. 277:19861-19866.

Chen, H., McCaig, B.C., Melotto, M., He, S.Y., Howe, G.A. (2004). Regulation of plant arginase by wounding, jasmonate, and the phytotoxin coronatine. J. Biol. Chem. 279: 45998-46007.

Chen, Y.F., Etheridge, N., Schaller, G.E. (2005). Ethylene signal transduction. Ann. Bot. 95:901-915. 
Chern, M., Fitzgerald, H.A., Canlas, P.E., Navarre, D.A., and Ronald, P.C. (2005). Overexpression of a rice NPR1 homolog leads to the constitutive activation of the defense response and hypersensitivity to light. Mol. Plant Microbe Interact. 18: 511520.

Chinchilla, D., Bauer, Z., Regenass, M., Boller, T., and Felix, G. (2006). The Arabidopsis receptor kinase FLS2 binds flg22 and determines the specificity of flagellin perception. Plant Cell 18: 465-476.

Christie, P.J., Alfenito, M.R., and Walbot, V. 1994. Impact of low-temperature stress on general phenylpropanoid and anthocyanin pathways: Enhancement of transcript abundance and anthocyanin pigmentation in maize seedlings. Planta 194: 541-549.

Ciardi, J.A., Tieman, D.M., Lund, S.T., Jones, J.B., Stall, R.E., and Klee, H.J. (2000). Response to Xanthomonas compestris pv. vesicatoria in tomato involves regulation of ethylene receptor gene expression. Plant Physiol. 113: 81-92.

Clark, K.L., Larsen, P.B., Wang, X. and Chang, C. (1998). Association of the Arabidopsis CTR1 Raf-like kinase with the ETR1 and ERS ethylene receptors. Proc. Natl. Acad. Sci. U.S.A. 95: 5401-5406.

Clarke, D.D. (1982). The accumulation of cinnamic acid amides in the cell walls of potato tissues as an early response to fungal attack. In Active defense mechanisms in plants. Vol. 37. NATO Advanced Study Institute Series A: Life Sciences. Edited by R.K.S. Wood. Plenum Press, New York. Pp.321-322.

Cohn, J.R., and Martin, G.B. (2005). Pseudomonas syringae pv. tomato type III effectors AvrPto and AvrPtoB promote ethylene-dependent cell death in tomato. Plant J. 44:139-54.

Cole, M.D. (1994). Key antifungal, antibacterial and anti-insect assays, a critical review. Biochem. Syst. Ecol. 22 (8): 837-856.

Collinge, D.B., Kragh, K.M., Mikkelsen, J.D., Nielse, K.K., Rasmussen, U., and Vad, K. (1993). Plant chitinases. Plant Journal 3: 31-40.

Conejero, V., Bellés, J.M., García-Breijo, F., Garro, R., Hernández-Yago, J., Rodrido, I., and Vera, P. (1990). Signaling in Viroid Pathogenesis. Recognition and Response in Plant-Virus Interactions. Springer-Verlad. Heidelberg. RFA: 233-263. 
Conejero, V. and Granell, A. (1986). Stimulation of a viroid-like syndrome and the impairement of viroid infection by silver ions. Physiol. and Molec. Plant Pathol. 29: 317-323.

Conejero, V. (1996). La respuesta defensiva de las plantas y su posible manipulación biotecnológica. En Bitecnología y Agricultura. Fundació Bancaixa.

Conejero, V. (1997). Biotecnología y Agricultura: Las plantas del futuro. Fundació Bancaixa. Pp: 97-119.

Cos, P., Rajan, P., Vedernikova, I., Calomme, M., Pieters, L, Vlietinck, A.J., Augustyns, K., Haemers, A., and Berghe, D.V. (2002). In Vitro antioxidant profile of phenolic acid derivatives. Free Radical Research 36(6): 711-716.

Creelman, R.A. and Mullet, J.E. (1997). Biosynthesis and action of jasmonates in plants. Annu Rev Plant Physiol Plant Mol Biol. 48: 355-381.

Degousee, N., Triantaphylides, C., and Montillet, J.L. (1994). Involvement of oxidative processes in the signaling mechanisms leading to the activation of glyceollin synthesis in soybean (Glycine max.). Plant Physiol. 104: 945-952.

Delaney, T. P., Uknes, S., Vernooij, B., Friedrich, L., Weymann, K., Negrotto, D., Gaffney, T., Gut-Rella, M., Kessmann, H., Ward, E., and Ryals, J. (1994). A central role of salicylic acid in plant disease resistance. Science 266: 1247-1250.

Delaney T.P., Friedrich, L., Ryals, J.A. (1995). Arabidopsis signal transduction mutant defective in chemically and biologically induced resistance. Proc. Natl. Acad. Sci. USA 92: 6602-6606.

Delledonne, M., Xia, Y., Dixon, R.A., and Lamb, C. (1994). Nitric oxide functions as a signal in plant disease resistance. Nature 394: 585-588.

Delker, C., Stenzel, I., Hause, B., Miersch, O., Feussner, I., and Wasternack, C. (2006). Jasmonate biosynthesis in Arabidopsis thaliana - enzymes, products, regulation. Plant Biol. 8: 297-306.

De Luca, V., Marineau, C., Brisson, N. (1989). Molecular cloning and analysis of a cDNA encoding a plant tryptophan decarboxilase: comparison with animal dopa decarbosilase. Proc. Natl. Acad. Sci. USA 86: 2582-2586. 
Dempsey, D.A., Shah, J., and Klessig, D.F. (1999). Salicylic acid and disease resistance in plants. Crit. Rev. Plant Sci. 18: 547-575.

Desender, S., Andrivon, D., and Val, F. (2007). Activation of defence reactions in Solanaceae: where is the specificity? Cellular Microbiology 9: 21-30.

Despres, C., DeLong, C., Glaze, S., Liu, E. and Fobert, P.R. (2000). The Arabidopsis NPR1/NIM1 protein enhances the DNA binding activity of a subgroup of the TGA family of bZIP transcription factors. Plant Cell 12: 279-290.

Devoto, A. and Turner, J.G. (2003). Regulation of jasmonate-mediated plant responses in arabidopsis. Ann. Bot. 92: 329-337.

Devoto, A. and Turner, J.G. (2005). Jasmonate-regulated Arabidopsis stress signalling network. Physiol. plantarum 123: 161-172.

Díaz, J., ten Have, A., and van Kan, J.A.L. (2002). The role of ethylene and wound signaling in resistance of tomato to Botrytis cinerea. Plant Physiol. 129: 1341-1351.

Dicke M, van Beek, T.A., Posthumus, M.A., Ben Dom, N., van Bokhoven, H., de Groot, A.E. (1990). Isolation and identification of volatile kairomone that affects acarine predator-prey interactions-involvement of host plantas in its production. J. Chem. Ecol. 16: 381-396.

Dicke, M, and Bruin, J. (2001). Chemical information transfer between plants: back to the future. Biochem. Syst. Ecol. 29: 981-994.

Dixon, R.A., and Lamb, C.J. (1990). Molecular comunication in interactions between plants and microbial pathogens. Annu. Rev. Plant Physiol. Plant Mol. Biol. 41: 339367.

Dixon, R.A. and Paiva, M.L. 1995. Stress-Induced phenylpropanoid metabolism. Plant Cell 7: 1085-1097.

Dixon, R.A., Harrison, J. J., and Lamb, C. J. (1994). Early events in the activation of plant defense responses. Annu. Rev. Phytopathol. 32: 479-501.

Dixon, R.A. (2001). Natural products and plant disease resistance. Nature 411: 843-847.

Dolmetsch, R.E., Lewis, R.S., Goodnow, C.C., Healy, J.I. (1997). Differential activation of transcription factors induced by $\mathrm{Ca}^{2+}$ response ampliude and duration. Nature 386: 855-858. 
Domingo, C., Conejero, V., y Vera, P. (1994). Genes encoding acidic and basic class III beta-1,3-glucanases are expressed in tomato plants upon viroid infection. Plant Mol. Biol. 24: 725-732.

Durrant, W.E., and Dong, X. (2004). Systemic acquired resistance. Annu. Rev. Phytopathol. 42: 185-209.

Ellis, C., and Turner, J.G. (2001). The Arabidopsis mutant cev1 has constitutively active jasmonate and ethylene signal pathways and enhanced resistance to pathogens. Plant Cell 13:1025-1033.

Ellis, C., Karafyllidis, I. and Turner, J.G. (2002). Constitutive activation of jasmonate signaling in an Arabidopsis mutant correlates with enhanced resistance to Erysiphe cichoracearum, Pseudomonas syringae, and Myzus persicae. Mol. Plant Microbe. Interact. 15: 1025-1030.

Ellul, P., Garcia-Sogo, B., Pineda, B., Ríos, G., Roig, L.A., and Moreno, V. (2003). The ploidy level of transgenic plants Agrobacterium-mediated transformation of tomato cotyledons (Lycopersicon esculentum L.Mill.) is genotype and procedure dependent. Theor. Appl. Genet. 106: 231-238.

Elstner, E. F., and Heupel, A. (1976). Formation of H2O2 by isolated cell walls from horseradish (Armoracia lapathifolia). Planta. 130: 175-180.

Facchini, P. (2001). Alkaloid biosynthesis in plants: biochemistry, cell biology, molecular regulation, and matabolic engineering applications. Annu. Rev. Plant Mol. Biol. 52: 29-66.

Facchini, P., and De Luca, V. (1994). Differential and tissue-specific expression of a gene family for tyrosine/dopa decarboxylase in opium poppy. J. Biol. Chem. 269: 26684-26690.

Facchini, P.J., Johnson, A.G., Poupart, J., De Luca, V. (1996). Uncoupled defense gene expression and antilicrobial alkaloid accumulaction in elicited opium poppy cell cultures. Plant Physiol. 111: 687-697.

Facchini PJ, Yu M, and Penzes-Yost C. (1999). Decreased cell wall digestibility in canola transformed with chimeric tyrosine decarboxylase genes from opium poppy. Plant Physiol. 120(3):653-664. 
Facchini, P.J., Hagel, J., and Zulak, K.G. (2002). Hydroxycinnamic acid amide metabolism: physiology and biochemistry. Can. J. Bot. 80: 577-589.

Fayos, J., Bellés, J.M., López-Gresa, M.P., Primo, J., and Conejero, V. (2006). Induction of gentisic acid 5-O- $\square$-D-xylopyranoside in tomato and cucumber plants infected by different pathogens. Phytochemistry 67: 142-148.

Farmer, M.J., Czernic, P., Michael, A., and Negrel, J. (1999). Identification of cDNA clones encoding hydroxycinnamoyl-CoA:tyramine $N$-hydroxycinnamoyltransferase from tobacco. Eur. J. Biochem. 263: 686-694.

Felix, G., Duran, J.D., Volko, S., and Boller, T. (1999). Plants have a sensitive perception system for the most conserved domain of bacterial flagellin. Plant J. 18: 265-276.

Feng, S., Ma, L., Wang, X., Xie, D., Dinesh-Kumar, S.P., Wei, N. and Deng, X.W. (2003). The COP9 signalosome interacts physically with SCF COI1 and modulates jasmonate responses. Plant Cell 15: 1083-1094.

Feys, B., Benedetti, C.E., Penfold, C.N. and Turner, J.G. (1994). Arabidopsis mutants selected for resistance to the phytotoxin coronatine are male sterile, insensitive to methyl jasmonate, and resistant to a bacterial pathogen. Plant Cell. 6: 751-759.

Feys, B.J., and Parker, J.E. (2000). Interplay of signaling pathways in plant disease resistance. Trends Genet. 16: 449-455.

Feys, B.J., Moisan, L.J., Newman, M.A., and Parker, J.E. (2001). Direct interaction between the Arabidopsis disease resistance signaling proteins, EDS1 and PAD4. EMBO J. 20: 5400-5411.

Fleming AJ, Mandel T, Roth I y Kuhlemeier C (1993). The patterns of gene expression in the tomato shoot apical meristem. Plant Cell 5: 297-309.

Flores, H.E., and Filner, P. (1985). Polyamine catabolism in higher plants: characterization of pyrroline decarboxylase. Plant Growth Regul. 3: 277-291.

Gaffney, T., Friedrich, L., Vernooij, B., Negrotto, D., Nye, G., Uknes, S., Ward, E., Kessmann, H., and Ryals, J. (1993). Requirement of salicylic acid for the induction if the systemic acquired resistance. Science 261: 754-756. 
Gao, Z., Chen, Y.F., Randlett, M.D., Zhao, X.C., Findell- J.L., Kieber, J.J. and Schaller, G.E. (2003). Localization of the Raf-like kinase CTR1 to the endoplasmic reticulum of Arabidopsis through participation in ethylene receptor signaling complexes. J. Biol. Chem. 278: 34725-34732.

García-Breijo, F.J., Garro, R., and Conejero, V. (1990). C7(P32) and C6(P34) PR proteins induced in tomato leaves by citrus exocortis viroid infection are chitinases. Physiol. Mol. Plant Pathol. 36: 249-260.

Gershenzon, J., and Dudareva, N. (2007). The function of terpene natural products in the natural world. Nat. Chem. Biol. 3: 408-414.

Gianinazzi, S., Martin, C., and Vallée. (1970). Hypersensibilité aux virus, température et protéines solubles chez le Nicotiana Xanthi n.c. Apparition de nouvelles macromolécules lors de la répression de la synthèse virale. C.R. Acad. Sci. Paris 270D : 2383-2386.

Glazebrook, J., Rogers, E.E., and Ausubel, F.M. (1996). Isolation of an Arabidopsis mutants with enhanced disease susceptibility by direct screening. Genetics 143: 973982.

Glazebrook, J., Chen, W., Estes, B., Chang, H.S., and Nawrath, C. (2003). Topology of the network integrating salicylate and jasmonate signal transduction derived from global expression phenotyping. Plant J. 34:217-228.

Goddijn, O.J.M., de Kam, R.J., Zanetti, A., Schilperoort, R.A., and Hoge, J.H.C. (1992). Auxin rapidly down-regulates transcription of the tryptophan decarboxylase gene from Catharantus roseus. Plant Mol. Biol. 18: 1113-1120.

Gomez-Gomez, L., and Boller, T. (2002). Flagellin perception: a paradigmfor innate immunity. Trends Plant Sci. 7: 251-256.

Grandmaison, J., Olah, G.M., Van Calsteren, M.R., and Furlan, V. (1993). Characterization and localization of plant phenolics likely involved in the pathogen resistance expressed by endomicorrhyzal roots. Mycorrhyza 3: 155-164.

Granell, A., Bellés, J.M. and Conejero, V. (1987). Induction of pathogenesis-related proteins in tomato by citrus exocortis viroid, silver ion and ethephon. Physiol. Mol. Plant Pathol. 31: 83-90. 
Grant, M., and Lamb, C. (2006). Systemic immunity. Curr. Opin. Plant Biol. 9: 414420.

Guillet, G., Bélanger, A., and Arnason, J.T. (1998). Volatile monoterpenes in Poropyllum gracile and $P$. ruderale (Asteraceae): identification, localization and insecticidal synergism with $\alpha$-terthienyl. Phytochemistry 49: 423-429.

Guillet, G., and De Luca, V. (2005). Wound-inducible biosynthesis of phytoalexin hydroxycinnamic acid amides of tyramine and tryptophan and tyrosine decarbosilase transgenic tobacco lines. Plant Physiol. 137: 692-699.

Guo, Z., Lamb, C., and Dixon, R.A. (1998). Potentiation of oxidative burst and isoflavonoid phytoalexin accumulation by serine protease inhibitors. Plant Physiol. 118: $1487-1494$.

Guo, H., Ecker, J.R. (2004). The ethylene signaling pathway: new insights. Curr. Opin. Plant Biol. 7:40-749.

Hagel JM, and Facchini PJ. (2005). Elevated tyrosine decarboxylase and tyramine hydroxycinnamoyltransferase levels increase wound-induced tyramine-derived hydroxycinnamic acid amide accumulation in transgenic tobacco leaves. Planta 221(6):904-14.

Hagemeier, J., Schneider, B., Oldham, N.J., and Hahlbrock, K. (2001). Accumulation of soluble and cell wall-bound indolic metabolites in Arabidopsis thaliana leaves infected with virulent or avirulent Pseudomonas syringae pv. tomato strains. PNAS 98: 753-758.

Hahlbrock, K., and Scheel, D. (1989). Physiology and moleculaer biology of phenylpropanoid metabolism. Annu. Rev. Plant Physiol. Plant Mol. Biol. 40: 347369.

Halitschke, R., and Baldwin, I.T. (2004). Jasmonates and related compounds in plant insect interactions. J. Plant Growth Regul. 23: 238-245.

Hammond-Kosack, K.E. and Parker, J.E. (2003). Deciphering plant-pathogen communication: fresh perspectives for molecular resistance breeding. Curr. Opin. Biotechnol. 14:177-93.

Hanahan, D. (1986). Studies on transformation of Escherichia coli with plasmids. J. Mol. Biol. 166: 557-580. 
Harborne, J.B. (1980). Plant phenolics. Pages 329-402 in: Secondary Plant Products, New Series, Vol. 8. E.A. Bell, and B.V. Charlwood, eds. Springer, New York.

Harkin, J. M., and Obst, J. R. (1973). Lignification in trees: indication of exclusive peroxidase participation. Science. 180: 266-298.

Heil, M., and Bueno, J.C.S. (2007). Within-plant signalling by volatiles leads to induction and priming of an indirect of plant defense in nature. Proc. Natl. Acad. Sci. USA 104: 5467-5472.

Hibi, N., Higashiguchi, S., Hashimoto, T., and Yamada, Y. (1994). Gene expression in tobacco low-nicotine mutants. Plant Cell 6: 723-735.

Hilpert, B., Bohlmann, H., op den Camp, R.O., Przybyla, D., Miersch, O., Buchala, A. and Apel, K. (2001). Isolation and characterization of signal transduction mutants of Arabidopsis thaliana that constitutively activate the octadecanoid pathway and form necrotic microlesions. Plant J. 26: 435-446.

Hirota, A., Morimitsu, Y., and Hojo, H. (2000). New antioxidative indophenol-reducing phenol compounds isolated from Mortierella sp. Fungus. Biosci. Biotech. Biochem. 64: 1038-1040.

Hoffman, L., Besseau, S., Geoffroy, P., Ritzenthaler, C., Meyer, D., Lapierre, C., Pollet, B., and Legrand, M. (2004). Silencing of hydroxicinnamoyl-coenzyme A shikimate/quinate hydroxycinnamoyltransferase affects phenylpropanoid biosynthesis. Plant Cell 16: 1446-1465.

Howe, G.A. (2004). Jasmonates as signals in the wound response. J. Plant Growth Regul. 23: 223-237.

Hua, J., Chang, C., Sun, Q., Meyerowitz, E.M. (1995). Ethylene insensitivity conferred by Arabidopsis ERS gene. Science 269:1712-1714.

Hua, J., Meyerowitz, E.M. (1998). Ethylene responses are negatively regulated by a receptor gene family in Arabidopsis thaliana. Cell 94:261-271.

Hua, J., Sakai, H., Nourizadeh, S., Chen, Q.G., and Bleecker, A.B. (1998). EIN4 and ERS2 are members of the putative ethylene receptor gene family in Arabidopsis. Plant Cell 10:1321-1332. 
Hückelhoven, R. (2007). Cell wall-associated mechanisms of disease resistance and susceptibility. Annu. Rev. Phytopathol. 45: 2.1-2.27.

Hummerschmidt, R. (1999). Phytoalexins: what have we learned after 60 years? Ann. Rev. Phytopayhol. 37: 285-306.

Iiyama K, Lam T, and Stone BA. (1994). Covalent Cross-Links in the Cell Wall. Plant Physiol. 104(2):315-320.

Ishihara, A., Kawata, N., Matsukawa, T., Iwamura, H. (2000). Induction of $N$ hydroxycinnamoyltyramina synthesis and $N$-hydroxycinnamoyltransferase (THT) activity by wounding in maize leaves. Biosci. Biotechnol. Biochem. 64: 1025-1031.

Jabs, T., Tschöpe, M., Colling, C., Hahlbrock, K., and Scheel, D. (1997). Elicitorstimulated ion fluxes and $\mathrm{O}_{2}^{-}$from the oxidative burst are essential components in triggering defense gene activation and phytoalexin synthesis in parsley. Proc. Natl. Acad. Sci. U.S.A. 94: 4800-4805.

Jang S.M., Ishihara A., and Back K. (2004). Production of coumaroylserotonin and feruloylserotonin in transgenic rice expressing pepper hydroxycinnamoyl-coenzyme A:serotonin N-(hydroxycinnamoyl)transferase. Plant Physiol. 135(1):346-56.

Jirage, D., Tootle, T.L., Reuber, T.L., Frost, L.N., Feys, B.J., Parker, J.E., Ausubel, F.M., and Glazebrook, J. (1999). Arabidopsis thaliana PAD4 encodes a lipase-like gene that is important for salicylic acid signaling. Proc. Natl. Acad. Sci. USA 96: 13583-13588.

Jones, J.D.G., and Dangl, J. (2006). The plant immune system. Nature 444:323-329.

Kang, R., Helms, R., Stout, M.J., Jaber, H., Chen, Z., and Nakatsu, T. (1992). Antimicrobial activity of the volatile constituents of Perilla fluorescens and its synergistic effects with polygodial. J. Agric. Food Chem. 40: 2328-2330.

Kanikkannan, N., Kandimalla, K., Lamba, S.S., and Singh, M. (2000). Structure-activity relationship of chemical penetration anhances in transdermal drug delivery. Curr. Med. Chem. 7: 593-608.

Kappers, I.F., Aharoni, A., van Herpen, T.W., Luckerhoff, L.L., Dicke, M., and Bouwmeester, H.J. (2005). Genetic engineering of terpenoids metabolism attracts bodyguards to Arabidopsis. Science 309: 2070-2072. 
Kauss, H., Franke, R., Krause, K., Conrath, U., Jeblick, W., Griming, B., and Matern, U. (1993). Conditioning of Parsley (Petroselinum crispum L.) Suspension Cells Increases Elicitor-Induced Incorporation of Cell Wall Phenolics. Plant Physiol. 102: 459-466.

Kawalleck, P., Keller, H., Hahlbrock, K., Scheel, D., and Somssich, I.E. (1993). A pathogen-responsive gene of parsley encodes tyrosine decarboxylase. J. Biol. Chem. 268: 2189-2194.

Kawano, T. (2003). Roles of the reative oxygen species-generating peroxidase reactions in plant defense and growth induction. Palnt Cell Rep. 21: 829-837.

Keller, H., Hohlfeld, H., Wray, V., Hahlbrock, K, Scheel, D., and Strack, D. (1996). Changes in the accumulation of soluble and cell wall-bound phenolics in elicitortreated cell suspension cultures and fungus-infected leaves of Solanum tuberosum. Phytochemistry 42: 389-396.

Kessler, A., and Baldwin, I.T. (2001). Defensive function of herbivore-induced plant volatile emissions in nature. Science 291: 2141-2144.

Kikuzaki, H., Hisamoto, M., Hirose, K., Akiyama, K., and Tanigughi, H. (2002). Antioxidant properties of ferulic acid and its related compounds. J. Agric. Food Chem. 50: 2161-2168.

Kinkema, M., Fan, W., and Dong, X. (2000). Nuclear localization of NPR1 is required for activation of $P R$ gene expression. Palnt Cell 12: 2339-2350.

Kloek, A.P., Verbsky, M.L., Sharma, S.B., Schoelz, J.E., Vogel, J., Klessig, D.F. and Kunkel, B.N. (2001). Resistance to Pseudomonas syringae conferred by an Arabidopsis thaliana coronatine-insensitive (coi1) mutation occurs through two distinct mechanisms. Plant J. 26: 509-522.

Korkina, L.G. (2007). Phenylpropanoids as naturally ocurring antioxidants: from plant defense to human health. Cell. Mol. Biol. 53: 13-23.

Laks, P.E. and Pruner, M.. (1989). Flavonoid Biocides: Structure/Activity Relations of Flavonoid Phytoalexin Analogues Phytochemistry 28: 87.

Lamb, C., and Dixon, R.A. (1997). The oxidative burst in plant disease resistance. Annu. Rev. Plant Physiol. Plant Mol. Biol. 48: 251-275. 
Lattanzio, V., De Cicco, D., Venere, D., Lima, G. and Salerno, M. (1994). Antifungal activity of phenolics against fungi commonly encountered during storage. Ital. J. Food Sci. 6: 23-30.

Lapous, D., Mathieu, Y., Guern, J., and Lauriere, G. (1998). Increase of defense gene transcripts by citoplasmic acidification in tobacco cell suspension cultures. Planta 205: 452-458.

Lecorieux, D., Mazars, C., Pauly, N., Ranjeva, R. Pugin, A. (2002). Analysis and effects of cytosolic free calcium increases in response to elicitors in Nicotiana plumbaginifolia cells. Plant Cell 14: 2627-2641.

Lee, D.E., Kiyoon, K., Seong-Gene, L., Kyoungwhan, B. (2007). Enhanced synthesis of feruloyltyramine and 4-coumaroyltyramine is associated with tyramine availability in transgenic rice expressing pepper tyramine N-hydroxycinnamoyltransferase. Plant Sci. 172(1): 57-63.

Levine, A., Tenhaken, R, Dixon, R.A., and Lamb, C. (1994). $\mathrm{H}_{2} \mathrm{O}_{2}$ from the oxidative burst orchestrates the plant hypersensitive disease resistance response. Cell 79: 583593.

Li, X., Zhang, Y., Clarke, J.D., Li, Y. and Dong, X. (1999). Identification and cloning of a negative regulator of systemic acquired resistance, SNI1, through a screen for suppressors of npr1-1. Cell 98:329-339.

Li, X., Clarke, J.D., Zhang, Y. and Dong, X. (2001). Activation of an EDS1-mediated Rgene pathway in the snc1 mutant leads to constitutive, NPR1-independent pathogen resistance. Mol. Plant Microbe. Interact. 14:1131-1139.

López-Meyer, M., and Nessler, C.L. (1997). Tryptophan decarboxylase is encoded by two autonomously regulated genes in Campotheca acuminata which are diferentially expressed during develoment and stress. Plant J. 11: 1667-1675.

Lorenzo, O., and Solano, R. (2005). Molecular players regulating the jasmonate signaling network. Curr. Opin. Plant Biol. 8: 532-540.

Lorrain, S., Vailleau, F., Balague, C., and Roby, D. (2003). Lesion mimic mutants : keys for deciphering cell death and defense pathways in plants? Trends Plant Sci. 8: 263271. 
Low, P. S., and Merida, J. R. (1996). The oxidative burst in plant defense: Function and signal transduction. Physiologia Plantarum. 96: 533-542.

Luijendijk, T.J.C., Vnadermeijden, E., Verpoorte, R. (1996). Involvement of strictisidine as a defensive chemical in Catharanthus roseus. J. Chem. Ecol. 22: 1355-1366.

Lund, S.T., Stall, R.E., and Klee, H.J. (1998). Ethylene regulates the susceptible response to pathogen infection in tomato. Plant Cell 10: 371-382.

Lutwak-Mann, C. (1943). The excretion of a metabolic product of salicylic acid. Biochem. J. 37: 246.

Lyons, P.C., Wood, K.V. and Nicholson, R.L. (1990). Caffeoyl ester accumulation in corn leaves inoculated with fungal pathogens. Phytochemistry 29: 97-101.

Maher, E.A., Bate, N.J., Ni, W. Elkind, Y., Dixon, R.A. and Lamb, C.J. (1994). Increased disease susceptibility of transgenic tobacco plants with suppressed levels of preformed phenylpropanoid products. Proc. Natl. Acad. Sci. U.S.A. 91: 78027806.

Marco, J.A. (2006). Terpenos. In: Química de los productos naturales. Ed. Síntesis. pp: 172-233.

Marqués, I.A., and Brodelius, P.E. (1988). Elicitor induced L-tyrosine decarboxilase from plant cell suspension cultures: I. Inductiion and purification. Plant Physiol. 88: 47-51.

Martin, G.B., Brommonschenkel, S.H., Chunwongse, J., Frary, A., Ganal, M.W., Spivey, R., Wu, T., Earle, E.D., and Tanksley, S.D. (1993). Map-Based Cloning of a Protein Kinase Gene Coferring Disease Resistance in Tomato. Science 262: 1432-1436.

Martin-Tanguy, J. (1985). The occurrence and possible function of hidroxicinnamoyl acid amides in plants. Plant Growth Regul. 3: 381-399.

Martin-Tanguy, J. (1997). Conjugated polyamines and reproductive development: Biochemical, molecular and physiological approaches. Physiol. Plant. 100: 675-688.

Matamoros, M.A., Dalton, D.A., Ramos, J., Clemente, M.R., Rubio, M.C., and Becana, M. (2003). Biochemistry and molecular biology of antioxidants in the Rhizobialegume simbiosis. Plant Physiol. 133: 499-509. 
Matsuda, F., Miyagawa, H., and Ueno, T. (2001). Involvement of reactive oxygen species in the induction of $(S)-N$-p-coumaroyloctopamine accumulation by $\beta-1,3-$ glucoologosaccharide elicitors in potato tuber tissues. J. Biosci. 56: 228-234.

Mauch, F., Hadwiger, L.A., and Boller, T. (1984). Ethylene: symptom, not signal for the induction of chitinase and $\beta$-1,3-glucanase in pea pods by pathogens and elicitor. Plant Physiol. 76:607-11

Mauch, F., Mauch-Mani, B., Gaille, C., Kull, B., Haas, D., and Reimmann, C. (1995). Manipulation of salicylate content in Arabidopsis thaliana by the expression of an engineered bacterial salicylate synthase. Plant J. 25: 62-77.

Mayda, E., Mauch-Mani, B., and Vera, P. (2000). Arabidopsis $d t h 9$ mutation identifies a gene involved in regulating disease susceptibility without affecting salicylic acid dependent responses. Plant Cell 12: 2119-2128.

McLusky, S.R., Bennett, M.H., Beale, M.H., Lewis, M.J., Gaskin, P., and Mansfield, J.W. (1999). Cell wall alterations and loccalized accumulation of feruloyl-3'methoxytyramine in onion epidermis al sites of attempted penetration by Botrytis allii are associated with actin polarisation, peroxidase activity and suppression of flavonoid biosynthesis. Plant J. 17: 523-534.

Métraux, J.P., and Raskin, I. (1993). Role of phenolics in plant disease resistance. Pages 191-209 in: Biotechnology in Plant Disease Control. Wiley-Liss, New York.

Mou, Z., Fan, W., Dong, X. (2003). Inducers of plant systemic acquired resistance regulates NPR1 function throught redox changes. Cell 113: 935-944.

Mur, L. A. J., Bi, Y. -M., Darby, R. M., Firek, S., and Draper, J. (1997). Compromising early salicylic acid accumulation delays the hypersensitive response and increases viral dispersal during lesion establishment in TMV infected tobacco. Plant J. 12: 1113-1126.

Naranjo, M.A., Romero, C., Bellés, J.M., Montesinos, C., Vicente, O., and Serrano, R. (2003). Lithium treatement induces a hypersensitive-like response in tobacco. Planta 217: 417-424.

Narvaez-Vazquez, J., Florin-Christensen, J. and Ryan, C.A. (1999). Positional specificity of a phospholipase A activity induced by wounding, systemin, and oligosaccharide elicitors in tomato leaves. Plant Cell. 11: 2249-2260. 
Nawrath, C., and Métraux, J.P. (1999). Salicylic acid induction-deficient mutants of Arabidopsis espress $P R-2$ and $P R-5$ and accumulate high levels of camalexin after pathogen induction. Plant Cell 11: 1393-1404.

Nawrath, C., Heck, S., Parinthawong, N., and Métraux, J.P. (2002). EDS5, an essential component of salicylic acid-dependent signaling for disease resistance in Arabidopsis, is a member of the MATE transporter family. Plant Cell 14: 275-286.

Negrel, J., Brigitte, P., and Lapierre, C. (1996). Ether-linked ferulic acid amides in natural and wound periderms of potato tuber. Phytochemistry 43(6): 1195-1199.

Negrel J, and Lherminier J. (1987). Peroxidase-mediated integration of tyramine into xylem cell walls of tobacco leaves. Planta 172:494-501.

Negrel, J., and Martin, C. (1984). The biosynthesis of feruloyltyramine in Nicotiana tabacum Phytochemistry 23: 2797-2801.

Negrel, J., and Javelle, F. (1997). Purification, characterization, and partial amino acid sequencing of hydroxycinnamoyl-CoA:tyramine N-(hydroxycinnamoyl)transferase from tobacco cell-suspension cultures. Eur. J. Biochem. 247: 1127-1135.

Negrel, J., Javelle, F., and Paynot, M. (1993a). Wound-induced tyramine hydroxycinnamoyl transferase in potato (Solanum tuberosum) tuber discs. J. Plant Physiol. 142: 518-524.

Negrel, J., Javelle, F., and Paynot, M. (1993b). Biochemical basis of resistance of tobacco callus tissue cultures to hydroxyphenylethylamines. Plant Physiol. 103: 329-334.

Negrel, J., Lotfy, S., and Javelle, F. (1995). Modulation of the activity of two hydroxycinnamoyltransferases in wound-healing potato tuber discs in response to pectinase and abscisic acid. J. Plant Physiol. 146: 318-322.

Newman, M.A., von Roepenack-Lahaye, E., Parr, A., Daniels, M.J., and Dow, J.M. (2001). Induction of hydroxicinnamoyl-tyramine conjugates in pepper by Xanthomonas campestris, a plant defense response activated by $h p$ gene-dependent and $h p$ gene-independent mechanisms. Mol. Plant-Microbe Interact. 14: 785-792. 
Niehl, A., Lacomme, C., Erban, A., Kopka, J, Krämer, U., and Fisahn, J. (2006). Systemic Potato virus $X$ infection induces defence gene expression and accumulaction of $\beta$-phenylethylamine-alkaloids in potato. Functional Plant Biology 33: 593-604.

Niggeweg, R., Michael, A.J., and Martin, C. (2004). Engineering plants with increased levels of the antioxidant chlorogenic acid. Nat. Biotechnol. 22: 746-754.

Nimchuk, Z., Eulgem, T., Holt, B.F. III, and Dangl, J.L. (2003). Recognition and response in the plant immune system. Annu. Rev. Genet. 37:579-609.

Norman-Setterblad, C., Vidal, S. and Palva, E.T. (2000). Interacting signal pathways control defense gene expression in Arabidopsis in response to cell wall-degrading enzymes from Erwinia carotovora. Mol. Plant Microbe. Interact. 13: 430-438.

Nurnberger, T., Brunner, F., Kemmerling, B., and Piater, L. (2004). Innate immunity in plants and animals: striking similarities and obvious differences. Immunol. Rev. 198:249-66.

O’Donnell, P.J., Schemelz, E:A., Moussatche, P., Lund, S.T., Jones, J.B., and Klee, H.J. (2003). Susceptible to intolerance - a range of hormonal actions in a suscetible Arabidopsis pathogen response. Plant J. 33: 245-257.

Olson, P. D., and Varner, J. E. (1996). Hydrogen peroxide and lignification. Plant J. 4: 887-892.

Park S.U., and Facchini P.J. (2000). Agrobacterium rhizogenes-mediated transformation of opium poppy, Papaver somniferum 1., and California poppy, Eschscholzia californica cham., root cultures. J Exp Bot. 51(347):1005-1016.

Paynot, M., Perennec, P., Martin, C., Martin-Tanguy, J., Vernoy, R., and Javelle, F. (1983). Photopériodisme, tubérisation et phénolamides. C.R. Acad. Sci. Paris 297 : 87-90.

Pearce, G., Marchand, P.A., Griswold, J., Lewis, N.G., and Ryan, C.A. (1998). Accumulation of feruloyltyramine and p-cumaroyltyramine in tomato leaves in response to wounding. Phytochemistry 47: 659-664.

Penell, R.I., and Lamb, C. (1997). Programed cell death in plants. Plant Cell 9: 11571168. 
Penninckx, I.A., Eggermont, K., Terras, F.R., Thomma, B.P., De Samblanx, G.W., Buchala, A., Metraux, J.P., Manners, J.M. and Broekaert, W.F. (1996). Pathogeninduced systemic activation of a plant defensin gene in Arabidopsis follows a salicylic acid-independent pathway. Plant Cell 8: 2309-2323.

Penninckx, I.A., Thomma, B.P., Buchala, A., Metraux, J.P., and Broekaert, W.F. (1998). Concomitant activation of jasmonate and ethylene response pathways is required for induction of a plant defensin gene in Arabidopsis. Plant Cell 10:21032113

Perrone, S.T., McDonald, K.L., Sutherland, M.W., and Guest, D.I. (2003). Superoxide release is necessary for phytoalexin accumulation in Nicotiana tabaccum cells during the expression of cultivar-race and non-host resistance towards Phytophtora spp. Physiol.Mol. Plant Pathol. 62: 127-135.

Pieterse, C.M., van Wees, S.C., van Pelt, J.A., Knoester, M., Laan, R., Gerrits, H., Weisbeek, P.J. and van Loon, L.C. (1998). A novel signaling pathway controlling induced systemic resistance in Arabidopsis. Plant Cell 10: 1571-1580.

Pieterse, C.M. and van Loon, L.C. (1999). Salicylic acid-independent plant defense pathways. Trends Plant Sci. 4: 52-58.

Pieterse, C.M.J., Ton, J., and Van Loon, L.C. 2001. Cross-talk between plant defence signalling pathways: boost or burden?. AgBiotech Net. 3 .

Pieterse, C.M.J., Schaller, A., Mauch-Mani, B., Conrath, U. (2006). Signaling in plant resistance responses: divergence and coss-talk of defense pathways. In: Tuzun S., Bent E., eds. , multigenic and induced sistemic resistance in plants. New York: Springer, 166-196.

Price, A.H., Taylor, A., Ripley, S.J., Griffiths, A., Tewavas, A.J. and Knight, M.R. (1994). Oxidative signals in tobacco increase cytosolic calcium. Plant Cell 6: 13011310.

Prober JM, Trainor GL, Dam RJ, Hobbs FW, Robertson CW, Zagursky RJ, Cocuzza AJ, Jensen MA y Baumeister K (1987). A system for rapid DNA sequencing with fluorescent chain-terminating dideoxynucleotides. Science. 238: 336-341. 
Reinhardt, D., Wiemken, A., and Boller, T. (1991). Induction of ethylene biosynthesis in compatible and incompatible interactions of soybean roots with Phytophthora megasperma f.sp. glycinea and its relation to phytoalexin accumulation. J. Plant Physiol. 138: 394-399.

Reymond, P. and Farmer, E.E. (1998). Jasmonate and salicylate as global signals for defense gene expression. Curr. Opin. Plant. Biol. 1: 404-411.

Roberts, S.C. (2007). Production and engineering of terpenoids in plant cell culture. Nat. Chem. Biol. 3: 387-395.

Rodrigo, I., Vera, P., Tornero, P., Hernández-Yago, J., and Conejero, V. (1993). cDNA cloning of viroid-induced tomato pathogenesis-relared protein P23. Characterization as a vacuolar antifungal factor. Plant Physiol. 102: 939-945.

Rodriguez, F.I., Esch, J.J., Hall, A.E., Binder, B.M., and Schaller, G.E. (1999). A copper cofactor for the ethylene receptor ETR1 from Arabidopsis. Science 283:996-998

Romero-Puertas, M.C., Perazzolli, M., Zago, E.D., and Delledonne, M. (2004). Nitric oxide signallingfunctions in plant-pathogen interactions. Cell Microbiol. 6: 795-803.

Ross, A.F. (1961). Systemic acquired resistance induced by localized virus infections in plants. Virology 14: 340-358.

Ross, A.F., and Williamson, C.E. (1951). Physiologically active emanations from virusinfected plants. Phytopathology 41:431-438.

Ryals, J. A., Neuenschwander, U. H., Willits, M. G., Molina, A., Steiner, H.-Y., and Hunt, M. D. (1996). Systemic acquired resistance. Plant Cell 8: 1809-1819.

Sakai, H., Hua, J., Chen, Q.G., Chang, C., and Medrano, L.J. (1998). ETR2 is an ETR1like gene involved in ethylene signalling in Arabidopsis. Proc. Natl. Acad. Sci. USA 95:5812-5817.

Sambrook J, Fritsch EF y Maniatis T (1989). Molecular Cloning: a laboratory manual. Cold Spring Harbor Laboratory Press.

Schaller, G.E., and Bleecker, A.B. (1995). Ethylene-binding sites generated in yeast expressing the Arabidopsis ETR1 gene. Science 270:1809-1811.

Schaller, F. (2001). Enzymes of the biosynthesis of octadecanoid-derived signalling molecules. J. Exp. Bot. 52: 11-23. 
Schenk, P.M., Kazan, K., Wilson, I., Anderson, J.P., and Richmon, T. (2000). Coordinated plant defense responses in Arabidopsis revealed by microarray analysis. Proc. Natl. Acad. Sci. USA 97: 11655-11660.

Schmidt, A., Grimm, R., Schmidt, J., Scheel, D., Strack, D., and Rosahl, S. (1999). Cloning and expression of potato cDNA encoding hydroxycinnamoyl-CoA:tyramine $N$-(hydroxycinnamoyl)transferase. J. Biol. Chem. 274: 4273-4280.

Schnee, C., Köllner TG, Held M, Turlings TC, Gershenzon J, Degenhardt J. (2006). The products of a single maize sesquiterpene synthase form a volatile defense signal that attracts natural enemies of maize herbivores. Proc. Natl. Acad. Sci. USA 103: 11291134.

Sembdner, G., and Parthier, B. (1993). The biochemistry and the physiological and molecular action of jasmonates. Annu. Rev. Plant Physiol. Plant Mol. Biol. 44: 569589.

Seo, H.S., Song, J.T., Cheong, J.J., Lee, Y.H., Lee, Y.W., Hwang, I., Lee, J.S., and Choi, Y.D. (2001). Jasmonic acid carboxil methyltransferase: A key enzime for jasmonate regulated plant responses. Proc. Natl. Acad. Sci. USA 98: 4788-4793.

Serino, L., Reimmann, C., Baur, H., Beyeler, M., Visca, P., and Haas, D. (1995) Structural genes for salicylate biosynthesis from chorismate in Pseudomonas aeruginosa. Mol. Gen. Genet. 249: 217-228.

Shah, J., Tsui, F., and Klessig, D.F. (1997). Characterization of a salicylic acidinsensitive mutant (sail) of Arabidopsis thaliana identified in a selective screen utilizing the SA-inducible expression of the tms 2 gene. Mol. Plant Microbe Interact. 10: 69-78.

Shah, J., and Klessig, D.F. (1999). Salicylic acid: signal percepcion and transduction. In Biochemistry and Molecular Biology of Plant Hormones, ed. PPJ Hooykaas, MA Hall, KR Libbenga, pp. 513-541. London: Elsevier.

Shah, J., Kachroo, P., Nandi, A. and Klessig, D.F. (2001). A recessive mutation in the Arabidopsis SSI2 gene confers SA- and NPR1-independent expression of PR genes and resistance against bacterial and oomycete pathogens. Plant J. 25: 563-574.

Shah, J. (2003). The salicylic acid loop in plant desense. Curr. Opin. Plant Biol. 6: 365367. 
Shakano, K. (2001). Metabolic regulation of $\mathrm{pH}$ in defense reaction in plant cells: rolle of cytoplasmic $\mathrm{pH}$ in defense reaction and seconsary metabolism. Int. Rev. Cytol. 206: 1-44.

Smith, C.J. (1994). Signal transduction in elicitation of phytoalexin synthesis. Biochem. Soc. Trans. 22: 414-419.

Spoel, S.H., Koornneef, A., Claessens, S.M.C., Korzelius, J.P., and Van Pelt, J.A. (2003). NPR1 modulates cross-talk between salicylate- and jasmonate-dependent defense pathways throught a novel function in the cytosol. Plant Cell 15: 760.770.

Staal, J., and Dixelius, C. (2007). Tracing the ancient origins of plant innate immunity. Trends Plant Sci. 12: 334-342.

Staswick, P.E., Tiryaki, I. and Rowe, M.L. (2002). Jasmonate response locus JAR1 and several related Arabidopsis genes encode enzymes of the firefly luciferase superfamily that show activity on jasmonic, salicylic, and indole-3-acetic acids in an assay for adenylation. Plant Cell. 14: 1405-1415.

Staswick, P., and Tyriaki, I. (2004). The oxylipin signal jasmonic acid is activated by an enzyme that conjugates it to isoleucine in Arabidopsis. Plant Cell 16: 2117-2127.

Stepanova, A.N., and Alonso, J.M. (2005). Ethylene signaling pathway. Sci. STKEI: $\mathrm{cm} 3$.

Sticher, L, Mauch-Mani, B., and Métraux, J.P. (1997). Systemic acquired resistance. Annu. Rev. Phytopathol. 35: 235-270.

Stintzi, A., Weber, H., Reymond, P., Browse, J., and Farmer, E.E. (2001). Plant defense in the absence of jasmonic acid: The role of cyclopentenones. Proc. Natl. Acad. Sci. USA 98: 12837-12842.

Strassner, J., Schaller, F., Frick, U.B., Howe, G.A., Weiler, E.W., Amrhein, N., Macheroux, P. and Schaller, A. (2002). Characterization and cDNA-microarray expression analysis of 12-oxophytodienoate reductases reveals differential roles for octadecanoid biosynthesis in the local versus the systemic wound response. Plant J. 32: 585-601. 
Sun, L.Y., Monneuse, M.O., Martin-Tanguy, J., and Tepfer, D. (1991). Changes in flowering and accumulation of polyamine and hydroxycinnamic acid conjugates in tobacco plants transformed by the rolA locus from the Ri TL-DNA of Agrobacterium rhizogenes. Plant Sci. 80: 145-146.

Sun, W., Dunning, F.M., Pfund, C., Weingarten, R., and Bent, A.F. (2006). Withinspecies flagellin polymorfism in Xanthomonas campestris pv. campestris and its impact on elicitation of Arabidopsis FLAGELIN SENSING2-dependent defenses. Plant Cell 18: 764-779.

Suzuki, T., Holden, I., and Casida, J.E. (1981). Diphenyl ether herbicides remarkably elevate the content of Spinacia oleracea of ( \pm )-3-(4-hydroxy-3-metoxyphenyl)- $N$ (2-(4-hydroxy-3-methylphenyl)ethyl)-2-propenamides. J. Agric. Food Chem. 29: 992-995.

Tanaka, H., Takeshi, N., Kazuhiko, I., and Kazuo, I. (1989). A phenolic amide from Actinodaphne longifolia. Phytochemistry 28 (9): 2516-2517.

Tanaka, E., Tanaka, C., Mori, N., Kuwahara, Y., and Tsuda, M. (2003). Phenylpropanoid amides of serotonin accumulate in witches' broom diseased bamboo. Phytochem. 64: 965-969.

Tarenghi, E., and Martin-Tanguy, J. (1995). Polyamines, floral onduction and floral development of strawberry (Fragaria ananassa Duch.). Plant Growth Regul. 17: 157-165.

Thomma, B.P.H.J., Penninckx, I.A.M.A, Broekaert, W.F., and Cammue, B.P.A.(2001). The complexity of disease signaling in Arabidopsis. Curr. Opin. Immunol. 13: 63-68.

Ton, J., van Pelt, J.A., van Loon, L.C., Pieterse, C.M.J. (2002). Differential effectiveness of salicylate-dependent and jasmonate/ethylene-dependent induced resistance in Arabidopsis. Mol. Plant Micro-Interact. 15:27-34.

Ton, J., D'Alessandro, M., Jourdie, V., Jakab, G., Karlen, D., Held, M., Mauch-Mani, B., and Turlings, T.C.J. (2007). Priming by airborne signals boosts direct and indirect resistance in maize. Plant J. 49: 16-26.

Towers, G.H.N. 1984. Interactions of light with phytochemicals in some natural and novel systems. Can. J. Bot. 62: 2900-2911. 
Trewavas, A.J., and Malhó, R. (1998) $\mathrm{Ca}^{2+}$ signalling in plant cells: the big network! Curr. Opin. Plant Biol. 1: 428-433.

Trezzini, G.F., Horrichs, A., and Sommssich, I.E. (1993). Isolation of putative defenserelated genes from Arabidopsis thaliana and expression in fungal elicitor-treated cells. Plant Mol. Biol. 21: 385-389.

Turlings, T.C.J., Tumlinson, J.H., and Lewis, W.J. (1990). Explotation of herbivoreinduced plant odors by host-seeking parasitic wasps. Science 250: 1251-1253.

Turner, J.G., Ellis, C., Devoto, A. (2002). The jasmonate signal pathway. The Plant Cell Suplement: S153-S164.

Yalpani, N., León, J., Lawton, M., and Raskin, I. (1993). Pathway of salicylic acid biosynthesis in healthy and virus-inoculated tobacco. Plant Physiol. 103: 315-321.

Yoshihara, T., Takamatsu, S., and Sakamura, S. (1978). Three new phenolic amides from de roots of eggplant (Solanum melongena L.). Agric. Biol. Chem. 42 (3): 623627.

van Kan, J.A.L., Cozijnsen, T., Danhash, N., and de Wit, P.J.G.M. (1995). Induction of tomato stress protein mRNAs by ethephon, 2,6-dichloroisonicotinic acid and salicylate. Plant Mol. Biol. 27: 1025-1213.

van Loon, L.C. (1977). Induction by 2-chloroethylphosphonic acid of viral-like lesions, associated proteins, and systemic resistance in tobacco. Virology 80:417-420.

van Loon, L.C., and Pieterse, C.M.J. (2002). Biocontrol agents in signaling resistance. In Biological Control of Crop Diseases, ed. SS Gnanamanickam, pp. 355-386. New York: Marcel Dekker.

van Loon, L.C., Geraats, B.P., and Linthorst, H.J. (2006a). Ethylene as a modulator of disease resistance in plants. Trends Plant Sci. 11: 184-191.

van Loon, L.C., Rep, M., Pieterse, C.M.J. (2006b). Significance of defense-related proteins in infected plants. Annu. Rev. Phytopathol. 44: 135-162.

van Loon, L.C., and van Kammen, A. (1970). Polyacrylamide disc electrophoresis of the soluble leaf proteins from Nicotinana tabacum var. Samsun and Samsun NN II. Changes in protein constitution after infection with tobacco mosaic virus. Virology 40: 199-211. 
Verbene, M.C., Budi Muljono, A.B., Verpoorte, R. (1999). Salicylic acid biosíntesis. In Biochemistry and Molecular Biology of Plant Hormones, vol. 33. Edited by Libbenga K, Hall M, Hooykaas PJJ. London: Elsevier. pp: 295-312.

Verbene, M.C., Verpoorte, R., Bol, J.F., Mercado-Blanco, J., and Linthorst, H.J. (2000). Overproduction of salicylic acid in plants by bacterial transgenes enhances pathogen resistance. Nat. Biotechnol. 18: 779-783.

Verhagen, B.W., Glazebrook, J., Zhu, T., Chang, H.S., van Loon, L.C. and Pieterse, C.M. (2004). The transcriptome of rhizobacteria-induced systemic resistance in Arabidopsis. Mol. Plant Microbe Interact. 17: 895-908.

Vick, B.A. and Zimmerman, D.C. (1983). The biosynthesis of jasmonic acid: a physiological role for plant lipoxygenase. Biochem. Biophys. Res. Commun. 111: 470-477.

Villegas, M., and Brodelius, P.E. (1990). Elicitor-induced hydroxycinnamoylCoA:tyramine hydroxycinnamoyltransferase in plant cell suspension cultures Physilogy Plantarum 78: 414-420.

Vleeshouwers, V.G.A.A., van Dooijeweert, W., Govers, F., Kamoun, S., and Colon, L.T. (2000). The hypersensitive response is associated with host and nonhost resistance with Phytophthora infestans. Planta 210: 853-864.

von Roepenack-Lahaye, E., Newman, M.A., Schornack, S., Hammond-Kosack, K.E., Lahaye, T., Jones, J.D.G., Daniels, M.J., and Dow, J.M. (2003). pcoumaroylnoradrenaline, a novel plant metabolite implicated in tomato defense against pathogens. J. Biol. Chem. 278: 43373-43383.

Walker, N. and Evans W.C. (1952). Pathways in the metabolism of the monohydroxybenzoic acids by soil bacteria. Biochem. J. 52: 23.

Walling, L.L. (2000). The myriad plant responses to herbivores. J. Plant Growth Regul. 19: 195-216.

Wang, K.L.C., Li, H., and Ecker, J.R. (2002). Ethylene biosynthesis and signaling networks. Plant Cell S131-151

Wasternack, C. (2006). Oxilipins: biosynthesis, signal transduction and action. In: Hedden P, Thomas S., eds. Plant hormone signaling. Annual Reviews. Oxford: Backwell Publishing Ltd., 185-228. 
Weber, H., Vick, B.A. and Farmer, E.E. (1997). Dinor-oxo-phytodienoic acid: a new hexadecanoid signal in the jasmonate family. Proc. Natl. Acad. Sci. U.S.A. 94: 10473-10478.

White, P.J., and Broadley, M. (2003). Calcium in plants. Ann. Bot. 92: 487-511.

Willdermuth, M.C., Dewdney, J., Wu, G., Ausubel, F.M. (2001). Isochorismate synthase is required to synthesize salicylic acid for plant defense. Nature 414: 562565.

Xie, D.X., Feys, B.F., James, S., Nieto-Rostro, M. and Turner, J.G. (1998). COI1: an Arabidopsis gene required for jasmonate-regulated defense and fertility. Science 280: 1091-1094.

Xu, L., Liu, F., Lechner, E., Genschik, P., Crosby, W.L., Ma, H., Peng, W., Huang, D. and Xie, D. (2002). The SCF(COI1) ubiquitin-ligase complexes are required for jasmonate response in Arabidopsis. Plant Cell 14: 1919-1935.

Yamamoto, H., Katano, N., Ooi, A., and Inoue, K. (2000). Secologanin synthase which catalyze the oxidative cleavage of loganin into secologanin is a cytochrome P450. Phytochemistry 53: 7-12.

Yang, T., and Poovaiah, B.W. (2002). A calmodulin-binding/CGCG box DNA-binding protein family involved in multiple signaling pathways in plants. J. Biol. Chem. 277: 45049-45058.

Zhang, H.L., Nagatsu, A., and Sakakibara, J. (1996). Novel antioxidants from safflower (Carthamus tinctorius L.) oil cake. Chem. Pharm. Bull. 44(4): 874-876.

Zhao, J., Hu, Q., Guo, Y.Q., and Zhu W.H. (2001). Elicitor-induced indole alkaloid biosynthesis in Catharanthus roseus cell cultures is related to $\mathrm{Ca}^{2+}$-influxand the oxidative burst. Plant Sci. 161: 423-431.

Zhao, J., Davis, L.C., and Verpoorte, R. (2005). Elicitor signal transduction leading to production of plant secondary metabolites. Biotecnol. Adv. 23: 283-333.

Zhou, J.M., Trifa, Y., Silva, H., Pontier, D., Lam, E., Shah, J. and Klessig, D.F. (2000). NPR1 differentially interacts with members of the TGA/OBF family of transcription factors that bind an element of the PR-1 gene required for induction by salicylic acid. Mol. Plant Microbe. Interact. 13: 191-202. 
Zipfel, C.; Robatzek, S.; Navarro, L.; Oakeley, E.J.; Jones, J.D.G.; Felix, G.; and Boller, T. (2004). Bacterial disease resistance in Arabidopsis throught flagellin perception. Nature 428: 764-767.

Zipfel, C., and Felix, G. (2005) Plants and animals: a different taste for microbes? Curr. Opin. Plant Biol. 8: 353-360. 
Anexos 


\title{
Induction of $p$-Coumaroyldopamine and Feruloyldopamine, Two Novel Metabolites, in Tomato by the Bacterial Pathogen Pseudomonas syringae
}

\author{
Laura Zacarés, ${ }^{1}$ María Pilar López-Gresa, ${ }^{1}$ Joaquín Fayos, ${ }^{1}$ Jaime Primo, ${ }^{2}$ José María Bellés, ${ }^{1}$ and \\ Vicente Conejero'
}

${ }^{1}$ Instituto de Biología Molecular y Celular de Plantas, and ${ }^{2}$ Centro de Ecología Química Agrícola, Universidad Politécnica de Valencia-Consejo Superior de Investigaciones Científicas, Camino de Vera s/n, 46022 Valencia, Spain

Submitted 4 May 2007. Accepted 5 July 2007.

\begin{abstract}
Inoculation of tomato plants (Solanum lycopersicum cv. Rutgers) with Pseudomonas syringae pv. tomato led to the production of a hypersensitive-like response in this pathovar of tomato. Accumulation of hydroxycinnamic acid amides (HCAA) of tyramine ( $p$-coumaroyltyramine and feruloyltyramine) and dopamine ( $p$-coumaroyldopamine and feruloyldopamine) was detected after bacterial infection. Two of them, $p$-coumaroyldopamine and feruloyldopamine, are described for the first time. The accumulation of HCAA was preceded by an increment of hydroxycinnamoylCoA:tyramine $N$-hydroxycinnamoyl transferase $(T H T)$ gene expression. HCAA also accumulated in transgenic NahG tomato plants overexpressing a bacterial salicylic hydroxylase. However, treatment of plants with the ethylene biosynthesis inhibitor, aminoethoxyvinilglycine, led to a reduction in the accumulation of THT transcripts and HCAA. Together, the results suggest that pathogeninduced induction of ethylene is essential for HCAA synthesis, whereas salicylic acid is not required for this response. In addition, notable antibacterial and antioxidant activities were found for the new HCAA, thus indicating that they could play a role in the defense of tomato plants against bacterial infection.
\end{abstract}

Higher plants are continuously exposed to a large range of biotic (viroids, viruses, bacteria, or fungi) and abiotic environmental challenges. They cannot escape from these potentially stressing agents and have developed a staggering and sophisticated battery of defense mechanisms; consequently, most plants are resistant to many pathogens of plants (Dangl and Jones 2001; Dixon et al. 1994). These mechanisms of defense are induced upon infection by pathogens leading to the socalled acquired resistance; however, a preexisting defense in the form of physical and chemical barriers also exists. When a pathogen encounters a plant, two kinds of interactions can be produced between them. In the first case, a gene-for-gene-type interaction is accompanied by cell death, producing a necrotizing reaction or hypersensitive response of the plant. The infection then is restricted to small areas immediately surrounding the initially infected cells and, in turn, signals the activation of defensive reactions in uninfected parts of the plant. These distal sites then become more resistant to subsequent infections. This response is the so-called systemic acquired resistance

Corresponding author: José María Bellés; Telephone: +34 963877880; Fax: +34 963877879; E-mail: jmbelles@btc.upv.es
(Sticher et al. 1997). Sometimes, the defensive response also can be elicited in compatible, non-necrotizing interactions by different pathogens in the absence of gene-for-gene resistance (Conejero et al. 1990; Dixon et al. 1994). Some common responses in both incompatible and compatible interactions include the induction of phenolic salicylic acid (SA; 2-hydroxybenzoic acid) (Dempsey et al. 1999; Métraux et al. 1990), the synthesis of pathogenesis-related proteins (Van Kan et al. 1992; Van Loon et al. 2006b), and natural antimicrobial products (phytoalexins) (Dixon 2001; Hammerschmidt 1999). The role in plant disease resistance of some of these metabolites has been well established in mutant and transgenic plants with altered expression of phenylpropanoid genes or modified levels of phenylpropanoid metabolites (Dixon et al. 2002; Niggeweg et al. 2004; Thomma et al. 1999; Verberne et al. 2000). Cinnamic acid (phenylpropanoid acid) is the product of deamination of phenylanine catalyzed by phenylalanine ammonia-lyase (PAL; L-phenylalanine ammonia-lyase, EC 4.3.1.5), the first regulatory enzyme of the phenylpropanoid pathway. In higher plants, hydroxycinnamic acids such as $p$-coumaric (4-hydroxycinnamic acid) and ferulic (4-hydroxy-3-methoxycinnamic) acids can occur conjugated to the $\beta$-phenylethylamine-alkaloids tyramine (2-[4-hydroxyphenyl] ethylamine) and octopamine [2-hydroxy-2-[4-hydroxyphenyl] ethylamine), forming the corresponding N-hydroxycinnamic acid amides (HCAA) (Facchini et al. 2002; Strack 1997). These compounds are thought to play a defensive role in plants (Hahlbrock and Scheel 1989) and their synthesis is induced upon pathogen infection and in response to various stresses, including wounding or elicitor treatments in different plants tissues (Keller et al. 1996; Negrel and Martin 1984; Newman et al. 2001; Pearce et al. 1998; Schmidt et al. 1998). The pivotal regulatory enzyme responsible for the synthesis of HCAA is the enzyme hydroxycinnamoylCoA:tyramine $N$-hydroxycinnamoyl transferase (THT; EC 2.3.1.110) (Facchini et al. 2002; Negrel and Javelle 1997; Negrel and Martin 1984). Recently, Von Roepenack-Lahaye and associates (2003) have found that the tomato cv. Rio Grande, challenged with the bacterial pathogen Pseudomonas syringae pv. tomato, synthesized $p$-coumaroyloctopamine and the novel plant compound, $p$-coumaroylnoradrenaline, and that the elevated levels of these metabolites were concomitant with an increased expression of a gene encoding the THT isoenzyme.

Tomato plants infected with citrus exocortis viroid, which produces a systemic infection (compatible interaction), strongly accumulated gentisic acid (2,5-dihydroxybenzoic acid, a SA-derivative phenolic) (Bellés et al. 1999; Fayos et al. 2006). It has been demonstrated that gentisic acid acts as a signal, in addition 
to SA, to elicit the upregulation of defense proteins in tomato and cucumber plants (Bellés et al. 1999, 2006). Interestingly, this secondary metabolite did not accumulate when tomato plants were infiltrated with the necrotizing pathogen $P$. syringae pv. tomato, which elicits a hypersensitive-like reaction in tomato leaves (incompatible interaction) (Bellés et al. 1999). In an attempt to identify additional compounds from the phenylpropanoid pathway that might have some role in tomato plant defense, we have studied the synthesis of amides upon challenging tomato leaves with $P$. syringae pv. tomato. We show here the identification of two metabolites for plants: $N$-p-coumaroyldopamine (CD), and $N$-feruloyldopamine (FD), which, to our knowledge are novel compounds. We also observed induction of the wellknown $N$-p-coumaroyltyramine (CT) and $N$-feruloyltyramine (FT), and the expression of the THT gene in P. syringae-infected tomato leaves. The antimicrobial and antioxidant activities of these compounds also were studied. All of them presented a positive antioxidant activity, and the new HCAA of dopamine had a notable bactericidal action. To gain information on the possible signals implicated in the activation of HCAA synthesis after bacterial challenging, we also have explored the implication of ethylene and SA on HCAA accumulation. Interestingly, inhibition experiments of $P$. syringae-induced ethylene with aminoethoxyvinylglycine (AVG) strongly suggest that ethylene is essential to elicit HCAA synthesis. However, exogenous application SA had no effect on HCAA levels in tomato leaves, and NahG tomato plants accumulated HCAA upon bacterial challenge, thus further supporting the notion that SA does not affect the pathogen-induced induction of HCAA synthesis.

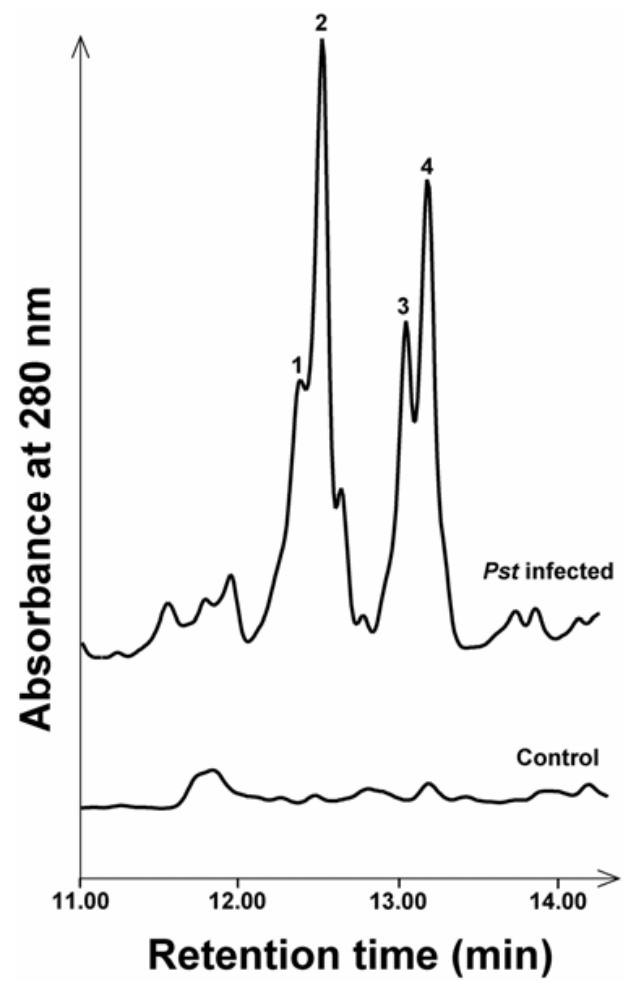

Fig. 1. Representative absorbance chromatograms (recorded at $280 \mathrm{~nm}$ ) obtained after reversed-phase high-performance liquid chromatography (HPLC) separation from soluble methanol leaf extracts of control and infected Rutgers tomato leaves. Plants were mock-inoculated or challenged with Pseudomonas syringae pv. tomato at $10^{7} \mathrm{CFU} / \mathrm{ml}$ (Pst-infected). Samples were collected at $24 \mathrm{~h}$ postinoculation. Absorbance was monitored by a photodiode array detector with a range of maxplot between 240 and $400 \mathrm{~nm}$ and a spectral resolution of $1.2 \mathrm{~nm}$. Peaks 1, 2, 3, and 4 represent the unknown phenolic compounds with retention times of $12.5,12.7,13.2$, and $13.6 \mathrm{~min}$, respectively.

\section{RESULTS AND DISCUSSION}

\section{Characterization of HCAA}

in Rutgers tomato challenged with $P$. syringae.

Rutgers tomato leaves inoculated with the bacterial pathogen P. syringae pv. tomato developed a hypersensitive-like response, manifested as a bacterial concentration-dependent necrotic reaction. In this article, we applied a bacterial concentration of $10^{7}$ $\mathrm{CFU} / \mathrm{ml}$. The method employed to inoculate the bacteria first produced water soaking in the leaves, which disappeared within approximately $1 \mathrm{~h}$. The observation of the hypersensitive reaction began with the glossy appearance of the inoculated leaf surface area (approximately $6 \mathrm{~mm}$ in diameter) and was evident as early as $12 \mathrm{~h}$ after bacterial infiltration. The pathogen response culminated at approximately $72 \mathrm{~h}$ postinoculation with the appearance of nonspreading necrotic brown spots and cellular collapse over the whole inoculated region. Also, at approximately $24 \mathrm{~h}$ after leaf infiltration by the bacteria, a marked epinasty of the inoculated leaves was already evident. Previously, using fluorescence detection of methanolic extracts, we had found that Rutgers tomato leaves infiltrated with $P$. syringae accumulated SA (Bellés et al. 1999), a phenolic associated with the hypersensitive response of plants to pathogens (Dempsey et al. 1999; Métraux and Raskin 1993). Therefore, to extend the search for other metabolites induced in tomato by $P$. syringae, we decided to carry out a more general analysis of UV-absorbing methanolsoluble phenolic compounds in extracts from $P$. syringae-infected tomato leaves. High-performance liquid chromatography (HPLC) chromatograms of methanol-soluble extracts from $P$. syringae-infected Rutgers tomato leaves $24 \mathrm{~h}$ after the challenge are shown in Figure 1. The corresponding control mock-inoculated leaves are shown for comparison. To survey metabolites of the phenylpropanoid pathway, the $280-\mathrm{nm}$ wavelength was selected upon studying the absorbance spectra recorded with the diode array detector by scanning from 240 to $400 \mathrm{~nm}$. As observed, a set of four major peaks (12.5-min, 12.7-min, 13.2-min, and 13.6-min relative retention times) appeared in extracts from $P$. syringae-infected tomato leaves. These peaks did not appear in HPLC chromatograms corresponding to extracts from uninoculated control leaves. In some experiments, such as the one shown in Figure 1, an additional peak with a retention time slightly longer than peak 2 appeared. However, this peak was not observed consistently and we were not able to identify its chemical nature. It is likely to correspond to an artifact due to irregularities in the separation process.

To precisely identify these unknown compounds corresponding to peaks 1 to 4, an HPLC-mass spectrometry (MS) analysis combined with electrospray ionization (ESI) of the soluble-methanol phenolic fraction from infected tomato leaves was performed. Mass spectra fragments of peaks 1 to 4 from methanolic tomato extracts obtained by ESI in the positive ion mode are shown in Table 1. Under mild ionization conditions (cone voltage of $20 \mathrm{~V}$ ), the compounds gave a substantial fragmentation. The mass spectra from total ion current chromatograms showed protonated $(\mathrm{M}+\mathrm{H})^{+}$fragment ions of a mass-to-charge ratio $(\mathrm{m} / \mathrm{z})$ equal to $299,329,283$, and 313 . The product ion scan spectrum of peaks 1 to 4 gave common ions at $m / z, 147$ and 177, which are daughter ions, characteristic of the $p$-coumaroyl and feruloyl moieties, respectively. Peaks 3 and 4 presented UV spectra identical to that of authentic CT and FT and cochromatographed with synthesized standards. Mass spectra of peaks 1 and 2 showed, in addition to common ions at $\mathrm{m} / \mathrm{z} 147$ and 177, a 16-Da higher $(\mathrm{M}+\mathrm{H})^{+}$at $\mathrm{m} / z 299$ and 329, revealing a structure with one additional hydroxyl group, compared with tyramine, in the amine moiety. The presence of these additional ions is compatible with the identification of these compounds as conjugated amines, such as 
octopamine (hydroxyl group is joined to carbon 7), or dopamine (hydroxyl function is joined to benzylic ring). We were able to positively identify peaks 1 and 2 as $p$-coumaroyldopamine and feruloyldopamine, respectively, based on the absence of a strong and characteristic $\left(\mathrm{M}+\mathrm{H}-\mathrm{H}_{2} \mathrm{O}\right)^{+}$ion present in the ESI spectra of amine conjugates with the hydroxyl group

Table 1. Electrospray ionization mass spectra comparisons ${ }^{\mathrm{a}}$

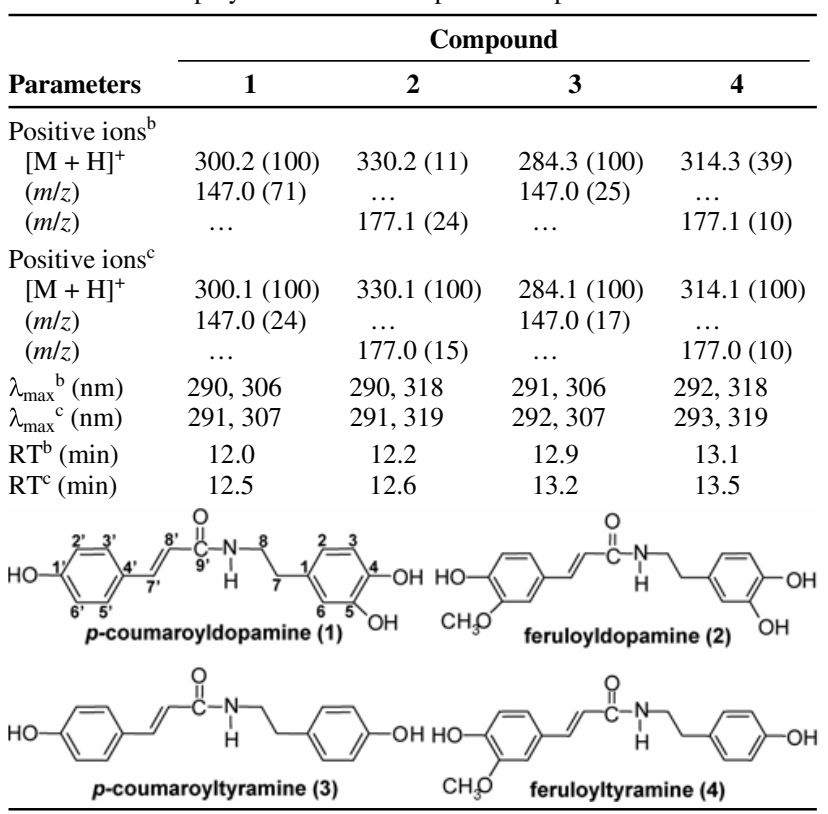

${ }^{a}$ Ion positive detection mode $(\mathrm{m} / \mathrm{z}[\%])$, absorbance maxima $(\mathrm{nm})$, and retention times.

${ }^{\mathrm{b}}$ Results of peaks $1,2,3$, and 4 .

${ }^{\mathrm{c}}$ Results of synthetic hydroxycinnamic acid amides. joined to carbon 7 of the amine moiety (which is the case of octopamine) (Schmidt et al. 1999; Von Roepenack-Lahaye et al. 2003). In addition, these compounds cochromatographed with and have identical UV spectra to that of authentic HCAA that had been chemically synthesized. To our knowledge, this is the first evidence of the presence of HCAA of dopamine in plants.

\section{Accumulation of HCAA}

in tomato infected with $P$. syringae.

Results of the analysis of the time course of induction of p$\mathrm{CD}, \mathrm{FD}, \mathrm{p}-\mathrm{CT}$, and FT in Rutgers tomato leaves upon $P$. syringae challenge is presented in Figure 2A. The relative timing of the maximum accumulation of HCAA, approximately $24 \mathrm{~h}$ postinoculation, preceded the formation of necrotic brown spots, which appear after $72 \mathrm{~h}$ postinoculation. The accumulation profiles for FD and FT were quite similar and different from that of CD and CT, which also were similar. The levels of all HCAA increased in a time-dependent manner, reaching their maximum level at $24 \mathrm{~h}$ after inoculation and decreasing thereafter in the case of FD and FT, whereas the levels of CD and CT remained at this comparatively high level during the subsequent 2 days ( $72 \mathrm{~h}$ after inoculation). The maximum level of these compounds differ between amides, with the highest observed value corresponding to FD (46 nmol/g fresh weight) and the lowest to $\mathrm{CD}(1.7 \mathrm{nmol} / \mathrm{g}$ fresh weight).

In order to determine the localization of the production of HCAA, we compared the levels present in the inoculated area and the immediately surrounding tissue (approximately $1 \mathrm{~mm}$ ) with the accumulation in the remaining noninoculated leaflet. The increase in HCAA primarily was confined to and around the inoculated region (Fig. 2B). This location was similar to that previously reported for HCAA of tyramine in tomato (Pearce et al. 1998) and tobacco (Guillet and De Luca 2005) leaves after wounding.
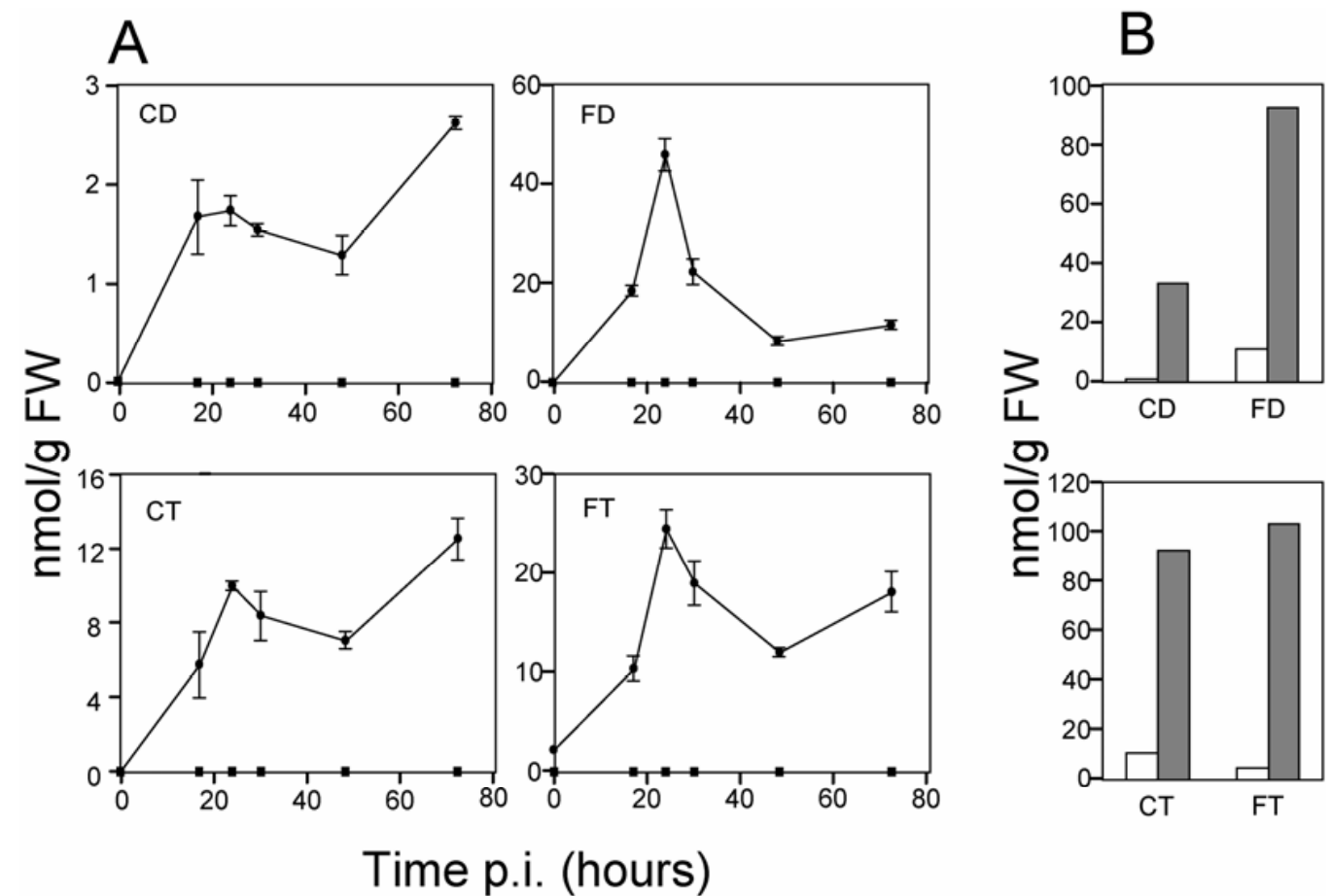

Fig. 2. A, Time courses for the accumulation of $p$-coumaroyldopamine (CD), feruloyldopamine (FD), $p$-coumaroyltyramine (CT), and feruloyltyramine (FT) in Rutgers tomato leaves at the specified times postinoculation (p.i.) with Pseudomonas syringae pv. tomato at $10^{7} \mathrm{CFU} / \mathrm{ml}$. Results are the mean \pm standard error from three replicates. B, Accumulation of CD, FD, CT, and FT at $24 \mathrm{~h}$ postinoculation in the inoculated area and the immediately surrounding tissues (approximately $1 \mathrm{~mm}$ ) (gray bars) compared with the accumulation in the adjacent tissue (white bars). FW, fresh weight. 
The four HCAA described above as being associated with the tomato Rutgers- $P$. syringae interaction were accumulated in a similar way in two additional tomato cultivars (Ailsa Craig and Moneymaker) upon $P$. syringae pv. tomato inoculation (data not shown). The fact that these compounds had not been detected in Rio Grande tomato infected with P. syringae (Von Roepenack-Lahaye et al. 2003) and that we have not found the HCAA described by these authors may be due to differential cultivar behavior. The time course of induction and relative timing of the accumulation of these amine conjugates in Rutgers tomato leaves challenged with $P$. syringae was comparable with that observed for FT and CT in pepper leaves infected with Xanthomonas campestris (Newmann et al. 2001) and for $p$-coumaroylnoradrenaline in Rio Grande tomato infected with $P$. syringae. Increased synthesis of $p$-coumaroyloctopamine and $p$-coumaroylnoradrenaline associated with $P$. syringae infection of tomato plants or treatment with elicitors from the fungus Cladosporium fulvum have been reported (Von RoepenackLahaye et al. 2003). Biosynthesis of FT and CT was induced in tomato leaves in response to wounding (Pearce et al. 1998), and FT accumulated in tobacco leaves after infection with Tobacco mosaic virus (Negrel and Jeandet 1987). CT and FT were associated with the resistance reactions of pepper to $X$. campestris (Newman et al. 2001) and of potato to Phytophthora infestans (Keller et al. 1996).

In plants, the storage form of many phenolic derivatives is conjugated to sugars (Harborne 1980). Hydrolysis of these conjugated forms could constitute a source of free HCAA as an alternative to their biosynthetic pathway. Therefore, we also have investigated the possible presence of glycosyl derivatives of the accumulated amides in tomato upon bacterial infection. After treatment of methanolic extracts from Pseudomonas syringae-inoculated tomato leaves with $\beta$-glucosidase and esterase, no release of any free CT, FT, CD, or FD could be detected. This result indicates that the amides were not accumulated as sugar conjugates. Similar results were obtained by Newman and associates (2001) for CT and FT in pepper leaves elicited by $X$. campestris.

Recently, Niehl and associates (2006), studying the compatible interaction between Solanum tuberosum and Potato virus $X$, have hypothesized that tyramine and dopamine (both highly induced upon infection) can contribute to active plant defense responses by forming hydroxcinnamic acid amides, which increases cell wall stability and fortification. However, the authors were not able to directly identify the HCAA of tyramine and dopamine in infected leaf material. In this work, we have found that these HCAA accumulated in tomato plants after

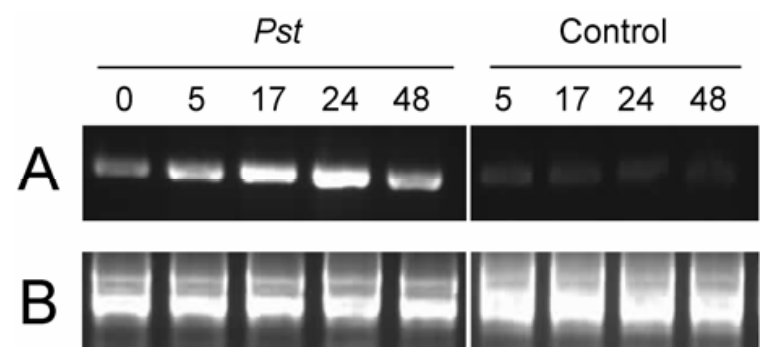

Fig. 3. Expression of tyramine hydroxycinnamoyl transferase (THT) transcripts in Rutgers tomato infected with Pseudomonas syringe pv. tomato (Pst) at $10^{7} \mathrm{CFU} / \mathrm{ml}$. A, THT cDNA. B, Ribosomal RNA loading control. Total RNA $(10 \mu \mathrm{g})$ was prepared from $P$. syringe pv. tomato -infected and control tomato leaves and reverse-transcribed using $T H T$-specific primers. The resulting RT-PCR products were separated on $1 \%$ agarose gels. Total RNA $(2 \mu \mathrm{g})$ from each of the indicated samples is shown as a loading control. The gels were stained with ethidium bromide and visualized under UV light. Samples were collected at the specified times (h). Similar results were observed in two separate experiments. infection with a necrotizing pathogen. The results presented in this report extend to other plant systems and to other classes of HCAA the important role that these metabolites could play in plant resistance to pathogens, as previously suggested by others (Newman et al. 2001; Von Roepenack-Lahaye et al. 2003).

\section{Induction of $T H T$ gene expression precedes}

HCAA accumulation in tomato infected with $P$. syringae.

Total RNA was isolated at different time points after the onset of bacterial infiltration and subjected to reverse-transcription polymerase chain reaction (RT-PCR) analysis to determine the expression levels of mRNA encoding the THT1-3 isoenzyme (Von Roepenack-Lahaye et al. 2003). The kinetic pattern of THT transcript accumulation at the specified times is shown in Figure 3A. THT transcripts of 724-bp size began to accumulate as early as $5 \mathrm{~h}$ after inoculation of the leaves. Maximal transcript levels are detected at $24 \mathrm{~h}$, and decline thereafter. Comparison of the kinetics of the induction patterns of THT transcript levels (Fig. 3A) and HCAA accumulation (Fig. 2A) demonstrated an association between HCAA production and alterations in transcription of THT. As expected, the increment of the THT gene expression occurred earlier than that of HCAA accumulation. These results suggest that activation of the THT gene expression results in an increase of HCAA synthesis in a manner similar to that observed in other plant-pathogen interactions (Newman et al. 2001; Von Roepenack-Lahaye et al. 2003). Mock-inoculated tomato leaves do not show an incremental increase in the level of THT transcripts. The time course of the induction of THT transcripts observed in cv. Rutgers is in agreement with that observed in cv. Rio Grande upon P. syringae infection (Von Roepenack-Lahaye et al. 2003), and is comparable with that observed in potato cell cultures after $P$. infestans elicitor treatment (Schmidt et al. 1999) or pepper infected with X. campestris (Newman et al. 2001).

\section{Ethylene is essential for the induction} of THT gene expression and the accumulation of HCAA.

Initial studies on the interaction between Rutgers tomato and the bacterial pathogen $P$. syringae showed that infection of the leaves with this pathogen caused a rapid and pronounced synthesis of the plant hormone ethylene, a well-known response of plants to different pathogenic infections (Van Loon et al. 2006a). Previously, it had been thought (Boller 1990) that ethylene, generated in response to pathogens, would have a role in the induction of antimicrobial phytoalexins; although, in some plant-pathogen interactions, ethylene does not appear to be important for this response (Boller 1990; Reinhardt et al. 1991). Therefore, to establish the implication of ethylene in the tomato defense reactions studied in this work, we first examined whether application of exogenous ethylene was able to activate THT expression and HCAA accumulation in Rutgers tomato. Accordingly, tomato plants were treated with exogenous ethylene $(50 \mu \mathrm{l} /$ liter $)$, as indicated below. Ethylene treatment led to an increase in the expression levels of THT transcripts compared with control plants by $24 \mathrm{~h}$ (Fig. 4B). This result is consistent with the elevated levels of HCAA in ethylene-treated plants (Fig. 4A). The increments of THT expression in ethylene-treated plants were comparable with that in $P$. syringae-infected tomato leaves at the same time after the inoculation. To our knowledge, this is the first direct demonstration of ethylene-induced THT expression.

To explore the role of $P$. syringae induced-ethylene in eliciting THT expression and HCAA synthesis, the ethylene biosynthesis inhibitor AVG was used instead of tomato mutants (e.g., pTOM 13) affected in ethylene production. We chose this approach based on observations made in our laboratory that the inhibitory effect on ethylene accumulation produced by AVG 
treatments is much higher than that observed in pTOM 13. Accordingly, tomato leaves were sprayed with AVG (Adams and Yang 1979), and ethylene production, THT transcripts, and HCAA accumulation were monitored at the specific times after challenging the leaves. The time course of ethylene production in P. syringae-challenged tomato leaves is similar, although with an anticipated induction, to that found in tomato leaves infected with $X$. campestris (Fig. 5A) (Ciardi et al. 2000). Ethylene synthesis began to increase at $5 \mathrm{~h}$ after bacterial inoculation and peaked at approximately $17 \mathrm{~h}$ after infection, markedly declined thereafter to levels comparable with those observed at $5 \mathrm{~h}$, and remained at this comparatively high level during the next hours. The ethylene production of uninoculated tomato leaves remained at a steady low level over the time period of the experiment. Exogenous application of $1 \mathrm{mM}$ AVG markedly inhibited the burst of ethylene production occurring by $17 \mathrm{~h}$ postinoculation and also over the time period studied (Fig. 5A). In addition, AVG treatment also notably reduced THT expression throughout the 48-h time course (Fig. 5B). Importantly, activation of HCAA synthesis was notably blocked in the presence of AVG at 24 and $48 \mathrm{~h}$ after bacterial inoculation (Fig. 5C). The inhibition was higher for CT and FT, at both at 24 or $48 \mathrm{~h}$, than for CD and FD. However, no blockage of HCAA accumulation was observed at 5 and $17 \mathrm{~h}$ after inoculation of the leaves (data not shown), probably because the effect of AVG on THT gene expression is still too low to reduce HCAA synthesis. These results suggest that ethylene, generated after $P$. syringae infection, is essential for the induction of THT gene expression and HCAA accumulation. These observations are in accordance with the conclusive evidence obtained on the crucial role of ethylene signaling in tomato to respond to pathogen infections (Díaz et al. 2002; Lund et al. 1998) and to elicit pathogenesis-related proteins (Conejero et al. 1990). Moreover, a correlation between infection or wounding and THT production had been previously reported (Ishihara et al. 2000; Negrel et al. 1993, 1995; Pearce et al. 1998). Similarly, it is well known that wounding stimulates the
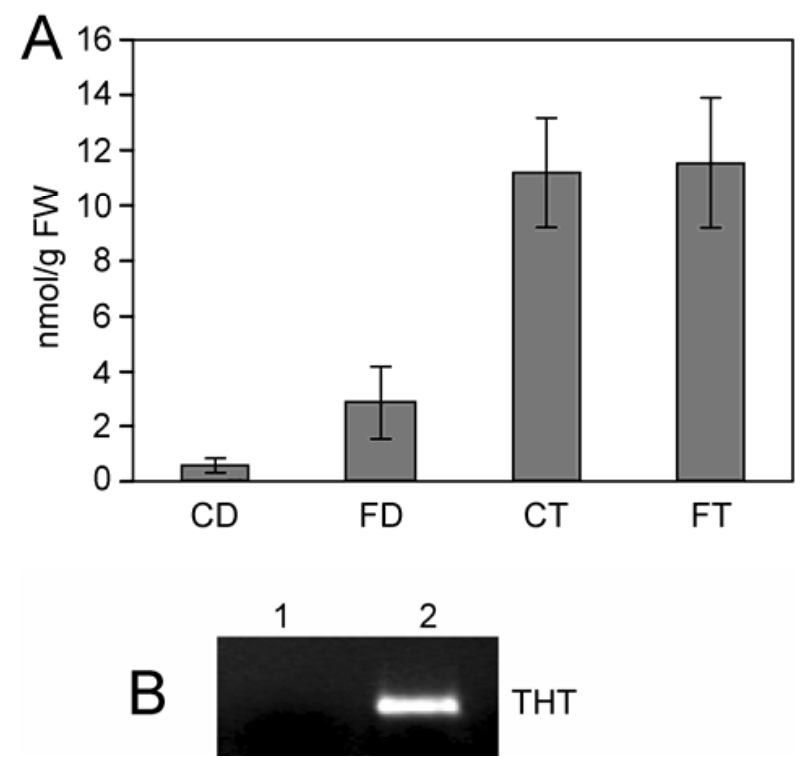

Fig. 4. Effect of exogenous ethylene treatment of Rutgers tomato plants on $\mathbf{A}$, hydroxycinnamic acid amides (HCAA) accumulation and $\mathbf{B}$, tyramine hydroxycinnamoyl transferase $(T H T)$ gene expression. Plants were treated for $24 \mathrm{~h}$ with either ethylene at $50 \mu \mathrm{l} /$ liter or air, and then samples were processed to measure HCAA content and for RNA extraction and reversetranscription polymerase chain reaction analysis. Measures of HCAA are the mean \pm standard error of three replicates; $p$-coumaroyldopamine $=\mathrm{CD}$, feruloyldopamine $=\mathrm{FD}, p$-coumaroyltyramine $=\mathrm{CT}$, feruloyltyramine $=$ FT, and FW = fresh weight.
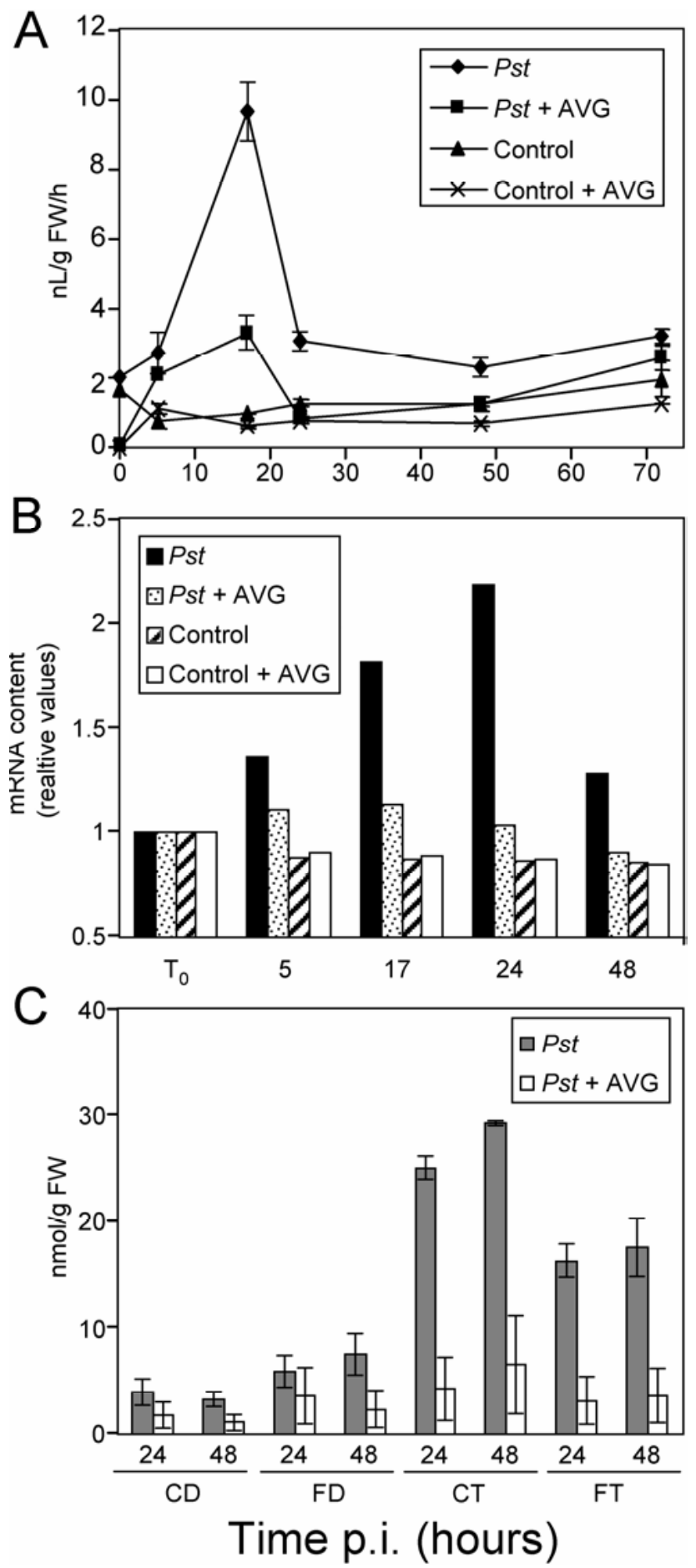

Fig. 5. A, Time course of ethylene production in Rutgers tomato leaves infected with Pseudomonas syringae pv. tomato at $10^{7} \mathrm{CFU} / \mathrm{ml}$ or pretreated with aminoethoxyvinilglycine (AVG) and then inoculated with the bacteria. Time course of ethylene production in the corresponding controls also is included. Samples were collected at the indicated times for ethylene measurements. Results are the mean \pm standard error from three replicates. B, Effect of AVG on tyramine hydroxycinnamoyl transferase (THT) gene expression. Relative THT mRNA amounts obtained by reverse-transcription polymerase chain reaction before infection $\left(\mathrm{T}_{0}\right)$ and at the indicated times postinoculation were determined. Similar results were observed in two separate experiments. $\mathbf{C}$, Effect of AVG on hydroxycinnamic acid amides (HCAA) accumulation in Rutgers tomato plants infected by Ps. syringae at 24 and $48 \mathrm{~h}$ postinoculation. Measures of HCAA are the mean \pm standard error of three replicates; $p$-coumaroyldopamine $=\mathrm{CD}$, feruloyldopamine $=\mathrm{FD}, p$-coumaroyltyramine $=\mathrm{CT}$, feruloyltyramine $=$ $\mathrm{FT}$, and $\mathrm{FW}=$ fresh weight. 
production of ethylene. Here, we show that ethylene is necessary for the induction of the expression of THT. Taken together, these results suggest that ethylene production plays an important role in THT induction in response not only to infection but also to wounding.

SA is not necessary for activation of HCAA synthesis.

SA is a crucial signal to elicit plant defense reactions and its levels strongly increase after pathogen invasion (Dempsey et
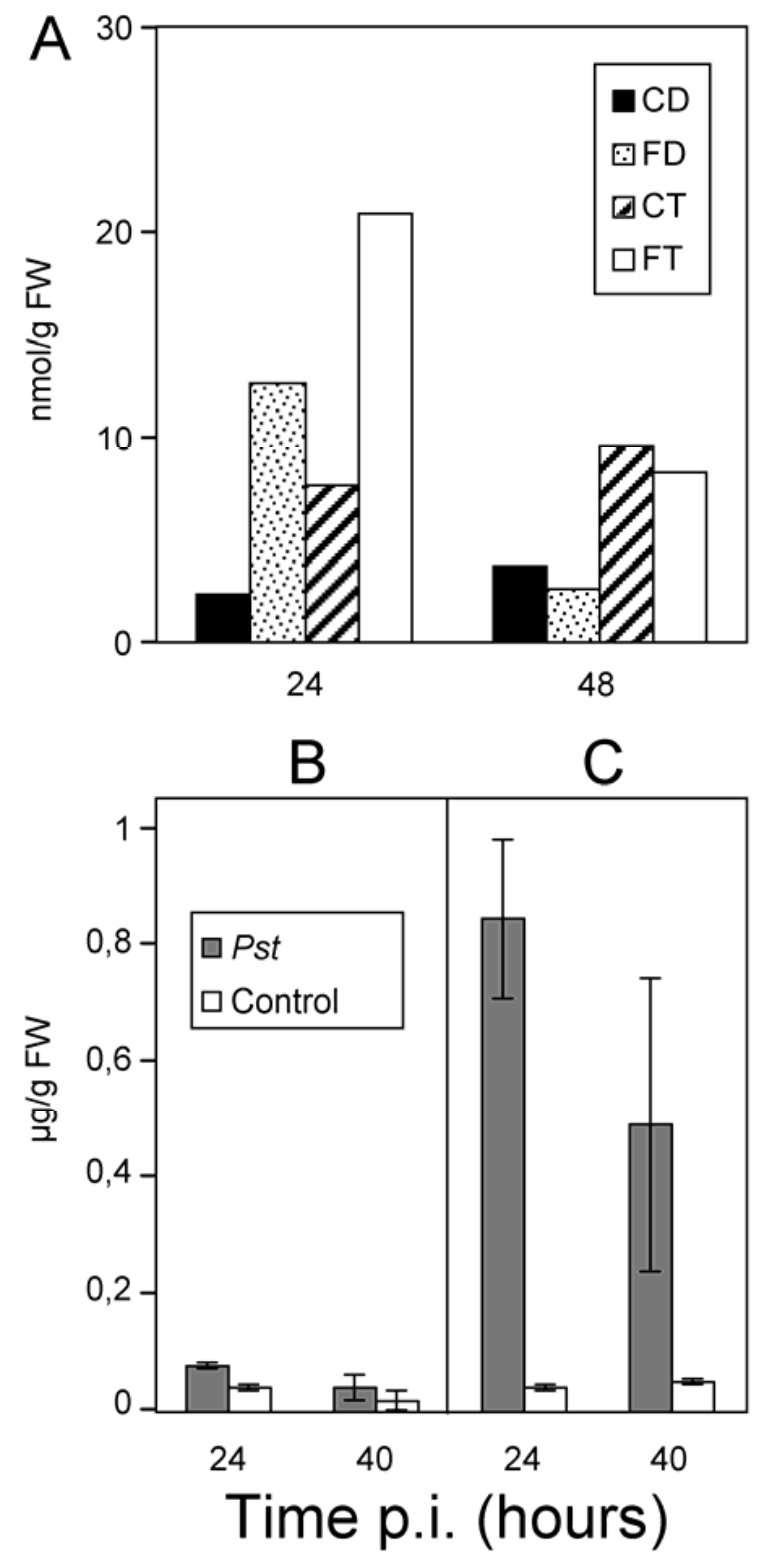

Fig. 6. A, Accumulation of hydroxycinnamic acid amides (HCAA) in NahG transgenic tomato plants infected with Pseudomonas syringae pv. tomato at $10^{7} \mathrm{CFU} / \mathrm{ml}$. Samples were collected at 24 and $48 \mathrm{~h}$ postinoculation (hpi) with the bacteria. Results are the mean of two replicates and similar results were obtained in two separate experiments. B, Levels of total salicylic acid (SA) (the sum of free SA and its conjugated glucoside, SAG) in NahG transgenic tomato plants infected with $P$. syringae pv. tomato and in the corresponding control. Samples were collected at 24 and $40 \mathrm{hpi}$. Results are the mean \pm standard error of three replicates. C, Levels of total SA (the sum of free SA and its conjugated glucoside, SAG) in Moneymaker tomato infected with $P$. syringae pv. tomato and in the corresponding control. Samples were collected at 24 and $40 \mathrm{hpi}$. Results are the mean \pm standard error of three replicates; $p$-coumaroyldopamine $=\mathrm{CD}$, feruloyldopamine $=\mathrm{FD}, p$-coumaroyltyramine $=\mathrm{CT}$, feruloyltyramine $=\mathrm{FT}$, and $\mathrm{FW}=$ fresh weight. al. 1999; Métraux and Raskin 1993). Previously, we had found that Rutgers tomato infected with $P$. syringae produced a rapid and sharp increase of SA after bacterial inoculation (Bellés et al. 1999). To study the possible role of SA in the induction of HCAA in this plant-pathogen interaction, tomato plants were treated with SA. Surprisingly, no induction of HCAA was detected (data not shown) when Rutgers plants were treated with $\mathrm{SA}$ at concentrations known to induce defense responses in tomato (Bellés et al. 1999; Van Kan et al. 1995). NahG tomato plants overexpressing a bacterial salicylic hydroxylase, which converts SA into catechol (Brading et al. 2000), were used to confirm that SA is not implicated in HCAA induction. To this purpose, these plants were infected with $P$. syringae. Noninfected plants were employed as controls. HCAA accumulation at 24 and $48 \mathrm{~h}$ postinoculation is shown in Figure 6A. No detectable levels of these compounds were found in control plants (data not shown). To be sure that SA induced upon bacterial challenge had been completely eliminated in NahG tomato plants, SA was monitored in the P. syringae-infected tomato leaves from these plants. No accumulation of SA was observed in infected NahG plants (Fig. 6B), contrary to what happened in control Moneymaker-infected plants (Fig. 6C). All these results further indicated that the accumulation of these HCAA is independent of SA as an intermediary signal. However, Nawrath and Métraux (1999), using the same bacterial pathovar but different host plant (NahG Arabidopsis) (Delaney et al. 1994), demonstrated that SA was necessary for the accumulation of camalexin, the major phytoalexin in Arabidopsis, in response to this bacterial infection.

\section{Antibacterial and antioxidant activities of HCAA.}

Up to now, the antimicrobial activity of FT and CT has been investigated in a few cases (McLusky et al. 1999; Newman et al. 2001). However, no reports exist on the antibacterial activity of FD or CD. In the present work, we have shown that FD and $\mathrm{CD}$ have a notable antibacterial activity against $P$. syringae compared with the tetracycline chlorhydrate as a control, thus suggesting that these two new HCAA of dopamine can act as direct antimicrobial agents. Surprisingly, no significant antibacterial effect was observed for HCAA of tyramine (Table 2). These results differ from those reported by Newman and associates (2001) working with other bacteria. These authors found a marked antibacterial activity of FT and CT against $X$. campestris pv. campestris. In this respect, other reports also have shown no conclusive evidence for antimicrobial action of FT and CT against fungi (i.e., Grandmaison and associates [1993] reported that FT reduces the development of vesicular-arbus-

Table 2. Antibacterial activity of hydroxycinnamic acid amides (HCAA) ${ }^{\mathrm{a}}$

\begin{tabular}{lcc}
\hline Compound & MIC $(\mu \mathbf{g} / \mu \mathbf{l})$ & $\mathbf{E D}_{\mathbf{5 0}}(\boldsymbol{\mu M})^{\mathbf{b}}$ \\
\hline$p$-coumaroyldopamine & 5 & $56.37 \pm 0.01$ \\
Feruloyldopamine & 5 & $77.96 \pm 0.03$ \\
$p$-coumaroyltyramine & $>40$ & $>200$ \\
Feruloyltyramine & $>40$ & $150.15 \pm 0.1$ \\
Tetracycline & $1.2 \times 10^{-3}$ & $\ldots$ \\
$p$-coumaric acid & $\ldots$ & $>200$ \\
Ferulic acid & $\ldots$ & $47.18 \pm 0.01$ \\
Dopamine & $\ldots$ & $11.30 \pm 0.01$ \\
Tyramine & $\ldots$ & $>200$ \\
BHT & $\ldots$ & $61.13 \pm 0.02$ \\
\hline
\end{tabular}

${ }^{a}$ Measured as minimal inhibition concentration (MIC). Values are the mean of three individual experiments.

b 2,2-Diphenyl-1-picrylhydrazyl (DPPH) scavenging activity of HCAA, hydroxycinnamic acids, and $\beta$-phenylethyl-alkaloids. Values represent the concentration of product necessary to reduce to $50 \%$ the absorbance of DPPH $\left(\mathrm{ED}_{50}\right)$ and are the mean \pm standard error of three individual experiments. 
cular mycorrhizal fungi; however, McLusky and associates [1999] found that FT and CT had no antifungal effect on Botrytis allii and $B$. cinerea). Other class of HCAA have been shown to posses an important antimicrobial activity against bacteria or fungi as $p$-coumaroylnoradrenaline (Von RoepenackLahaye et al. 2003) or the $\beta$-phenylethylamine serotonin, 3-(2aminoethyl)-5-hydroxyindol (Tanaka et al. 2003), respectively.

As far as we know, the antioxidant activity of HCAA of tyramine and dopamine has not been investigated. In this work, we present a potent CD and FD 2,2-diphenyl-1-picrylhydrazyl (DPPH) scavenging activity comparable with the positive control butylated hydroxytoluene (BHT). These results demonstrate the notable antioxidant activity of these compounds (Table 2), similar to that observed for a series of phenolic acid derivatives (Cos et al. 2002) and dimers of serotonin (Zhang et al. 1996). However, the antioxidant activity of tyramine conjugates was significantly lower than that observed for the dopamine conjugates (Table 2). Moreover, it is interesting to note that the DPPH scavenging activity of dopamine was much stronger than that of tyramine. In agreement to what has been suggested by Cos and associates (2002), our results confirm that the presence of dopamine in an HCAA is crucial for its DPPH scavenging activity. Evidence for the beneficial antimicrobial and antioxidant properties of naturally occurring polyphenolic compounds is accumulating (Dixon 1999). In plants, the antioxidant metabolites could scavenge or prevent the accumulation of reactive oxygen species produced at high rates upon exposure to a pathogen infection (Matamoros et al. 2003). Engineered tomato plants accumulating high levels of chlorogenic acid (a widespread phenolic) show improved antioxidant capacity and resistance to infection by a bacterial pathogen (Niggeweg et al. 2004).

Recently, Niehl and associates (2006) have found that systemic Potato virus $X$ infection induced THT gene expression and accumulation of dopamine in potato leaves. These authors suggested that dopamine could be conjugated into HCAA upon pathogen infection and then participate in the active defense of potato plants. However, they were not able to directly identify the CD and FD conjugated forms in infected tissues. To our knowledge, the presence of HCAA of dopamine in plants has not been reported thus far. This is the first report describing the possible implication of these HCAA in a plantpathogen interaction, and it further supports the role of HCAA as integral components of plant defense responses to pathogen challenge, as has been previously hypothesized (Facchini et al. 2002). Work is in progress to engineer tomato plants with elevated levels of the THT enzyme in order to determine whether these dopamine conjugates accumulate. If successful, this would represent a useful tool to study the role of HCAA of dopamine as both direct barriers against pathogen attack and as antioxidants and bactericidal agents in tomato-pathogen interactions in vivo. Similar strategies have been applied in tobacco and rice and, in both cases, accumulation of similar metabolites was observed (Hagel and Facchini 2005; Jang et al. 2004). However, the role of accumulation of these related compounds in pathogen defense was not investigated.

\section{MATERIALS AND METHODS}

\section{Plant material and inoculation procedure.}

Seeds from tomato (S. lycopersicum cv. Rutgers) (Western Hybrid Seeds Inc., Hamilton City, CA, U.S.A.) or from transgenic tomato plants overexpressing a bacterial hydroxylase (naHG gene) (Brading et al. 2000) provided by J. D. G. Jones (John Innes Centre, Norwich, U.K.) were used in the experiments. The plants (one per pot) were grown in a controlled growth room at 27 and $23^{\circ} \mathrm{C}(16$-h day and 8-h night, respec- tively), relative humidity from 50 to $70 \%$, in 15 -cm-diameter pots containing a 1:1 mixture of peat (Biolan, Kauttua, Finland) and vermiculite. The pots were subirrigated with a nutrient solution as described (Naranjo et al. 2003). Infection of 5-week-old tomato plants at the five- to six-leaf stage with $P$. syringae pv. tomato was performed with a bacterial suspension obtained as follows: bacteria were grown overnight at $28^{\circ} \mathrm{C}$ in 20 -ml petri dishes with $\mathrm{C} 3$ agar medium (Oxoid, Basington, U.K.) supplemented with $0.45 \mathrm{~g}$ of $\mathrm{KH}_{2} \mathrm{PO}_{4}$ per liter and $2.39 \mathrm{~g}$ of $\mathrm{Na}_{2} \mathrm{HPO}_{4} \cdot 12 \mathrm{H}_{2} \mathrm{O}(\mathrm{pH}$ 6.8) per liter. Bacterial colonies then were resuspended in $10 \mathrm{mM} \mathrm{MgSO}$ to a final concentration of optical density at $600 \mathrm{~nm}=0.1$. Dilution plating was used to determine the final inoculum concentration, which averaged $10^{7} \mathrm{CFU} / \mathrm{ml}$. The inoculation procedure was that described in detail by Collinge and associates (1987). Briefly, aliquots of $100 \mu \mathrm{l}$ of this bacterial suspension were injected into the abaxial side of each leaflet (three to four panels per leaflet averaging $30 \mathrm{~mm}^{2}$ ) of the third or fourth leaf from the base of the plant with a 1-ml sterilized plastic syringe without needle. Equivalent control leaflets were mock inoculated with $10 \mathrm{mM} \mathrm{MgSO}_{4}$.

\section{Extraction and HPLC analysis of HCAA and SA.}

Extraction of methanol-soluble HCAA and SA from tomato leaflets was done according to protocols previously published (Bellés et al. 2006; Naranjo et al. 2003). Briefly, leaflets (0.3 to $0.5 \mathrm{~g}$ fresh weight) of tissue were ground with a pestle in a mortar using liquid nitrogen, then homogenized in $1.5 \mathrm{ml}$ of $90 \%$ methanol. The extracts were vortexed vigorously, sonicated for $15 \mathrm{~min}$, and then centrifuged at $14,000 \times g$ for $15 \mathrm{~min}$ using 2$\mathrm{ml}$ Eppendorf tubes to remove cellular debris. The supernatant $(1.5 \mathrm{ml})$ was divided in two halves and dried under nitrogen at $40^{\circ} \mathrm{C}$ using glass tubes of $5 \mathrm{ml}$. One half was dissolved in $1 \mathrm{ml}$ of $5 \%$ perchloric acid and kept for $1 \mathrm{~h}$ at $4^{\circ} \mathrm{C}$ and centrifuged at $14,000 \times g$ for $15 \mathrm{~min}$ to remove polymers. The supernatant was extracted with $2.5 \mathrm{ml}$ of 1:1 cyclopentane/ethyl acetate using glass tubes of $5 \mathrm{ml}$. The organic upper phase was collected and dried at $40^{\circ} \mathrm{C}$ under a flow of nitrogen. The residue was resuspended in $200 \mu \mathrm{l}$ of methanol and filtered through $0.45-\mu \mathrm{m}$ Spartan 13/0.45RC filters (Schleicher \& Schuell, Keene, NH, U.S.A.) nylon filters (Waters, Millford, MA, U.S.A.). For hydrolysis experiments, the other half was dissolved in $1 \mathrm{ml}$ of 0.1 $\mathrm{M}$ sodium acetate $(\mathrm{pH} 4.5)$ containing 10 units of almond $\beta$-glucosidase (EC 3.2.1.21) (14.3 U/mg, Fluka, Buchs, Switzerland) and incubated at $37^{\circ} \mathrm{C}$ for $3 \mathrm{~h}$. The reaction was stopped by adding perchloric acid $(70 \%)$ until a final concentration of $5 \%$ and then maintained at $4^{\circ} \mathrm{C}$ for $1 \mathrm{~h}$. After centrifugation at $14,000 \times$ $g$ for $15 \mathrm{~min}$, the remaining supernatant was extracted as above and the dried residue resuspended in $200 \mu \mathrm{l}$ of methanol and filtered through $0.45-\mu \mathrm{m}$ nylon filters. Aliquots $(40 \mu \mathrm{l})$ were injected with a Waters 717 autosampler into a reverse-phase Symmetry $5-\mu \mathrm{m} \mathrm{C18} \mathrm{(4.6} \mathrm{by} 150 \mathrm{~mm}$; Waters) column equilibrated in $1 \%$ acetic acid. Eluents were $1 \%$ acetic acid (eluent $\mathrm{A}$ ) and methanol (eluent B). A lineal gradient starting with $100 \%$ eluent $A$ and $0 \%$ eluent B and ending with $0 \%$ eluent $A$ and $100 \%$ eluent B was applied over $20 \mathrm{~min}$ at a flow rate of $1 \mathrm{ml} / \mathrm{min}$. After washing the column with $100 \%$ methanol for $10 \mathrm{~min}$, the initial conditions again were applied and the column was allowed to equilibrate with $1 \%$ acetic acid for $10 \mathrm{~min}$, with a total run time of $40 \mathrm{~min}$. The temperature of the oven was $30^{\circ} \mathrm{C}$. HCAA were detected photometrically $(\lambda 280 \mathrm{~nm})$ with a Waters 460 tunable absorbance detector. Total SA (the sum of free SA and its conjugated glucoside, SAG) was detected with a 470 Waters fluorescence detector $(\lambda$ excitation $=313 \mathrm{~nm} ; \lambda$ emission $=405 \mathrm{~nm})$. HCAA and SA were quantified with the Waters Millennium ${ }^{32}$ software using synthesized HCAA and authentic SA, respectively, as standards. Data were corrected for losses in the extrac- 
tion procedure, and recovery of metabolites ranged between 50 and $80 \%$.

\section{Identification of HCAA.}

To identify the structure of the major peaks from methanolsoluble extracts of $P$. syringae-infected tomato leaves, samples, extracted as indicated above, were analyzed by ESI-MS using a 1515 Waters HPLC binary pump, a 996 Waters photodiode detector (range of maxplot between 240 and $400 \mathrm{~nm}$, spectral resolution of $1.2 \mathrm{~nm}$ ), and a ZMD Waters single quadrupole mass spectrometer equipped with an electrospray ionization ion source. The source parameters of the mass spectrometer for ESI in positive mode were the following: capillary voltage $2,500 \mathrm{~V}$, cone voltage $20 \mathrm{~V}$, extractor $5 \mathrm{~V}$, RF Lens $0.5 \mathrm{~V}$, source block temperature $100^{\circ} \mathrm{C}$, and desolvation gas temperature $300^{\circ} \mathrm{C}$. The desolvation and cone gas used was nitrogen at a flow of 400 and 60 liters/min, respectively. Other mass spectrometer conditions were: low mass resolution 13.5, high mass resolution 13.5, ion energy 0.5 , and multiplier 650 . ESI data acquisition was in the conditions of a full scan range from mass-to-charge ratio $(\mathrm{m} / \mathrm{z}) 100$ to 700 at $1 \mathrm{~s} / \mathrm{scan}$. Samples $(20$ $\mu \mathrm{l})$ from methanolic extracts were injected at room temperature into a reverse-phase Symmetry 5 - $\mu \mathrm{m} \mathrm{C18} \mathrm{(4.6} \mathrm{by} 150$ $\mathrm{mm}$; Waters) column. A 20-min linear gradient of $1 \%$ (vol/vol) acetic acid (J. T. Baker) in Milli Q water to $100 \%$ methanol (J. T. Baker, Phillipsburg, NJ, U.S.A.) at a flow rate of $1 \mathrm{ml} / \mathrm{min}$ was applied as indicated above. A post-column split delivered approximately $25 \%$ of the flow to the mass spectrometer and the rest to the Waters 996 photodiode array detector. Mass and UV-absorption spectra of the unknown and authentic standard peaks were performed using the Masslynx Waters software.

\section{Synthesis of HCAA.}

The HCAA studied here were obtained by the reaction of $p$ coumaric and ferulic acids with tyramine and dopamine (hydrochloride form) in the presence of $N, N^{\prime}$-dicyclohexylcarbodiimide (DCC) as described elsewhere in detail (Tanaka et al. 1989). To a mixture of the corresponding hydroxycinnamic acid $(0.5 \mathrm{mmol})$ and amine $(0.65 \mathrm{mmol})$ in tetrahydrofurane (THF) $(20 \mathrm{ml})$, a solution of DCC $(0.8 \mathrm{mmol})$ in THF $(5 \mathrm{ml})$ was added, and the reaction mixture stirred overnight at room temperature. After removal of the solvent, the reaction mixture was diluted with a large volume of $\mathrm{H}_{2} \mathrm{O}$ and extracted with ethyl acetate. The organic layer was dried over $\mathrm{Na}_{2} \mathrm{SO}_{4}$ and evaporated to dryness to give viscous oil, which was purified by a column of flash 60 silica gel $(0.040$ to $0.0063 \mathrm{~mm}$; Merck, Amsterdam) with a mixture of dichlorometane/ethyl acetate $(1: 1)$ as the mobile phase to obtain the resultant transamide. The identity of the product was checked by ${ }^{1} \mathrm{H}-\mathrm{NMR}$ (proton nuclear magnetic resonance) spectra. All the synthetic compounds were identical to natural products as judged by comparison of their retention times in the HPLC chromatograms as well as UV and MS.

\section{RT-PCR.}

RNA from control and $P$. syringae-infected tomato plants or leaves treated with ethylene at $50 \mu \mathrm{l} /$ liter or $1 \mathrm{mM} \mathrm{AVG}$ were prepared using the TRIZOL reagent (Gibco BRL, Gaithersburg, MD, U.S.A.). P. syringae-infected material $(0.5 \mathrm{~g})$ was collected at the specified times (h) after inoculation. Ethylene-treated leaves were collected $24 \mathrm{~h}$ after the treatment. Total RNA (10 $\mu \mathrm{g})$ was reverse-transcribed with $100 \mathrm{U}$ of M-MLV reverse transcriptase (Promega, Madison, WI, U.S.A.) at $37^{\circ} \mathrm{C}$ for 60 min in a final volume of $50 \mu \mathrm{l}$, using a 18 -mer oligo (dT) as a primer. Reverse-transcribed DNA $(5 \mu \mathrm{l})$ was amplified by PCR using standard procedures with the following conditions: 1 min of denaturation at $94^{\circ} \mathrm{C}$ followed by 25 cycles of $1 \mathrm{~min}$ of de- naturation at $94^{\circ} \mathrm{C}, 1 \mathrm{~min}$ of annealing at $55^{\circ} \mathrm{C}$, and $1 \mathrm{~min}$ of extension at $72^{\circ} \mathrm{C}$, finished with a final extension step of $5 \mathrm{~min}$ at $72^{\circ} \mathrm{C}$. Direct $\left(5^{\prime}\right.$-ATGGCTCCTGCTCTTGAACAAG- $\left.3^{\prime}\right)$ and reverse (5'-CTAACAGCTCCCTTTCGCCGT-3') oligonucleotides were designed to amplify a 724-bp fragment from tomato THT1-3 mRNA (Von Roepenack-Layale et al. 2003). Aliquots of $25 \mu \mathrm{l}$ of the PCR products were resolved on $1 \%$ agarose gels. The gels were stained with ethidium bromide and visualized under UV light. Images were taken using gel-documentation systems and quantified by using Image Gauge V4.0 software.

\section{Antimicrobial activity of CD, FD, CT, and FT.}

The test was carried according to the method of paper disk diffusion (Cole 1994). P. syringae, maintained in $80 \%$ glycerol at $-80^{\circ} \mathrm{C}$, was reactivated in $20-\mathrm{ml}$ petri dishes with a King's medium B solid medium containing $40 \mathrm{~g}$ of proteose peptone, $20 \mathrm{~g}$ of glycerol, $980 \mathrm{ml}$ of $\mathrm{H}_{2} \mathrm{O}, 10 \mathrm{ml}$ of $10 \% \mathrm{~K}_{2} \mathrm{HPO}_{4}$, and $10 \mathrm{ml}$ of $10 \% \mathrm{MgSO}_{4}$ and incubated for $48 \mathrm{~h}$ at $28^{\circ} \mathrm{C}$. Then, bacterial colonies were cultured in $15 \mathrm{ml}$ of Luria-Bertani medium (Pronadisa, Madrid) overnight at $28^{\circ} \mathrm{C}$. A $1-\mathrm{ml}$ culture containing approximately $10^{6} \mathrm{CFU}$ was mixed with $15 \mathrm{ml}$ of culture medium Plate Count Agar (Difco, Detroit) in a petri dish. When the medium was completely solidified, three Whatman disks (no. $113,0.5 \mathrm{~cm}$ in diameter) impregnated with different concentrations of each HCAA dissolved in $10 \mu \mathrm{l}$ of methanol were added in the Whatman disks. The plates were incubated for $24 \mathrm{~h}$ at $28^{\circ} \mathrm{C}$ in the dark in order to avoid the cis/trans isomerization of these compounds (Towers 1984). Plate Count Agar plates containing only methanol were used as control plates, and a positive control with tetracycline chlorhydrate $\left(10 \mu \mathrm{g} / \mathrm{cm}^{2}\right)$, was performed. Bactericidal activity was determined by measuring the inhibition zone developed around the paper disk, indicating a zone of no growth, and each assay was performed three times. Minimal inhibitory concentration was determined as the lowest concentration able to inhibit any visible microbial growth (Cos et al. 2006).

\section{Antioxidant activity of CT, FT, CD, and FD.}

The antioxidant activity of hydroxycinnamic acids, amines, and HCAA was evaluated using the assay based on the scavenging of the stable radical DPPH (Hirota et al.1997) as described by Alfaro and associates (2003). Ethanolic solution (2 $\mathrm{ml}$ ) containing the corresponding compounds at different concentrations was mixed with $1 \mathrm{ml}$ of $0.5 \mathrm{mM}$ DPPH (dissolved in ethanol) and $2 \mathrm{ml}$ of $0.1 \mathrm{M}$ sodium acetate ( $\mathrm{pH} 5.5)$. After incubation of the mixture at $25^{\circ} \mathrm{C}$ for $30 \mathrm{~min}$, the absorbance at $517 \mathrm{~nm}$ was measured using a JENWAY 6305 spectrophotometer. Radical scavenging activity was expressed as the concentration of product necessary to reduce to $50 \%$ the absorbance of DPPH at $517 \mathrm{~nm}$. BHT (Sigma, St. Louis) was tested as a positive control. Data of the experiments represent the mean \pm standard error of three individual samples.

\section{AVG and ethylene treatments.}

For AVG and ethylene treatments, 5-week-old tomato plants grown in the same conditions as stated above were used. Tomato plants were sprayed until run-off with $1 \mathrm{mM}$ aqueous solution of AVG and again $10 \mathrm{~h}$ later. Two hours later, the AVG-treated plants were inoculated with the bacteria. Equivalent leaflets ( 0.3 to $0.5 \mathrm{~g}$ fresh weight) from nontreated, AVG-treated, and infected plants were detached at different times to determine ethylene production and RNA preparation, and for HCAA analysis. For ethylene treatments, plants were placed during 24 $\mathrm{h}$ into 125-liter sealed containers in a conditioned chamber at $25^{\circ} \mathrm{C}$, with a photoperiod of $16 \mathrm{~h}$. A mixture of ethylene in air ( $50 \mu \mathrm{l} /$ liter) (Linde, Barcelona, Spain) was passed through the containers at a constant flow rate of 15 liters/h. 


\section{Analysis of ethylene.}

At the specific times, ethylene was measured by sealing a single equivalent leaflet ( 0.3 to $0.5 \mathrm{~g}$ fresh weight) from control, AVG-treated, and inoculated leaves into 18-ml serum flasks at $25^{\circ} \mathrm{C}$ for $2 \mathrm{~h}$. A 1-ml gas sample was withdrawn from the flask with a gas-tight syringe through the rubber seal and injected into a TRB-1 TRACER column (60-m length, 0.56$\mathrm{mm}$ interior diameter) connected to a flame-ionization detector in a 4890 Hewlett-Packard (Palo Alto, CA, U.S.A.) gas chromatograph equipped with a 3395 Hewlett-Packard integrator. The temperature of the oven was $60^{\circ} \mathrm{C}$ and retention time of ethylene was $0.98 \mathrm{~min}$. Ethylene production by the samples was calculated as the mean of at least three independent incubations using an ethylene standard curve.

\section{ACKNOWLEDGMENTS}

This work was supported by Grant BMC2000-1136 from Comisión Interministerial de Ciencia y Tecnología, Spanish Ministry of Science and Technology. L. Zacarés was supported by a fellowship CTBPRB/2003/112 from Generalitat Valenciana, Conselleria de Empresa, Universidad y Ciencia, Spain. We gratefully acknowledge J. D. G. Jones (John Innes Centre, Norwich, U.K.) for the gift of seed of the transgenic NahG tomato plants and L. Yenush for critical reading of the manuscript and helpful discussions. I. Rodrigo is acknowledged for his continuous support during the course of this project.

\section{LITERATURE CITED}

Adams, D. O., and Yang, S. F. 1979. Ethylene biosynthesis: Identification of 1-aminocyclopropane1-1carboxylic acid as an intermediate in the conversion of methionine to ethylene. Proc. Natl. Acad. Sci. U.S.A. 76:170-174.

Alfaro, C., Urios, A., González, M. C., Moya, P., and Blanco, M. 2003. Screening for metabolites from Penicillium novae-zeelandiae displaying radical-scavenging activity and oxidative mutagenicity: Isolation of gentisyl alcohol. Mutat. Res. 539:187-194.

Bellés, J. M., Garro, R., Fayos, J., Navarro, P., Primo, J., and Conejero, V. 1999. Gentisic acid as a pathogen-inducible signal, additional to salicylic acid for activation of plant defenses in tomato. Mol. PlantMicrobe Interact. 12:227-235.

Bellés, J. M., Garro, R., Pallás, V., Fayos, J., Rodrigo, I., and Conejero, V. 2006. Accumulation of gentisic acid as associated with systemic infections but not with the hypersensitive response in plant-pathogen interactions. Planta 223:500-511.

Boller, T. 1990. Ethylene and plant-pathogen interactions. Pages 138-145 in: Polyamine and Ethylene: Biochemistry, Physiology, and Interactions. H. E. Flores, R. N. Arteca, and J. C. Shannon, eds. American Society of Plant Physiologists, Rockville, MD, U.S.A.

Brading, P. A., Hammond-Kosack, K. E., Parr, A., and Jones, J. D. G. 2000. Salicylic acid is not required for $C f-2$ and $C f$-9-dependent resistance of tomato to Cladosporium fulvum. Plant J. 23:305-318.

Ciardi, J. A., Tieman, D. M., Lund, S. T., Jones, J. B., Stall, R. E., and Klee, H. J. 2000. Response to Xanthomonas campestris pv. vesicatoria in tomato involves regulation of ethylene receptor gene expression. Plant Physiol. 113:81-92.

Cole, M. D. 1994. Key antifungal, antibacterial and anti-insect assays-a critical review. Biochem. Syst. Ecol. 22:837-856.

Collinge, D. B., Milligan, D. E., Dow, M., Scofield, G., and Daniels, M. 1987. Gene expression in Brassica campestris showing a hypersensitive response to the incompatible pathogen Xanthomonas campestris pv. vitians. Plant Mol. Biol. 8:405-414.

Conejero, V., Bellés, J. M., García-Breijo, F., Garro, R., Hernández-Yago, J., Rodrigo, I., and Vera, P. 1990. Signaling in viroid pathogeneis. Pages 233-261 in: Recognition and Response in Plant-Virus Interactions. R.S.S. Fraser, ed. Springer Verlag, Berlin-Heidelberg.

Cos, P., Rajan, P., Vedernikova, I., Calomme, M., Pieters, L., Vlietinck, A.J., Augustyns, K., Haemers, A., and Vander Berghe, D. 2002. In vitro antioxidant profile of phenolic acid derivatives. Free Rad. Res. 36:711-716.

Cos P., Vlietinck, A. J., Berghe, D. V., and Maes, L. 2006. Anti-infective potential of natural products: How to develop a stronger in vivo 'proofof-concept'. J. Ethnopharmacol. 106:290-302.

Dangl, J. L. and Jones, J. D. G. 2001. Plant pathogens and integrated defense responses to infection. Nature 411:826-833.

Delaney, T. P., Uknes, S., Vernooij, B., Friedrich, L., Weymann, K., Negrotto, D., Gaffney, T., Gut-Rella, M., Kessmann, H., Ward, E., and
Ryals, J. 1994. A central role of salicylic acid in plant disease resistance. Science 266:1247-1250.

Dempsey, D. A., Shah, J., and Klessig, D. F. 1999. Salicylic acid and disease resistance in plants. Crit. Rev. Plant Sci. 18:547-575.

Díaz, J., ten Have, A., and van Kan, J. A. L. 2002. The role of ethylene and wound signaling in resistance of tomato to Botrytis cinerea. Plant Physiol. 129:1341-1351.

Dixon, R. A. 1999. Isoflavonoids: Biochemistry, molecular biology and biological functions. Pages 773-823 in: Comprehensive Natural Products Chemistry, Vol. 1. U. Sankawa, ed. Elsevier, New York.

Dixon, R. A. 2001. Natural products and plant disease resistance. Nature 411:843-847.

Dixon, R. A., Harrison, J. J., and Lamb, C. J. 1994. Early events in the activation of plant defense responses. Annu. Rev. Phytopathol. 32:479501.

Dixon, R. A., Achnine, L., Kota, P., Liu, C.-J., Srinivasa Reddy, M. S., and Wang, L. 2002. The phenylpropanoid pathway-a genomic perspective. Mol. Plant Pathol. 3:371-390.

Facchini, P. J., Hagel, J., and Zulak, K. G. 2002. Hydroxycinnamic acid amide metabolism: Physiology and biochemistry. Can J. Bot. 80:577589.

Fayos, J., Bellés, J. M., López-Gresa, M. P., Primo, J., and Conejero, V. 2006 . Induction of gentisic acid 5- $O$ - $\beta$-D-xylopyranoside in tomato and cucumber plants infected by different pathogens. Phytochemistry 67:142-148.

Grandmaison, J., Olah, G. M., Van Calsteren, M. R., and Furlan, V. 1993. Characterization and localization of plant phenolics likely involved in the pathogen resistance expressed by endo-mycorrhizal roots. Mycorrhiza 3:155-164.

Guillet, G., and De Luca, V. 2005. Wound-inducible biosynthesis of phytoalexin hydroxycinnamic acid amides of tyramine in tryptophan and tyrosine decarboxylase transgenic tobacco lines. Plant Physiol. 137:692-699.

Hagel, J. M., and Facchini, P. J. 2005. Elevated tyrosine decarboxylase and tyramine hydroxycinnamoyltransferase levels increased wound-induced tyramine-derived hydroxycinnamic acid amide accumulation in transgenic tobacco leaves. Planta 221:904-914.

Hahlbrock, K., and Scheel, D. 1989. Physiology and molecular biology of phenylpropanoid metabolism. Annu. Rev. Plant Physiol. Plant Mol. Biol. 40:347-369.

Hammerschmidt, R. 1999. Phytoalexins: What have we learned after 60 years? Annu. Rev. Phytopathol. 37:285-306.

Harborne, J. B. 1980. Plant phenolics. Pages 329-402 in: Secondary Plant Products, New Series, Vol. 8. E. A. Bell and B. V. Charlwood, eds. Springer, New York.

Hirota, A., Morimitsu, Y., and Hojo, H. 1997. New antioxidative indophenol-reducing phenol compounds isolated from Mortierella sp. fungus. Biosci. Biotechnol. Biochem. 61:647-650.

Ishihara, A., Kawata, N., Matsukawa, T., and Iwamura, H. 2000. Induction of $N$-hydroxycinnamoyltyramine synthesis and $N$-hydroxycinnamoyltransferase (THT) activity by wounding in maize leaves. Biosci. Biotechnol. Biochem. 64:1025-1031.

Jang, S.-M., Ishihara, A., and Back, K. 2004. Production of coumaroylserotonin and feruloylserotonin in transgenic rice expressing peper hydroxycinnamoyl-coenzyme A:serotonin $N$-(hydroxycinnamoyl) transferase. Plant Physiol. 135:346-356.

Keller, H., Hohlfeld, H., Wray, V., Hahlbrock, K., Scheel, D., and Strack, D. 1996. Changes in the accumulation of soluble and cell wall-bound phenolics in elicitor-treated cell suspension cultures and fungusinfected leaves of Solanum tuberosum. Phytochemistry 42:389-396.

Lund, S. T., Stall, R. E., and Klee, H. J. 1998. Ethylene regulates the susceptible response to pathogen infection in tomato. Plant Cell 10:371382 .

Matamoros, M. A., Dalton, D. A., Ramos, J., Clemente, M. R., Rubio, M. C., and Becana, M. 2003. Biochemistry and molecular biology of antioxidants in the Rhizobia-legume symbiosis. Plant Physiol. 133:499-509.

McLusky, S. R., Bennett, M. H., Beale, M. H., Lewis, M. J., Gaskin, P., and Mansfield, J. W. 1999. Cell wall alterations and localized accumulation of feruoyl-3'-methoxytyramine in onion epidermis at sites of attempted penetration by Botrytis allii are associated with actin polarisation, peroxidase activity and suppression of flavonoid biosynthesis. Plant J. 17:523-534.

Métraux, J.-P., and Raskin, I. 1993. Role of phenolics in plant disease resistance. Pages 191-209 in: Biotechnology in Plant Disease Control. Wiley-Liss, New York.

Métraux, J. P., Signer, H., Ryals, J., Ward, E., Wyss-Benz, M., Gaudin, J., Raschdorf, K., Schmid, E., Blum, W., and Iverardi, B. 1990. Increase in salicylic acid at the onset of systemic acquired resistance in cucumber. Science 250:1004-1006.

Naranjo, M. A., Romero, C., Bellés, J. M., Montesinos, C., Vicente, O., 
and Serrano, R. 2003. Lithium treatment induces a hypersensitive-like response in tobacco. Planta 217:417-424.

Nawrath, C., and Métraux, J. P. 1999. Salicylic acid induction-deficient mutants of Arabidopsis express $P R-2$ and $P R-5$ and accumulate high levels of camalexin after pathogen induction. Plant Cell 11:1393-1404.

Negrel, J., and Javelle, F. 1997. Purification, characterization, and partial amino acid sequencing of hydroxycinnamoyl-CoA:tyramine $N$-(hydroxycinnamoyl) transferase from tobacco cell-suspension cultures. Eur. J. Biochem. 247:1127-1135.

Negrel, J., and Jeandet, P. 1987. Metabolism of tyramine and feruloyltyramine in TMV inoculated leaves of Nicotiana tabacum. Phytochemistry $26: 2185-2190$.

Negrel, J., and Martin, C. 1984. The biosynthesis of feruloyltyramine in Nicotiana tabacum. Phytochemistry 23:2798-2801.

Negrel, J., Javelle, F., and Paynot, M. 1993. Wound-induced tyramine hydroxycinnamoyl transferase in potato (Solanum tuberosum) tuber discs. J. Plant Physiol. 142:518-524.

Negrel, J., Lotfy, S., and Javelle, F. 1995. Modulation of the activity of two hydroxycinnamoyltransferases in wound-healing potato tuber discs in response to pectinase and abscisic acid. J. Plant Physiol. 146:318-322.

Newman, M. A., Von Roepenack-Lahaye, E., Parr, A., Daniels, M. J., and Dow, J. M. 2001. Induction of hydroxycinnamoyl-tyramine conjugates in pepper by Xanthomonas campestris, a plant defense response activated by $h r p$ gene-dependent and hrp gene-independent mechanisms. Mol. Plant-Microbe Interact. 14:785-792.

Niehl, A., Lacomme, C., Erban, A., Kopka, J., Krämer, U., and Fisahn, J. 2006. Systemic potato virus $X$ infection induces defence gene expression and accumulation of $\beta$-phenylethylalanine-alkaloids in potato. Funct. Plant Biol. 33:593-604.

Niggeweg, R., Michael, A. J., and Martin, C. 2004. Engineering plants with increased levels of the antioxidant chlorogenic acid. Nat. Biotechnol. 22:746-754.

Pearce, G., Marchand, P. A., Griswold, J., Lewis, N. G., and Ryan, C. A. 1998. Accumulation of feruloyltyramine and $p$-coumaroyltyramine in tomato leaves in response to wounding. Phytochemistry 47:659-664.

Reinhardt, D., Wiemken, A., and Boller, T. 1991. Induction of ethylene biosynthesis in compatible and incompatible interactions of soybean roots with Phytophthora megasperma f. sp. glycinea and its relation to phytoalexin accumulation. J. Plant Physiol. 138:394-399.

Schmidt, A., Scheel, D., and Strack, D. 1998. Elicitor-stimulated biosynthesis of hydroxycinnamoyltyramines in cell suspension cultures of Solanum tuberosum. Planta 205:51-55.

Schmidt, A., Grimms, R., Schmidt, J., Scheel, D., Strack, D., and Rosahl,
S. 1999. Cloning and expression of a potato cDNA encoding hydroxycinnamoyl-CoA:tyramine $N$-(hydroxycinnamoyl) transferase. J. Biol. Chem. 274:4273-4280.

Sticher, L., Mauch-Mani, B., and Métraux, J.-P. 1997. Systemic acquired resistance. Annu. Rev. Phytopathol. 35:235-270.

Strack, D. 1997. Phenolic metabolism. Pages 387-416 in: Plant Biochemistry. P. M. Dey and J. B. Harborne, eds. Academic Press, London.

Tanaka, H., Nakamura, T., Ichino, K., and Ito, K. 1989. A phenolic amide from Actinodaphne longifolia. Phytochemistry 28:2516-2517.

Tanaka, E., Tanaka, C., Mori, N., Kuwahara, Y., and Tsuda, M. 2003. Phenylpropanoid amides of serotonin accumulate in witches' broom diseased bamboo. Phytochemistry 64:965-969.

Thomma, B. P. H. J., Nelissen, I., Eggermont, K., and Broekaert, W. F. 1999. Deficiency in phytoalexin production causes enhanced susceptibility of Arabidopsis thaliana to the fungus Alternaria brassicicola. Plant J. 19:163-171.

Towers, G. H. N. 1984. Interactions of light with phytochemicals in some natural and novel systems. Can. J. Bot. 62:2900-2911.

Van Kan, J. A. L., Joosten, M. H. A. J., Wagemakers, C. A. M., van den Berg-Velthuis, G. C. M., and de Wit, P. J. G. M. 1992. Differential accumulation of mRNAs encoding extracellular and intracellular PR proteins in tomato induced by virulent and avirulent races of Cladosporium fulvum. Plant Mol. Biol. 20:513-527.

Van Kan, J. A. L., Cozijnsen, T., Danhash, N., and de Wit, P. J. G. M. 1995. Induction of tomato stress protein mRNAs by ethephon, 2,6dichloroisonicotinic acid and salicylate. Plant Mol. Biol. 27:1025-1213.

Van Loon, L. C., Geraats, B. P., and Linthorst, H. J. 2006a. Ethylene as a modulator of disease resistance in plants. Trends Plant Sci. 11:184-191.

Van Loon, L. C., Rep, M., and Pieterse, C. M. 2006b. Significance of inducible defense-related proteins in infected plants. Annu. Rev. Phytopathol. 44:135-162.

Verberne, M. C., Verpoorte, R., Bol, J. F., Mercado-Blanco, J., and Linthorst, H. J. 2000. Overproduction of salicylic acid in plants by bacterial transgenes enhances pathogen resistance. Nat. Biotechnol. 18:779-783.

Von Roepenack-Lahaye, E., Newman, M. A., Schornack, S., HammondKosack, K. E., Lahaye, T., Jones, J. D. G., Daniels, M. J., and Dow, J. M. 2003. p-Coumaroylnoradrenaline, a novel plant metabolite implicated in tomato defense against pathogens. J. Biol. Chem. 278:4337343383.

Zhang, H. L., Nagatsu, A., and Sakakibara, J. 1996. Antioxidative compounds isolated from Safflower (Carthamus tinctorius L.) oil cake. Chem. Pharm. Bull. 44:874-876. 
